Protecting the Industrial Designs of Today and the Future

BY

\title{
VLADIMIR SAMOYLOV
}

\begin{abstract}
A thesis
Submitted to the Victoria University of Wellington in fulfilment of the requirements for the degree of Doctor of Philosophy
\end{abstract}

Victoria University of Wellington

2020 
This dissertation is dedicated to my father, Alexander Vladimirovich Samoylov, a man who led by example, advised and encouraged me in all my endeavours. You will never cease to inspire me. 


\section{Acknowledgments}

First and foremost, I would like to extend my gratitude to my two supervisors: Associate Professor Susan Corbett and Dr Jonathan Barrett, without whom this dissertation would have never come to be. Your specialist guidance, mentorship as well as general encouragement, was and always will be, most appreciated. Due to your patience and combined efforts, I am today a much more confident researcher and writer than I ever imagined myself becoming.

Thank you both also for introducing me to the world of academia. More specifically, for always challenging me and encouraging me to take my research as far as possible. I am also extremely appreciative of, and grateful for, the many research and teaching opportunities you have provided me alongside my $\mathrm{PhD}$ studies.

Thank you also to Professor John Creedy for your help with finalising this dissertation. I am very grateful for your advice and suggestions, which helped me improve my writing.

I would also like to thank Dr Jessica Lai and Dr Amanda Reilly, as well as the other academics at the University who contributed to my academic development by providing me with tutoring and other related opportunities, whilst I underwent my $\mathrm{PhD}$ studies. I am very glad to have got to know you and it has been a great learning experience working with you. Thank you for your faith in me.

I would also like to thank all those who participated in my research project. Thank you for giving me your time and for your most valuable contributions to this dissertation.

Last, but certainly not least, I would like to thank my mum and sisters for your unconditional love and belief in me. I am always most grateful for your support, even if I don't always make that very evident. 


\begin{abstract}
This study examines and critiques New Zealand intellectual property protection for industrial designs, taking into account that many New Zealand industrial design owners outsource manufacture of their designs to China.

Industrial design, which refers to improving the aesthetics of products to increase their marketability, is evolving conceptually and practically. In New Zealand, copyright and registered design laws each protect, respectively, the visual expression and the "eye appeal" of an original design. As design practices evolve with advances in technology however, it is increasingly evident that industrial design is about more than just visual expression or "eye appeal". Many designers are not focusing solely on product stylisation and decoration, but on the provision of a more holistic product experience for the consumer.
\end{abstract}

The development process of industrial designs from concept to marketable product is also changing, with many New Zealand industrial design owners employing increasingly efficient design development strategies. The fast-paced, cost-effective infrastructure of China is often utilised by New Zealand businesses for the manufacture of industrial designs.

This study therefore sought to determine how to appropriately protect New Zealand industrial designs, in light of:

a. foreseeable advances in technology; and

b. the fact that many New Zealand industrial designs are manufactured in China.

To answer these questions, this study examined and analysed New Zealand's copyright and registered design laws, taking into account not only existing protections, but also factors that are likely to be of significant relevance in the future, such as the impact on industrial design from developments in 3D printing and virtual reality.

The Chinese intellectual property regime for industrial designs was also examined because China is a major trading partner and often, as noted, the locus of manufacture. 
The study included an empirical investigation, in the form of interviews with designers and design academics as well as legal practitioners specialising in intellectual property law. The input of the interviewees, together with the legal analysis, informed a series of suggestions and recommendations for New Zealand policy and its law-makers regarding how industrial design protection can be improved.

A key finding of this study was that existing legal protections do not appropriately protect increasingly holistic designs, as well as new types of designs emerging from developing fields such as virtual reality. In assessing the appropriateness of protection, the interests of industrial design owners were balanced against the public interest in protecting the public domain. It is suggested that to achieve equilibrium copyright law should be expanded to protect design expressions for all senses. Moreover, new categories of copyright protected works should be introduced to accommodate emerging design. The definition of design in registered design law should also be reconceptualised in order to acknowledge new types of designs and evolving design practices.

Industrial design owners who outsource manufacturing to China can protect their designs via copyright as well as design patent. However, enforcement of intellectual property protection is unsatisfactory in many areas of China. Therefore, New Zealand industrial design owners should also employ non-legal protection strategies. Interviews with successful businesses, in the course of the empirical investigation for this study, revealed that the leveraging of existing relationships of those with already established operations in China, and intentionally splitting an industrial design's component parts for manufacture among several factories in different locations, are useful strategies to employ. 


\section{Contents}

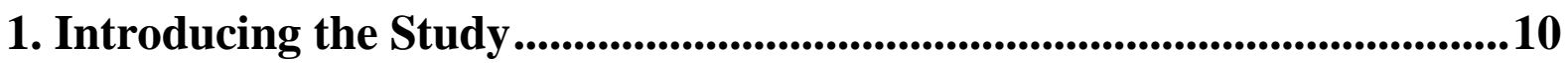

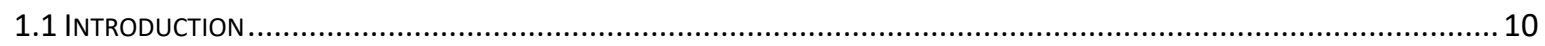

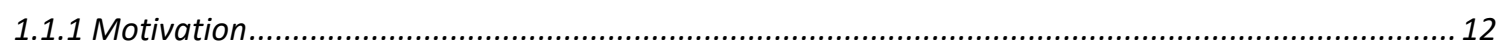

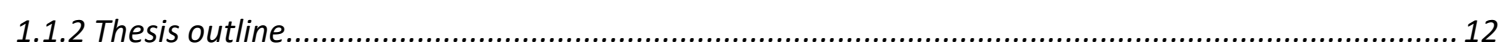

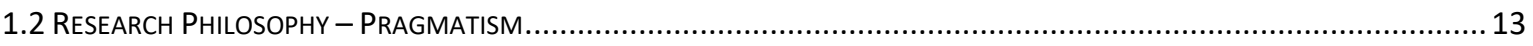

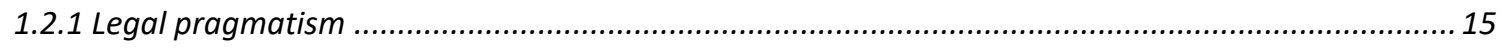

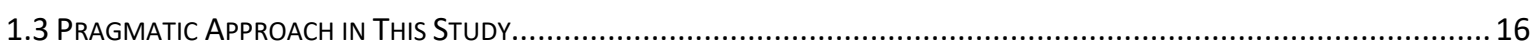

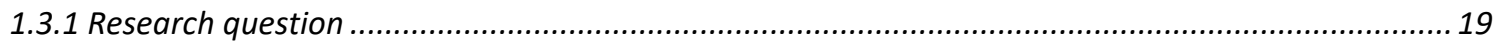

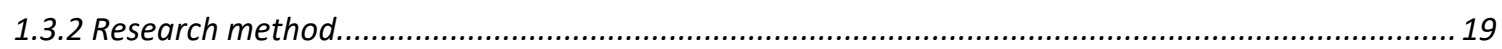

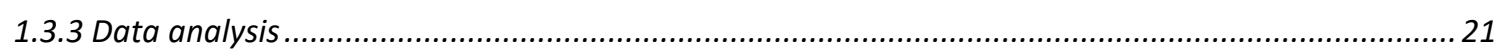

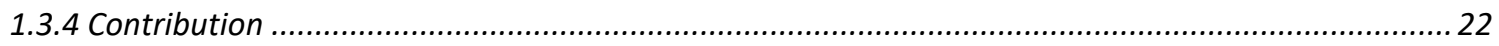

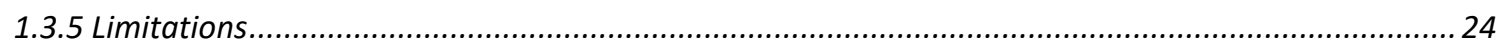

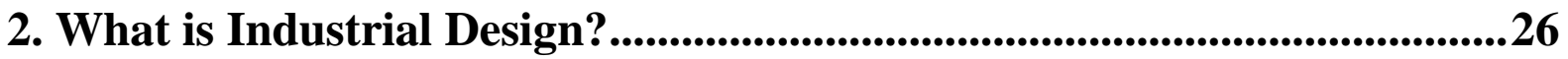

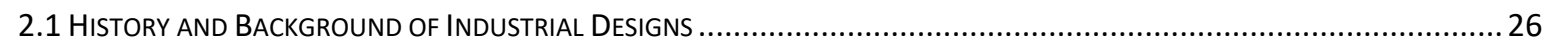

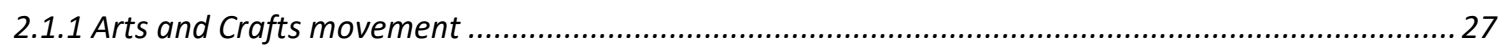

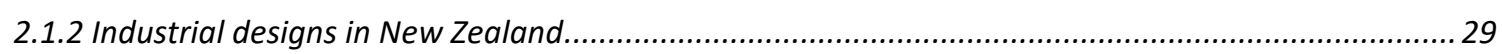

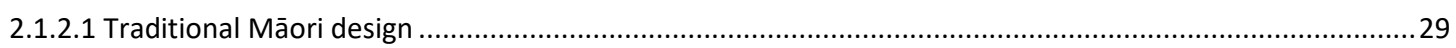

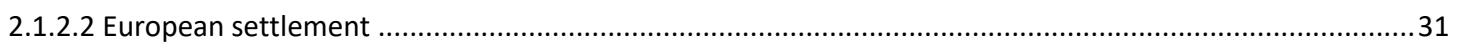

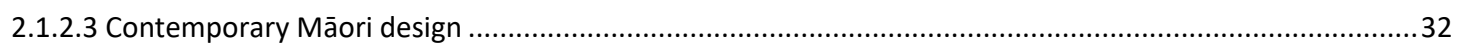

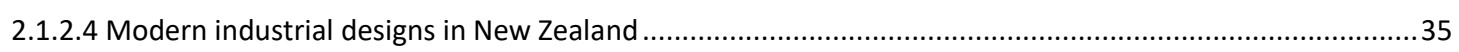

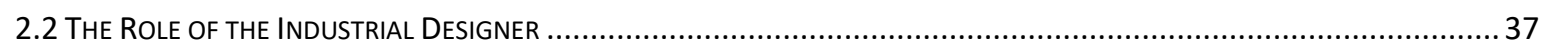

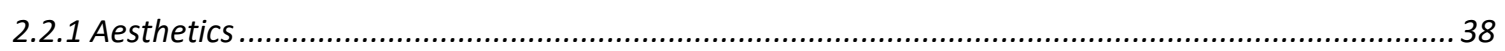

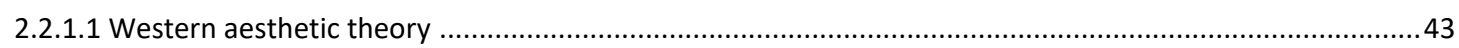

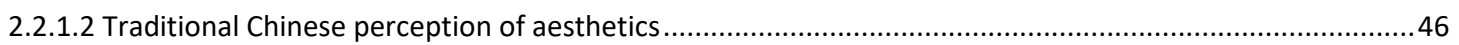

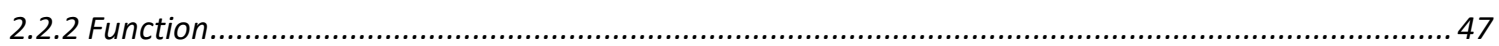

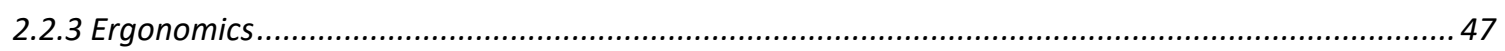

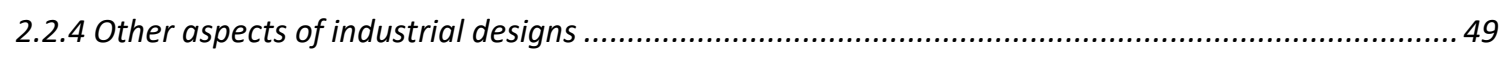

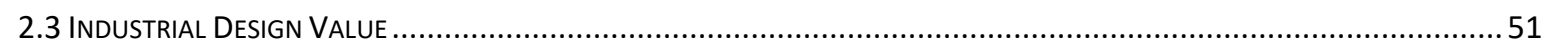

3. Legal Protection for Industrial Designs in New Zealand...........................55

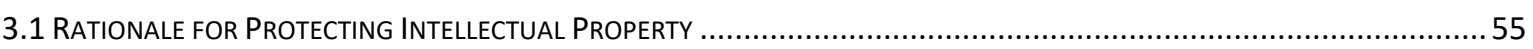

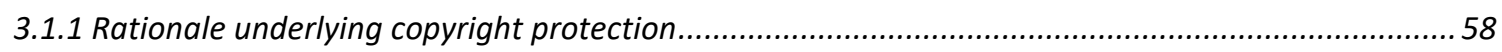

3.1.2 Rationale underlying existing protection via the registered design system ...................................... 58

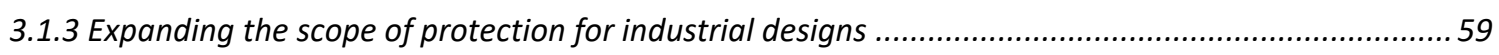

3.1.3.1 Arguments against expanding the scope of copyright ..................................................................5

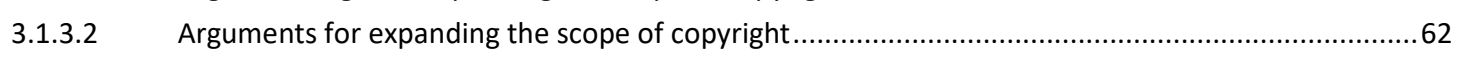

3.1.3.3 Arguments against expanding the scope of registered design law ..................................................66

3.1.3.4 Arguments for expanding the scope of registered design law .......................................................66

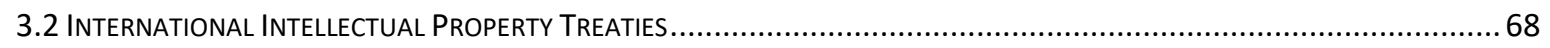

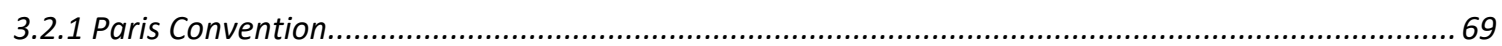

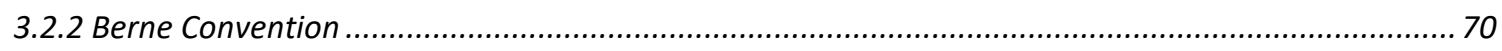

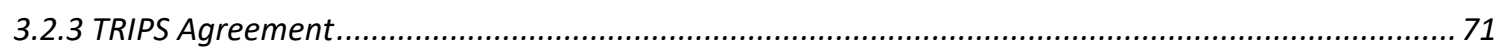


3.2.5 Comprehensive and Progressive Agreement for Trans-Pacific Partnership and the Regional

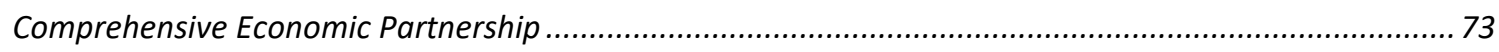

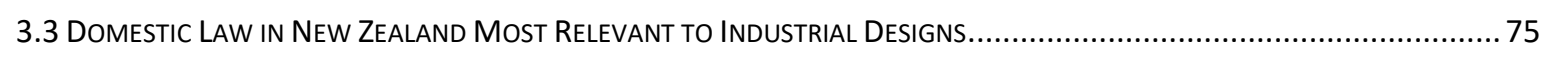

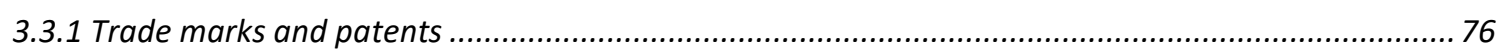

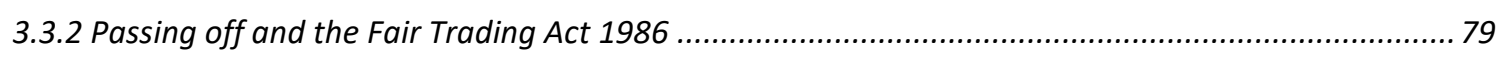

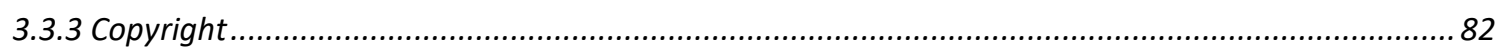

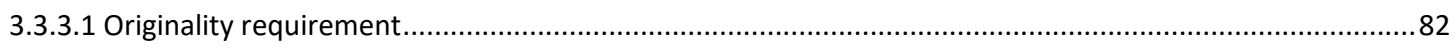

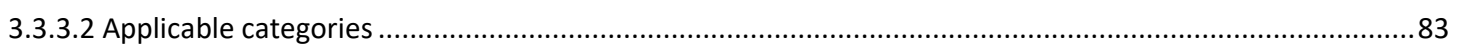

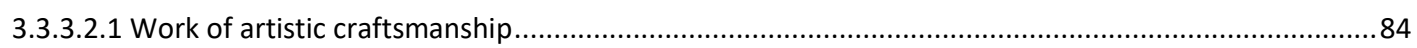

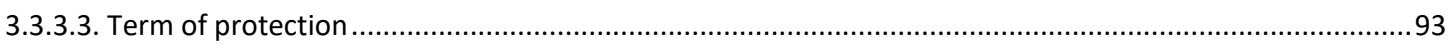

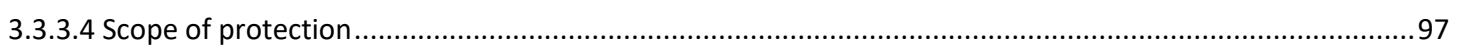

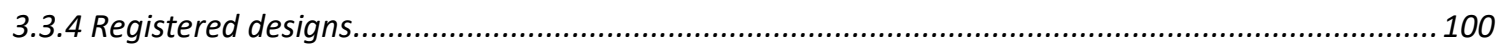

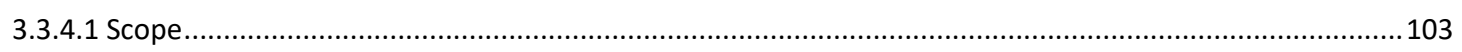

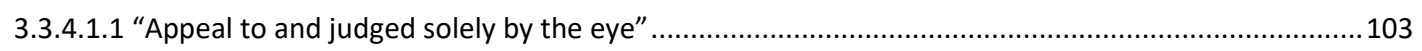

3.3.4.1.2 "Not a method or principle of construction" ................................................................................... 104

3.3.4.1.3 "Not features of shape or configuration which are dictated solely by function" ............................ 105

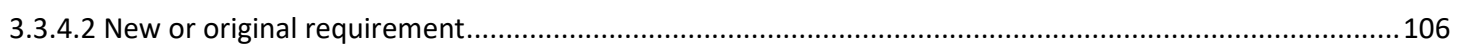

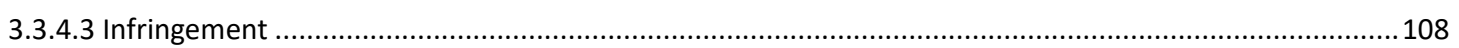

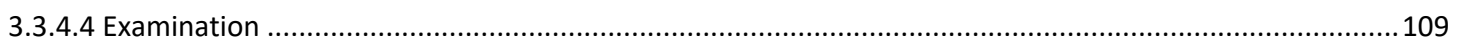

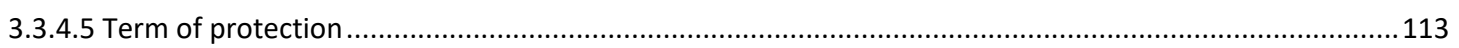

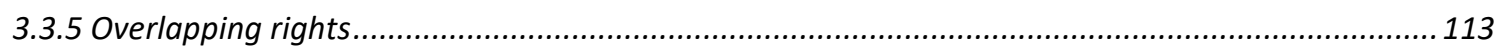

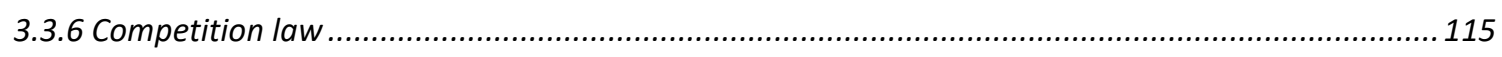

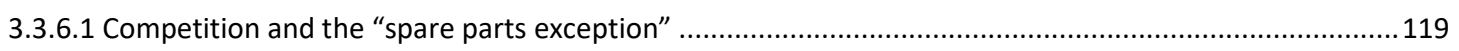

4. Legal Protection for Industrial Designs in China ....................................122

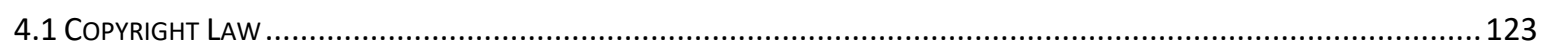

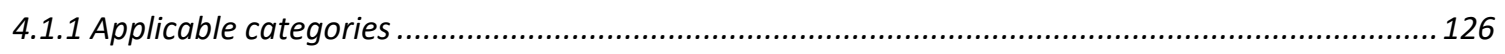

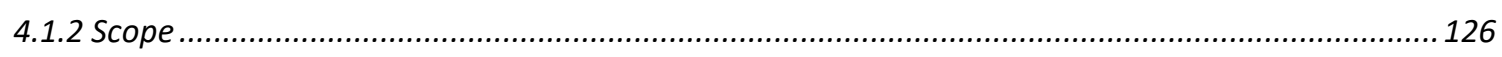

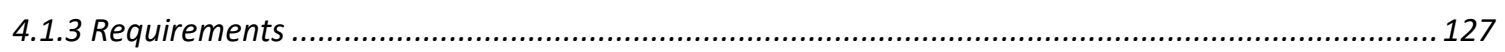

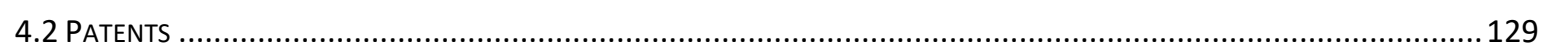

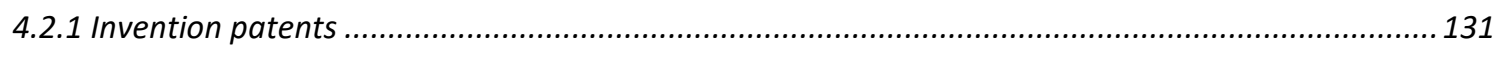

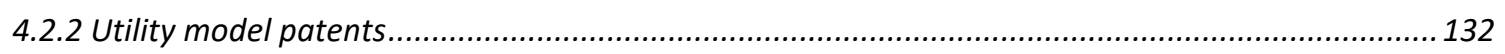

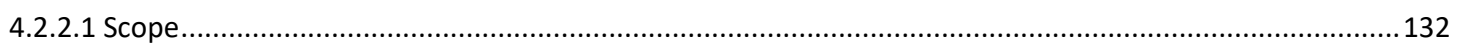

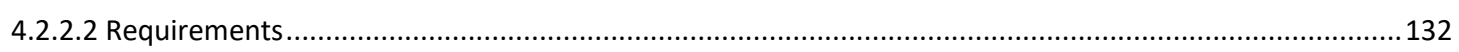

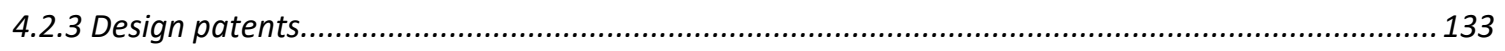

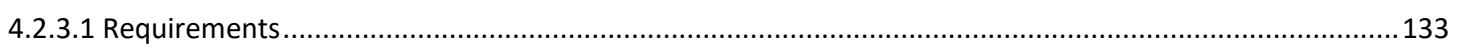

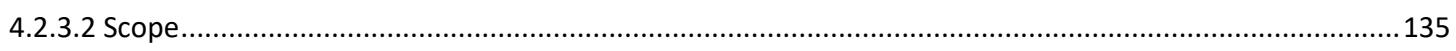

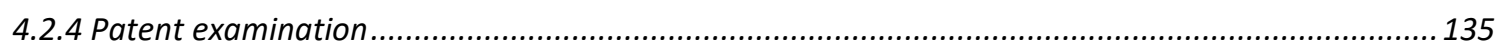

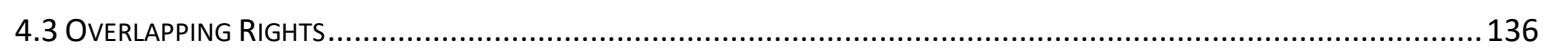

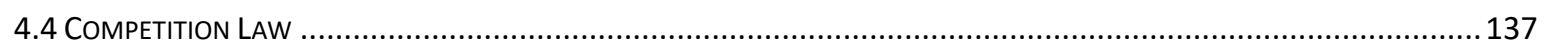

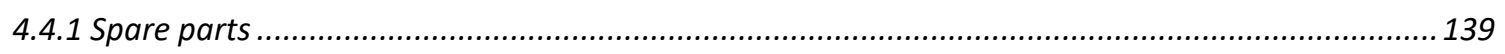

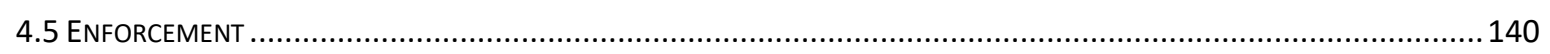

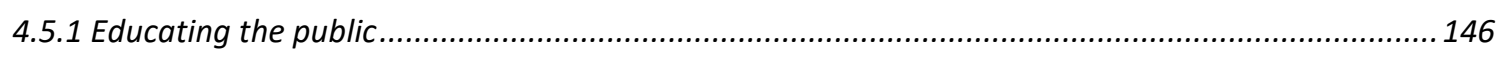

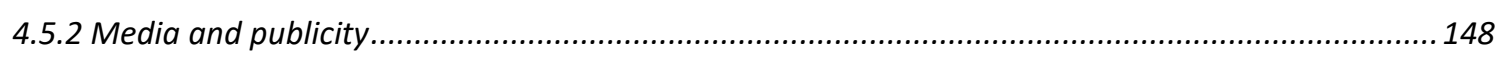

4.5.3 Accessibility to and transparency of the intellectual property legal system .................................. 148

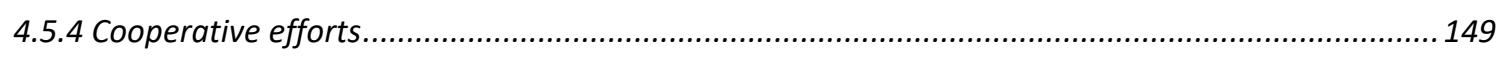




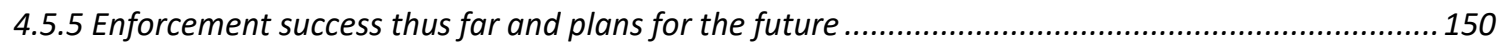

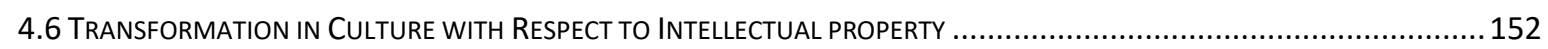

5. Impact of Advances in Technology on Industrial Design Protection .156

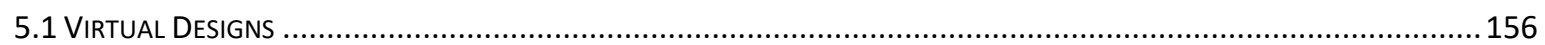

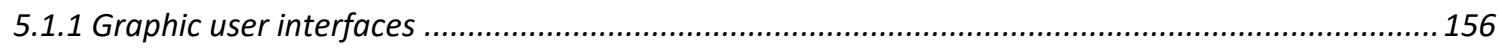

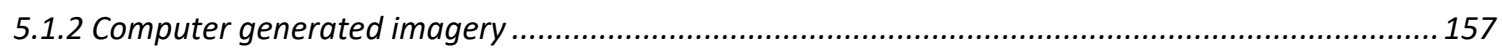

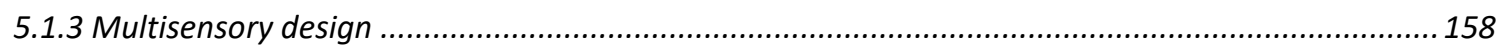

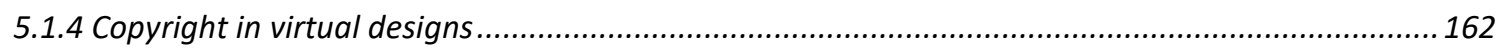

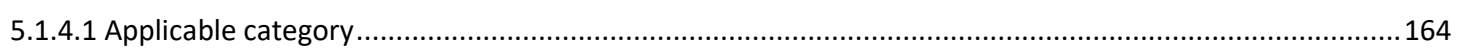

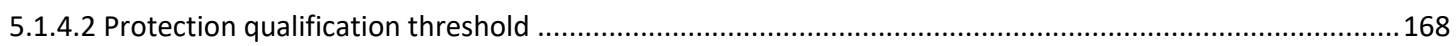

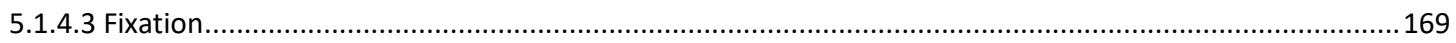

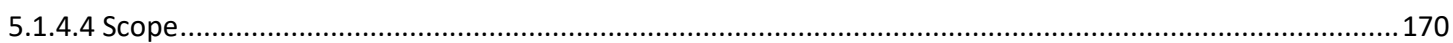

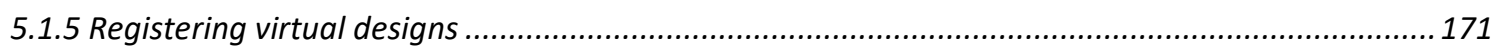

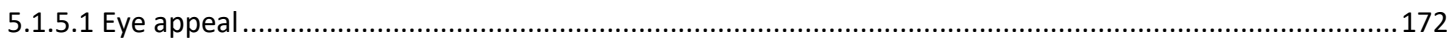

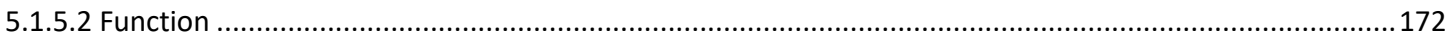

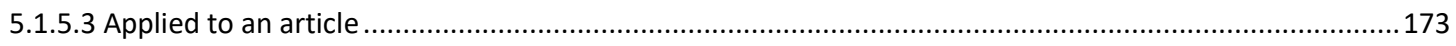

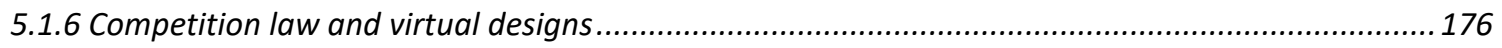

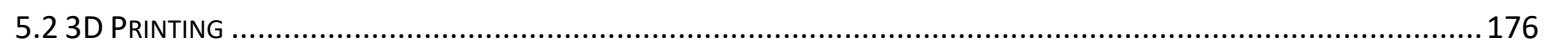

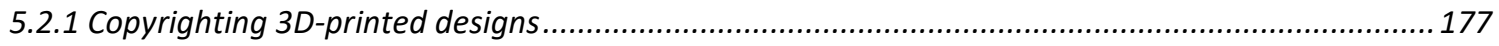

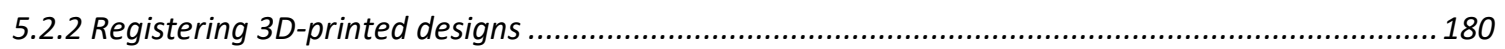

5.2.3 The impact of 3D printing on the rights of design owners and competition in the market ..............181

6. Suggestions and Recommendations in Light of Foreseeable Advances in

Technology ........................................................................................................................187

6.1 SUgGESTIONS AND RECOMMENDATIONS WITH RESPECT TO COPYRIGHT .............................................................. 190

6.1.1 Protection of non-visual/auditory expression .................................................................... 190

6.1.1.1 Can non-visual/auditory aspects of industrial design comprise original expression? ................................190

6.1.1.2 Is non-visual/auditory expression protected under copyright? ............................................................. 193

6.1.1.3 Should non-visual/auditory expression be protected? ......................................................................201

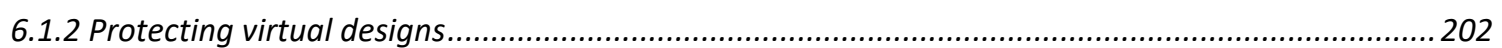

6.1.3 Determining originality in cases of multisensory designs ........................................................208

6.1.4 Applicability of the "work of artistic craftsmanship" classification...............................................212

6.2 SUgGESTIONS AND ReCOMMENDATIONS WITH RESPECT TO REGISTERED DESIGNS ..................................................218

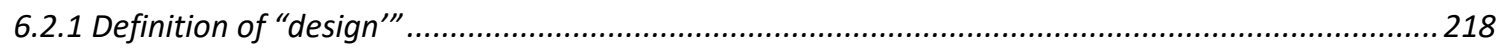

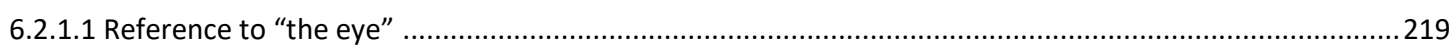

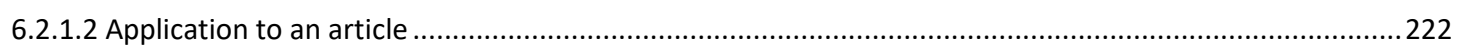

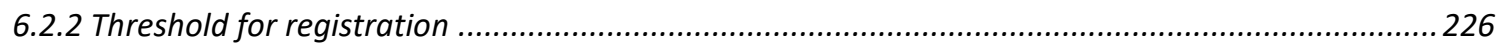

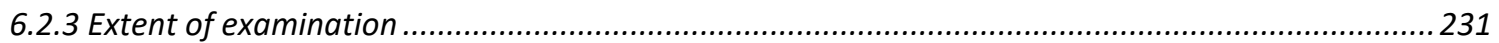

6.2.4 Adequacy of New Zealand design register ........................................................................... 232

6.2.5 Acceding to the Hague Agreement (international design register)................................................234

6.3 Suggestions And Recommendations With ReSPeCt to Industrial Design Protection Generally ......................238

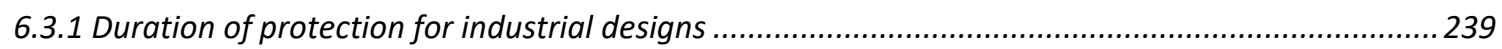

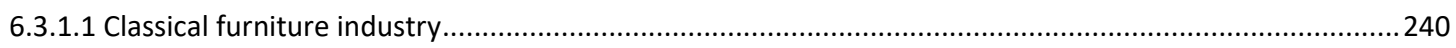

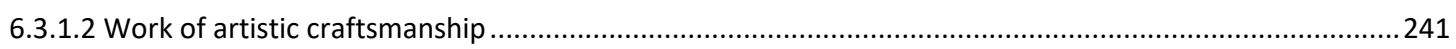

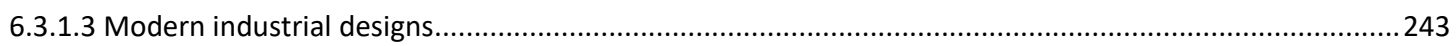




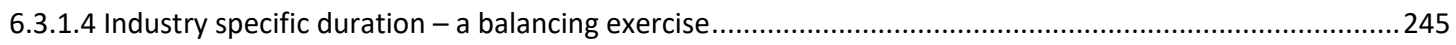

6.3.1.4.1 Arguments against expanding the scope of protection .............................................................246

6.3.1.4.2 Arguments for expanding the scope of protection....................................................................247

6.3.2 Usefulness of a "spare parts exception"..................................................................................... 251

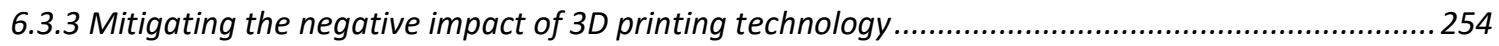

7. Suggestions and Recommendations in Light of Obstacles New Zealand

Industrial Design Owners can Expect to Encounter in China .....................260

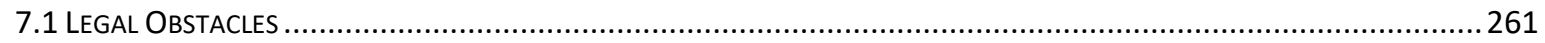

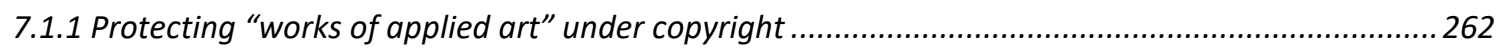

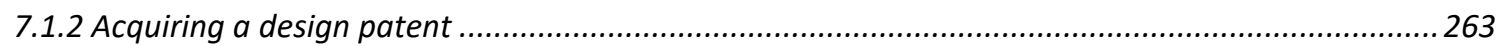

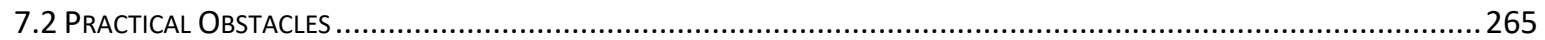

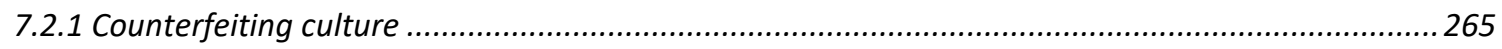

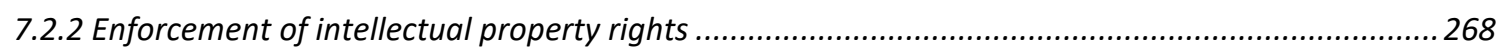

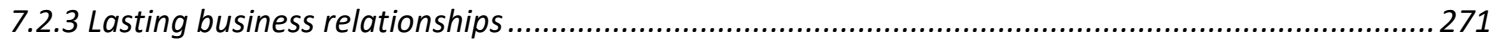

8. Bibliography ........................................................................................................275

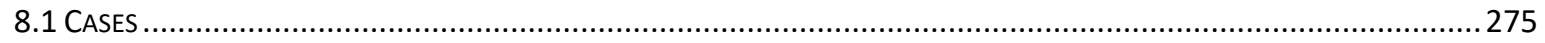

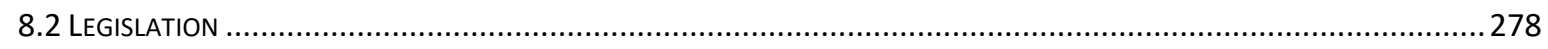

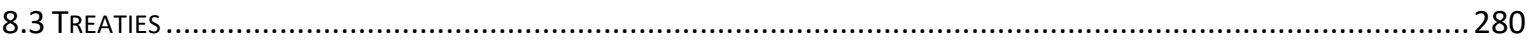

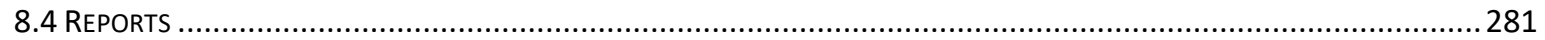

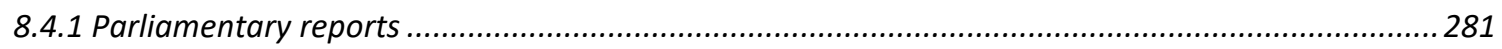

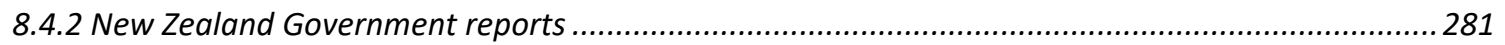

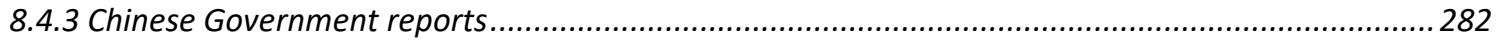

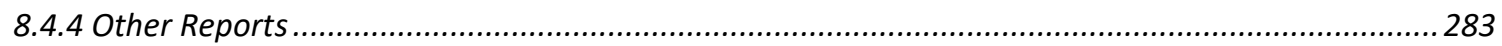

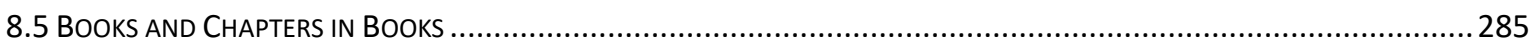

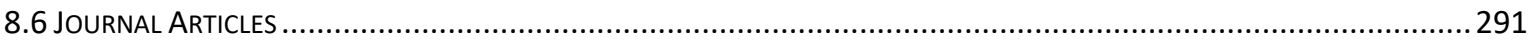

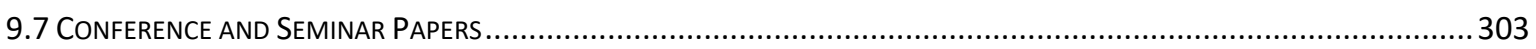

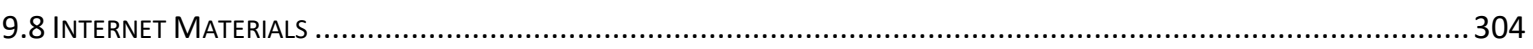

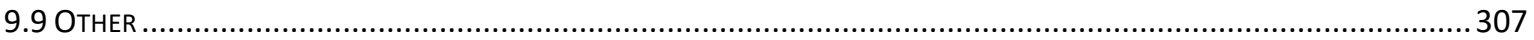




\section{Introducing the Study}

\subsection{Introduction}

Industrial design is a complex discipline that modern design law has oversimplified. Industrial design is about more than just the outward appearance of products and eye appeal. Products are designed to accommodate functional or mechanical considerations. The development of industrial designs is often informed by socially desired objectives, be they economic, ergonomic, environmental, or some other aim. ${ }^{1}$ Moreover, the advances in 3D printing and sensory technology are continually expanding the scope of possibilities for design creativity, shifting design focus from product stylisation and decoration, to the provision of a more holistic product experience for the consumer.

Despite the creative expansions of design and the fact it encompasses so many other factors, intellectual property law limits protection to the outward appearance of products. ${ }^{2}$ This study therefore examines the existing legal system in New Zealand for protecting industrial designs, and makes recommendations for policy and its law-makers as to how existing protection can be tailored to appropriately protect expanding design expression, as well as new types of designs emerging from developing fields such as virtual reality.

This study also examines the intellectual property system for protecting industrial designs in China. There is significant and increasing business potential for New Zealand in China. ${ }^{3}$ Approximately one in seven people in New Zealand is classified as an entrepreneur, which is

\footnotetext{
${ }^{1}$ Orit Afori "Reconceptualising Property in Designs" (2008) 25 Cardozo Arts \& Ent L J 1105 at 1106. For further examples of what industrial designs encompass in practice, see Section 2.2: The Role of the Industrial Designer. ${ }^{2}$ In New Zealand, this is evident in the definition of 'design' in the Designs Act 1953 (NZ). See Designs Act 1953 (NZ), s 2(1).

${ }^{3}$ Ministry of Foreign Affairs and Trade Opening Doors to China (NZ, 2015) at 8.
} 
one of the highest proportions in the world. ${ }^{4}$ Moreover, in recent years there has been a substantial increase in government initiatives, encouraging and supporting small businesses in New Zealand. ${ }^{5}$ However, New Zealand's manufacturing infrastructure and relatively small domestic market means that many New Zealand businesses must also rely on foreign markets. ${ }^{6}$ China appeals to many New Zealand businesses as an outsourcing destination. "Manufacturing is the most common scenario", a design consultancy firm (company 'A') explained. For example, one multinational company, originating in New Zealand with business operations in China (company 'B'), stated:

We have been in China for 20 years. The cost to manufacture there is reasonable. I mean it is reasonable elsewhere as well, but China is a manufacturing nation... It is also central enough for shipping pretty much everywhere in the world at the same time.

Despite its benefits, China is a risky place to expose one's industrial designs, as prior to 1980 , the Western notion of individual property rights was virtually non-existent in the Chinese legal system. Rather, in accordance with Chinese tradition and culture, intellectual property was perceived synonymously with traditional knowledge, which is not subject to individual ownership. ${ }^{7}$ Although the Chinese Government has since expended considerable effort in bringing the Chinese intellectual property system in line with international requirements, ${ }^{8}$ enforcement of intellectual property rights (at least in some parts of the country), remains unsatisfactory. Thus, in addition to identifying legal protections for protecting industrial designs in China, this study makes recommendations to New Zealand industrial design owners

\footnotetext{
${ }^{4}$ Neil Kidd Enterprise and Productivity: Harnessing Competitive Forces (New Zealand Treasury Productivity Paper, 2008) at 6.

${ }^{5}$ Ministry of Business Innovation and Employment Small Business (NZ, 2014) at 9.

${ }^{6}$ Ministry of Business, Innovation \& Employment Copyright and the Creative Sector (NZ, 2016) at 51.

${ }^{7}$ Ibid, at 106 .

${ }^{8}$ Jane Menzies and others "Intellectual Property, Business and China: Taking a Stand" (2013) 18 Deakin L Rev 89 at 91.
} 
as to non-legal practical strategies that could be employed to ensure their designs are appropriately protected in China.

\subsubsection{Motivation}

My motivation to conduct this study stems from my interest in business and law, in particular, intellectual property law. I have previously been involved in a start-up business venture as part of a Masters project, in which I was the legal specialist in a team of interdisciplinary specialists. A major part of my role involved researching intellectual property law and identifying applicable protection measures for the product concerned. Upon conclusion of that research I was not satisfied with the protection measures available for the industrial design of the product, and so I decided to investigate further.

\subsubsection{Thesis outline}

This thesis consists of seven chapters. Following this introductory chapter, Chapter 2 provides the history of industrial designs and explains the complex role of the industrial designer. It also discusses the economic value of industrial designs. Chapter 3 discusses the rationales for recognising industrial designs as a type of intellectual property worthy of legal protection, and identifies the key provisions on industrial designs in international intellectual property treaties, This is followed by an examination of the pertinent New Zealand laws. The domestic law of China pertaining to industrial designs is discussed in Chapter 4, which also includes discussion on enforcement issues in China, and explains how conflicting cultural factors are being addressed to implement a change in general public perception with respect to the intellectual property system. Chapter 5 identifies technology that is likely to have a significant impact on 
industrial design protection in the future. Chapter 6 provides suggestions and recommendations for New Zealand policy and its law makers as to how to appropriately protect industrial designs in light of foreseeable advances in technology. The final chapter provides suggestions and recommendations for how to appropriately protect New Zealand industrial designs that are manufactured in China.

Having set out the thesis outline and briefly introduced this study, this chapter now moves onto explaining the underpinning philosophy that has been adopted in this study. Following this discussion, the chapter then identifies the research questions and explains the research methods that have been employed. The chapter ends with a discussion of the contributions and limitations of the study.

\subsection{Research Philosophy - Pragmatism}

Pragmatism is the underpinning philosophy in this study. Therefore, it is discussed here, so as to give the reader some background and contextual understanding of my philosophical views, mindset and approach to research.

Pragmatism, which perceives absolute truth as an inconceivable concept due to the subjectivity of human experience, ${ }^{9}$ was established as a philosophical doctrine in the 1870 s. Charles Sanders Pierce is credited as the founder, although John Dewey and William James are also both accredited as contributors due to their significant contribution, in the twentieth century, to the development of pragmatist philosophy. ${ }^{10}$ However, the perception of truth and the nature

\footnotetext{
${ }^{9}$ Richard Ormerod “The History and Ideas of Pragmatism” (2006) 57 J Oper Res Soc 892 at 892.

${ }^{10}$ Ibid, at 893 .
} 
of reality, which underpins pragmatist philosophy, can be traced back to sceptical philosophers of classical antiquity.

Socrates argued that, as long as the immaterial soul is connected to the material body, the physical senses prevent one from uncovering the absolute truth. ${ }^{11}$ This pragmatic notion is often misconceived by those who criticise pragmatist philosophy. For example, Adam Moore perceives pragmatists as those who believe there to be no absolute truth. According to Moore, a pragmatist is somebody who argues that truth is a social construct because they believe all knowledge to be contextual, subjective and relative. ${ }^{12}$ Although pragmatists do indeed see knowledge as contextual, subjective and relative, Moore's interpretation of a pragmatic perception of truth appears somewhat skewed. A pragmatist does not see truth as a social construct. If that were the case, it would essentially mean that pragmatists believe that the sun and moon are social constructs. Pragmatists do in fact believe in absolute truth, but they see it as inconceivable in its entirety.

Furthermore, although the physical sun and moon are examples of things that are not social constructs, the vast majority of issues that concern society most certainly are. Our perceptions of right or wrong, our beliefs and our values are indeed influenced by culture, religion, upbringing and so forth. For example, what is considered a natural right in one culture, may be considered a sin in another.

Moreover, just because our knowledge is contextual, subjective and relative does not mean there is no point in trying to understand our reality. Richard Posner reminds us of Aristotle's

\footnotetext{
${ }^{11}$ Plato Phaedo (385 BCE) (translated ed: H Tredennick (translator) in H Tarrant (ed) The Last Days of Socrates (Penguin Classics, Harmondsworth (Middlesex, 1954)) at 65.

12 Adam Moore "Intellectual Property: Theory, Privilege, and Pragmatism" (2003) 16 Can J L \& Jurisprudence 191 at 194.
} 
teaching that there is no need to have an overarching theory of reality in order to conduct a meaningful inquiry into the unknown. Rather, we must use our practical reason, as this enables us to make observations in unchartered territories. There, we can make connections to things with which we are familiar, while using rhetoric to bridge the gaps. ${ }^{13}$

Pragmatists employ theory wherever possible, but only in so far as it is applicable. However, pragmatists are wary of using theory when exploring the unknown. They are strictly against erecting barriers in unchartered territories, because they do not want to narrow their scope of observation. ${ }^{14}$ In such circumstances, pragmatists prefer to employ less stringent theories, ${ }^{15}$ particularly those emphasising empirical investigation. ${ }^{16}$ Pragmatists, therefore, conduct such investigations utilising only guiding principles instead of set-in-stone methods. Moreover, they collaborate with others through empirical inquiry to increase their chances of better understanding the phenomenon observed.

Having provided a brief overview of pragmatist philosophy, it is now necessary to understand the place of pragmatism in the law.

\subsubsection{Legal pragmatism}

For the legal pragmatist, present, as well as future considerations, are instrumental in shaping the law. ${ }^{17}$ Thus, although the law reflects society's respect for history and its acceptance of present circumstances, it must be nevertheless sufficiently flexible to accommodate the path

\footnotetext{
${ }^{13}$ Richard Posner "Legal Pragmatism" (2004) 35 Metaphilosophy 147 at 153.

${ }^{14}$ Steven Smith "The Pursuit of Pragmatism" (1990) 100 Yale L J 409 at 430.

${ }^{15} \mathrm{Ibid}$, at 438.

${ }^{16}$ Posner, above n 13, at 152 .

17 Shyamkrishna Balganesh "The Pragmatic Incrementalism of Common Law Intellectual Property" (2010) 63 Vand L Rev 1543 at 1566.
} 
towards future ideals. ${ }^{18}$ For the pragmatist, the aim should not be to ensure that laws are consistent with some tradition of legal theory or rationale, but rather to solve existing problems ${ }^{19}$ and to predict and pre-emptively prepare for issues that could arise in the future. ${ }^{20}$ Theorising to justify law with reference to some legal tradition is seen by the pragmatists as an unproductive effort. ${ }^{21}$ As the absolute truth is unattainable, there is always too much uncertainty. Unless overly general, theory is ultimately proven wrong as circumstances inevitably change. Thus, for the legal pragmatist, productive law-making is first and foremost a policy science. ${ }^{22}$ It is about ends rather than means. However, law is not an end in itself, rather it is an instrument or a tool for achieving a desired outcome. ${ }^{23}$ For a pragmatist, a successful outcome is one that provides for different interest groups, ${ }^{24}$ and takes account of multiple social factors. ${ }^{25}$ For this reason, pragmatists focus on empirical data. ${ }^{26}$ Law that leads to the realisation of policy goals that are informed by empirical data is thus far more indicative of success than law consistent with legal theory. ${ }^{27}$

\subsection{Pragmatic Approach in This Study}

The reason I have chosen the pragmatic as opposed to the more generalisable law and economics research approach is because I, as a pragmatist researcher, am primarily concerned with solving a particular problem, rather than adhering to a particular research theory.

\footnotetext{
${ }^{18}$ Margaret Radin "Reconsidering the Rule of Law" (1989) 69 Bost U L Rev 781 at 816.

19 Thomas Cotter "Legal Pragmatism and the Law and Economics Movement" (1996) 84 Geo L J 2071 at 2078.

${ }^{20}$ Ibid, at 2072.

${ }^{21}$ Ibid, at 2078.

${ }^{22}$ Posner, above n 13, at 152.

${ }^{23}$ Robert Summers "Pragmatic Instrumentalism in Twentieth Century American Legal Thought - A Synthesis and Critique of our Dominant General Theory about Law and Its Use" (1981) 66 Cornell L Rev 861 at 882.

${ }^{24}$ Cotter, above n 19, at 2080.

${ }^{25}$ Summers, above n 23, at 891.

${ }^{26}$ Ibid, at 938 .

${ }^{27}$ Francis Maher “Common Sense and Law” (1972) 8 Melb U L Rev 587 at 588.
} 
It will become evident in the following chapter that there is significant overlap between different fields of knowledge in this study. Besides law and economics, other relevant fields include aesthetics, art, engineering and even psychology. Moreover, this study not only examines the existing industrial design system, but it also analyses the impact of future technology on industrial design protection.

On the one hand, it is arguable that most law and economics scholars are pragmatic in the sense that they tend to dislike grand theory. ${ }^{28}$ This tendency suggests that law and economics is antifoundationalist. On the other hand, the fact that the law and economics paradigm considers a very specific set of variables suggests that they adhere to a grand theory. Their focus on wealth maximisation suggests that their underpinning theory is utilitarianism. ${ }^{29}$ Thomas Cotter explains that this is not actually the case, as most law and economics theorists acknowledge other relevant social variables, which are not directly relevant to wealth maximisation. ${ }^{30}$ Although they may acknowledge these other variables, law and economics theorists tend to minimise the significance of these factors. ${ }^{31}$ So, even if their underpinning theory is not utilitarian in the strict sense, the reality is that they never stray too far from it.

In this study, other variables are clearly significant and cannot be glossed over. The law and economics paradigm also relies on a lot of assumptions, which are very rarely informed by empirical data. ${ }^{32}$ These assumptions are often highly artificial paper logic that do not take into consideration ordinary facts of life. ${ }^{33}$ For example, a basic economic assumption is that

\footnotetext{
${ }^{28}$ Cotter, above n 19, at 2072.

${ }^{29}$ Brian Fitzgerald "Theroretical Underpinning of Intellectual Property: 'I Am a Pragmatist But Theory Is My Rhetoric"” (2003) 16 Can J L \& Jurisprudence 179 at 180.

${ }^{30}$ Cotter, above n 19, at 2101.

${ }^{31}$ Ibid, at 2114.

${ }^{32}$ Ibid, at 2117.

${ }^{33}$ Maher, above n 27, at 605.
} 
consumers always act rationally. In reality, however, empirical investigations have revealed that consumers often act irrationally, and, in certain circumstances, will even choose to engage in self-destructive behaviour. ${ }^{34}$ Rather than conducting empirical investigations to account for contextual inconsistencies, law and economics theorists instead tend to spend copious amounts of time theoretically justifying artificial assumptions. ${ }^{35}$ As the context of this study consists of real issues concerning several different interest groups, theoretical assumptions alone are clearly insufficient. For the above reason, the law and economics paradigm on its own is inappropriate for this study. The paradigm's narrow scope of observation is ${ }^{36}$ however, suitable for some aspects of this study. One of the main benefits of the pragmatic research approach is that I can utilise the law and economics paradigm for these aspects, but as a pragmatist I am not restricted to the confines of the paradigm with respect to other aspects of the study. Perhaps a useful metaphor for the pragmatic approach is a web. The law and economics paradigm comprises one strand of the web. Cotter explains that the law and economics paradigm may prove to be a very thick strand as it deals with a very significant set of variables. ${ }^{37} \mathrm{Be}$ that as it may, for the pragmatist it is only one strand, nonetheless.

Instead of restricting their observations to a limited number of variables or concerning themselves with affirming theoretical assumptions, pragmatist researchers aim to achieve contextually specific goals. ${ }^{38}$ Although pragmatists see the value of theory, especially in the sense that it informs how things have been done in the past, ${ }^{39}$ their focus is on resolving realtime issues. The specific issues of this study are identified in the research questions and objectives below. In addition to real-time issues, pragmatists aim to pre-emptively prepare for

\footnotetext{
${ }^{34}$ Cotter, above n 19, at 2118.

${ }^{35}$ Ibid, at 2116.

${ }^{36} \mathrm{Ibid}$, at 2073.

${ }^{37}$ Ibid, at 2139.

${ }^{38}$ Summers, above n 23, at 868 .

${ }^{39}$ Posner, above n 13, at 152.
} 
issues that they foresee arising in the future,${ }^{40}$ and it is for this reason that the potential impact of future technological developments is discussed in Chapter 5.

\subsubsection{Research question}

This study sought to determine how to appropriately protect New Zealand industrial designs, in light of:
a. foreseeable advances in technology; and
b. the fact that many New Zealand industrial designs are manufactured in China.

The study can be broken down into the following research objectives (in sequential order):

A. Examine the existing protection system in New Zealand to determine strengths, weaknesses and scope of available protection.

B. Examine the intellectual property regime in China in terms of the letter of the law as well as legal enforcement and business practice.

C. Determine the appropriateness of the relevant intellectual property protections in light of advancements in 3D printing and sensory technology.

D. Identify the limitations in the existing industrial design protection system and propose suggestions and recommendations for more appropriate protection.

E. Provide an overview of available intellectual property protections as well practical strategic suggestions for New Zealand businesses in relation to China.

\subsubsection{Research method}

\footnotetext{
${ }^{40}$ Cotter, above n 19, at 2073.
} 
In addition to literature reviews, the study includes an empirical investigation, in the form of interviews with representatives from contextually relevant interest groups.

As law is intertwined with politics and culture, an empirical investigation by way of interviews is necessary to attain an informed understanding of contextual influences, ${ }^{41}$ on the practical application of the law.

The sample of selected interviewees is purposive. ${ }^{42}$ Interviews were conducted with representatives of major interest groups, including industrial designers and design-oriented businesses, as well as academics and legal advisors/practitioners specialising in intellectual property.

The general purpose of the interviews was to acquire information about:

1. the interviewee's perception of what an industrial design is;

2. the strengths and weaknesses of the existing industrial design protection system;

3. opinions, suggestions and/or advice with respect to the intellectual property regime and business practice in China; and

F. the appropriateness of the relevant intellectual property protections in light of advancements in 3D printing and sensory technology.

Twenty-two interviews were conducted in total. Thirteen of these were conducted in person. Five provided written responses and the rest were conducted via phone or Skype. The same general questions were asked in all interviews. Questions were sent to interviewees in advance,

\footnotetext{
41 James Bohman "How to Make a Social Science Practical: Pragmatism, Critical Social Science and Multiperspectival Theory" (2002) 31 Millen J Int Stud 499 at 505.

${ }^{42}$ Pamela Maykut and Richard Morehouse Beginning Qualitative Research: A Philosophical and Practical Guide (RoutledgeFalmer, London, 1994) at 45.
} 
if they so chose. The questions were separated into topics, and interviewees could choose the topics discussed and the order of the questions. As the interviews were conducted by me personally, I had the advantage of following up on leads that interviewees provided, by way of unanticipated but relevant discussion, or referral to other parties. ${ }^{43}$ Interview times ranged from 30 minutes to 1 hour. The average interview time was 42 minutes. The large disparity in time is reflective of the semi-structured interview method. Most interviewees were based in New Zealand. Two of the companies interviewed are, however, also based in China, and a further three outsource certain business operations there. For commercial sensitivity purposes, interviewed companies are not referred to by name, and, for the sake of consistency, the input from academics and legal practitioners/advisors is also anonymous. Although most of the legal practitioners/advisors and academics interviewed were based in New Zealand, two Chinese academics specialising in intellectual property law also participated in the study.

Those who opted to provide a written response were sent a list of questions via email. In some cases, after written responses were received, further questions were sent for clarifications and/or further details.

The above described interview process and data collection method was approved by the Victoria University of Wellington's Pipitea Human Ethics Committee. ${ }^{44}$

\subsubsection{Data analysis}

\footnotetext{
${ }^{43}$ Ibid, at 97.

${ }^{44}$ Approval number 0000023662.
} 
This study is inductive and therefore analysis was not restricted to the post-data collection period. Rather, the data was analysed as it was being collected and then continually reanalysed as new information was obtained. Input from interviewees is provided in this dissertation wherever their insight is relevant to the discussion.

Interviewees were treated as collaborators in the study. ${ }^{45}$ The ideas and concerns expressed in the interviews with respect to industrial designs informed the suggestions and recommendations, for New Zealand policy and its law makers in Chapter 6, and for New Zealand businesses interested in working in and/or with China in Chapter 7.

\subsubsection{Contribution}

This study makes a significant contribution to academic literature in New Zealand on the topic of industrial design protection. Existing literature on the topic includes the work of notable New Zealand authors such as Rob Batty and Anna Kingsbury. Both of these authors have several publications on New Zealand design law and Kingsbury has also written on harmonising design law internationally. ${ }^{46}$ Outside New Zealand, there are many publications that discuss design law in the context of general developments in intellectually property law by notable authors such as Jane Ginsburg, Sam Ricketson and Daniel Gervais, among others. ${ }^{47}$ Most of the literature criticises existing design law and this study further adds to the criticism.

\footnotetext{
${ }^{45}$ Barbara Thayer-Bacon "Pragmatism" in Penelope Peterson, Eva Baker and Barry McGaw (eds) International Encyclopaedia of Education (3rd ed, Elsevier Ltd, Philadelphia, 2010) 86 at 91.

${ }^{46}$ See Chapter 3 for reference to, and discussion of, the works of these authors.

${ }^{47}$ See Chapter 3 for reference to, and discussion of, the works of these authors.
} 
In addition to drawing on existing literature this study also contributes to the academic literature by providing insight from industrial designers and design-oriented businesses, as well as academics and legal practitioners/advisors specialising in intellectual property.

This study examines the impact of advances in technology on industrial design protection. The presence of virtual designs and their impact on society is rapidly increasing and becoming a phenomenon of interest. ${ }^{48}$ This study looks at whether such designs should be protected, and discusses how they could be protected. The rate of development in virtual reality technology also promises an unprecedented expansion of the scope of possibilities for design creativity, in terms of interaction design. Thus, as we now find ourselves on the brink of a revolutionary leap into true multisensory design, this study proposes the time has come to seriously consider legally recognising all original expression, irrespective of with which sense(s) it communicates. There are few legal specialists writing in this area. Christopher Buccafusco, is one notable author, who has written on the influence of aesthetic theory on copyright, in light of the issue of whether protection should extend to non-visual or auditory expression. Elli Cho is another notable author in this area. She proposes that multisensory expression should be protected and that a "general look and feel" test should be used to determine the parameters of the protection. ${ }^{49}$ This study further adds to the literature in this area by explaining how the "general look and feel test" could actually be applied with respect to multisensory designs. Moreover, it breaks down, in detail, how originality can be discerned in the non-visual or auditory aspects of such designs with reference to original examples and insight from individuals working in the developing field of virtual reality.

\footnotetext{
${ }^{48}$ Stephen LaValle Virtual Reality (Cambridge University Press, Cambridge, 2019) at 32.

${ }^{49}$ See Chapter 5 for reference to, and discussion of, the works of these authors.
} 
Future developments in 3D printing technology are likely to create a very real and substantial threat to all design owners. 3D printing technology may make it possible to copy and print almost any industrial design very quickly and easily. This study provides an overview of potential means for protecting against this likely future threat.

Finally, the study provides original suggestions and recommendations, informed by insight from experienced companies, for New Zealand industrial design owners manufacturing their design in China.

\subsubsection{Limitations}

This study was conducted from a pragmatist perspective. However, other ontological and epistemological research approaches could have been adopted.

The objective of this study was to determine the extent to which the law is in line with practice in the field of industrial design, and also whether changes to the law might be necessary to accommodate future developments in industrial design. The analytical focus was on the legal protections provided for the creators of industrial designs and the rationales for those

protections. It was not an objective of this study, however, to examine the processes for pursuing a cause of action in a court or other judicial body, and the potential remedies available for infringement. An examination of the litigation processes and remedies would be complex and would require a separate independent research investigation. 
This study examines literature and laws from a foreign country, with a different language and significantly different culture. Therefore, consideration for cultural perspectives and issues of translation must be taken into account.

Interviewees from China were significantly under-represented in the empirical investigation. Multinational companies aside, specialist input from China was limited to just two academics. Although interviews were also conducted with specialist legal practitioners and government advisors in New Zealand, the same was not done in China due to the inherent difficulty of making contact and organising interviews with individuals from a different country and culture. I was, however, fortunate enough to gain a scholarship to attend the 2016 International Intellectual Property Summer School at Xiamen University. Although I learned a lot about China and intellectual property, the intensity and highly regimented structure of the short programme made it impossible to approach private legal specialists and government advisors.

Representatives of companies as well as legal practitioners and advisors are often subject to non-disclosure and confidentiality agreements. Thus, it is possible that these limited the extent of information I obtained in interviews, and may obscure the complete picture of their situation. 


\section{What is Industrial Design?}

This chapter explains what an industrial design is. The discussion focuses on industrial design in the tangible sense, as opposed to an intellectual property concept. The law will be examined in subsequent chapters. The material in this chapter serves to more holistically inform the subject of the subsequent analysis. This is because the adequacy of legal protection cannot be determined without at least a basic understanding of the subject matter for which protection is sought. For this reason, the discussion in this chapter begins with general history and background of industrial designs. As the focus of this study is the protection of New Zealand industrial designs, the discussion proceeds to industrial design in New Zealand, beginning with historical designs, before progressing to modern design. As New Zealand is a bicultural country, Māori designs as well as designs originating from Europe are discussed. The next section of the chapter proceeds to the role of the industrial designer. Then, the economic value of industrial designs is explained.

\subsection{History and Background of Industrial Designs}

The earliest example of industrial designs are perhaps ancient coins. Some of the oldest coins, with minted designs, have been traced to Lydia, present day Turkey, dating around 610 BCE. ${ }^{1}$ This dissertation, however, is concerned with more recent industrial designs as a category of modern intellectual property. Indeed, the term "industrial design" is itself much more recent. Although different sources for the term have been claimed, it seems likely to have originated

\footnotetext{
${ }^{1}$ Andrew Jamieson and Amanda Burritt "Ancient Coins: Heads and Tales from Antique Lands (2011) 46 Agora 51 at 51.
} 
during the industrial revolution in the eighteenth century, as a reference to machinemanufactured designs. ${ }^{2}$

\subsubsection{Arts and Crafts movement}

Opposition to machine manufacture came by way of the Arts and Crafts movement. Traces of the movement are still arguably evident today, personified in the form of hipsters who despise generic trends, ${ }^{3}$ but it truly flourished between 1880 and 1920.

As machines increasingly took over parts of, or in some cases the whole of, the manufacturing process, it became more common for manufacturers to mass produce their products. Speed and efficiency became the main objectives for many manufacturers under the new business model. Industrial designs became generalised for the purpose of mass production. This led many to associate industrial designs with dull mass-produced products. ${ }^{4}$ Accordingly, industrial designs became to be seen by many, including influential Arts and Crafts activists such as William Morris,${ }^{5}$ as distinct from and inferior to handmade products. ${ }^{6}$ Morris advocated for the retention of the simple nineteenth-century designs (which, ironically, were well suited to even some of the earlier machines). ${ }^{7}$

\footnotetext{
${ }^{2}$ Eric Setliff "Copyright and Industrial Design: An 'Alternative Design' Alternative” (2007) 30 Colum J L \& Arts 49 at 61.

${ }^{3}$ Avery Mann "The Hipster Ideals: If Everyone Is a Hipster Can Anyone Be a Hipster” (31 October 2016) Odyssey <www.theodysseyonline.com>.

${ }^{4}$ Paula Baron "Where art meets science beauty meets utility: the strange world of industrial design protection" (1999) 18(2) Tasm U L Rev 194 at 203.

${ }^{5}$ R S Edwards "Social and Economic Aspects of Industrial Design” (1948) 97 JRSA 25 at 27.

${ }^{6}$ Baron, above n 4, at 203.

${ }^{7}$ Michael Smythe New Zealand by Design: A History of New Zealand Product Design (Godwit, Auckland, 2011) at 150 .
} 
No real opposition to mass-produced, machine-manufactured designs was evident from any portion of the Arts and Crafts movement that had migrated to New Zealand. ${ }^{8}$ The reason for this was that perception in New Zealand was driven by necessity - a common trait of new colonies. ${ }^{9}$

The fact that Morris advocated for a design style that was well suited to machines indicates that the concern of the Arts and Crafts movement was not that machines were incapable of producing quality design (even if that were true then, it is certainly not true today). ${ }^{10}$ Rather, the inferiority of machine-manufactured designs claimed by adherents of the Arts and Crafts movement had perhaps more to do with the generic nature of mass-produced designs. The fact that it meant replacing skilled labour was also a central criticism of machine manufacture. ${ }^{11}$

Before machine manufacture became prevalent, the manufacturer was also usually the designer. Therefore, the manufacturer was typically able to tailor the designs of their products to the specific preferences of individual customers. ${ }^{12}$ Historically, English law, which is the foundational law of commonwealth countries, including New Zealand, reflected the notion that designs were primarily a form of creative expression. The law sought to protect styles of individual designers, which were considered analogous to an individual's signature. ${ }^{13}$ Despite negative perceptions, however, the value of mass-produced designs was recognised by the law. The law recognised that they were valuable, despite their generic nature, as the designs

\footnotetext{
${ }^{8}$ Ibid, at 50 .

${ }^{9}$ Ibid, at 44. For further discussion on industrial designs in New Zealand - see Section 2.1.2: Industrial designs in New Zealand.

${ }^{10}$ See the discussion on modern industrial designs in Section 2.1.2.4 Modern industrial designs in New Zealand; and in Section 2.1.3.2: Modern Chinese industrial designs.

${ }^{11}$ Mark Walker "Big and Technological Unemployment: Chicken Little Versus the Economists" (2014) 23 JET

5 at 11.

${ }^{12}$ Edwards, above n 5, at 27.

${ }^{13}$ Brad Sherman and Lionel Bently The Making of Modern Intellectual Property Law: The British Experience, 1760 - 1911 (Cambridge University Press, Cambridge, 1999) at 66.
} 
effectively accommodated the utilitarian aspects of mass-produced products. Thus, since as early as 1843 , the law has protected both hand-crafted designs as well as the typically more generic designs of mass-produced products. ${ }^{14}$

\subsubsection{Industrial designs in New Zealand}

In New Zealand, the manufacture of industrial designs developed from 1840 onwards, ${ }^{15}$ some 40 years or so after Europeans began settling in the country. ${ }^{16}$ Although the exact time of arrival is a topic of debate, it is believed that the first Māori people settled in the country approximately 600 years earlier. ${ }^{17}$ Even though Māori people did not mass produce, they certainly designed utilitarian artefacts. ${ }^{18}$

\subsubsection{Traditional Māori design}

Although Māori people also appreciated the good design of utilitarian artefacts, they did not refer to it as such. Interestingly, much of what is considered 'Māori traditional art' is much more analogous to "design". ${ }^{19}$ One argument for this is that, for Māori, there was no such thing as art for the sake of art. ${ }^{20}$ However, Māori took pride in their work and thus purposeful articles were also beautifully designed. ${ }^{21}$ The notion that Māori did not create art for the sake of art, however, seems somewhat arbitrary, as there is continuing philosophical debate as to what

\footnotetext{
${ }^{14}$ Ibid, at 64.

${ }^{15}$ Ian Hunter "Manufacturing" (11 March 2010) Te Ara the Encyclopedia of New Zealand <www.teara.govt.nz> at 1 .

16 Te Ahukaramū Charles Royal "Māori" (8 February 2005) Te Ara the Encyclopedia of New Zealand <www.teara.govt.nz> at 3 .

17 Ibid, at 2.

${ }^{18}$ Smythe, above $\mathrm{n} 7$, at 15 .

${ }^{19}$ Ibid.

${ }^{20}$ Suzi Wereta "Engaging with Māori Art and Identity: A Conversation with Māori Artists in Otepoti” (2007) 1 MAI Rev 191 at 194.

${ }^{21}$ Smythe, above $\mathrm{n}$, at 20.
} 
"art" actually is. ${ }^{22}$ According to traditional Western aesthetic theory, art is something that is created for the perceptive pleasure of the so-called higher senses, namely auditory and visual. ${ }^{23}$ In other words, art is something that inspires perception independently of any physical function that serves the body. It is arguable, on the basis of this view, that early Māori did create art for the sake of art. The designs that were often carved into articles had a purpose independent of the article's utilitarian function. Such carvings often symbolised relationships and interactions with the supernatural world, often depicting ancestors and other spiritual beings. ${ }^{24}$ Thus, an argument could be made that the supernatural aspect of such carvings inspired perception that was beyond the needs and desires of the body.

Contemporary Western aesthetic theory seems to be moving away from this notion of body transcendent perception. ${ }^{25}$ Thus, from a contemporary point of view, whether Māori traditional design is art, is a matter of perspective.

Whether one perceives them as art or not, early Māori certainly had some very intricately designed industrial artefacts. For example, some fish hooks were so intricately designed that they incorporated several different materials, one example being the hook made for catching kahawai. It consisted of a sharpened bit of bone, lashed onto a wooden shaft and inlaid with bits of the colourful pāua shell. ${ }^{26}$ The overall appearance of the design was very appealing. The traditional shape of Māori fish hooks is still a popular design for necklaces today. Although visually appealing, each of the components had a practical purpose. The bone was a sturdy

\footnotetext{
${ }^{22}$ Pania Waaka "Hei tiki and issues of representation within contemporary Māori arts" (2007) 1 MAI Rev 156 at 156.

${ }^{23}$ Christopher Buccafusco "Making Sense of Intellectual Property Law" (2012) 97 Cornell L Rev 501 at 507. For further discussion, see Section 2.2.1.1: Western aesthetic theory.

${ }^{24}$ S M Mead “The Origins of Maori Art: Polynesian or Chinese?" (1975) 45 Oceania 173 at 177.

${ }^{25}$ Buccafusco, above $\mathrm{n} 23$, at 508 .

${ }^{26}$ Smythe, above $\mathrm{n} 7$, at 20.
} 
material that could be sharpened to a point fine enough to pierce a kahawai's skin, and the bits of pāua shell were inlaid, because Māori people had discovered that kahawai were attracted to shiny objects. ${ }^{27}$

Another example of a traditionally designed utilitarian artefact was the hīnaki (eel pot), which was fabricated from either a climbing fern by the name of mangemange, or alternatively from the aerial roots of kiekie. In addition to being cleverly designed to lure eels in and prevent them from getting back out, it had a very appealing visual design. ${ }^{28}$

\subsubsection{European settlement}

With the arrival of the Europeans, Māori were introduced to literally boat loads of industrial designs from Europe. Once domestic manufacturing began, products manufactured in New Zealand simply imitated industrial designs from Europe. ${ }^{29}$ During the nineteenth century, and even the earlier part of the twentieth century, New Zealand design reflected a purpose of necessity common to colonies. The purpose of manufacture was to provide what was required, and thus very little attention was attributed to design originality. ${ }^{30}$ Moreover, in this time period, New Zealand manufacturers were able to directly copy designs without necessarily obtaining consent from design owners. The primary reason why this could often be done without repercussion was New Zealand's isolation at the far end of the world. ${ }^{31}$ Until well into

\footnotetext{
27 Ibid.

${ }^{28}$ Ibid.

${ }^{29}$ William Cottrell Furniture of the New Zealand Colonial Era: An Illustrated History 1830 - 1900 (Reed, Auckland, 2006) at 368.

${ }^{30} \mathrm{Ibid}$, at 372 .

${ }^{31}$ Nancy Swarbrick "Creative life - Design and fashion" (8 February 2005) Te Ara the Encyclopedia of New Zealand <www.teara.govt.nz> at 3.
} 
the twentieth century, at least, taking legal action against manufacturers in New Zealand was too difficult, and considered by many to be hardly worthwhile. ${ }^{32}$

Although there was little industrial design originality in New Zealand during this period, there are some early examples. German settlers were seemingly the first of the Europeans to recognise the unique attributes of native timber. ${ }^{33}$ Early manufacturers such as Johann Levien and Anton Seuffert designed furniture to accentuate the unique qualities of native timber. ${ }^{34}$ Some early furniture even incorporated traditional Māori designs. ${ }^{35}$ Such designs were a sign of European admiration of Māori traditional design. ${ }^{36}$ They were also likely early examples of indigenous design exploitation, as Māori typically did not have a share in the economic gain of the manufacturers. ${ }^{37}$

\subsubsection{Contemporary Māori design}

Exploitation of Māori traditional designs for commercial gain can be said to continue to this day. The exploitation is arguably called contemporary Māori design. This seemingly bizarre notion begins to make sense once it is understood that the concept of "contemporary" is not straightforward. In the context of Māori design, "what is contemporary?" resembles the "what is art?" paradox discussed above, in complexity. The Western notion of "contemporary design" simply means "new age" or "modern" design. This basic notion, however, is not synonymous with Māori culture. Traditional Māori designs have strong culturally significant connections to

\footnotetext{
${ }^{32}$ Smythe, above $\mathrm{n} 7$, at 76.

${ }^{33}$ Cottrell, above n 29, at 95.

${ }^{34}$ Ibid.

${ }^{35} \mathrm{Ibid}$, at 375.

${ }^{36}$ Ibid, at 376.

${ }^{37}$ See Waitangi Tribunal Ko Aotearoa Tēnei: A Report into Claims Concerning New Zealand Law and Policy Affecting Māori Culture and Identity (Wai 262, 2011) vol 1 at 84.
} 
ancestors, tribal land and iwi. ${ }^{38}$ According to Jonathan Manè-Wheoki, when aspects of Māori design are taken out of this traditional context, they lose their cultural significance and thus are no longer Māori design. This is so, even when an ethnically Māori designer incorporates aspects of Māori design inconsistently with the tradition. Such a design is no longer Māori in the cultural sense. ${ }^{39}$

However, when one considers the large numbers of works over the years, by ethnically Māori artists and designers, that incorporate traditional Māori design into more abstract modern art, including works by renowned artists such as Ralph Hotere, ${ }^{40}$ it seems almost implausible to say such works are not Māori. The phenomenon can be easily explained by the historic suppression of Māori culture both legally and socially. Legal suppression occurred by way of legislation such as the Tohunga Suppression Act 1907, which made the educational and spiritual role of tohunga (priests, healers, as well as experts in other traditional Māori practices) illegal. ${ }^{41}$ Social suppression took place by way of urbanisation, religious conversion and education. ${ }^{42}$ More specifically, in the context of art and design, an example of cultural suppression by way of education was the initiative taken by Gordon Tovey in the 1950s. At that time the national supervisor of art and crafts in the Department of Education, ${ }^{43}$ Tovey oversaw the induction of Māori students. He encouraged them to incorporate traditional design into their work, without worrying about what may be considered tapu (sacred) in Māori culture, so as not to restrict their creativity. ${ }^{44}$

\footnotetext{
${ }^{38}$ Jonathan Manè-Wheoki "The Resurgence of Māori Art: Conflicts and Continuities in the Eighties" (1995) 7 Contemp Pac 1 at 13.

${ }^{39}$ Ibid.

${ }^{40} \mathrm{Ibid}$, at 8 .

${ }^{41}$ Jessica Lai Indigenous Cultural Heritage and Intellectual Property Rights: Learning from the New Zealand Experience (Springer, London, 2014) at 21.

${ }^{42}$ Ibid.

${ }^{43}$ Manè-Wheoki, above n 38, at 8 .

${ }^{44}$ Ibid, at 9 .
} 
Manè-Wheoki explains that many such ethnically Māori artists and designers are too far removed from their culture for their work to be considered Māori. Due to urbanisation, many grow up in the city and are educated in European design and art schools. Therefore, even though their features, skin tone and sometimes even accents may distinguish them as Māori in society, often they are psychologically so far removed from the culture that they will almost have no standing in any marae. ${ }^{45}$

Manè-Wheoki's views on cultural works are of course not representative of all Māori. Jessica Lai explains the difficulty of determining representation for the culture as a whole. ${ }^{46}$ There have been several examples of opposing views and conflicting claims from different Māori groups with regards to aspects of the culture. One example occurred in 2000, when the Ngāti Toa iwi (tribe) wanted to register the Ka Mate haka ('the haka'), a traditional war dance that has been used by the New Zealand All Blacks since 1905. In the course of the arguments that ensued, three separate iwi claimed the haka originated from their ancestors. ${ }^{47}$

Historical suppression of Māori culture and conflicting views of different Māori groups are major factors standing in the way of establishing a universal system for determining culturally acceptable authentic Māori design. Of course, the issue is about much more than design, for it concerns all Māori cultural works and traditional knowledge. ${ }^{48}$ Moreover, it is a geo-sociopolitical issue that is far beyond the scope of this study.

\footnotetext{
${ }^{45}$ Ibid, at 15.

${ }^{46}$ Lai, above $\mathrm{n} 41$, at 24.

${ }^{47}$ Ibid, at 26.

${ }^{48}$ This issue of derogatory or offensive use of Māori cultural works and traditional knowledge has been addressed by the Waitangi Tribunal. For a summary of the recommendations - see Wai 262, above n 37, at 99.
} 
Another important question that is outside the scope of this study, is whether traditional cultural designs and contemporary designs that are derived from traditional designs might be more appropriately protected via sui generis legislation. ${ }^{49}$

\subsubsection{Modern industrial designs in New Zealand}

Ethnic context aside, today's technology enables all kinds of industrial designs to be mass produced and indeed there are several examples of high-calibre industrial designs being produced in New Zealand, some of which are mentioned below. However, there are some who continue to criticise industrial designs. As noted above, certain types of people, such as trenddefying hipsters, dislike industrial designs because of their tendency to follow general trends. ${ }^{50}$ Such critique is often warranted: consider the common household food mixer as an example. This is a product that has been available in the market since the early twentieth century. The functional components of the food mixer have remained largely unchanged over time, yet the form in which they have been produced has changed numerous times and the differences in design have been considerable. In the course of following general trends, there have even been food mixers incorporating the aerodynamic design features of automobiles. ${ }^{51}$ Although aerodynamics is of course necessary for automobiles, it is hardly a necessary feature in a food mixer.

Thus a good modern industrial design must not merely follow general trends, and it is certainly about more than just ornamentation or decoration of products. Gerry Luhman's park bench is

\footnotetext{
${ }^{49}$ For example, Ngāti Toa Rangatira have a statutory "right of attribution" in relation to the Ka Mate haka: Haka Ka Mate Attribution Act 2014 (NZ), s 9.

${ }^{50}$ Mann, above n 3.

${ }^{51}$ Adrian Forty Objects of Desire: Design and Society since 1750 (Thames and Hudson, London, 1986) at 219.
} 
an example of a good industrial design developed in New Zealand that incorporates a much wider range of considerations. The design was borne out of a student project initiated by the Wellington City Council Parks and Reserves Department in 1967. As part of his research for the project, Luhman observed the behaviour of people on public benches. His observations revealed that once a bench is occupied by somebody, others will typically refrain from sitting on that bench, despite it being a multi-seater, so as not to intrude on another's personal space. He also noticed that benches were frequently used as a place to sleep off the Sunday hangover. ${ }^{52}$ To address these issues, Luhman's design separated the bench in the middle, with a metal bar a couple of inches long. The design worked, as the bench proved effective in being perceived as a non-intrusive multi-seater. A commemorative plaque was attached to the metal bar, which was also part of the design consideration, as it was one of the requirements of the student project. To prevent people from sleeping off their hangovers, Luhman incorporated a groove into the bench, which in addition to serving as further separation of the double seater on each side of the commemorative plaque, also dug into the back of anyone who lay on it. ${ }^{53}$ Of course, it is arguable that this feature of the design also serves as a method of social control, in that it deters homeless people from sleeping on park benches. ${ }^{54}$

David Trubridge's lighting designs are also a good example of New Zealand design ingenuity. Much more than visually appealing, these designs provide customers with a holistic experience, ${ }^{55}$ by setting a particular kind of atmosphere in a room. ${ }^{56}$ Moreover, these designs

\footnotetext{
${ }^{52}$ Smythe, above $\mathrm{n} 7$, at 208.

${ }^{53}$ Ibid, at 209.

${ }^{54}$ For examples of hostile design or the "dark side of design", see Paul Cozens "Designed features can make cities safer, but getting it wrong can be plain frightening" (2018) The Conversation <www.theconversation.com>.

${ }_{55}$ More holistic designs, specifically those that cater to senses beyond just visual or auditory, may not be adequately protected under the current legal regime - see discussion in Section 6.1.1: Protection of nonvisual/auditory expression. For discussion of whether the scope of protection should be expanded to better accommodate such designs - see Section 3.2.3: Expanding the scope of protection for industrial designs; and Section 6.3.1.4: Industry specific duration - a balancing exercise.

${ }^{56}$ Skye Rytenskild “A Sustainable Beauty: David Trubridge's Holistic Approach to Design” (14 June 2016) Decor Design <www.decordesignshow.com>.
} 
are eco-friendly, as Trubridge uses environmentally friendly materials in his designs and constantly adapts his processes to further reduce the carbon footprint of his activities. ${ }^{57}$

The above examples illustrate the multifaceted role of industrial designers. The different aspects of their role are explained below.

\subsection{The Role of the Industrial Designer}

The role of an industrial designer is multifaceted, complex and rather difficult to conceptualise precisely. One design academic (academic 'C') explained:

It is not just about bringing new ideas, new concepts and new systems into place. I think it is quite a leadership profession. So it should be about putting ideas and concepts in front of a lot of other disciplines, and forcing them to step up to the plate. So, rather than sitting back and saying, "okay, once the engineering and everything else is done, industrial design will come along, and make it look cool”, industrial design should really look at all the technology of the day, look at the problems in society, and then try to address that. Our greatest ... challenge is to make people happier, more satisfied, maybe have more fun, and have good lives.

Another design academic, who also works as an industrial designer (academic 'D'), had his own unique interpretation:

We spend a long time looking at process and a long time looking at material. What does the material really want to do? I call that the desires of materials and processes. It is more than functional. When you get a machine really sweet, it kind of hums. It is like you have made it happy. Engineers do not quite see it that way. The other thing we do, which they

57 Collin Dunn "David Trubridge: Designing with Morality" (9 December 2005) Treehugger <www.treehugger.com>. 
have no interest in, is we constantly think about people. How someone will value something. How something might feel more comfortable to someone. Really ... I think we look at the desires of people and we look at the desires of machines and process. Then, what we do is we marry the two together .... What we do is find ways of making things ... more rewarding. It is not problem solving. So that is why I use the word desire. Desire actually conjures up more of the complexity of people. So I use the word "desire" quite particularly, instead of "need".

Further insight on the role of the industrial designers came from interviewees in industry. One industrial designer from a multinational company (company 'E') stated: "It is about aesthetics, usability and user interaction". Another multinational company (company 'F') confirmed that: "All of these things are really important. Obviously functionality is very important and so is usability. Then, there is safety as well." "You have to get it all right", a design-driven company (company ' $\mathrm{G}$ ') explained, before elaborating:

Everything has got to be right for the job that the thing is designed for. The ergonomics, the function, the environmental responsibility, the use of materials, as well as the effects of those materials on the user. It is all part of it. No one is more or less important than the other. They are all criteria that you are juggling when you are doing a design.

The above quotes illustrate that an industrial designer's role is indeed broad and complex. The following sections detail some of the key aspects of the role, so as to provide further insight as to what is being appropriated when infringers free-ride. It will become evident in the discussion that the magnitude of work involved is worthy of intellectual property protection.

\subsubsection{Aesthetics}


Eye appeal is a major element of industrial design. It is also a much more complex element than may be initially apparent, for its impact is not purely visual. To illustrate this, company ' $\mathrm{G}$ ' used the following example:

If you want light in a room you can just buy a bulb and hang it from a ceiling. That will cost you five or ten dollars. So obviously we are not providing that. We provide light in a certain way, which is more than functional. If you hang your bare bulb in a room it is depressing. It is what they put in prison cells. So what we are doing is emotional. We are changing the feeling of the room, or how you feel in that room.

Another good example of the kind of intricacies that can be communicated via visual design was provided by academic ' $\mathrm{D}$ '. They stated:

I design music amplifiers .... What I try and do is I listen to the electronics engineer and I try to understand the message he wants to get across. So what beliefs did he have when he did the electronics? Why does this thing sound so remarkable? Then, I try to display those beliefs on the outside. So when people look at it, they get his feelings, about how he did the internals .... Really, I am trying to tell people what is inside.

The problem, is that beauty or "eye appeal", no matter how intricate the intention of the designer may have been, is subjective (the "eye of the beholder" cliché). This notion is consistent with the pragmatic philosophy underlying this study. Dewey's pragmatic theory on the topic was that aesthetics is a directed experience. ${ }^{58}$ It can pose a question and indicate a direction for perception. ${ }^{59}$ Precision however, is impossible as the subjectivity of individual experience means there is plurality of meaning. ${ }^{60}$ Despite the impossibility of precision, through aesthetics one is able to contemplate and process a directed experience in a manner

\footnotetext{
${ }^{58}$ Mads Folkmann The Aesthetics of Imagination in Design (MIT Press, Massachusetts, 2013) at 33.

${ }^{59}$ Ibid, at 31 .

${ }^{60}$ Ibid, at 33 .
} 
otherwise not perceivable by different means. ${ }^{61}$ Thus, aesthetics provides an indication of an intention, the success of which can only be measured by the experience of the perceiver. ${ }^{62} \mathrm{~A}$ successful aesthetic result is thus determined by the closeness of the perceiver's perception to the vision of the artist or designer. Academic 'D' explained it as such: "When somebody sees one of my products, I build up an impression and an expectation."

Given the subjectivity of the human experience, it is certainly not obvious as to how such a result can be achieved. How can a designer hope to influence a particular type of experience when people's perceptions are shaped by factors such as age, race, gender, culture, education and upbringing? With these being just a few of the many factors, the task seems impossible. However, a successful industrial designs can have general appeal. Although there is no single definitive answer to this strange paradox, over 100 years of research has provided some insight on the matter. ${ }^{63}$ Simply put, mass appeal can be achieved because our subjective preferences are nonetheless subject to a number of universal principles. The same basic principles have been observed in several studies.

One such principle is symmetric preference ${ }^{64}$ For example, people consider symmetrical faces to be more attractive. ${ }^{65}$ One explanation for this phenomenon is that symmetrical faces are a natural sign of good health, indicating, among other things, greater likelihood of fertility. ${ }^{66}$ Thus, attraction to symmetry is likely biological. According to this line of reasoning, preference

\footnotetext{
${ }^{61}$ Ibid, at 46.

62 Ibid, at 30 .

${ }^{63}$ Paul Hekkert and Helmut Leder "Product Aesthetics" in Hendrik Schifferstein and Paul Hekker (eds) Product Experience (Elsevier Ltd, Amsterdam, 2008) 259 at 259.

${ }^{64}$ See, for example, Karl Grammer and Randy Thornhill "Human (Homo sapiens) facial attractiveness and sexual selection: The role of symmetry and averageness" (1994) 108 J Comp Psychol 233; T Jacobson and L Höfel "Descriptive and evaluative judgement process: Behavioral and electrophysiological indices of processing symmetry and aesthetics" (2003) 3 CABN 289; and R Reber, N Schwarz and P Winkielman "Processing fluency and aesthetic pleasure: Is beauty in the perceiver's processing experience?" (2004) 8 PSPR 364.

${ }^{65}$ Grammer and Thornhill, above n 64, at 234.

${ }^{66}$ Ibid.
} 
for symmetry transfers to objects on a subconscious level. Contrast is another example, with studies showing that a balance between simplicity and complexity generates appeal. ${ }^{67}$ People tend to have a preference for recognisable patterns and order. ${ }^{68}$ Paul Locher, Kees Overbeeke and Pieter Stappers demonstrated this in their study, where they tracked the eye movements of people observing paintings. ${ }^{69}$ The study showed that slightly altering paintings that were known to the observer resulted in increased eye movement and less fixation, indicating the observer's search for recognisable patterns. ${ }^{70}$ Highly complex patterns tend to be less appealing, as people will often struggle to make sense of them. People tend to prefer patterns that they are able to comprehend. Patterns that are too simple, however, tend to lead to boredom and disinterest. Thus, complex patterns, in which order can be discerned after increased exposure, tend to generate greater satisfaction once comprehension is achieved..$^{71}$

The other seemingly paradoxical element of the contrast principle is the tendency to prefer what we know to be appropriate, while at the same time preferring novelty. ${ }^{72}$ The tendency to prefer that which we know can be observed in general everyday life. We tend to like the people we know, the comfort of our own homes, etc. ${ }^{73}$ This tendency is also arguably biological. As there is potential danger in things and places that are strange to us, it has instinctively always been a matter of survival to be cautious and apprehensive of strangeness. ${ }^{74}$

\footnotetext{
${ }^{67}$ See F Boselie "The golden section has no special aesthetic attractivity" (1992) 10 ART 1; Paul Locher, Kees Overbeeke and Pieter Stappers "Spatial balance of color triads in the abstract art of Piet Mondrian" (2005) 34 Perception 169; and Shahabeddin Khalighy and others "Quantifying the qualities of aesthetics in product design using eye-tracking technology” (2015) 49 Int J Ind Ergon 31.

${ }^{68}$ Hekkert and Leder, above n 63, at 262.

${ }^{69}$ Paul Locher, Kees Overbeeke and Pieter Stappers "Spatial balance of color triads in the abstract art of Piet Mondrian" (2005) 34 Perception 169 at173.

${ }^{70}$ Ibid, at 187.

${ }^{71}$ Hekkert and Leder, above n 63, at 265.

${ }^{72}$ Ibid.

${ }^{73}$ Ibid, at 267.

${ }^{74}$ Ibid, at 272.
} 
We also have a tendency, however, to dislike too much of the same thing. As with patterns that are too simplistic, interest is lost in things that become too familiar. ${ }^{75}$ More interest tends to be generated when elements of novelty are incorporated into what we already know, in a manner that is surprising, but not too strange. ${ }^{76}$ The surprise must thus still be perceived as sensible. For an example of this in the context of industrial design, consider a sports car. Customers are likely to consider low height and a body-kit as appropriate design features. Thus, appeal is likely to be dependent on the inclusion of other sensible features that have not previously been experienced by customers. ${ }^{77}$ The design should effectively enable consumers to experience the product in a new and enjoyable way.

It must be noted however, that merely observing these universal principles when developing a design does not guarantee success. After all, what individuals consider simple or complex, appropriate or novel, varies considerably. Then there are other discrepancies in taste and preference, which are products of communal factors such as religion and culture. ${ }^{78}$

This does not, however, negate the existence of universal principles, for there are even commonalities among cultures and religions, not only across the globe, but even across time. For example, there are certain principles that can be observed in different religions, including those of the ancient world. ${ }^{79}$

\footnotetext{
${ }^{75}$ Ibid, at 268 .

${ }^{76}$ Ibid, at 270.

${ }^{77}$ Khalighy and others, above n 67, at 33.

${ }^{78}$ Hekkert and Leder, above n 63, at 277.

${ }^{79}$ Claudia Bickmann "The Idea of a Highest Divine Principle - Founding Reason and Spirituality" (2012) 3 Religions 1025 at 1027.
} 
To understand why there are such large discrepancies in spite of commonalities, it is perhaps best to think of each universal principle as a spectrum. Although we are all subject to these principles, the degree of our subjugation varies. ${ }^{80}$

Industrial designers who understand the scale nature of the universal principles closely study and assimilate their target market to discern patterns in taste and preference. By so doing, they significantly increase their chances of developing a product appearance that will successfully appeal to the majority of customers. The appearance or eye appeal, however, is only a part of aesthetics, albeit a large part under traditional Western aesthetic theory.

\subsubsection{Western aesthetic theory}

Under traditional Western aesthetic theory, which in some respects can be traced back to the writing of Plato and Aristotle, ${ }^{81}$ the senses are perceived hierarchically. ${ }^{82}$ Sight and hearing are high senses while the other senses, namely touch, taste and smell, are low senses. ${ }^{83}$ The latter are low senses because they are seen as incapable of perception independent of the needs and desires of the body. ${ }^{84}$ In other words, these senses are subjugated to the body, whereas the higher senses are capable of perception that transcends the body. Thus, all creative expression is, according to traditional Western aesthetic theory, perceived by these senses. ${ }^{85}$

\footnotetext{
${ }^{80}$ Hekkert and Leder, above n 63, at 277.

${ }^{81}$ Buccafusco, above n 23, at 506.

${ }^{82} \mathrm{Ibid}$, at 507.

${ }^{83}$ Ibid.

84 Ibid.

${ }^{85}$ Ibid.
} 
Contemporary aesthetic theory, however, seems to be moving away from the hierarchical understanding of the senses, while the view that all senses are capable of perceiving creative expression is becoming increasingly accepted. ${ }^{86}$

Indeed, the notion that touch is an inferior sense seems implausible when one considers the fact that it is the core sense for perceiving the physical world. ${ }^{87}$ Marieke Sonneveld and Hendrik Schifferstein use the example of interacting with a frog to illustrate this point. They explain that we can see the size, colour and shape of the frog. We can also hear the sounds it makes and even smell it, but it is only through touch that we can actually feel the physical characteristics of the frog, such as its weight, temperature, sliminess, elasticity, etc. ${ }^{88}$ Moreover, it is through such tactile interaction that we perceive the border between ourselves as individual beings and the rest of material existence. ${ }^{89}$ For this reason, it is our most intimate sense. ${ }^{90}$ Smell too is a highly intimate sense. In fact, in a study carried out by Rachel Herz and Jonathan Schooler, smell was identified as the sense that most frequently triggers emotionally meaningful memories. ${ }^{91}$

A meaningful experience can likewise be perceived through the gustatory sense. Although eating is necessary for the body's survival, just because we need to eat does not mean we need to taste. ${ }^{92}$ Carolyn Korsmeyer explains how the gustatory sense can be the receptor for creative expression. People tend to associate certain tastes with certain times of year and celebrations, ${ }^{93}$

\footnotetext{
${ }^{86} \mathrm{Ibid}$, at 508 .

${ }^{87}$ Marieke Sonneveld and Hendrik Schifferstein "The Tactual Experience of Objects" in Hendrik Schifferstein and Paul Hekker (eds) Product Experience (Elsevier Ltd, Amsterdam, 2008) 41 at 43.

${ }^{88} \mathrm{Ibid}$, at 44.

${ }^{89} \mathrm{Ibid}$, at 43.

90 Ibid, at 44.

${ }^{91}$ Rachel Herz and Jonathan Schooler "A naturalistic study of autobiographical memories evoked by olfactory and visual cues: testing the Proustian hypothesis" (2002) 115 Am J Psychol 21 at 22.

92 Buccafusco, above n 23, at 539.

${ }^{93}$ Carolyn Korsmeyer Making Sense of Taste: Food and Philosophy (Cornell University Press, New York, 1999) at 137 .
} 
such as, for example, Christmas or Easter. In the preparation of a particular dish, a chef will sometimes manipulate such associations to conjure up related feelings and emotions in order to create a particular kind of dining experience. ${ }^{94}$

Even though creative expression has been traditionally communicated via the auditory and visual senses, it was not always exclusively communicated as such. A good novel, for example, is still able to communicate to our gustatory, tactile and scent senses by description, which then enables us to experience the relevant sensations by drawing on our own analogous experiences.

Moreover, just as we are able to draw on our own experiences to perceive described gustatory, tactile and scent sensations, we are also subjugated to these so called low senses when we see a delicious hamburger on television, for example. This appears to debunk the notion that the visual and auditory senses allow us to perceive independently of the body's needs and desires. Thus, it seems more accurate to say that all of our senses are subjugated to the needs and desires of the body. Understanding senses in a hierarchical manner seems to imply that they are somehow separate entities, or that they are at least subject to separate entities, namely the mind and the body, with the higher senses being subject to the mind, and the lower senses to the body. ${ }^{95}$

In reality, however, the senses are not separate entities, but, rather, different receptors of the same single core. Depending on your individual perspective, this single core may be simply called the mind, consciousness, or, as Alfred Whitehead explained, "the Platonic and Christian

\footnotetext{
${ }^{94} \mathrm{Ibid}$

${ }^{95}$ Buccafusco, above n 23, at 529 .
} 
doctrines of the Soul, the Epicurean doctrine of a Concilium of subtle atoms or the Cartesian doctrine of Thinking Substance." 96

\subsubsection{Traditional Chinese perception of aesthetics}

According to the traditional Chinese perspective, aesthetics is in the relationship between the article and the individual. ${ }^{97}$ Similarly to pragmatist philosophy, according to the traditional Chinese view, beauty is subject to the experience of the one perceiving it. ${ }^{98}$ Without a conscious witness, a landscape sits in oblivion. The landscape only becomes a subject of perception in the presence of a conscious witness. ${ }^{99}$

Moreover, as beauty was considered to be a subjective concept, Chinese people did not appear to regard certain senses as being capable of perception independently of the body. There is also evidence to suggest Chinese people have traditionally appreciated the significance of more than just the auditory and visual senses. Evidence of early appreciation for the tactile sensation are the traditional Chinese pocket objects, which were carved specifically for the purpose of being handled while one's hand was in the pocket. ${ }^{100}$ In fact, a study by Robert Nisbett showed that Asian cultures generally tend to be much more holistically perceptive than their Western counterparts. ${ }^{101}$

\footnotetext{
${ }^{96}$ Alfred Whitehead The Interpretation of Science (Bobbs-Merrill, Indiana, 1961) at 234.

${ }^{97} \mathrm{Wu}$ Yao and Jae-Hwan Lee "Aesthetics Research of Chinese Traditional Lamps and Lanterns Using Product Semantics" (2011) 24 KSDS 437 at 448.

${ }^{98}$ Lang Ye "Several Inspirations from Traditional Chinese Aesthetics" (2010) 2 Procedia Soc Behav Sci 7556 at 7556.

${ }^{99}$ Ibid, at 7557.

${ }^{100}$ Buccafusco, above n 23, at 539.

${ }^{101}$ Robert Nisbett The geography of thought: How Asians and Westerners think differently... and why (The Free Press, New York, 2003) at 89.
} 
Contemporary aesthetic theory is, however, an indication that the Western world is also becoming increasingly holistic in aesthetic perception. For this reason, industrial designs are often not just about eye appeal. Moreover, industrial designs are not even just about aesthetics. Industrial designers will often have other objectives in conjunction with aesthetics, such as functional and ergonomic objectives. This broader design perspective is becoming increasingly prevalent among design-oriented companies. Consider, for example, the following philosophy of company ' $\mathrm{B}$ ':

We have this basic idea ... we call it - I look, I get, I feel. That is what we try to put into design. If I buy a mini cooper, I want to - look good in it, get lots out of it, and feel great.

\subsubsection{Function}

"The function drives the product. That is really, really important. It is not just about what it looks like. It is about how it delivers on the idea', explained company ' $\mathrm{B}$ '.

Indeed, most industrial products are more than just decorative and will have some utilitarian purpose. Thus, in addition to providing for several other considerations, the design of a product must also be appropriate for its utilitarian purpose. Non-utilitarian design aspects may support, accentuate or show off the utilitarian aspects, but they must never impede on the product's functionality.

\subsubsection{Ergonomics}

"Strictly speaking, ergonomics means the study of work and man", explained company 'B'. 
Essentially, ergonomics is the element of design that addresses the interaction of the user with the product. Academic 'C' described it as:

The way the body fits with the product. It is the thing that design often hangs its hat on.

It is how it quantifies itself and justifies its position in the world. Otherwise people go

“Oh it's just styling”.

Design is of course not just styling. The ergonomic aspect of design reflects considerations for the user's interaction with a product by designing for the enhancement of the user's experience, in regard to his or her comfort, pleasure, safety, health maximisation and so on. ${ }^{102}$

Several of the companies interviewed noted the importance of developing ergonomically sound designs. "You would not design a chair that looks beautiful, but is not comfortable. All of our pieces are fit for purpose as well as ergonomic", explained a furniture design company (company ' $\mathrm{H}$ '). "Whether it be the motion of a door, or the feel of a handle, we try to make sure that ergonomically our products work very well”, stated company 'E'.

A legal practitioner specialising in intellectual property (legal practitioner 'I') suggested the design of an Xbox controller is one obvious example of an ergonomic design. "Humans obviously have two hands, so there is no use making an Xbox controller that needs four hands to operate."

The swivel handle on a vacuum cleaner is another example. This ergonomic design was created after a study showed that users suffered from stiff and sore wrists after long duration

\footnotetext{
102 Jonathan Cagan and Craig Vogel "Understanding and Protecting Value in New Product Development" (paper presented to the International Conference on Engineering Design, Stockholm, August 2003) at 3.
} 
vacuuming. ${ }^{103}$ The swivel design was thus created to serve the function of alleviating the tension off the user's wrist. ${ }^{104}$

Another good example of ergonomic design was provided by company ' $\mathrm{F}$ '. Referring to the design of levers and buttons on their products, they mentioned:

Gripping points ... as well as ... the pressure required to activate them ... the angle they may be viewed ... or accessed from. All of those things are considered. All those human factors are taken into account.

It is noteworthy, as legal practitioner 'I' pointed out, that ergonomic design is not necessarily limited to human user considerations. "There are ... products that are designed for specific use, albeit not for humans ... an example would be the dog collar."

\subsubsection{Other aspects of industrial designs}

Beyond ergonomics, there are often further considerations involved in the development of industrial designs, such as time and budget constraints, environmental concerns, as well as the demands of handling, transportation and storage. ${ }^{105}$ Moreover, certain industrial designs may be subject to legal regulations. ${ }^{106}$ For example, in New Zealand an industrial designer designing a toy for children under 36 months of age will need to comply with Product Safety Standards (Toys) Regulations 2005. ${ }^{107}$ "It is vital that all core products ... are designed to ensure safety of infants, toddlers and pre-schoolers. Hence, a major focus ... is to examine product designs

\footnotetext{
${ }^{103}$ Sungho Kim and others "Learning from Successes and Failures of Registration of Patent Applications Based on Physical Ergonomics Research" (2015) 34(5) J Ergon Soc Korea 455 at 458.

${ }^{104}$ Ibid, at 457.

${ }^{105}$ Peter Bloch "Seeking the Ideal Form: Product Design and Consumer Response" (1995) 59(3) J Mark 16 at 19.

${ }^{106} \mathrm{Ibid}$, at 18 .

${ }^{107}$ Commerce Commission New Zealand "Children's Toys: A Guide to Complying with the Product Safety Standard" (2009)<www.comcom.govt.nz> at 1.
} 
from a safety perspective", explained a company that designs children's products (company 'J').

Children's products are not the only designs subject to product safety standards. Company ' $G$ ' noted that their designs are also subject to several safety standards: "There are massive restrictions over certification. You cannot sell an electrical product in any form without having it certified."

Moreover, once the designs are marketed on an international scale, there are even more standards that need to be complied with. "In Europe it is a slightly different standard. Ours is theirs plus a little bit. In America it is a completely different standard”, company 'G' explained.

Company 'B' also considered this to be a substantial obstacle for their design:

We have to do four or five standards. So we have United States standards, we have Australian and New Zealand standards, we have European standards, we have British standards, and we have one product.

All of these legal regulations on top of the monumental challenge of actually developing a design that successfully appeals to consumers should, at least in theory, be a major disincentive, yet there is no shortage in industrial design variety. The reason for this is that industrial designs are very valuable. The following section thus discusses the economic value of industrial designs for businesses. 


\subsection{Industrial Design Value}

"Good design is really a significant enabler for success. We care about our design, owning it and building it ourselves. Rather than just trading ... we want to be accountable for what we think and what we build", stated company 'B'.

Indeed, industrial designs can add substantial value to businesses. However, it is notoriously difficult to determine their precise economic value. It was illustrated in the discussion above that industrial designs are more than just the appearance of products. It is thus inaccurate to perceive industrial designs as such. Determining the precise value of industrial design is very difficult due to it comprising so many interrelated and intertwining elements. ${ }^{108}$ Indeed, the more superficial view simplifies the process of quantification. However, such simplified numbers are not helpful in understanding the true value of industrial designs.

Drew Voth and his co-authors identify several relatively simple methods for quantifying the value of intellectual property, which can include industrial designs. One such method is the excess profit method, which measures the value of intellectual property by calculating the difference between products that contain intellectual property with similar kinds of products that do not contain intellectual property. ${ }^{109}$ However, this method does not separate intellectual property from other potential factors that affect profits. ${ }^{110}$

\footnotetext{
108 World Intellectual Property Indicators (prepared by World Intellectual Property Organization, 2012) at 22. ${ }^{109}$ Drew Voth, Brian Park and Nathan Brunette "Apportionment of Intellectual Property Value: Where Economic Theory Meets Legal Practice (2013) 71 Fed Law 73 at 74.

${ }^{110}$ Ibid, at 76 .
} 
The profit split method, however, aims to do precisely that, by splitting the profits between all the different assets that a company has, including intellectual property. ${ }^{111}$ Voth et al question the accuracy of this method due to the intertwined relationship between intellectual property and other assets. They point out that, in order to precisely split the profits, one must be able to answer some very difficult questions, such as what is the right split and how can it be supported $?^{112}$

The cost approach method attempts to quantify the value of intellectual property by looking at the problem from a different angle. This approach calculates the value by simply adding up all the costs associated with intellectual property. ${ }^{113}$ The relevant costs can include legal costs such as various intellectual property application, registration or licensing costs. ${ }^{114}$ It will also usually include research and development costs, as well as other potential labour and capital costs, and perhaps even opportunity costs. However, most valuation professionals agree that cost is not the best indication of the value of income-generating assets, because the approach does not take account of the expected returns on investment. ${ }^{115}$

Voth et al examine several methods for calculating the value of intellectual property, including those discussed above. However, they identify substantial limitations in each, demonstrating the difficulty of accurately quantifying the value of any type of intellectual property, including industrial designs. That does not mean that the value of intellectual property is not recognisable. The value can be illustrated by other means, by, for example, illustrating a positive relationship between expenditure on industrial designs and a firm's financial performance.

\footnotetext{
${ }^{111}$ Ibid, at 74 .

112 Ibid, at 77.

113 Ibid, at 75 .

${ }^{114}$ Lloyd Austin "Accounting for intangible assets" (2007) 9 University of Auckland Business Review 63 at 63.

${ }^{115}$ Voth, Park and Brunette, above n 109, at 75.
} 
A comprehensive study carried out by Liang Guo showed the existence of such a relationship. The study collected data from a total of 1081 firms from 34 countries and across 46 different industries over an eight-year period (1998-2005). ${ }^{116}$ Guo measured the value of industrial designs by comparing the financial performance of firms that had won awards for their product designs with firms that did not win awards. The awards that were considered relevant for the study were the internationally recognised Chicago Athena Good Design Award and the German Red Dot Award. ${ }^{117}$ Design awards served as evidence of well-spent design expenditure, as winning designs had to stand up against the capricious critique of design experts. ${ }^{118}$ The ratio of award-winning firms versus non-winning firms in the study was roughly even. In total, there were 577 firms that won awards and 524 that did not. ${ }^{119}$

The study showed that design effectiveness (measured by the attainment of design awards) generally had a positive effect on financial performance in almost all industries. There was generally a very strong positive effect in industries that traditionally have little design focus, such as the metal-mining and machinery industries. Effective design also generally had a positive effect on financial performance in industries that traditionally have moderate design focus, such as the paper and plastic industries. ${ }^{120}$ However, in industries where design has traditionally been a major focus, such as the electronics and textiles industries, effective design rarely amounts to a competitive advantage any more. Rather it is a necessity without which firms are simply unable to compete. ${ }^{121}$ Effective design had a negative relationship with

\footnotetext{
${ }^{116}$ Liang Guo "Product Design and Financial Performance" (2010) Design Management Journal 5 at 9.

${ }^{117}$ Ibid, at 8.

${ }^{118}$ Ibid, at 10 .

${ }^{119}$ Ibid, at 9.

${ }^{120} \mathrm{Ibid}$, at 11

${ }^{121}$ Ibid, at 15.
} 
financial performance in many firms from emerging countries, and for some from the AsiaPacific region. For these firms, the costs of design were simply too high. ${ }^{122}$

There have been several other studies over the years that have also shown that effective design generally has a positive effect on a firm's performance. ${ }^{123}$

Beginning with a historic overview, and moving on to a thorough discussion of its constituent elements both in theory and in practice, the purpose of this chapter was to provide a thorough explanation of what an industrial design is. A good understanding of the concept and its value was necessary to proceed to the evaluative component of this study.

${ }^{122} \mathrm{Ibid}$, at 13 .

${ }^{123}$ For some examples, see C D Black and M J Baker "Success through Design" (1987) 8(4) Design Studies 207; G Gemser and M A Leenders "How Integrating Industrial Designs in the Product Development Process Impacts Company Performance" (2001) 18 J Prod Innov Manag 28; and J H Hertenstein, M B Platt and D R Brown "Valuing Design: Enhancing Corporate Performance through Design Effectiveness" (2001) 12(3) Design Management Journal 10. 


\section{Legal Protection for Industrial Designs in New Zealand}

Having outlined what industrial design is in the tangible sense and as a practice in Chapter 2, this chapter discusses the protection of industrial designs as intellectual property. The discussion therefore begins with a general overview of rationales for why intellectual property is legally protected. This is followed by an outline of minimum standards that have been set by international intellectual property treaties with respect to industrial design protection. References to China are also made in this part of the chapter to note the extent of its adherence to the international standards (China's domestic law is discussed in Chapter 4). The remainder of this chapter focuses on New Zealand intellectual property law as it relates to industrial designs. The discussion of the different protection mechanisms is limited to a general overview in this Chapter. In particular, the discussion of patents, trade marks, passing off and the Fair Trading Act 1986, is very brief as these mechanisms are rarely used for protecting industrial designs. The majority of the discussion is on the protection mechanism that are most commonly used in New Zealand to protect industrial designs, namely copyright and registered designs. In addition to the general overview, this chapter provides the contextual basis for the substantive arguments and analyses in Chapter 6, which informs the suggestions and recommendations, for New Zealand policy and its law makers, as to how to appropriately protect industrial designs.

\subsection{Rationale for Protecting Intellectual Property}

Although, there are several different rationales for why intellectual property should generally be protected, including the obvious utilitarian rational, it is arguable that New Zealand 
intellectual property law is underpinned significantly by instrumentalist rationale. ${ }^{1}$ According to this rationale, intellectual protection is a means for achieving social and economic aims. ${ }^{2}$ Such protection achieves its social objective by controlling the dissemination of knowledge and culture. ${ }^{3}$ Accordingly, exclusive rights are granted to individual creators for a period of time,${ }^{4}$ to incentivise ingenuity and creativity, ${ }^{5}$ and to allow the creator an opportunity to recoup on the resources they invested. ${ }^{6}$ The investment is of course usually more than simply monetary and will often include significant time, labour and creative effort. ${ }^{7}$ In economic terms, the provision of a period of exclusive right to the creator, serves the public interest because it provides recourse against those who freeride on another's investment ${ }^{8}$

Another rationale for intellectual property protection which underpins at least some intellectual property law in New Zealand, is the naturalist rationale. This rationale is grounded in theories such as Hegel's personality theory, and Locke's labour theory. ${ }^{9}$ Hegel's personality theory is a rights based theory that justifies intellectual property on the basis that it is an expression of one's will and thereby an extension of their personality. ${ }^{10}$ Industrial designs, can be viewed as expression of the designer's personality. A design may be reflective of a designer's personal views, beliefs or emotions. According to Locke, property arises from individuals applying

\footnotetext{
${ }^{1}$ I.e. economic incentive is necessary to promote creativity and innovation in society - see Adam Moore "Intellectual Property: Theory, Privilege, and Pragmatism" (2003) 16 Can JL \& Juris 191 at 196.

${ }^{2}$ Rebecca Giblin and Kimberlee Weatherall "If we redesigned copyright from scratch, what might it look like?" in Rebecca Giblin and Kimberlee Weatherall (eds) What if we could reimagine copyright? (ANU Press, Australia, 2017) 1 at 16.

${ }^{3}$ Ibid.

${ }^{4}$ For the copyright terms - see Section 3.3.3.2: Applicable categories; for the registered design term - see Section 3.3.4.5: Term of protection.

${ }^{5}$ Hugh Laddie and others The Modern Law of Copyright and Designs (3rd ed, Butterworths, London, 2000) vol 1 at 445 .

${ }^{6}$ Christopher Buccafusco, Mark Lemley and Jonathan Masur "Intelligent Design (2018) 68 Duke LJ 75 at 82.

${ }^{7}$ See Section 2.2: The role of the Industrial designer for discussion re the extent of creative investment in industrial design.

${ }^{8}$ Rebecca Giblin "Reimagining copyright's duration" in Rebecca Giblin and Kimberlee Weatherall (eds) What if we could reimagine copyright? (ANU Press, Australia, 2017) 177 at 181.

${ }^{9}$ Giblin and Weatherall, above n 2, at 17.

${ }^{10}$ Georg Hegel Grundlinien der Philosophie des Rechts (Ullstein, Frankfurt am Main, 1972) (translated ed: T M Knox (Translator) Georg Hegel Philosophy of Right (Oxford University Press, Oxford, 2008)) at 67.
} 
their labour to things. ${ }^{11}$ The proviso of Lockean theory is that an individual must leave the common property from which they took a piece, in as good a state for others as when they came upon it. ${ }^{12}$ Applying this rationale to intellectual property, exclusive rights are only justified in the value produced, but do not extend to the source or raw resources from which the intellectual property is generated. ${ }^{13}$

According to the naturalist rationale, creators should be rewarded with exclusive rights as of right. ${ }^{14}$ Creations are a product of labour and the personality of their creators, ${ }^{15}$ and as such deserve protection. ${ }^{16}$

Another perspective, although not a traditional rationale, but one that certainly draws on naturalist notions, is that of fairness and equal treatment. All creations that reach an objective standard of being deserving, should equally be entitled to protection, so long as they do not unduly restrict further creativity. ${ }^{17}$ Provided this proviso is satisfied, Martin Senftleben argues that it should not matter, in an ideal world, what the creator's incentives are. ${ }^{18}$ Creators are not necessarily always driven by money. ${ }^{19}$ Rather, they may be incentivised by the attainment of recognition in their field, ${ }^{20}$ be seeking to solve some kind of problem, or even be merely creating out of a compulsion to create. ${ }^{21}$ However, the mere fact that a creator may not be

\footnotetext{
${ }^{11}$ John Locke Two Treatises of Government (University of Chicago Press, Chicago, 1990) at 130.

${ }^{12}$ Ibid, at 130.

${ }^{13}$ Kenneth Himma "The Justification of Intellectual Property: Contemporary Philosophical Disputes" (2008) 59 JASIST 1143 at 1155.

${ }^{14}$ Martin Senftleben "Copyright, creators and society's need for autonomous art - the blessing and curse of monetary incentives" in Rebecca Giblin and Kimberlee Weatherall (eds) What if we could reimagine copyright? (ANU Press, Australia, 2017) 25 at 29.

${ }^{15}$ Giblin, above $\mathrm{n} 8$, at 192.

${ }^{16}$ Anthony Reese "What should copyright protect?" in Rebecca Giblin and Kimberlee Weatherall (eds) What if we could reimagine copyright? (ANU Press, Australia, 2017) 111 at 115.

${ }^{17}$ Wendy Gordon "A Property Right in Self-Expression: Equality and Individualism in the Natural Law of Intellectual Property (1993) 102 Yale LJ 1533 at 1565.

${ }^{18}$ Senftleben, above $\mathrm{n} 14$, at 26.

${ }^{19}$ Ibid, at 26.

${ }^{20}$ Ibid.

${ }^{21}$ Giblin, above n 8, at 193.
} 
incentivised by money, does not mean they should not be granted exclusory rights for a period of time, during which they could seek to exploit their creation for monetary gain, if they so choose. ${ }^{22}$ The option to exercise exclusive rights is provided, irrespective of the creator's expectations or motivations. From an equal treatment perspective, not doing so, would discredit the protection system. ${ }^{23}$

The rationales for copyright and registered designs are discussed below as these are the main mechanisms used for protecting industrial designs in New Zealand.

\subsubsection{Rationale underlying copyright protection}

Jeremy de Beer explains that as an economically grounded rationale, instrumentalism, accepts market processes and market-driven outcomes as being in the public interest. ${ }^{24} \mathrm{~A}$ copyright system that keeps prices as low as possible for the consumer however, is not the only relevant market consideration. ${ }^{25}$ Growth of creative industries is another important market-driven outcome. ${ }^{26}$ Therefore, providing for the creative interests of creators, is also in the public interest. $^{27}$

\subsubsection{Rationale underlying existing protection via the registered design system}

\footnotetext{
${ }^{22}$ Senftleben, above n 14, at 51.

${ }^{23}$ Ibid.

${ }^{24}$ Jeremy de Beer "Making copyright markets work for creators, consumers and the public interest" in Rebecca Giblin and Kimberlee Weatherall (eds) What if we could reimagine copyright? (ANU Press, Australia, 2017) 147 at 150 .

${ }^{25}$ Graeme Austin "Property on the Line: Life on the Frontier between Copyright and the Public Domain (2013) 44 VUWLR 1 at 14.

${ }^{26}$ Jeremy de Beer, above n 24, at 150 .

${ }^{27} \mathrm{Ibid}$, at 165 .
} 
Instrumentalism also underpins registered design protection in New Zealand. The registered design regime provides designers who create new or original designs with exclusive rights for a limited time. ${ }^{28}$ The limited time reflects the balance between the design owners' right to recoup on their investment and the public interest to fair competition. ${ }^{29}$

\subsubsection{Expanding the scope of protection for industrial designs}

As illustrated in Chapter 2, industrial design is an evolving practice and concept. Technology is continually expanding the boundaries of what is possible. Thus the creative capacity of designers is continually growing. As creative capacity grows, works are created which may not squarely fit the within the borders of the law. ${ }^{30}$ Should the scope of the law expand to accommodate such works? In addressing this question, arguments for and against expansion of copyright law and registered design law are considered, separately, below.

\subsubsection{Arguments against expanding the scope of copyright}

Anthony Reese argues that copyright scope should not be extended to protect every new type of creative work. ${ }^{31}$ As modern technology is developing very rapidly, such an approach is likely to lead to a flood of litigation. ${ }^{32}$ Some new works may not, from an instrumentalist perspective, require incentives for their creation, ${ }^{33}$ or the work may be so basic that there is no real

\footnotetext{
${ }^{28}$ For specifics of registered design protection - see Section 3.3.4: Registered designs.

${ }^{29}$ World Intellectual Property Organization What is Intellectual Property? (2016) at 13.

${ }^{30}$ The impact of advancing technology on industrial design is discussed in Chapter 5.

${ }^{31}$ Reese, above n 16, at 125.

${ }^{32}$ Ibid, at 114.

${ }^{33}$ This is of course also true for some works which are already protected under copyright.
} 
investment to recoup. ${ }^{34}$ In some instances, the work, from a naturalist perspective, may simply not be worthy of reward. ${ }^{35}$

Works created in still developing fields may be less likely to be worthy of legal protection, and their creators are less likely to seek protection. Such works are often, at least during the early stages, experimental prototypes of little commercial value. For example, in the video gaming industry in the 1970s, video game developers generally invested in innovating rather than litigating. ${ }^{36}$ Moreover, the simplicity and lack of creativity of early visual representations in games such as Pong, made them unlikely candidates for copyright protection. ${ }^{37}$ Over time however, as games became more and more intricate, copyright infringement claims increased. ${ }^{38}$ The extension of copyright protection to works created in the early stages in developing fields, may stifle creativity and progress in those fields. ${ }^{39}$ During the early stages, it may be difficult to clearly discern original creative expression. Expressions developed during this time are likely to be more synonymous with general ideas and thus should not be protected. ${ }^{40}$ Granting exclusive rights to creators during the early stages, forces competitors to tread more carefully in the creation of their own works so as not to risk infringing the copyright. ${ }^{41}$ This is not in the

\footnotetext{
${ }^{34}$ Reese, above n 16, at 138.

${ }^{35} \mathrm{Ibid}$, at 139.

${ }^{36}$ Greg Lastowka "Copyright Law and Video Games: A Brief History of an Interactive Medium" in Matthew David and Debora Halbert (eds) The SAGE Handbook of Intellectual Property (SAGE Publications, London, 2014) 495 at 500.

${ }^{37}$ Ibid.

${ }^{38}$ Ibid. Today copyright with respect to video games is recognised and treated as a complex and major issue right from the outset of game development - see Ministry of Business, Innovation \& Employment Copyright and the Creative Sector (2016) at 29. To date, games are not protected, as such, under a single copyright category. Rather, various aspects of games (e.g. music, software code, visual representations) are protected under different copyright categories.

${ }^{39}$ Buccafusco, Lemley and Masur, above n 6, at 83.

${ }^{40}$ Enrico Bonadio and Nicola Lucchi "Introduction: setting the scene for non-conventional copyright" in Enrico Bonadio and Nicola Lucchi (eds) Non-Conventional Copyright (Edward Elgar Publishing, Cheltenham, 2018) 1 at 14.

${ }^{41}$ Buccafusco, Lemley and Masur, above n 6, at 83.
} 
public interest, as it slows development in the field, ${ }^{42}$ sometimes dissuading individuals, who may be more creative, from contributing. ${ }^{43}$

The technology utilised in the development of the prototype expressions may be sufficiently innovative to be worthy of patent protection, ${ }^{44}$ but it is best not to extend copyright to the creative works themselves until original expression is clearly discernible. ${ }^{45}$

In some fields however, creative works should arguably never be protected. It may be unwise to introduce copyright protection to fields where there is no lack of creativity. Copyright in such fields may disturb the equilibrium of creativity established by the market. ${ }^{46}$

For example, one argument is that the fashion industry in the United States is prosperous because it is not subject to copyright. ${ }^{47}$ If designers had enforceable rights against those that copy their designs, copying would logically diminish, allowing original designers to profit from their designs for longer periods of time, thus reducing their incentive to innovate so rapidly. ${ }^{48}$ It is thus arguable that the exclusion of copyright is beneficial for the greater society. First, the status quo provides poorer consumers (because of the availability of cheap alternative copies) with fashionable designs at affordable prices. ${ }^{49}$ Secondly, the status quo appears to encourage rapid creativity and innovation in the industry. ${ }^{50}$

\footnotetext{
${ }^{42}$ Reese, above n 16, at 137.

${ }^{43} \mathrm{Ibid}$, at 139.

${ }^{44}$ Lastowka, above n 36, at 500.

45 Bonadio and Lucchi above n 40, at 14.

46 Tim Dornis "Non-conventional copyright: an economic perspective" in Enrico Bonadio and Nicola Lucchi (eds) Non-Conventional Copyright (Edward Elgar Publishing, Cheltenham, 2018) 455 at 458.

${ }^{47}$ Kal Raustiala and Christopher Sprigman "The Piracy and Paradox: Innovation and Intellectual Property in Fashion Design" (2006) 92 VA L Rev 1687 at 1689. Fashion designs are not protected under copyright in the United States because of the functional nature of clothes.

${ }^{48}$ Ibid, at 1722.

${ }^{49}$ Mary Miller "Copyrighting the Usful Art of Couture: Expanding Intellectual Property Protection for Fashion Designs (2014) 55 Wm \& Mary L Rev 1617 at 1641.

${ }^{50}$ Raustiala and Sprigman, above n 47, at 1689.
} 
Although they do not have recourse to copyright, fashion designers in the United States may be able to protect their businesses by way of trade mark protection, ${ }^{51}$ as well as trade dress and the tort of breach of confidence..$^{52}$

\subsubsection{Arguments for expanding the scope of copyright}

Copyright can be readily adapted to embrace technological development. ${ }^{53}$ Computer programs are an example of works for which the borders of copyright protection were extended. ${ }^{54}$ What makes the extension possible is the non-specificity of the protected categories of work. ${ }^{55}$ It the categories were too specific, this would not serve the public interest, as copyright protection would not be able to adapt in response to advances in technology. ${ }^{56}$

The fear that too much flexibility is likely to lead to a flood of litigation should be mitigated by an appreciation for copyright's intrinsic accommodation for the public interest. First, copyright only prohibits copying. ${ }^{57}$ If the same design is developed by two designers completely independently, neither one can succeed in a copyright infringement claim against the other. ${ }^{58}$ Moreover, even though in a case of alleged infringement, courts will infer copying (where there has been access and an allegedly infringing work is substantially similar to a copyright protected work), the inference is nevertheless subject to the idea/expression dichotomy. That is, copyright only protects the particular way in which ideas are expressed,

\footnotetext{
${ }^{51}$ Matteo Mancinella “Copyright Subject Matter and a Light for Designers' Rights” (2012) 29 Santa Clara Computer \& High Tech L J 523 at 550.

${ }^{52}$ Kim Williams, Jennifer Laing and Warwick (eds) Fashion, Design and Events (Routledge, Oxfordshire, 2014) at 105 .

${ }^{53}$ Reese, above n 16, at 124.

${ }^{54}$ Bonadio and Lucchi above n 40, at 2.

${ }^{55}$ Reese, above n 16, at 124.

${ }^{56}$ Ibid.

${ }^{57}$ Buccafusco, Lemley and Masur, above n 6, at 99.

58 Anna Kingsbury "International harmonisation of designs law: the case for diversity" (2010) 32 EIPR 382 at 383.
} 
rather than the underlying ideas themselves. ${ }^{59}$ Although, in some cases, the line between idea and expression is hard to draw, ${ }^{60}$ the downside of not drawing it, is clear. It is important that general ideas remain in the public domain, so as to allow others to utilise them in the development of their own creations. ${ }^{61}$ Thus, designers in developing fields are free to draw on, or build on, the underlying ideas expressed in copyright protected works. ${ }^{62}$ Ensuring that aspects of works, which are more synonymous with ideas, remain in the public domain, ${ }^{63}$ is a matter of public policy. ${ }^{64}$ Restricting others from utilising such aspects in the development of their own works would be detrimental to society because it would stifle creativity. Copyright doctrine recognises that all creative works draw to some extent on ideas expressed in works that went before them. ${ }^{65}$ The idea/expression dichotomy which underlies copyright should therefore ensure that the extension of copyright, to works which challenge the current boundaries of copyright, does not stifle creativity in developing fields. As Graeme Austin reminds us, copyright can develop and evolve, while nevertheless maintaining its traditional bounds. $^{66}$

With respect to the perception that the fashion industry in the United States is prosperous because its designs are not protected by copyright, the following factors need to be taken into account. First, fashion designs are not protected under copyright in the United States because they are useful articles (in the sense that they have an intrinsic utilitarian function). However,

\footnotetext{
59 Hugh Laddie, Peter Prescott and Mary Vitoria The Modern Law of Copyright and Designs (2nd ed, Butterworths, London, 1995) vol 1 at 100.

${ }^{60}$ Mancinella, above $\mathrm{n}$ 51, at 527.

${ }^{61}$ Buccafusco, Lemley and Masur, above n 6, at 93. Cf. the proviso of Lockean theory that an individual must leave the common property from which they took a piece, in as good a state for others, as when they came upon it (See John Locke Two Treatises of Government (University of Chicago Press, Chicago, 1990) at 130).

${ }^{62}$ Laddie and others, above $\mathrm{n} 5$ at 98.

${ }^{63}$ Note, especially novel industrial designs may be able to be to be protected via a patent - see Section 3.3.1: Trade marks and patents.

${ }^{64}$ Laddie and others, above $\mathrm{n} 5$ at 105.

${ }^{65}$ Ibid.

${ }^{66}$ Graeme Austin "Copyright's Modest Ontology - Theory and Pragmatism in Eldred v Ashcroft” (2003) 16 Can JL \& Jurisprudence 163 at 177.
} 
original patterns imprinted on fabric can still be protected by copyright. ${ }^{67}$ Secondly, the faddish nature of fashion designs, means they are typically seasonal anyway. ${ }^{68}$ The life-cycle of a popular fashion design is arguably much too short for the law to intervene. ${ }^{69}$ By the time a copyright infringement suit is filed, the fashion world is likely to have moved on.

Moreover, there are obvious detriments to at least some fashion designers. Lack of copyright protection allows major chains to simply copy the work of designers and thus effectively free ride on their creative labour. ${ }^{70}$ Popular designers can rely on their reputations and brands to distinguish themselves in the market. ${ }^{71}$ Moreover, their reputations enable them to have recourse to trade mark and trade dress protection against counterfeiters. ${ }^{72}$ Trade marks are of little use however, to new designers who do not yet have a reputable brand worth imitating. New designers are also highly unlikely to succeed in a trade dress action, ${ }^{73}$ because an investment of considerable time and money is required for one's designs to acquire a secondary meaning. ${ }^{74}$ This is because the primary significance of trade dress is an identity of source in the mind of the public. ${ }^{75}$ New designers do have the same recourse as popular designers to the tort action of breach of confidence. However, this tort is only useful during the development stage, prior to the design being publically displayed. ${ }^{76}$ Breach of confidence does not provide protection once the design is out in the market.

\footnotetext{
${ }^{67}$ See Star Athletica LLC v Varsity Brands Inc 137 (S Ct 2017) 1002.

${ }^{68}$ Veronique Pouillard "The Milton Case (1955 - 1962): Defending the Intellectual Property Rights of Haute Couture in the United States" (2017) 30 Journal of Design History 356 at 363.

${ }^{69}$ Ibid at 357.

${ }^{70}$ Mancinella, above $\mathrm{n} 51$, at 550.

${ }^{71}$ Ibid, at 555 .

${ }^{72}$ Nettie Mills "Intellectual Property for Fashion Design: An Overview of Existing Law and a Look Toward Proposed Legislative Changes" (2008) 5 Shidler J L Com \& Tech 1 at 3.

${ }^{73}$ Analogous to the tort action of passing off in New Zealand.

${ }^{74}$ Mancinella, above $\mathrm{n} 51$, at 553.

${ }^{75}$ See Qualitex Co v Jacobson Prods Co 515 US 159 (1995) at 163.

${ }^{76}$ Charles Cronin "Law and odor: elusive copyright and other IP protection for fragrances" in Enrico Bonadio and Nicola Lucchi (eds) Non-Conventional Copyright (Edward Elgar Publishing, Cheltenham, 2018) 340 at 352.
} 
Copyright would thus be especially useful for new fashion designers ${ }^{77}$ Furthermore, copyright protection, would not prevent affordable fashionable designs being available to poorer consumers. Although cheap counterfeits of the work of prestigious designers would of course be prohibited, copyright will not altogether eradicate the market for more affordable designs that draw inspiration from their work. This is because copyright's idea/expression dichotomy would allow designers in the United States to draw on the fashionable designs of others. ${ }^{78}$ They just will no longer be able to directly or indirectly copy a particular design expression or a substantial part of it.

In Europe (as in New Zealand), fashion design is protected by copyright. ${ }^{79}$ Nevertheless, copyright litigation concerning fashion design infringement in Europe is rare. ${ }^{80}$ This indicates that the existence or absence of copyright is not a significant variable in the industry. Rather, the driving force behind the rapid pace of innovation and creativity in the industry appears to be conspicuous consumption. ${ }^{81}$ That is, the tendency of human beings to enjoy showing off their new possessions to their peers. ${ }^{82}$ This human trait fuels a constant demand for the fashion industry to satisfy. ${ }^{83}$ The fashion industry in the United States is not therefore necessarily an example of an industry that is prosperous because its designs are outside the scope of copyright.

Although another possibility is to create sui generis systems to protect original creative works that do not fit the existing boundaries of copyright, Tim Dornis suggests it is usually better to

\footnotetext{
${ }^{77}$ Mancinella, above $\mathrm{n} 51$, at 544.

${ }^{78}$ Miller, above n 49, at 1641.

${ }^{79}$ Raustiala and Sprigman, above n 47, at 1735.

${ }^{80} \mathrm{Ibid}$, at 1737.

${ }^{81}$ Ibid at 1734.

${ }^{82}$ See Thorstein Veblen The Theory of the Leisure Class: An Economic Study of Institutions (Unwin, London, 1970).

${ }^{83}$ See Elizabeth Segran "Your H\&M Addiction is Wreaking Havoc on the Environment. Here's how to break it" Fast Company (2019) <www.fastcompany.com>.
} 
take incremental steps to expand the scope of copyright for such works, rather than trying to re-invent the wheel every time. ${ }^{84}$

3.1.3.3 Arguments against expanding the scope of registered design law

Similarly to other intellectual property protections, registered design protections often lead to products being more expensive for the consumer. ${ }^{85}$ Registered designs provide a monopoly right, which can restrict others working in that field. Designers who wish to incorporate substantial aspects of another designer's registered design into their own work need to seek a licence from the owner. The fees for such licences, being at the discretion of the design owner, may be excessive, while the only alternative is to engage in the risky business of trying to design around any protected aspects. ${ }^{86}$ Permitted exceptions in accommodation of the public interest are limited in comparison to the exceptions provided under copyright law. ${ }^{87}$ Noninfringing use of registered designs without the consent of the owner is limited to a compulsory licence, which may be granted if it is shown that the registered design is not actually being applied in New Zealand to the article in respect of which it is registered. ${ }^{88}$ The only other permitted exceptions are for certain types of Crown use. ${ }^{89}$

3.1.3.4 Arguments for expanding the scope of registered design law

\footnotetext{
${ }^{84}$ Dornis, above n 46, at 473.

${ }^{85}$ Christine Greenhalgh and Mark Rogers "The value of intellectual property rights to firms and society" (2007) 23 Oxf Rev Econ Policy 541 at 545.

${ }^{86}$ Buccafusco, Lemley and Masur, above n 6, at 83.

${ }^{87}$ See Part 3 of the Copyright Act 1994 (NZ).

${ }^{88}$ See Designs Act 1953 (NZ), s 14.

${ }^{89}$ See Designs Act 1953 (NZ), s 16.
} 
If the scope of registered design protection were to be expanded to designs being created in developing fields, this may not overly impede on the public interest. This is because the monopoly that the registered design system provides is not extensive. Only new or original designs are registrable. ${ }^{90}$ Registered designs protect a particular appearance applied to an article by an industrial process or means. ${ }^{91}$ Other designers will infringe the registered design if their designs are substantially similar to that appearance. ${ }^{92}$ Moreover, what is substantial is dependent on the prior art. If variations in the registered design are minor with respect to earlier designs, then further minor variations will likely avoid infringement of the registered design. ${ }^{93}$

This is not the only restriction on the monopoly in favour of the public interest. Solely functional features may not be registered, ${ }^{94}$ as these are features that should be freely accessible to all. Moreover, evidence illustrating that a particular function can be embodied in a different form, is not necessarily sufficient to dismiss a particular feature as being dictated solely by function. ${ }^{95}$

Another example of a restriction on the monopoly provided by a registered design is that design is protected only with respect to the article to which it is applied, and in respect of which it is registered. ${ }^{96}$ Thus others may incorporate the design into different articles.

\footnotetext{
90 See Designs Act 1953 (NZ), s 5.

${ }^{91}$ See Designs Act 1953 (NZ), s 2.

92 UPL Group Limited v Dux Engineers Limited [1989] 3 NZLR 135 (CA) at 139.

${ }^{93}$ Ibid.

${ }^{94}$ See Designs Act 1953 (NZ), s 2.

95 See discussion in Section 3.3.4.1.3: "Not features of shape or configuration which are dictated solely by function".

${ }^{96}$ Designs Act 1953 (NZ), s 11.
} 
With the above restrictions in place, there appears to be minimal risk that the monopoly provided by the registered design system (should its scope be expanded) would be so extensive so as to stifle creativity in developing fields.

Having generally identified the rationales for why intellectual property should be protected in this section, the discussion now proceeds to the specific minimum standards set by international intellectual property treaties for the protection of industrial designs.

\subsection{International Intellectual Property Treaties}

International intellectual property treaties set minimum legal standards for member countries to observe and determine the degree of flexibility legislators have in setting the scope of protection.

The international standards for design protection in international treaties are few in number and tend to be vague. The difficulty in prescribing specific legal standards for industrial designs arises from the complexity of categorising the concept. Industrial designs are conceptually flexible enough to fit within several intellectual property frameworks. ${ }^{97}$ Moreover, modern reconceptualisations of industrial designs are only further exacerbating this flexibility. ${ }^{98}$ However, the same flexibility that allows them to fit within the different frameworks is also an indication that perhaps they do not really belong within any. ${ }^{99}$ Although there have been several international treaties on intellectual property, it is evident from the dearth of provisions on industrial designs that clarification regarding their categorisation has been essentially avoided.

\footnotetext{
${ }^{97}$ Orit Afori "Reconceptualising Property in Designs" (2008) 25 Cardozo Arts \& Ent L J 1105 at 1117.

${ }^{98}$ See the discussion in Section 2.2: The Role of the Industrial Designer.

${ }^{99}$ Afori, above n 97, at 1117.
} 


\subsubsection{Paris Convention}

The first major international treaty on the subject of intellectual property protection was the Paris Convention for the Protection of Industrial Property ("Paris Convention"). ${ }^{100}$

In 1880, the French Government proposed the establishment of an international union for the protection of industrial property. The proposal was in response to a series of resolutions made at international conferences, which began in Vienna in 1873. The Paris Convention was eventually adopted in $1883 .^{101}$

Initially the Paris Convention did not include industrial designs as a subject of protection. Industrial designs were included in the definition of industrial property, ${ }^{102}$ in the Hague revision conference in $1925 .{ }^{103}$ Then, a specific obligation to protect industrial designs, ${ }^{104}$ was added in the Lisbon revision conference in $1958 .{ }^{105}$ However, this provision is extremely limited. It states only that "industrial designs shall be protected in all the countries of the union". ${ }^{106}$ This provision does not define "industrial design", nor does it explicitly state how an industrial design should be protected or what should be the minimum term of protection. Nevertheless, industrial designs are subject to the national treatment clause in the Paris

\footnotetext{
${ }^{100}$ Paris Convention for the Protection of Industrial Property (20 March 1883, as revised at Brussels 1990, Washington 1911, The Hague 1925, London 1934, Lisbon 1958, Stockholm 1967, amended 28 September 1979). ${ }^{101}$ Philippe Baechtold, Tomoko Miyamoto and Thomas Henninger "International patent law: Principles, major instruments and institutional aspects" in Daniel Gervais (ed) International Intellectual Property: A Handbook of Contemporary Research (Edward Elgar Publishing Ltd, Cheltenham, 2015) 37 at 42.

102 See Paris Convention, above n 100, at art 1.

103 Sam Ricketson The Paris Convention for the Protection of Industrial Property: A Commentary (Oxford University Press, 2015) at 479.

104 See Paris Convention, above n 100, at art $5^{\text {quinquies }}$.

105 Ricketson, above n 103, at 479.

106 See Paris Convention, above n 100, at art $5^{\text {quinquies }}$
} 
Convention. Thus, whatever the protection for designs a Union member provides for its nationals must be provided to any other Union member. ${ }^{107}$

\subsubsection{Berne Convention}

The Berne Convention for the Protection of Literary and Artistic Works 1886 (Berne Convention) ${ }^{108}$ was the next major international treaty on intellectual property protection. The Berne Convention was chiefly concerned with promoting international copyright relations. ${ }^{109}$

The Berne Convention specifies the type of works that are eligible for copyright protection. Provisions for industrial designs and works of applied art were added by the Brussels Act 1948. ${ }^{110}$ However, neither "industrial designs" nor "works of applied art" is defined in the Berne Convention. Moreover, the Berne Convention does not set a minimum standard for the scope of protection, leaving it for individual countries to determine on their own. Article 2(7) of the Berne Convention states: ${ }^{111}$

Subject to the provisions of Article 7(4) of this Convention, it shall be a matter for legislation in the countries of the Union to determine the extent of the application of their laws to works of applied art and industrial designs and models, as well as the conditions under which such works, designs and models shall be protected...

\footnotetext{
${ }^{107} \mathrm{Ibid}$, at art 2.

${ }^{108}$ See The Berne Convention for the Protection of Literary and Artistic Works (9 November 1886, as revised at Paris 1986, Berlin 1908, Rome 1928, Brussels 1948, Stockholm 1967, Paris 1971, amended 28 September 1979). ${ }^{109}$ Laddie and others, above $\mathrm{n} 5$ at 269.

${ }^{110}$ Sam Ricketson and Jane Ginsburg "The Berne Convention: Historical and institutional aspects" in Daniel Gervais (ed) International Intellectual Property: A Handbook of Contemporary Research (Edward Elgar Publishing Ltd, Cheltenham, 2015) 3 at 18.

${ }^{111}$ Berne Convention, above n 108, at art 2(7).
} 
Article 7(4) does however, stipulate that for "works of applied art" the term of protection shall be "at least a period of 25 years". ${ }^{112}$ The absence of any further guidance in the Berne Convention, coupled with the fact that no definition is provided, has led to the incorporation of similarly ill-defined provisions pertaining to "works of applied art" in New Zealand's and China's respective copyright laws. Consequently, the courts have been tasked with defining the "works of applied art" category, and have had great difficulty establishing a workable test for its application. Nevertheless, in spite of the ambiguities in case law, it appears the courts in New Zealand and China have interpreted the "works of applied art" category as being wide enough to be applicable to some industrial designs. ${ }^{113}$

\subsubsection{TRIPS Agreement}

The Agreement on Trade-Related Aspects of Intellectual Property Rights (TRIPS) is a more comprehensive international treaty than the Berne Convention, as it covers all areas of Intellectual Property. ${ }^{114}$ TRIPS came into effect on 1 January 1995, and is built on the foundation of both the Paris Convention and the Berne Convention, the full acquis of which are incorporated by reference. ${ }^{115}$

TRIPS has gone some way in setting out the minimum standard for industrial design protection. ${ }^{116}$ However, there are only two articles in TRIPS that are relevant to industrial designs, and these are both brief. Moreover, much of the requirements and guidance set out in

\footnotetext{
112 Ibid, at art 7(4).

${ }^{113}$ For how the category has been interpreted in New Zealand - see the discussion below in Section 3.3.3.2: Applicable categories. For China - see the discussion in Section 4.1.1: Applicable categories.

${ }^{114}$ See Agreement on Trade-Related Aspects of Intellectual Property Rights (15 April 1994, entered into force 1 January 1995).

${ }^{115}$ For reference to Paris Convention, see ibid, at art 2(1); for reference to Berne Convention, see ibid, at art 9(1). 116 See ibid, at arts 25 and 26.
} 
these articles is ambiguous. For example, TRIPS stipulates that industrial designs shall be "independently created", as well as "new or original". ${ }^{117}$ Anna Kingsbury illustrates how this requirement is ambiguous. She explains that the inclusion of the words "independently created" in Article 25(1) of TRIPS, means that "original" can be understood in one of two ways. First, "independently created" can be read as qualifying the word "original". As in, a design is original if it is independently created, or in other words, not copied from somebody else. ${ }^{118}$ This reading suggests a low threshold for protection, resembling that of copyright law. ${ }^{119}$ Alternatively, Kingsbury explains that "independently created" can be read as a separate requirement. In which case, a design will have to be new or original in addition to being independently created. ${ }^{120}$ This interpretation suggests a significantly higher threshold for protection.

Daniel Gervais suggests that the prescribed minimum standard in TRIPS was not intended to dictate a universal international standard. Instead, negotiators settled on the existing, arguably rather broad, requirement in acknowledgment of the fact that there are different practices in different countries. ${ }^{121}$ Gervais explains that the existing standard is a compromise. Some countries require protectable designs to be new, others require them to be original and some require them to be both new and original. Thus, the words "new or original" were decided upon in TRIPS as the formulation that best accommodates the different practices. ${ }^{122}$

\footnotetext{
117 See ibid, at art 25(1).

118 Kingsbury, above n 58, at 388.

${ }^{119}$ See discussion below in Section 3.3.3.1: Originality requirement.

${ }^{120}$ Kingsbury, above n 58, at 388 .

${ }^{121}$ Daniel Gervais The TRIPS Agreement: Drafting History and Analysis (3rd ed, Thomson Reuters, London, $2008)$ at 327.

122 Ibid.
} 


\subsubsection{Hague Agreement}

Another major international agreement relevant to industrial designs is the Hague Agreement

Concerning the International Deposit of Industrial Designs ("Hague Agreement"). ${ }^{123}$ The Hague Agreement established a single international registration system for industrial designs. It came into force on 1 June 1928. The registration system is only for member states. Neither New Zealand nor China are members.

\subsubsection{Comprehensive and Progressive Agreement for Trans-Pacific Partnership and the Regional Comprehensive Economic Partnership}

The Comprehensive and Progressive Agreement for Trans-Pacific Partnership (CPTPP) ${ }^{124}$ is a treaty that New Zealand signed, along with 10 other countries, ${ }^{125}$ on 8 March 2018. The CPTPP was borne out of the negotiations that were originally carried out between these 11 countries and the United States for the Trans-Pacific Partnership Agreement (TPPA).

After the United States pulled out of these negotiations on 23 January 2017, the remainder of the negotiating parties continued, resulting in a similar agreement, namely the CPTPP. ${ }^{126}$ The majority of the TPPA is incorporated by reference, ${ }^{127}$ including several provision that were of concern to New Zealanders during the TPPA negotiations. Some of these provisions have been

\footnotetext{
${ }^{123}$ Hague Agreement Concerning the International Deposit of Industrial Designs (6 November 1925, entered into force 1 June 1928, as revised at London 1934, The Hague 1960, Monaco 1961, Stockholm 1967, amended 28 September 1979, and revised in Geneva 1999).

${ }^{124}$ Comprehensive and Progressive Agreement for Trans-Pacific Partnership (signed 8 March 2018, entered into force 30 December 2018).

125 Other signatories to the agreement are: Australia, Brunei, Canada, Chile, Japan, Malaysia, Mexico, Peru, Singapore and Vietnam.

126 The Ministry of Foreign Affairs and Trade Comprehensive and Progressive Agreement for Trans-Pacific Partnership: National Interest Analysis (2018) at 13.

${ }^{127}$ See CPTPP, above n 124, at art 1.
} 
suspended, ${ }^{128}$ but the provision specifically concerning industrial designs is not one of those suspended. Thus, the following TPPA provision has been incorporated into the CPTPP: ${ }^{129}$

The Parties recognise the importance of improving the quality and efficiency of their respective industrial design registration systems, as well as facilitating the process of cross-border acquisition of rights in their respective industrial design systems, including giving due consideration to ratifying or acceding to the Geneva Act of the Hague Agreement Concerning the International Registration of Industrial Designs, done at Geneva, July 2, 1999.

The CPTPP entered into force for New Zealand and five other signatories on 30 December 2018.

While the United States-led TPPA was being negotiated, China initiated its own multilateral fair trading agreement for the Asia-Pacific region, namely the Regional Comprehensive Economic Partnership (RCEP). ${ }^{130}$ RCEP is China's alternative solution to the noodle bowl problem that the TPPA sought to resolve. The noodle bowl is a metaphor for the multiple bilateral fair trading agreements established in the region during the 2000s. ${ }^{131}$ The primary objective of both agreements was arguably the same, that is to introduce a single coherent agreement into a region currently inefficiently entangled with multiple agreements encompassing different obligations to different countries. ${ }^{132}$

\footnotetext{
${ }^{128}$ Ibid, at art 2.

${ }^{129}$ Trans-Pacific Partnership Agreement (signed 4 February 2016, not in force), art 18.56.

130 Jeffrey Wilson "Mega-Regional Trade Deals in the Asia-Pacific: Choosing between the TPP and RCEP?" (2015) 45 J Contemp Asia 345 at 349.

${ }^{131}$ Ibid, at 348 .

${ }^{132}$ Ibid.
} 
With respect to industrial designs, unlike the TPPA, the Guiding Principles and Objectives for Negotiating the RCEP ${ }^{133}$ do not mention either the Hague Agreement or industrial designs. There is only the following clause with respect to intellectual property generally: ${ }^{134}$

The text on intellectual property in the RCEP will aim to reduce IP-related barriers to trade and investment by promoting economic integration and cooperation in the utilization, protection and enforcement of intellectual property rights.

This clause is vague leaving scope for interpretation, but it is arguable that signing up to the Hague Agreement would be a step toward removing IP-related barriers.

Further discussion as to whether or not it would be beneficial for New Zealand to sign the Hague agreement is provided in Chapter 6. ${ }^{135}$ The discussion in this chapter now proceeds to the specific legal protection mechanisms used to protect industrial designs in New Zealand.

\subsection{Domestic Law in New Zealand Most Relevant to Industrial Designs}

This section identifies the different laws that can be used to protect industrial design in New Zealand. The discussion focuses on the most common mechanisms used, namely copyright and registered designs, with some brief discussion of less important ones. This is followed by an overview of New Zealand competition law. As noted in the previous section, an intellectual property regime should balance the interests of creators on the one hand with the interest of greater society on the other. The final section of this chapter therefore identifies the extent to which intellectual property rights are affected by competition law in New Zealand.

\footnotetext{
133 Guiding Principles and Objectives for Negotiating the Regional Comprehensive Economic Partnership (endorsed by Regional Comprehensive Economic Partnership Ministers 30 August 2012, Negotiations launched 20 November 2012).

${ }^{134}$ Ibid, cl v.

${ }^{135}$ See Section 6.2.5: Acceding to the Hague Agreement (international design register).
} 


\subsubsection{Trade marks and patents}

Patents are typically considered to be the strongest form of intellectual property protection, but industrial designs do not usually qualify for patent protection.

Patents protect inventions. ${ }^{136}$ Most industrial designs, however, are not inventions, but, rather, variations of past inventions. An industrial design does not need to entail something entirely new, sometimes the variations can be a substantially inventive step. In other words, industrial designs are not only patentable when they embody a novel solution to a technical problem, but also when they embody a significant improvement to an existing solution. ${ }^{137}$ This typically occurs where the variation in design concerns more than just aesthetic features, and usually requires significant functional modifications. Consider the design of the Avtomat Kalashnikov (AK-47) assault rifle as an example. Although there were automatic assault rifles available prior to the AK-47, it was patentable because it embodied a significant improvement to the solution offered by earlier designs. That is, it essentially proved more lethal than other automatic assault rifles. ${ }^{138}$

Of course, less high-tech industrial designs than the AK-47 have been patented in the past. In the mid-nineteenth century, for example, patents were highly utilised for mass-produced designs of what are considered today ordinary everyday products, such as furniture. ${ }^{139}$ Moreover, even after those patents were issued, subsequent patents were later obtained for significant variations or modifications. Long after the first chair was constructed, patents were

\footnotetext{
136 David Musker "The Overlap between Patent and Design Protection" in Neil Wilkof and Shamnad Basheer (eds) Overlapping Intellectual Property Rights (Oxford University Press, Oxford, 2012) 23 at 35.

${ }^{137}$ Ibid, at 42.

138 Alice Rawsthorn "Designers Versus Inventors" The New York Times (online ed, New York, 21 April 2013).

${ }^{139}$ Dan Hunter and Suzannah Wood "The Laws of Design in the Age of Mechanical Reproduction" (2016) 37 Adel L Rev 403 at 413.
} 
still being obtained for variations and modifications to chair designs. Examples include different spring-operated chairs, chairs with different adjustable components, such as the levered office chair, and special purpose chairs, such as the barber's or dentist's chair. Today, most significant variations and modifications for the chair, as well as many other products, have already been designed. ${ }^{140}$ Despite this, new designs are constantly being developed, but the novelty in most of these designs is limited to non-functional aspects and often solely to aesthetics. These design features are nonetheless valuable, and so design registration/design patent systems, ${ }^{141}$ were established in recognition of this.

The trade mark is another mode of intellectual property protection that is unavailable to typical industrial designs. Industrial designs that may be protected by a trade mark are recognised by consumers as being a distinctive feature of a particular trader. ${ }^{142}$ Certain industrial designs may potentially be registered as shape trademarks. Generally, however, consumers do not readily perceive shapes as being associated with particular traders. ${ }^{143}$ Thus, in order to be registered as a trade mark, it is often necessary to establish as a matter of fact that the shape has acquired such distinctiveness. ${ }^{144}$ It is very difficult to acquire sufficient distinctiveness. This was evident in Colgate Palmolive Company $v$ Beecham Group Plc, ${ }^{145}$ in which Laddie J's following statement in Yakult Honsha KK's Trade Mark Application was noted: ${ }^{146}$

The fact that a container or [device] is unusual or attractive does not, per se, mean that it will be taken by the public as an indication of origin. The relevant question is not whether

\footnotetext{
140 Ibid, at 415 .

${ }^{141}$ New Zealand's registered design system is discussed below in Section 3.3.4: Registered designs. China's design patent is discussed in Section 4.2.3: Design patents.

${ }^{142}$ See Fredco Trading Ltd v Miller (2006) 11 TCLR 751 at 762.

${ }^{143}$ Rob Batty "Shape trade marks" (2014) NZLJ 133 at 133.

144 Ibid.

${ }^{145}$ Colgate Palmolive Company v Beecham Group Plc [2002] IPONZ TM Nos 243835 \& 313845.

146 Yakult Honsha KK's Trade Mark Application [2001] RPC 39, at [10].
} 
... it is of memorable appearance, but whether by itself its appearance would convey trade mark significance to the average customer.

Laddie $\mathbf{J}$ further explains that an industrial design having sufficient novelty for design registration does not mean that it has the distinctiveness required for a trade mark. ${ }^{147}$ For this reason, few industrial designs are registered as trade marks. Those that are registered are usually famous marks that have had a long market presence. ${ }^{148}$ The scope of protection for such marks, however, is quite limited. This was evident in The Coca-Cola Company v Frucor Soft Drinks Limited case. ${ }^{149}$ Although Wylie J accepted that Coca-Cola's contour bottle was a trade mark, ${ }^{150}$ he held that the defendant's Carolina bottle was sufficiently different and thus there was no infringement. ${ }^{151}$ Moreover, Wylie J noted that the defendant's other marks, such as their names and logos, made the difference even more obvious. ${ }^{152}$ Thus, making it unlikely that any consumers would misapprehend the origins of the product. ${ }^{153}$ The effect of the combination sign was not necessary to decide the case, as the shape of the bottle in itself was held to be sufficiently different. It seems, however, that even if the bottles had been the same, so long as the overall appearance of the bottles was sufficiently different, by virtue of the marks as a combination, there would be no infringement. This can be inferred from the test that Wylie $\mathbf{J}$ applies. He says that when making the comparison "the marks have to be considered as a whole ... because the average consumer normally perceives a mark as a whole .... It is the totality of impression ... which is important." 154

\footnotetext{
${ }^{147}$ Ibid.

${ }^{148}$ For example, Coca Cola has registered its contour bottle as a trade mark.

149 The Coca-Cola Company v Frucor Soft Drinks Limited [2013] NZHC 3282.

150 Ibid, at [141].

151 Ibid, at [188].

152 Ibid, at [189].

153 Ibid, at [190].

154 Ibid, at [161].
} 
Another limitation of trade marks in protecting industrial designs is the fact that they only protect the industrial designs in a particular market. ${ }^{155}$

Aside from being of limited use in protecting industrial designs, as noted above, few industrial designs are sufficiently distinctive to acquire trade mark protection in the first place. The same is true for patents. Due to the very low number of industrial designs that are capable of acquiring patent or trade mark protection, these legal mechanisms are not further examined.

\subsubsection{Passing off and the Fair Trading Act 1986}

The tort action of passing may protect intellectual property, including industrial designs if they constitute product "get-up". 156

The elements of passing off commonly cited by New Zealand courts, were described by Lord Oliver of Aylmerton in Reckitt \& Colman Products Ltd v Borden: ${ }^{157}$

...in terms of the elements which the plaintiff in such an action has to prove in order to succeed... First, he must establish a goodwill or reputation attached to the goods or services which he supplies in the mind of the purchasing public by association with the identifying 'get-up' (whether it consists simply of a brand name or a trade description, or the individual features of labelling or packaging) under which his particular goods or services are offered to the public, such that the get-up is recognised by the public as distinctive specifically of the plaintiff's goods or services. Second, he must demonstrate a misrepresentation by the defendant to the public (whether or not intentional) leading or

\footnotetext{
${ }^{155}$ Alan Nemes and Anna Carboni “Overlapping Rights in Designs, Trademarks and Trade Dress" in Neil Wilkof and Shamnad Basheer (eds) Overlapping Intellectual Property Rights (Oxford University Press, Oxford, 2012) 251 at 261.

${ }^{156}$ Ian Finch (ed) James and Wells Intellectual Property Law in New Zealand $3^{\text {rd }}$ ed Thomson Reuters, Wellington, 2017) at 1150.

${ }^{157}$ Reckitt \& Colman Products Ltd v Borden Inc [1990] 1 All ER 873 (HL) at 880.
} 
likely to lead the public to believe that goods or services offered by him are the goods or services of the plaintiff...Third, he must demonstrate that he suffers or... that he is likely to suffer damage by reason of the erroneous belief engendered by the defendant's misrepresentation that the source of the defendant's goods or services is the same as the source of those offered by the plaintiff.

The requirement of goodwill or reputation associated with the "get-up" by the purchasing public often precludes industrial design owners from having recourse to the tort action of passing off. In order for an industrial design to be recognised as "get-up" by the purchasing public, it needs to be sufficiently distinctive. ${ }^{158}$ This will depend on the extent of use as well as inherent distinctiveness. ${ }^{159}$ As such, it is mostly well-established industrial design owners that have recourse under passing off.

Proceedings under Section 9 of the Fair Trading Act 1986 can be brought alongside an action under the tort of passing off. Section 9 provides: "No person shall, in trade, engage in conduct that is misleading or deceptive or is likely to mislead or deceive." In practice, when a breach of section 9 is established in relation to goods, section 10 is also breached. ${ }^{160}$ Section 10 reads: No person shall, in trade, engage in conduct that is liable to mislead the public as to the nature, manufacturing process, characteristics, suitability for a purpose, or quantity of goods."

Although action can be brought under the Fair Trading Act and the tort of passing off simultaneously, as both causes of action are concerned with misrepresentation, there is a

\footnotetext{
${ }^{158}$ Finch, above n 156, at 1149.

${ }^{159}$ Ibid, at 1150.

${ }^{160}$ Ibid, at 1198.
} 
significant difference between them. ${ }^{161}$ The tort of passing off is directed at protecting one's intangible property right in their goodwill and reputation, whereas the Fair Trading Act is directed at protecting the consumer. ${ }^{162}$ This does not however preclude a rival trader from bringing action under the Fair Trading Act. Cooke P in Taylor Textile Services Auckland Ltdv Taylor explained: ${ }^{163}$

...it is clear that, although the Act is primarily consumer-protection legislation, a rival trader may enforce s 9 and is indeed the usual applicant. In this way the Act operates partly for the benefit of the ethical trader."

Alleged infringing conduct will generally not be established unless there is misrepresentation. ${ }^{164}$ With respect to "get up", misrepresentation, is unlikely to occur unless the relevant section of the public is familiar with it. ${ }^{165}$ Thus a significant reputation in the "getup" will usually need to be established. In Godfrey Hirst NZ Ltd v Cavalier Bremworth Ltd, Justice Wild summed up the approaches of New Zealand courts in determining what the relevant section of the public is: ${ }^{166}$

All the formulations seem to us to encompass most of the public, where the representation is made to the public at large, or most of the consumers in any class specifically targeted.

Similarly to the tort of passing off, the Fair Trading Act will usually only be utilised by those industrial designers who have a well-established reputation. Most industrial designers however, only have recourse to copyright and registered design protection. These protections are the focus of this study. Each is discussed below.

\footnotetext{
161 Ibid, at 1230.

162 Ibid, at 1231 .

${ }^{163}$ Taylor Textile Services Auckland Ltd v Taylor [1988] 2 NZLR 1 at 39.

${ }^{164}$ Finch, above n 156, at 1208.

165 Ibid, at 1220

${ }^{166}$ Godfrey Hirst NZ Ltd v Cavalier Bremworth Ltd [2014] NZCA 418 at [43].
} 


\subsubsection{Copyright}

In New Zealand, as in all countries that are signatories to the Berne Convention, copyright protection is free and automatic, provided that the work comes within one of the categories listed in the Copyright Act 1994, and meets the appropriate originality threshold. ${ }^{167}$ The next section explains the degree of originality required and then the discussion proceeds to the categories that are relevant to industrial designs.

\subsubsection{Originality requirement}

Any work that comes within any of the categories set out in the Copyright Act must be original in order to acquire protection. The meaning of "original" is not defined in the Copyright Act, which provides only that: ${ }^{168}$

A work is not original if-

(a) it is, or to the extent that it is, a copy of another work; or

(b) it infringes the copyright in, or to the extent that it infringes the copyright in, another work.

The concept of originality has otherwise been established by case law. In Henkel KgaA v Holdfast New Zealand Ltd, ${ }^{169}$ Tipping J explained: “To be original for copyright purposes the work must originate from its author and must be the product of more than minimal skill and labour." 170

With respect to the threshold, Tipping J stated the following: ${ }^{171}$

\footnotetext{
${ }^{167}$ See Copyright Act 1994 (NZ), s 14.

${ }^{168}$ Copyright Act 1994 (NZ), s 14(2).

${ }^{169}$ Henkel KgaA v Holdfast New Zealand Ltd [2007] 1 NZLR 577 (SC).

${ }^{170}$ Ibid, at [37].

${ }^{171}$ Ibid, at [38].
} 
The threshold for originality is a low one and it can be material for other purposes how original the work is; that is, how much skill and labour has gone in to its creation. In general terms the greater the originality, the wider will be the scope of the protection which copyright affords and vice versa.

The assessment of the degree of originality is thus a matter that is decided on a case by case basis. It is noteworthy that, like the United Kingdom, New Zealand does not require evidence of creativity for a work to be sufficiently original for copyright. ${ }^{172}$

\subsubsection{Applicable categories}

Section 14 sets out the categories of work that can be protected under the Copyright Act. One such category is "artistic work". The definition in section 2 of the Act provides:

artistic work:

(a) means-

(i) a graphic work, photograph, sculpture, collage, or model, irrespective of artistic quality; or

(ii) a work of architecture, being a building or a model for a building; or

(iii)a work of artistic craftsmanship, not falling within subparagraph (i) or subparagraph (ii) ...

"Graphic work" is further defined in Section 2 of the Copyright Act as including: "(a) any painting, drawing, diagram, map chart, or plan; and (b) any engraving, etching, lithograph, woodcut, print, or similar work." This broad definition of "graphic work" Kingsbury explains is "significant in offering protection to a wide range of industrial design products, including functional products." ${ }^{173}$ Some industrial designs will also be protected under copyright as

\footnotetext{
${ }^{172}$ In contrast, copyright in the United States requires a "minimal creative spark" - see Feist Publications Inc v Rural Telephone Service Co Inc 499 US 340 (1991) at [1296].

${ }^{173}$ Anna Kingsbury Intellectual Property Law in New Zealand (Wolters Kluwer, The Netherlands, 2017) at 23.
} 
sculptures. Section 2 of the Copyright Act further defines "sculpture" as including "a cast or model made for purposes of sculpture". ${ }^{174}$ Sample designs or prototypes of products can be protected as models. ${ }^{175}$

"Work of artistic craftsmanship" is particularly important for industrial design, ${ }^{176}$ but is not further defined in the Copyright Act 1994. The following section examines in more detail this sub-category of "artistic work".

\subsection{Work of artistic craftsmanship}

Article 7(4) of the Berne Convention states that for 'works of applied art' "the term of protection ... shall last at least until the end of a period of twenty-five years from the making of such a work." The Copyright Act describes a work of applied art as a "work of artistic craftsmanship", ${ }^{177}$ but provides no definition of the term.

In New Zealand, the issue of what constitutes "artistic craftsmanship" was considered by the High Court in the case of Bonz Group (Pty) Ltd v Cooke ('Bonz Group'), ${ }^{178}$ where Tipping J stated that, in order for a work to be regarded as one of "artistic craftsmanship", the work must have some artistic quality. ${ }^{179}$ Moreover, the author of such a work must be both a craftsman and an artist. ${ }^{180} \mathrm{~A}$ craftsman is "a person who makes something in a skilful way and takes justified pride in their workmanship", while an artist is "a person with creative ability who

\footnotetext{
${ }^{174}$ For example, wooden models used in the manufacture of Frisbees were held to be 'sculptures.' See Wham-O MFG Co v Lincoln Industries Ltd [1984] 1 NZLR 641.

${ }^{175}$ See, for example Thornton Hall Manufacturing Ltd v Shanton Apparel Ltd (No 2) [1989] 1 NZLR 234.

176 Kingsbury, above n 173, at 23.

177 See Copyright Act 1994 (NZ), s 2.

${ }^{178}$ Bonz Group (Pty) Ltd v Cooke [1994] 3 NZLR 216.

${ }^{179}$ Ibid, at [224].

${ }^{180}$ Ibid.
} 
produces something which has aesthetic appeal". ${ }^{181}$ Although this is a leading New Zealand case with regard to the issue of what constitutes "artistic craftsmanship", it is not particularly helpful, as it is rather vague in scope. This is evident from the type of things that have qualified under the category. In Bonz Group, the works held to be "artistic craftsmanship" were handknitted sweaters. Then, more recently in 2015 , the entire setup of a haunted house was held to be a work of artistic craftsmanship. ${ }^{182}$

A useful working definition of "artistic craftsmanship" is difficult to establish. A legal practitioner specialising in intellectual property (legal practitioner ' $I$ ') made the following comment, in regard to the interpretation of artistic craftsmanship established in Bonz Group:

I am not sure I agree. I do not see why the author has to be both a craftsman and an artist, I mean, what does that really mean, anyway? These sorts of things are almost impossible to apply properly in a real situation. They are sort of hypothetical anyway. I suppose it is useful, but you can have lots of ... different interpretations.

It was not always so difficult, however, to recognise a "work of artistic craftsmanship". In fact, it is easy to trace the point in history where "artistic craftsmanship" turned from being something relatively obvious, to something that is now much more difficult to identify precisely.

The first artist craftsman were perhaps the highly respected intellectual artists who distinguished themselves from humble artisans during the early Renaissance in the late fourteenth century. ${ }^{183}$ Until at least mid-eighteenth century, artist craftsman remained easily

\footnotetext{
181 Ibid.

${ }^{182}$ See Dreamtech Designs \& Productions Pty Limited v Clownfish Entertainment Limited [2015] NZHC 1143.

${ }^{183}$ Erin Campbell "Artisans, Artists and Intellectuals" (2000) 23 Art History 622 at 622.
} 
distinguishable from artisans and tended to be few in number. ${ }^{184}$ Moreover, artist craftsmen tended to serve a very limited clientele, usually only royalty and nobility. ${ }^{185}$ With the industrial revolution however, came the rise of machines, which sped up and simplified the manufacturing process. ${ }^{186}$ The designs of domestic products for the lower classes began to mimic the designs exclusively crafted for royalty and nobility. ${ }^{187}$ As machine capabilities advanced over time, it became more and more difficult to distinguish the designs of artist craftsmen from mass-produced designs.

Despite the difficulty, the law has attempted to distinguish artist craftsman from artisans or ordinary craftsmen. The first legislation to implicitly do so in the United Kingdom was the Engraving Copyright Act $1734 .{ }^{188}$ "Work of artistic craftsmanship" was first expressly referred to in the copyright law of the United Kingdom in the Copyright Act $1911 .{ }^{189}$ Interestingly, this was the same legislation that, as noted above, first excluded "artistic work that has been applied industrially" from the ambit of copyright protection. By this point in time, machine manufacture was already quite prevalent. So the question that needs to be asked is: what was considered to be the distinguishing characteristic of "work of artistic craftsmanship"?

Prima facie it would seem the distinguishing characteristic is that the "work of artistic craftsmanship" has to be "artistic". Although the words "irrespective of artistic quality" are used in the definition of "artistic work" in the Copyright Act 1994, these words are not used to qualify "work of artistic craftsmanship". 190

\footnotetext{
${ }^{184}$ Hunter and Wood, above n 139, at 411.

185 Ibid.

${ }^{186}$ Ibid, at 413.

${ }^{187}$ Ibid, at 412 .

188 Original engravings were typically embodied in the works of artist craftsman.

${ }^{189}$ See Copyright Act 1911 (Imp) 1 \& 2 Geo V c 46, s 35.

${ }^{190}$ Copyright Act 1994 (NZ), s 2(1).
} 
Craftsmanship that has "artistic quality" does not have to be "artistic in character". One design academic/industrial designer (academic 'D') stated:

To some, an artist might make something that is really desirable and quite remarkable, but not makeable on scale. Art, to me, has something that you are trying to say. Sometimes that will be defeated with high quality craft.

Another design academic (academic ' $C$ ') was also of the opinion that artistic craftsmanship is something very different from art:

An artist is making a commentary about politics and about society. That is not what an artist craftsman is doing. They are not political ... Most artists try to push a button and ask do you like me, do you hate me, or what do you hear from me?

Academic ' $\mathrm{C}$ ' further explained, with reference to the haunted house in Dreamtech Designs \& Productions Pty Limited v Clownfish Entertainment Limited (Dreamtech Designs): ${ }^{191}$

A haunted house is not an artwork. It is not a commentary. There would be a certain level of craftsmanship, if you were putting make-up on someone, in a movie. That is craft, but if you went and painted someone in some weird colour, to make some sort of statement, that is an artistic thing.

Taking all the above observations into consideration, it is noteworthy that one legal practitioner specialising in intellectual property (legal practitioner ' $\mathrm{K}$ ') was of the opinion that the interpretation of artistic craftsmanship in Bonz Group $^{192}$ serves as a reasonable guide:

I do not think that the "justified pride" addition is necessary, but otherwise I think this guide is reasonable. The requirement of "creative ability" is interesting, but perhaps it could be argued that if someone created a unique form from metal then that person could

\footnotetext{
${ }^{191}$ Dreamtech Designs \& Productions Pty Limited v Clownfish Entertainment Limited, above n 182.

${ }^{192}$ Bonz Group (Pty) Ltd v Cooke, above n 178, at [224].
} 
automatically be imbued with having a creative ability, regardless of whether or not they would identify themselves as being an artist.

Despite the apparent de-emphasis on "artistic character", all five judges in the United Kingdom case of George Hensher Limited v Restawile Upholstery (Lancs) Limited (Hensher) ${ }^{193}$ agreed that there still had to be some additional characteristic for "work of artistic craftsmanship", which was not required for other types of artistic works. Although there was no consensus as to what precisely the additional characteristic is, all five judges agreed that a "work of artistic craftsmanship" had to be appealing to the eye. Lord Simon explained that this, however, was not in itself sufficient, because there are things that can be appealing to the eye that are not artistic, such as a landscape. ${ }^{194}$ Thus, the distinguishing characteristic must be something other than eye appeal. Lord Simon and Lord Kilbrandon both suggested that what distinguished "work of artistic craftsmanship" was the intention of the creator to make such a work. ${ }^{195}$

The Australian High Court in Burge and others v Swarbrick (Burge), ${ }^{196}$ suggests that the author's intention is not a good indication of the nature of the work, stating: ${ }^{197}$ ...intentions may fail to be realised. Further just a few alleged inventors are heard to deny the presence of an inventive step on their part, so, it may be expected, will few alleged authors of works of artistic craftsmanship be heard readily to admit the absence of any necessary aesthetic element in their endeavours.

In New Zealand, Tipping J made a similar observation, in Bonz Group: ${ }^{198}$

\footnotetext{
${ }^{193}$ George Hensher Limited $v$ Restawile Upholstery (Lancs) Limited [1974] FSR 173, was a UK case that preceded Bonz Group (Pty) Ltd v Cooke and that was extensively referenced in the latter decision.

194 Ibid, at [195].

${ }^{195}$ Ibid, at [197] and [199].

${ }^{196}$ Burge and others v Swarbrick [2007] HCA 17.

${ }^{197}$ Ibid, at [64].

${ }^{198}$ Bonz Group (Pty) Ltd v Cooke, above n 178, at [223]-[224].
} 
I have some difficulty with the proposition that an author can have tried to be artistic and failed, yet the product, because this was the intention of the author, is nevertheless to be regarded as a work of artistic craftsmanship. I consider that the end result objectively viewed must have a significant bearing on the question. That is ... for a work to be one of artistic craftsmanship it must, in my judgment, have some artistic quality.

One argument is that authenticity is the required distinguishing characteristic of artistic quality. Authenticity is typically a concept that is more relevant to art work, where for example, a certain piece is perceived as particularly valuable due to having come from a particular source, or perhaps even just because it came into contact with a particular person. ${ }^{199}$ However, George Newman and Paul Bloom explain that this is not entirely unique to art. For example, the concept of authenticity may also be a value determinant in the case of certain consumer products where beliefs about history of creation underlie consumer preference. ${ }^{200}$ An example of this, is classical furniture, the manufacturers of which, often claim their designs to be traceable to some authentic lineage. ${ }^{201}$ Company ' $\mathrm{H}$ ' emphasised the authenticity of their designs:

We have got heritage. Our business was started in 1948 ... where everything was made with care ... using the best materials ... in the old fashion method. So because that is our background ... a lot of our pieces, which were designed in the 50s, 60s and 70s, are still being used ... sold and repurchased, and they are still as good today, as they were when they were designed 60-odd years ago.

A design-driven company (company ' $\mathrm{G}$ ') was also of the opinion that true design is about authenticity and longevity: "Design is something that is pressing and lasting, which people can enjoy and be nourished by for years and years."

\footnotetext{
${ }^{199}$ George Newman and Paul Bloom "Art and Authenticity: The Importance of Originals in Judgments of Value" (2012) 141 J Exp Psychol Gen 558 at 558.

200 Ibid, at 560.

${ }^{201}$ Hunter and Wood, above n 139, at 423.
} 
Hunter and Wood explain, however, that claims of authenticity are often misleading. Many furniture designs that are considered classical today were produced by different manufacturers at different points in time. Moreover, many were completely dropped from production in the 1960s and were not brought back into production until they became fashionable again in the mid-1990s. ${ }^{202}$

Essentially, as evident from Hunter's and Wood's observation, far too few designs would legitimately qualify as "work of artistic craftsmanship", if authenticity were the distinguishing characteristic of artistic quality.

Another argument is that the distinguishing characteristic of artistic quality is the profession. Company ' $G$ ' explained:

Most people say "I'm a designer what I do is design ... I'm not an artist or craftsman. Crafts, other people can make it. I haven't got time to do it, I'm a fancy designer." Well for a start you cannot design what you cannot make ... so ... you have to be a craftsman. You have to be an artist also, because if you say as a designer "I don't do that art stuff" then, where do you get your designs from? Where do you create your vocabulary with which you work? Where do you find your stories to tell? Where do you find what you believe in? All that stuff comes out of it.

Sam Ricketson and Uma Suthersanen point out that a "work of artistic craftsmanship" is usually obvious with respect to the works of jewellers, goldsmiths or leatherworkers. ${ }^{203}$ Although there is certainly less contention with regard to much of the work produced in these

\footnotetext{
202 Ibid, at 427.

${ }^{203}$ Sam Ricketson and Uma Suthersanen “The Design/Copyright Overlap: Is There a Resolution?” in Neil Wilkof and Shamnad Basheer (eds) Overlapping Intellectual Property Rights (Oxford University Press, Oxford, 2012) 159 at 184.
} 
professions, it is clear that not all their work is "artistic craftsmanship". Company ' $G$ ' considers this a modern-day problem:

A totally different process to a design process or an art process ... is what most people do. You end up doing this kind of keep them keen, one line joke, clever dick sort of stuff, which most people are indulging in because it is their way of trying to be seen and heard in the clamour of stuff going on, and it is bad design. You laugh at the joke once. It does not last. Design is not clever dick stuff ... design ... has to embrace that whole artdesign-craft continuum.

The reason why "artistic craftsmanship" is often obvious when it comes to the work of professionals such as jewellers, goldsmiths or leatherworkers was explained in Burge. Craftsmen such as jewellers typically have "considerable design choice relatively unconstrained by the function or utility of the article so produced."204 It was in fact the degree of functional/utilitarian constraint on the design that was held to be the determining factor in Burge: ${ }^{205}$

..."a work of artistic craftsmanship" does not turn on assessing any harmony between its visual appeal and its utility. The determination turns on assessing the extent to which the particular work's artistic expression, in its form, is unconstrained by functional consideration."

The vast utilitarian and functional considerations that go into the design of hull and deck mouldings for a yacht (the work in question in Burge), effectively leave the designer with very little creative design freedom. Thus, the Australian High Court determined that this was not a work of "artistic craftsmanship". ${ }^{206}$

\footnotetext{
${ }^{204}$ Burge and others $v$ Swarbrick, above n 196, at [75].

${ }^{205}$ Ibid, at [83].

${ }^{206}$ Ibid, at [85].
} 
While it is true that the design freedom of some professionals will be restricted by functional demands, this is not always the case. Lord Simon in Hensher provides an example of a blacksmith. Certainly, tasks such as shoeing a horse will hardly be, in anyone's mind, work of artistic craftsmanship. However, if they were to be tasked with making a wrought iron gate, this may well contend for the classification. ${ }^{207}$ Therefore, it is not simply a matter of profession. So what exactly is the difference between ordinary craftsmanship and "artistic craftsmanship"? Although it may seem obvious in some instances, what exactly makes it obvious?

To discern the distinguishing characteristic in "work of artistic craftsmanship", Lord Simon looked at historic developments, tracing the influence of the Arts and Crafts movement through a series of events, in the years leading up to the legislative introduction of the "work of artistic craftsmanship" classification. ${ }^{208}$

After having established that the Arts and Crafts movement was the influence for the classification, Lord Simon explained that one of the underpinning principles of the Arts and Crafts movement was that they saw artistic quality in everyday things. ${ }^{209}$ The empirical investigation conducted for this study revealed that this view is still prevalent among designers today. Moreover, "work of artistic craftsmanship" is not restricted to hand-crafted articles. Lord Simon pointed out that even distinguished Arts and Crafts advocate William Morris saw machines as useful for extinguishing irksome and unintelligent labour. ${ }^{210}$ This recognition, Lord Simon explained, was reflected in the specific word chosen for the legal category, namely "craftsmanship", as opposed to "handicraft". ${ }^{211}$

\footnotetext{
${ }^{207}$ George Hensher Limited v Restawile Upholstery (Lancs) Limited, above n 193, at [193].

208 Ibid, at [191].

209 Ibid.

${ }^{210}$ Ibid, at [192].

${ }^{211}$ Ibid.
} 
Artist craftsmen, explained academic 'C', "make useable objects, typically hand crafted, though not necessarily."

It is thus clear that the "work of artistic craftsmanship" classification is applicable to industrial designs. What is not clear, however, is precisely which industrial designs warrant this protection. We can deduce that it applies to industrial designs that have eye appeal, plus the distinguishing characteristic of artistic quality, which is, as discussed above, neither authentic lineage nor profession. It remains unclear what precisely the distinguishing characteristic of artistic quality in "work of artistic craftsmanship" is. It is a matter that is determined on a case by case basis.

\subsubsection{Term of protection}

Section 75 of the Copyright Act provides a special exception from protection of artistic work that has been applied industrially. Artistic work that is applied industrially is protected for only 16 years from the date that "more than 50 copies in 3 dimensions are made of the work, for the purpose of sale or hire". The same section prescribes the term of protection for "work of artistic craftsmanship", namely 25 years. ${ }^{212}$

These are significantly shorter terms than that provided for most other types of copyright works, which is 50 years plus the life of the work's creator, or 50 years from the year of creation/public release. ${ }^{213}$ The longer term of protection that is available to other types of

\footnotetext{
${ }^{212}$ Copyright Act 1994 (NZ), s 75

${ }^{213}$ See Copyright Act 1994 (NZ), s 22. Duration of protection is potentially subject to change under the CPTPP discussed below.
} 
works, such as fine arts or literary works, is ill-suited to most industrial designs. ${ }^{214}$ Such an extensive period of protection would unreasonably hinder competition, by preventing competitors from incorporating more functionally accommodating designs until long after their appeal to consumers, as well as the resultant competitive advantage, have become obsolete. ${ }^{215}$

The need to limit the term of protection for designs that have been applied industrially has been recognised since 1842. It was appreciated in the United Kingdom that some designs which were registrable under the Ornamental Designs Act 1842 were also potentially protected by the Models and Busts Act 1798 and later the Sculpture Copyright Act 1814. The solution to the overlap at the time was to exclude industrial designs from the much longer protection provided by the copyright statutes. ${ }^{216}$ Subsequent legislation in the United Kingdom followed suit, including the Copyright Act 1911, which distinguished an industrial design as one that was intended to be applied industrially by its author. ${ }^{217}$ Two years later this provision was adopted in New Zealand in the Copyright Act $1913 .{ }^{218}$ It was later repealed, as recommended by the New Zealand Copyright Commission. In its 1959 report presented to the House of Representatives by leave, the Commission expressed concern that the provision was effectively entirely dependent on the intention of the author, a variable that it considered could not be determined satisfactorily. ${ }^{219}$ After the repeal, dual protection for industrial designs was once again possible in New Zealand.

\footnotetext{
${ }^{214}$ Note, a longer term may be more appropriate for some industrial designs. The United Kingdom has recently re-extended the term of protection. The reasons are discussed below.

215 Afori, above n 97, at 1148 .

${ }^{216}$ Laddie, Prescott and Vitoria, above n 59, at 1047.

${ }^{217}$ Copyright Act 1911 (Imp) 1 \& 2 Geo V c 46, s 22.

218 Copyright Act 1913 (NZ), s 30.

${ }^{219}$ Copyright Committee Report Presented to the House of Representatives (NZ, 1959) at 115.
} 
Dual protection was revived in the United Kingdom under the Designs Copyright Act 1968, ${ }^{220}$ but the term of copyright protection for a "work of art applied industrially" was reduced in order to align it with the shorter term provided for registered designs and patents (16 years at the time). ${ }^{221}$ This approach was followed in New Zealand. ${ }^{222}$

The term of protection was recently re-extended in the United Kingdom however, by virtue of the Copyright (Amendment) Regulations 2016, which amended the Copyright, Design and Patents Act 1988. The amendment was primarily the product of the United Kingdom's efforts to align their copyright law with other members of the European Union. Other reasons which were identified in the consultation process, included the need to safeguard certain industries, such as classical furniture, and to encourage more long-term investment in design. ${ }^{223}$ Indeed, there are exceptions to the basic rationale noted above that industrial designs do not require a long period of protection. ${ }^{224}$ Classical furniture appears to be one of the least contested examples of such an exception. Insight as to what makes classical furniture different to more ordinary industrial designs was provided by a New Zealand based furniture design company (company 'H'):

Everything we do has to be of good quality, has to be of the best material ... and it must have ... longevity. We are not interested in disposable, fast furniture. So we make sure that every product ... is well made, thoughtfully made ... and original.

\footnotetext{
${ }^{220}$ Design Copyright Act 1968 (UK).

${ }^{221}$ Laddie, Prescott and Vitoria, above n 59, at 187.

${ }^{222}$ See Industrial Property Advisory Committee The Law of Copyright as it Applies in New Zealand to Industrial Designs (Report to the Minister of Justice 1983) at [3.3].

${ }^{223}$ Intellectual Property Office Call for evidence: Transitional provisions for repeal of section 52 of the Copyright, Designs and Patents Act 1988 (2013) at 8.

${ }^{224}$ When the reduction of term for "artistic work that has been applied industrially" was recommended, the Industrial Property Advisory Committee acknowledged that further study was necessary for arriving at protection laws that would serve the interests of designers in all fields as well as the public interest - see The Law of Copyright as it Applies in New Zealand to Industrial Designs, above n 221, at [4.5].
} 
The effect of the amendment was the repeal of Section 52 of the Copyright, Designs and Patents Act 1988, which was the provision that restricted copyright protection of industrial designs to 25 years. Thus, as of 28 July 2016, industrial designs that fall within one of the classifications of artistic work protected by copyright, receive the full term of copyright protection, namely the natural life of the creator, plus 70 years. ${ }^{225}$

Since the signing of the TPPA, it is likely that amendments will be made to the Copyright Act 1994. The TPPA prescribed a term of 70 years in addition to natural life. ${ }^{226}$ The Comprehensive and Progressive Agreement for Trans-Pacific Partnership Amendment Act 2018 mandates that life plus 50 years be replaced with life plus 70 years. ${ }^{227}$ However this provision is among those that have been suspended, ${ }^{228}$ for the time being, in the Trans-Pacific Partnership Agreement (CPTPP) Amendment Act 2018. ${ }^{229}$ Moreover, there is no proposed amendment to Section 75 of the Copyright Act. Therefore, there is no indication, at least at this stage, that New Zealand will be following the United Kingdom's approach in regard to the term of protection for industrial designs.

Should New Zealand choose to extend copyright protection for industrial designs, however, such an amendment would not be in breach of the Berne Convention. The Berne Convention states: ${ }^{230}$

\footnotetext{
225 Call for evidence: Transitional provisions for repeal of section 52 of the Copyright, Designs and Patents Act 1988 , above n 222, at 5.

${ }^{226}$ TPPA, n 129, at art 18.63.

227 The Comprehensive and Progressive Agreement for Trans-Pacific Partnership Amendment Act 2018 (NZ), s $5(1)$.

${ }^{228}$ See CPTPP, above $\mathrm{n} 124$, at art 2 and annex 7(g).

${ }^{229}$ See Trans-Pacific Partnership Agreement (CPTPP) Amendment Act 2018 (NZ), s 6.

${ }^{230}$ Berne Convention, above n 108, at art 2(7).
} 
... it shall be a matter for legislation in the countries of the Union to determine the extent of the application of their laws to works of applied art and industrial designs and models, as well as the conditions under which such works, designs and models shall be protected.

\subsubsection{Scope of protection}

What constitutes infringement indicates the scope of copyright protection, and the scope is an important consideration in determining the adequacy of protection.

Copyright infringement occurs whenever someone does any of the acts listed in Section 16 of the Copyright Act in respect of a copyright work, without permission from the copyright holder. Infringement can be direct or indirect and can occur with respect to the work as a whole or any substantial part of it. ${ }^{231}$

The most common form of infringement is by copying. ${ }^{232}$ "Copying" is defined in the Copyright Act as: 233

...reproducing, recording, or storing the work in any material form (including digital form), in any medium and by any means; and...includes, in relation to an artistic work, the making of a copy in 3 dimensions of a two-dimensional work and the making of a copy in 2 dimensions of a three dimensional work...

The test for infringement by copying was set out by the Court of Appeal in Wham-O Manufacturing $v$ Lincoln Industries Ltd. ${ }^{234}$ The following elements must be satisfied to establish that copying by reproduction has occurred: ${ }^{235}$

\footnotetext{
${ }^{231}$ Copyright Act 1994 (NZ), s 29.

${ }^{232}$ Kingsbury, above n 173, at 63.

${ }^{233}$ Copyright Act 1994 (NZ), s 94.

${ }^{234}$ Wham-O MFG Co v Lincoln Industries Ltd, above n 173, at 641.

${ }^{235}$ Ibid, at 666.
} 
(a) The reproduction must be either of the entire work or of a substantial part.

(b)There must be sufficient objective similarity between the infringing work and the copyright work, or a substantial part thereof.

(c)There must be some causal connection between the copyright work and the infringing work. The copyright must be the source from which the infringing work is derived.

What is a substantial part is generally assessed by courts in terms of the quality of what has been reproduced rather than the quantity. ${ }^{236}$ In Bonz Group, Tipping J explained that "the question whether a substantial part of the copyright work has been taken is one of fact and degree." 237

Even where there has been a substantial part taken however, it is still necessary that overall the allegedly infringing work is objectively similar to the copyright protected work. Thus, it is essentially a question of impression for the courts. ${ }^{238}$ In Thornton Hall Manufacturing Ltd v Shanton Apparel (No 2) Hillyer J, observed: 239

The question of copying is of some difficulty and the best test that appears to have been formulated is simply that something is a copy if it brings to mind the original. In other words, a copy is a copy if it looks like a copy...

Finally, there must also be a causal connection. It must be proved that the alleged infringer made unlawful use of the copyright protected work either directly or indirectly. ${ }^{240}$ The New Zealand Supreme Court in Henkel KgaA v Holdfast New Zealand Ltd, explained when this will be inferred by the courts: ${ }^{241}$

\footnotetext{
${ }^{236}$ Kingsbury, above n 173, at 64.

${ }^{237}$ Bonz Group, above n 178, at [226].

${ }^{238}$ Finch, above n 156, at 441.

${ }^{239}$ Thornton Hall Manufacturing Ltd v Shanton Apparel (No 2), above n 175, at 246.

${ }^{240}$ Finch, above n 156, at 443.

${ }^{241}$ Henkel KgaA v Holdfast New Zealand Ltd, above n 169, at [43].
} 
The closer the similarity between the two works the stronger the inference is likely to be that the one was copied from the other. If the alleged infringer has had access to, and therefore an opportunity to copy, the copyright work, and the similarity between the works supports an inference of copying, it may well be appropriate for the Court to conclude, on the balance of probabilities, that there was indeed copying. This, of course, is subject always to the evaluation of any evidence there may be that no copying actually took place.

Industrial designers often have access to the work of others, but copying will not be and should not be inferred where one designer's work merely influences the work of another. Company 'H' explained:

You can be inspired ... [but] that is different ... from someone who copies other people's work. It is much like an artist. You can be inspired by Piet Mondrian, or you can be inspired by Colin McCahon. That does not mean to say you make exactly what they did.

"It is the baton effect", company ' $G$ ' observed:

We create something, then someone finds a way to take that idea and make it into something else. Of course, that is the way we work and the way creativity has always worked, and you have to encourage that. It allows things to move forward and ideas to develop ...

The major limitation in the scope of copyright protection becomes evident when a design from New Zealand enters foreign markets. Although the Berne Convention provides for reciprocal copyright arrangements between member states, ${ }^{242}$ very few members recognise industrial designs as a subject of copyright protection. ${ }^{243}$ For this reason, New Zealand industrial design

\footnotetext{
${ }^{242}$ See Berne Convention, above n 108, at art 3.

${ }^{243}$ Ricketson and Suthersanen, above n 203, at 169 .
} 
owners who want to exploit their designs overseas should register them under the Designs Act 1953 ('Designs Act') in New Zealand and equivalent legislation for protection in the overseas markets. Moreover, it is vital that they do so before releasing the design in public, as public exposure of the design, even when copyright protected, removes the possibility of registration. $^{244}$

\subsubsection{Registered designs}

A significant incentive for design owners to register their design is the fact that they do not have to provide evidence of copying, should infringement occur. Such evidence is crucial when design owners rely solely on copyright; whereas a registered design is infringed by independent reproduction. In this regard, it offers similar protection to a patent. ${ }^{245}$ "That is the feature that I think a lot of people are not aware of", noted legal advisor 'L', "I think some people are thinking 'ok well I have copyright protection for free, why do I need to register the design?'”

Indeed, this view is prevalent, as evident in the following statements.

A design consultancy firm (company 'A') commented:

If you created a distinctive look and you get out there in the market, and somebody copies you, it is a pretty easy win in court - you can see it with your own eyes. You do not even need to spend any money ...

\footnotetext{
${ }^{244}$ Paul Sumpter Intellectual Property Law: Principles in Practice (2nd ed, CCH New Zealand Limited, Auckland, 2013) at 292. Exceptions in limited circumstances apply: see Designs Act 1953 (NZ), s 10. ${ }^{245}$ Sumpter, above n 244, at 283.
} 
A company that designs children's products (company 'J') stated "we haven't registered the designs ... largely as they are covered by copyright." Academic 'C' stated "design registration is usually pretty average. I do not think you will find many people using it." Although this is a common perception, it is ill-informed, because, in reality, as legal advisor ' $L$ ' pointed out: The process of proving that someone copied you can actually be quite difficult. Even in court, with the whole process of discovery, where all relevant information has to be disclosed, even then, it can still be difficult to connect the dots, to show copying has taken place.

Legal practitioner 'I' explained this further:

You cannot just rock up to court and say I have got copyright in this. There are two things that need to be done first. First of all, you need to establish to the satisfaction of the court that you have copyright in it. Then, the second more difficult test is that you have to prove that copying has taken place. So it is not just a case of they might look the same, you have to actually prove that they copied your one. That could be the difference between a twoday court fixture and a one-month court fixture. So ... if you ever had to enforce it ... getting a registered design ... could be a huge difference in outcome and cost. That is what they are for. They are there to make it easier to enforce these ... things.

Another advantage of registered designs over copyright, as a legal practitioner specialising in intellectual property (legal practitioner ' $M$ ') pointed out, is that it is "a searchable intellectual property right." For this reason, registered designs, legal practitioner 'I' explained:

... are much easier to transfer, to licence, and all those things. It is a public register, so there is clarity. If you want to know, if someone's got protection on something, you search the register. You cannot do that with copyright. You have to assume that copyright exists, but you do not know, whether it does or not. You do not know how old the product is. You do not know who might own it. 
As such, copyright is obviously much less useful for businesses. The other important factor that many businesses must consider is the legal protection of their designs overseas. Company 'H' commented:

The Copyright Act of New Zealand ... harks back to the Berne Convention, which is a reciprocal agreement. So any designs that are registered in Europe ... have automatic copyright protection here. So we do not have to register them ...

It is indeed true that New Zealand will provide copyright protection for foreign industrial designs, in accordance with the Berne Convention. ${ }^{246}$ However, as legal advisor ' $L$ ' pointed out "if you are wanting protection for the visual appearance of something outside New Zealand, you really have to rely on registered designs." This is because "in most countries, registered designs are the only way to get protection for three dimensional products", legal practitioner 'M' explained.

Thus, the fact that registration is recognised as evidence of design ownership in most countries is the other major benefit of registered designs. ${ }^{247}$ The register also acts as a legal indication of an industrial design's origin. This is beneficial because, even when the other country also recognises industrial designs as protectable subject matter under their copyright law, there still remains the matter of proving ownership of the original design. This can often be difficult, as explained above, to do domestically, let alone in a different country. Registration mitigates this particular problem.

\footnotetext{
${ }^{246}$ Berne Convention, above n 108, at art 2(7).

${ }^{247}$ Sumpter, above n 244, at 284.
} 


\subsubsection{Scope}

In order to qualify for registration under the Designs Act, a design must fall within the following definition: ${ }^{248}$

Features of shape, configuration, pattern, or ornament applied to an article by any industrial process or means, being features which in the finished article appeal to and are judged solely by the eye; but does not include a method or principle of construction or features of shape or configuration which are dictated solely by the function which the article to be made in that shape or configuration has to perform.

\subsubsection{1 "Appeal to and judged solely by the eye"}

There is no statutory guidance in New Zealand for determining whether something "appeals to" and can be "judged solely by the eye", rather, this factor seems to be decided on a case by case basis. Orit Afori explains that in the early stages of development of this area of common law in the United Kingdom, judges would have made the assessment based on what they found appealing to their own eyes. ${ }^{249}$ However, over time this changed, as is evident in Lord Morris' observation in the United Kingdom case of AMP Inc v Utilux Pty Ltd: ${ }^{250}$

The eye concerned will be the eye, not of the court, but of the person deciding whether or not to acquire the finished article possessing the feature in question. This does not mean that the "appeal" or the "attraction" must be in an aesthetic or an artistic sense though in some cases it may be. The features may be such that they gain the favour of or appeal to some while meeting with the disfavour of others. Beyond being merely visible

\footnotetext{
${ }^{248}$ Designs Act 1953 (NZ), s 2(1).

${ }^{249}$ Afori, above $\mathrm{n} 97$, at 1138 .

${ }^{250}$ AMP Inc v Utilux Pty Ltd [1972] RPC 103 (HL), at [112].
} 
the feature must have some individual characteristic. It must be calculated to attract the attention of the beholder.

In the above quote, Lord Morris illustrated that eye appeal is a subjective determination. However, Afori points out that even though courts have acknowledged subjectivity, it is unavoidable, as in the practical sense they are still required to make a subjective decision. ${ }^{251}$ Afori's observation can essentially be made with respect to virtually any common law test. The observation is in fact consistent with the pragmatic philosophy that underpins this study, namely that despite one's intention to be objective, the subjective nature of human experience makes complete objectivity impossible. ${ }^{252}$

The risk of subjective assessment could be eliminated by the removal of the words "appeal to" from the definition. ${ }^{253}$

\subsubsection{2 "Not a method or principle of construction"}

A method or principle of construction can also be understood as a solution to a technical problem or the result of an invention. This is the restricted domain of patent law. ${ }^{254}$

\footnotetext{
${ }^{251}$ Afori, above n 97, at 1136.

252 Richard Ormerod "The History and Ideas of Pragmatism" (2006) 57 J Oper Res Soc 892 at 892.

${ }^{253}$ This amendment to the legislation has been suggested in the past - see New Zealand Ministry of Commerce Competition Policy and Business Law Division Review of Industrial Property Rights Patents, Trade Marks and Designs (1990) at [22.4.4]; and Ministry of Commerce Business Policy Division Reform of the Designs Act 1953 and Other Issues Proposed Recommendations (1992) at 21.

${ }^{254}$ Kanwal Puri Industrial Design Law in Australia and New Zealand (Butterworths, Melbourne, 1986) at 38.
} 
Thus, to be registrable, the form of an industrial design can be, among other things, the result of decorative considerations, but what it must not be is the result of a method or principle of construction. ${ }^{255}$

\subsubsection{3 "Not features of shape or configuration which are dictated solely by function"}

Designs that comprise features of shape or configuration dictated solely by function are not registrable. ${ }^{256}$ Conversely, the Copyright Act has no such requirement. Therefore, solely functional industrial designs that meet the originality threshold are protected by copyright. An example of this was the toilet pan connector, which was found to be protected by copyright in PS Johnson \& Associates Ltd v Bucko Enterprises Ltd. ${ }^{257}$

TRIPS provides optional guidance in relation to functional designs, stating "members may provide that the protection shall not extend to designs dictated essentially by technical or functional considerations." 258

Although the TRIPS provision is not mandatory, it is noteworthy that it appears to be more restrictive than the relevant New Zealand provision. TRIPS recommends prohibiting designs that are dictated "essentially" by technical or functional considerations, ${ }^{259}$ whereas, in New Zealand, designs that are dictated "solely" by function are prohibited from registration. ${ }^{260}$ The European Union case of Doceram GmbH v CeramTec $G m b H,{ }^{261}$ sheds some light as to the

\footnotetext{
255 See Designs Act 1953 (NZ), s 2(1).

256 See Designs Act 1953 (NZ), s 2(1).

${ }^{257}$ PS Johnson \& Associates Ltd v Bucko Enterprises Ltd [1975] 1 NZLR 311 (SC).

${ }^{258}$ See TRIPS, above n 114, at art 25(1).

${ }^{259}$ Ibid.

${ }^{260}$ See Designs Act 1953 (NZ), s 2(1).

${ }^{261}$ Case C-395/16 DOCERAM GmbH v CeramTec GmbH [2018] ECLI 172.
} 
likely scope of protection the existing wording provides. Article 8(1) of Council Regulation No 6/2002 on Community Designs consists of similar wording to the definition provided in the Designs Act, namely: “...design shall not subsist in features of appearance of a product which are solely dictated by its technical function" (emphasis added). ${ }^{262}$ In considering the interpretation of Article 8(1), the Court of Justice of the European Union held that the existence of design alternatives, does not necessarily, equate to evidence of the design in question being dictated by considerations other than technical function. ${ }^{263}$ The creator's choice of design must have been influenced by non-functional considerations, in particular those related to its visual appearance. $^{264}$

\subsubsection{New or original requirement}

Designs that satisfy the definition of "design" in the Designs Act may be registered, provided that they are "new or original". 265

Although the Designs Act predates TRIPS, it nevertheless uses the same words in its requirement for registration, namely "new or original". ${ }^{266}$ The words used in New Zealand were adopted from the United Kingdom, where "new and original" was used as early as the very first design statute, which was passed in $1787 .{ }^{267}$ Designs that were applied industrially became registrable under the Utility Designs Act 1843, at which point the conjoining word "and" in the requirement for registration was replaced with "or". ${ }^{268}$

\footnotetext{
${ }^{262}$ Regulation 6/2002 on Community Designs [2002] OJL3/1.

${ }^{263}$ Case C-395/16 Doceram GmbH v CeramTec GmbH, above n 261, at [22].

${ }^{264}$ Ibid, at [31].

${ }^{265}$ See Designs Act 1953 (NZ), s 5.

${ }^{266}$ See Designs Act 1953 (NZ), s 5.

${ }^{267}$ Laddie, Prescott and Vitoria, above n 59, at 1045.

268 Ibid, at 1049.
} 
The requirement, as noted above, is potentially ambiguous. ${ }^{269}$ However, it is clear that the threshold for registration in New Zealand requires more than just the level of originality that is required for copyright. The Designs Act states: 270

Subject to the provisions of this Act, a design shall not be registered thereunder unless it is new or original and in particular shall not be so registered in respect of any article if it is the same as a design which before the date of the application for registration has been registered or published in New Zealand in respect of the same or any other article or differs from such a design only in immaterial details or in features which are variants commonly used in the trade.

New Zealand courts have determined that the requirement is substantially higher than “independent creation". In UPL Group Limited v Dux Engineers Limited ${ }^{271}$ Somers J stated "the test is whether the article alleged to be an infringement has substantially the same appearance as the registered design." 272

In Sutton v Bay Masonry Ltd, ${ }^{273}$ the High Court (due to a lack of New Zealand law in this area) cited the following observation from Conrol Pty Ltd $v$ Meco McCallum Pty Ltd, ${ }^{274}$ as to how to discern what is "new or original":275

Determining whether a design is new or original must involve some comparison between the design and the prior art...It is not possible to define with any degree of precision how much a design must differ from prior art before it will be regarded as new or original. The question must be answered according to the facts of each case.

\footnotetext{
${ }^{269}$ See the discussion above in Section 3.2.3: TRIPS Agreement.

${ }^{270}$ Designs Act 1953 (NZ), s 5(2).

${ }^{271}$ UPL Group Limited v Dux Engineers Limited, above n 92.

272 Ibid, at [139].

273 Sutton v Bay Masonry Limited unreported, High Court, Tauranga CIV 2003-470-260, 28 May 2004.

${ }^{274}$ Conrol Pty Ltd v Meco McCallum Pty Ltd, (1996) 34 IPR 157 (FCA).

275 Sutton v Bay Masonry Limited, above n 273, at [17].
} 
The statement of novelty requirement, ${ }^{276}$ provides the design owner with the means to specify how their design is novel in light of the prior art. The statement must set out any features of shape, configuration, pattern or ornamentation that are novel (i.e. new or original) for which protection is sought. ${ }^{277}$ The statement of novelty can be with respect to the design as a whole or limited to the particular part of the design which is novel. ${ }^{278}$

\subsubsection{Infringement}

A design is not novel if it is substantially similar to an earlier design. However, one only infringes a registered design, if their allegedly replicated, or substantially similar design is applied to an article in respect of which an earlier design is registered. ${ }^{279}$

A comparative exercise (taking into account prior art as well as the statement of novelty) between the design complained about and the registered design is required to determine whether infringement has occurred. ${ }^{280}$ What constitutes substantial difference will be determined in light of the prior art. The Court in UPL Group Ltd $v$ Dux Engineers Ltd explained: ${ }^{281}$

If there is substantial novelty or originality small variations in the article alleged to infringe will be unlikely to save the defendant. On the other hand if the features of novelty or originality are but little removed from prior art small differences may avoid infringement.

\footnotetext{
276 See Designs Regulations 1954 (NZ), reg 23.

277 “Apply for a Design” New Zealand Intellectual Property Office <www.iponz.govt.nz>.

${ }^{278}$ Finch, above n 156, at 565.

${ }^{279}$ Ibid, at 577.

${ }^{280}$ Ibid at 578 .

${ }^{281}$ UPL Group Limited v Dux Engineers Limited, above n 92, at 139.
} 
Courts may also apply an imperfect recollection test which is determined from the perspective of a consumer who viewed the respective designs at different times as opposed to side by side. $^{282}$

If the infringer can prove that they were not aware and had no reasonable grounds for supposing that the design was registered in New Zealand, they will not be liable for damages or an account of profits. An injunction however, may still be granted. ${ }^{283}$

\subsubsection{Examination}

Before a design is registered it is subject to an examination which is usually conducted within 15 working days of an application being made. ${ }^{284}$ After the examination, the applicant is issued with either a certificate of registration, ${ }^{285}$ or an examination report setting out any objections to registration. ${ }^{286}$ The certificate of registration identifies the date of registration, namely the date the application was filed, as well as the date that the certificate was issued. ${ }^{287}$ In the event that there are objections, the applicant has one month to file for a hearing, or the application is deemed to have been withdrawn. ${ }^{288}$

Although examination in New Zealand is not required to be substantive, ${ }^{289}$ in the opinion of several legal practitioners/advisors, it tends to be quite substantive in practice. "We do our best in the examination. It's not just a cursory examination. There is a considerable amount of

\footnotetext{
${ }^{282}$ Finch, above n 156, at 578.

${ }^{283}$ See Designs Act 1953 (NZ), s 13.

284 "Examination Process" New Zealand Intellectual Property Office <www.iponz.govt.nz〉.

285 Ibid

${ }^{286}$ See Designs Regulations 1954 (NZ), reg 36.

${ }^{287}$ Finch, above n 156, at 572.

${ }^{288}$ See Designs Regulations 1954 (NZ), reg 36.

${ }^{289}$ See Designs Act 1953 (NZ), s 7(2).
} 
searching", a legal advisor specialising in intellectual property (legal advisor 'N') pointed out. "IPONZ [Intellectual Property Office of New Zealand] will do a search of the existing designs on the register. Also, they can choose to do, for example, an internet search on top of that", legal advisor 'L' explained.

Another legal practitioner specialising in intellectual property (legal practitioner ' $\mathrm{O}$ ') was also of the opinion that "New Zealand has a pretty good ... examination system .... If you contrast it to Australia ... our examination process is pretty fair already", they pointed out, before providing the following example:

I could file a design ... in Australia ... tomorrow for the iPhone 6 and provided I have done all the formalities correctly, they will register it. There is no examination. Examination happens post registration, and you have to request it. Whereas, if I did the same thing in New Zealand, they would immediately say "that is an iPhone 6" and would probably also throw up a Samsung Galaxy S6 as well, and ask "what are the new original features of this, over that?"

Although the examination process in Australia may be significantly less thorough, it is still accurate to describe the current examination process in New Zealand as less than thorough. This is because the examination that the legal practitioners/advisors describe above, is nevertheless, limited to a search on the register (and only the New Zealand register), which is itself limited, ${ }^{290}$ as well as an internet search. It is therefore, by no means thorough, as a legal practitioner specialising in intellectual property (legal practitioner 'I') pointed out:

They do not do a comprehensive search by any means. Basically they just make sure there is nothing there that is obviously going to knock it out. Then they grant it.

\footnotetext{
${ }^{290}$ Limitations of New Zealand's existing design register are discussed below. Suggestions and recommendations for improving the register are provided in Section 6.2.4: Adequacy of New Zealand design register.
} 
Afori argues that a non-substantive examination is better suited to industrial designs than the more substantive examination that is required for patents. ${ }^{291}$ Although Afori's observation was drawn out of his comparison of the design systems of the United Kingdom and the European Union with that of the United States, it may also be relevant, by analogy, to New Zealand.

The first reason identified by Afori for why non-substantive examination is better suited for industrial designs is their tendency to be "trend-sensitive". ${ }^{292}$ Businesses often need to get their designs onto the market quickly, before the appeal is lost.

The second reason is that substantive examination is costly, and would push registration costs up. For many businesses such high costs would simply outweigh the risk. ${ }^{293}$ Indeed, as Daniel Gervais notes, in practice most industrial designs prove not to be commercially exploitable once they enter the market. ${ }^{294}$ This is because developing a design that successfully appeals to the target market is a very difficult process. In fact, most design ideas end up going nowhere, as a multinational company (company ' $\mathrm{B}$ ') pointed out:

We get a lot of people coming to us every week, saying "I have this great idea". The reality is ... any idea to develop takes a lot of effort ... and ... we have probably thought about most of the ideas and either discarded them as crazy, or not good timing.

A successful industrial design must reflect a very precise balance in relation to a series of aesthetic principles, as well as accommodate several other considerations, including ergonomics and product function. ${ }^{295}$

\footnotetext{
${ }^{291}$ Afori, above n 97, at 1135 .

292 Ibid, at 1148.

${ }^{293}$ Ibid, at 1150 .

${ }^{294}$ Gervais, above n 121, at 328.

${ }^{295}$ See the discussion in Section 2.2: The Role of the Industrial Designer.
} 
So, would a more substantive examination process prove more beneficial for successful industrial designs? This question was recently raised in Singapore in a review of their registered design system. ${ }^{296}$ The major benefit identified was greater certainty in regard to the validity of registration. Without a substantive examination, there is a much greater burden on the design owner to prove that their registration is valid, should an infringement action based on invalid registration arise. ${ }^{297}$ Despite the clear benefit, however, the Ministry of Law and the Intellectual Property Office of Singapore did not recommend implementing a substantive examination process. ${ }^{298}$ Aside from the two reasons identified by Afori, noted above, the Ministry of Law and the Intellectual Property Office of Singapore also identified the difficulty of navigating the design register as an additional reason, noting that the register was far less comprehensive than their patent register. ${ }^{299}$

In New Zealand the design register is reasonably straightforward. However, the search options are quite limited. Most notable is the lack of categorisation, which makes more general searches difficult and time consuming. At present the searches are effectively limited to keywords. Relying on such searches may be dangerous because, as a multinational company (company 'F') pointed out, "the searching ... is quite fragmented" and thus the non-specialist user is "highly likely to miss a number of things."

The fact that a legal specialist is required just to conduct a comprehensive search of the register puts into question the supposed low cost of the current registration system. ${ }^{300}$

\footnotetext{
296 Ministry of Law and the Intellectual Property Office of Singapore Final Report Review of Singapore's Registered Designs Regime (2016).

${ }^{297}$ Ibid, at [3.1.3].

298 Ibid, at [3.1.8].

${ }^{299}$ Ibid, at [3.1.4].

${ }^{300}$ Suggestions and recommendations for improving the design register are provided in Section 6.2.4: Adequacy of New Zealand design register.
} 


\subsubsection{Term of protection}

The mandatory minimum period of protection prescribed by TRIPS is 10 years. ${ }^{301}$ In New Zealand, a design is provided with five years protection upon initial registration. A design owner may choose not to reapply for protection after this initial period, in which case the design will only have received a total of five years' protection. This may appear to be below the minimum term prescribed by TRIPS. However, in New Zealand, 15 years protection is made "available" to design owners. A maximum of 15 years is "available" to them, subject only to reapplication and payment of fees. ${ }^{302}$

Company ' $G$ ' expressed their frustration with this renewal requirement:

If you do not renew it after five years, then that is it, you have lost it. Why do you have to do that? What is the point of renewing it? It is a waste of time and resources.

Conversely, it is arguable that the option of reapplication after five years is a useful feature. Businesses may discover that they no longer require protection after five years, for whatever reason. This way they do not need to pay the additional fee for longer protection.

\subsubsection{Overlapping rights}

New Zealand provides a broad scope of protection for industrial design. It is broad in the sense that design owners enjoy the possibility of acquiring protection for industrial designs via the multiple legal mechanisms, which were discussed above.

\footnotetext{
${ }^{301}$ See TRIPS, above n 114, at art 26(3).

302 Designs Act 1953 (NZ), s 12(2).
} 
An industrial design acquires automatic copyright protection as an artistic work, provided that it meets the originality threshold. ${ }^{303}$ Some of the more innovative designs may even be eligible for patent protection. ${ }^{304}$ As patents protect inventions and copyright protects creative expressions, the intellectual property rights provided under these two distinct protection mechanisms do not appear, at least prima facie, to overlap. ${ }^{305}$ It is however, worth noting that copyright protection can extend to artistic works which are purely functional. ${ }^{306}$ Function however, as the underlying method or principle of construction, is arguably a more appropriate candidate for patent protection. ${ }^{307}$ Ken Moon explains that this overlap was not envisioned by the Copyright Committee in their 1959 report, ${ }^{308}$ in which they recommended adopting the broad definition of "artistic work". ${ }^{309}$ On the one hand, this unintended consequence is mitigated, because the copyright term has been, as noted above, reduced, to align it with patent duration. ${ }^{310}$ On the other hand, it seems that purely functional designs which do not meet the much higher threshold for patent protection, ${ }^{311}$ may essentially be receiving a very high level of protection via copyright in New Zealand.

Although many copyright protected industrial designs will also qualify for registered design protection, there is no overlap between these two mechanisms with respect to solely functional designs. Such designs are expressly excluded from the ambit of the registered design system. ${ }^{312}$

\footnotetext{
${ }^{303}$ See Copyright Act 1994 (NZ), s 14.

${ }^{304}$ For patentability requirement -see Patents Act 2013 (NZ), s 14.

${ }^{305}$ Ken Moon "A Functional View of Copyright, Designs and Patents" (1975) 8 VUWLR 300 at 310.

${ }^{306}$ Ibid, at 315 .

${ }^{307}$ Ibid, at 316.

${ }^{308}$ See Copyright Committee Report Presented to the House of Representatives (NZ, 1959).

${ }^{309}$ Moon, above n 305, at 315.

${ }^{310}$ Copyright term for "artistic work applied industrially" was reduced to 16 years via the Copyright Amendment Act 1985 (NZ), s 5. At the time this was the same duration as a patent - see Patents, Designs, and Trade-marks Act 1921 (NZ), s 19.

${ }^{311}$ See Patents Act 2013 (NZ), s 14.

312 See Designs Act 1953 (NZ), s 2(1).
} 
It is also possible for an industrial design to be registered as a trade mark. This can occur where an industrial design is itself recognised by consumers as being a distinctive feature of a particular trader. ${ }^{313}$ As noted above, very few designs acquire such distinctiveness during a product's lifecycle. ${ }^{314}$ The Fair Trading Act 1986 and the tort action of passing off are further legal mechanisms which can be utilised. As a well-established reputation in the market must be shown however, few industrial design owners will have recourse to these mechanisms in practice. ${ }^{315}$

Although there are multiple potential legal mechanisms available for protecting industrial designs in New Zealand, the rights provided to design owners, must be balanced with the rights of competitors as well as the greater public, in the interests of competition.

\subsubsection{Competition law}

Competition is an essential ingredient of capitalism. Producing a product at a lower cost than the original manufacturer and underselling them is considered to be a fundamental aspect of competition. With the exception of the tort of passing off, the common law of the courts generally does not interfere with such practice. ${ }^{316}$

There is, however, legislation in place to ensure that those who develop the original product design have the opportunity to recoup their investment of time, money, etc. The rationale for

\footnotetext{
${ }^{313}$ See Fredco Trading Ltd v Miller, above n 142, at 762.

${ }^{314}$ See Section 3.3.1: Trade marks and patents.

${ }^{315}$ See Section 3.3.2: Passing off and the Fair Trading Act 1986.

316 Paula Baron "Where art meets science beauty meets utility: the strange world of industrial design protection" (1999) 18 Tasm U L Rev 194 at 196.
} 
providing a period of exclusive rights to original industrial design owners has traditionally been to encourage manufacturing. ${ }^{317}$

There is thus an inherent tension between these two fundamental and yet competing ideologies. ${ }^{318}$ The policy that underlies the correlation between the two ideologies stresses that any impact on competition resulting from industrial design protection must be justified in light of the public benefit. ${ }^{319}$

In New Zealand, intellectual property rights provided under the law, including those provided for industrial design owners under the copyright and registered design systems, are balanced against competition rights, in facilitation of a fair market economy. The balance struck in New Zealand is indicated in the Commerce Act 1986 ('Commerce Act'): ${ }^{320}$

A person that has a substantial degree of power in a market must not take advantage of that power for the purpose of:

(a) restricting the entry of a person into that or any other market; or

(b) preventing or deterring a person from engaging in competitive conduct in that or any other market; or

(c) eliminating a person from that or any other market.

The balance of interests is however, tipped in favour of the intellectual property owner. The Commerce Act provides: $:^{321}$

\footnotetext{
${ }^{317}$ Ibid, at 197.

318 Ibid.

${ }^{319}$ Matt Sumpter "IP and Competition Law: Friends or Foes?” (2010) 6(2) NZIPJ 702 at 702.

${ }^{320}$ Commerce Act 1986 (NZ), s 36(2).

${ }^{321}$ Commerce Act 1986 (NZ), s 36(3). Note: although it is permissible to enter into a contract containing a provision authorising an act that would otherwise be prohibited because of the existence of an intellectual property right, such a provision cannot be utilised to facilitate an abuse of power - see Commerce Act 1986 (NZ), s 45.
} 
a person does not take advantage of a substantial degree of power in a market by reason only that the person seeks to enforce a statutory intellectual property right ...

This exception has never been tested by the courts in New Zealand. Therefore, it is unclear under what circumstances one would be considered to have abused their intellectual property rights. $^{322}$

John Cross and Peter Yu discuss what may constitute an abuse of intellectual property rights. Their observations are made in light of the competition law in Canada and the United States. ${ }^{323}$ Canada provides a similar exception with respect to intellectual property rights, in its competition law, as New Zealand. ${ }^{324}$ The United States does not have a default exception of this nature, but rather the anti-competitive and pro-competitive effects of the exercise of intellectual property rights are weighed up on a case by case basis. ${ }^{325}$ Cross and Yu note that despite the differences in approach, many of the same situations will be determined as having involved abuse of intellectual property rights. ${ }^{326}$ An obvious example of such a circumstance is where several companies with copyrighted products collude by pooling their assets, and in so doing, essentially divide the market amongst themselves, ${ }^{327}$ barricading new entrants.

The licencing of intellectual property is perhaps the scenario where abuse of intellectual property rights is most likely to occur. Licencing out one's intellectual property at excessive prices however, is highly unlikely to be considered an abuse of one's rights. This is because

\footnotetext{
322 Ministry of Business, Innovation \& Employment Discussion Paper: Review of Section 36 of the Commerce Act and other matters (2019) at [221]. It is noteworthy that a repeal of Section 36 has been recommended in the discussion paper because, among other reason, its current formulation has the potential for being interpreted inconsistently with the purpose of the statute.

${ }^{323}$ See John Cross and Peter Yu "Competition Law and Copyright Misuse" (2008) 56 Drake L Rev 427.

${ }^{324}$ See Competition Act RSC C 1985 c C-34 (CA), s 79(5).

${ }^{325}$ Cross and $\mathrm{Yu}$, above $\mathrm{n} 323$, at 443.

${ }^{326}$ Ibid.

${ }^{327} \mathrm{Ibid}$, at 436 .
} 
such behaviour is the expected consequence of exclusive rights. ${ }^{328}$ The only exception, is perhaps where the intellectual property rights holder has an overly dominant position in the market. ${ }^{329}$ One is very unlikely however to acquire such a dominant position by means of only having copyright in a particular work. ${ }^{330}$ As copyright provides exclusive rights in expressions rather than ideas, substitute products are usually going to be readily available to consumers. ${ }^{331}$ Although design registration provides a broader monopoly in the sense that one need not prove copying actually took place, ${ }^{332}$ exclusive rights are nevertheless limited to the registered design applied to a particular article. ${ }^{333}$ Hence, one is also unlikely to acquire a dominant position in the market by means only of the exclusive rights acquired through design registration.

Behaviour that is much more likely to be considered an abuse of one's exclusive rights is where the intellectual property owner forces the licensee to agree to non-price related concessions in the licence contract. ${ }^{334}$ For example, the creator of a copyright protected work may set terms of licence which far exceed the bargain made between society and the creator under the copyright regime. ${ }^{335}$ Similarly, a registered design owner may seek to obtain concessions from the licensee which far exceed those rights that are granted by virtue of design registration.

There is also the question of whether refusing to licence at all could constitute an abuse of one's intellectual property rights. Again, this is not an issue that has come before New

\footnotetext{
${ }^{328}$ Ibid, at 443.

${ }^{329}$ Ibid.

${ }^{330}$ Ibid, at 444

${ }^{331}$ Stan Liebowitz “A Critique of Copyright Criticisms” (2015) 22 Geo Mason L Rev 943 at 948.

${ }^{332}$ Sumpter, above 244, at 283.

${ }^{333}$ See Designs Act 1953 (NZ), s 2(1).

${ }^{334}$ Cross and $\mathrm{Yu}$, above $\mathrm{n} 323$, at 444.

${ }^{335}$ Ibid.
} 
Zealand Courts, but based off of Cross and Yu's observations with respect to the competition law in the United States and Canada, it appears that refusal to licence will rarely amount to an abuse of one's intellectual property rights. ${ }^{336}$ One is not ordinarily under any obligation to assist competitors. The obvious exception, is where the intellectual property in question is an essential ingredient for further innovation in the industry. ${ }^{337}$ This will usually be the case where the intellectual property in question has become standard in the industry and hence where a substitute is essentially implausible. ${ }^{338}$ This is a very unlikely scenario in the copyright or registered design context by nature of what is actually protected, such as a particular expression or product appearance. However a refusal to licence will constitute abuse where the intellectual property in question is a crucial piece of patented technology, commonly referred to a standard essential patent. ${ }^{339}$

Another scenario where a refusal to licence is likely to constitute an abuse of intellectual property rights, is where the refusal enables the intellectual property owner to attain a dominant position in a secondary market. ${ }^{340}$

\subsubsection{Competition and the "spare parts exception"}

The spare parts market, has been recognised in the United Kingdom, as a secondary market which could be dominated by industrial design owners by virtue of their exclusive rights in the primary market. $^{341}$

\footnotetext{
${ }^{336}$ Ibid, at 448 .

${ }^{337}$ Ibid, at 449.

${ }^{338}$ Ibid.

${ }^{339}$ Guangjie Li Revisiting China's Competition Law and its Interaction with Intellectual Property Rights (Nomos Verlag, Germany, 2018) at 59.

${ }^{340}$ Cross and $\mathrm{Yu}$, above $\mathrm{n} 323$, at 453.

${ }^{341}$ Wayne Condon and Richard Hoad "New Design Laws" (2004) 42 J L Soc'y NSW 52 at 54.
} 
The United Kingdom House of Lords decision in British Leyland Motor Corp Ltd v Armstrong Patents Co Ltd ('British Leyland'), ${ }^{342}$ was the first to consider the implications of allowing a "spare parts exception".

Armstrong manufactured replacement exhaust pipes for British Leyland's vehicles without a licence and so British Leyland's sought an injunction. ${ }^{343}$

Both the High Court and Court of Appeal had found an infringement of copyright had occurred when Armstrong copied British Leyland's exhaust systems. On appeal, the House of Lords upheld this finding, but nonetheless allowed the appeal, based on the reasoning that a free market in spare parts was necessary to provide for the car owner's inherent right to repair their vehicle at an affordable price. ${ }^{344}$

In so doing, the House of Lords established the "spare parts exception", which was based not on any principle of law, but rather public policy. ${ }^{345}$ The exception protects the consumer from excessive prices, resulting from the original manufacturer's exclusive intellectual property rights extending into the replacement parts market. ${ }^{346}$ Thus by way of this exception, the public interest in having affordable replacement parts, overrides the manufacturer's right to exclusive exploitation in the secondary market. ${ }^{347}$ The exception is however, limited to replacement parts for the purposes of repair. ${ }^{348}$

\footnotetext{
${ }^{342}$ British Leyland Motor Corp Ltd v Armstrong Patents Co Ltd [1986] 1 All ER 850 (HL).

${ }^{343}$ Ibid, at 864.

${ }^{344}$ Ibid, at 861 .

${ }^{345}$ See Ibid, at 884 .

${ }^{346}$ Jason Rawkins "Copyright - designs - British Leyland spare parts defence (1997) 19 EIPR 674 at 676.

${ }^{347}$ Andrew Tettenborn "Copyright and Spare Parts: Judicial Legislation in a Good Cause" (1986) 45 Cambridge LJ 216 at 217.

${ }^{348}$ See British Leyland Motor Corp Ltd v Armstrong Patents Co Ltd, above n 342, at 861. Note, the Privy Council held that replacement printer cartridges did not come within the scope of the exception - See Canon Kabushiki Kaisha v Green Cartridge Co Ltd [1997] 2 HKC 1 (HK).
} 
In Mono Pumps (New Zealand) Ltd v Karinya Industries Ltd, ${ }^{349}$ the New Zealand High Court did not follow the United Kingdom decision in British Leyland. The High Court was of the opinion that any perceived gaps in the legislation should be addressed by Parliament. ${ }^{350}$

It is arguable that the balance between intellectual property and competition law would be better struck if New Zealand were to provide a "spare parts exception". Further discussion on the potential usefulness of a "spare parts exception" is provided in Chapter 6, which provides suggestions and recommendations for New Zealand policy and its law makers as to how to appropriately protect industrial designs in light of foreseeable advances in technology. The potential impact of such technology on intellectual property protection is discussed in Chapter 5. The following Chapter provides an overview of the legal, cultural and economic context in China. Drawing on the discussion in Chapter 4, Chapter 7 provides suggestions and recommendations for New Zealand design owners manufacturing their designs in China.

\footnotetext{
${ }^{349}$ Mono Pumps (New Zealand) Limited \& Anor v Karinya Industries Limited \& Ors (1986) 1 NZBLC 102, at [575].

${ }^{350}$ Ibid, at [582].
} 


\section{Legal Protection for Industrial Designs in China}

As many New Zealand industrial design owners manufacture their industrial design in China, it is important that they are aware of how to appropriately protect their designs there. This Chapter provides an outline of the intellectual property protections that can be used to protect industrial designs in China. The discussion of each type of protection begins with a brief outline of its historic development and is followed by more specific analysis of key legal elements. Following the discussion of the legal protections and their respective elements is a section on the competition law in China. This section provides a basic outline as to the extent one can expect competition law to affect intellectual property rights in China.

Although the letter of the law is continually improving, enforcement, at least in some parts of China, remains unsatisfactory. This Chapter provides an overview of the cultural and economic context that underpins the Chinese intellectual property system and its enforcement. In addition to the overview of past and existing enforcement measures being implemented in China, expectations and plans for intellectual property rights enforcement in the foreseeable future are also discussed.

Building on the discussion of intellectual property protections outlined in this Chapter and taking into consideration the issues relating to enforcement, Chapter 7 provides suggestions and recommendations as to both legal and non-legal strategies for protecting industrial designs in China. 


\subsection{Copyright Law}

The first formal copyright law was the Copyright Law of the Great Qing Dynasty $1910 .{ }^{1}$ The Qing Dynasty was overthrown in 1912, but the subsequent Copyright Law in 1915 had only minor alterations, and the Copyright Law of 1928 was likewise only slightly revised. This law remained in effect until the Communist Regime took control after the Second World War in 1949. ${ }^{2}$ The Communist government implemented a series of laws and regulations that still purported to protect, in certain instances, rights synonymous with copyright. ${ }^{3}$

From 1966 began a period lasting more than a decade during which China was effectively devoid of copyright protection. ${ }^{4}$ This was the Cultural Revolution, a period in Chinese history during which societal mistrust for formal laws reached its pinnacle. Almost all formal law was essentially dismantled during this period. ${ }^{5}$ Underpinned by Confucian philosophy, the Cultural Revolution transformed the country into a socially governed state, where acceptable conduct was almost entirely based on social norms. ${ }^{6}$ Those who defended the formal legal system were, of course, primarily individuals from within the system, such as lawyers and judges, but there were also others, including scientists and academics. ${ }^{7}$ Such individuals were sent away to rural

\footnotetext{
${ }^{1}$ Gregory Kolton “Copyright Law and the People's Courts in the People's Republic of China: A Review and Critique of China's Intellectual Property Courts" (1996) 17(1) U Pa J Int'l Econ L 415 at 415.

${ }^{2}$ Raymond Gabriel "The Patent Revolution: Proposed Reforms in Chinese Intellectual Property Law, Policy and Practice Are the Latest Step to Bolster Patent Protection in China" (2008) 9 APLPJ 323 at 327.

${ }^{3}$ Kolton, above n 1, at 416.

${ }^{4}$ Ibid.

5 Geoffrey Willard “An Examination of China's Emerging Intellectual Property Regime: Historical Underpinnings, the Current System and Prospects for the Future" (1996) 6(2) Ind Int'l \& Comp L Rev 411 at 418. ${ }^{6}$ Pat Chew "The Rule of Law: China's Scepticism and the Rule of People" (2005) 20 Ohio St J on Disp Resol 43 at 49.

7 John Allison and Lianlian Lin "The Evolution of Chinese Attitudes toward Property Rights in Invention and Discovery” (1999) 20 U Pa J Int'l Econ L 735 at 751.
} 
areas to be re-educated in revolutionary values. ${ }^{8}$ Some individuals were even arrested and jailed. ${ }^{9}$

The Cultural Revolution period came to an end when Chairman Mao Zedong died. During his tenure, China had largely closed itself off to the rest of the world. However, the new government led by Deng Xiaoping wanted to modernise the country for the purposes of engaging in world trade. ${ }^{10}$ To do this, a formal legal system needed to be re-established. ${ }^{11}$

Policies calling for the re-establishment of an intellectual property rights protection system, including copyright emerged in the late $1970 \mathrm{~s},{ }^{12}$ largely driven by pressure from the United States. ${ }^{13}$ The United States saw a lot of potential in China's large market but needed assurance that its intellectual property would be protected. China obliged, as they were interested in attracting foreign investment in their economy, particularly from wealthy countries such as the United States. ${ }^{14}$ After over 20 revisions and drafts over the next decade, the Copyright Law of the People's Republic of China ("Copyright Law") finally came into force in 1991. ${ }^{15}$

Even with this law in place, however, the United States continued to be dissatisfied with the protection provided and relied on coercive tactics to seek improvements, namely threats of economic sanctions and trade wars. Coercive tactics culminated in their opposition to China

\footnotetext{
${ }^{8}$ Willard, above $\mathrm{n} 5$, at 418 .

${ }^{9}$ Gabriel, above n 2, at 328 .

${ }^{10}$ Ibid.

${ }^{11}$ Ibid, at 329.

${ }^{12}$ Kolton, above n 1, at 416.

13 Peter Yu "Intellectual Property, Economic Development, and the China Puzzle" in Daniel Gervais (ed) Intellectual Property, Trade and Development: Strategies to Optimise Economic Development in a TRIPS Plus Era (Oxford University Press, New York, 2007) 173 at 213.

${ }^{14}$ Michael Berrell and Jeff Wrathall "Changing Attitudes to Intellectual Property Rights in China: The Nexus between Chinese Culture and the Rule of Law" (paper presented to the Conference of the Association for Chinese Economics Studies, Melbourne, 2003) at 7.

${ }^{15}$ Kolton, above n 1, at 417.
} 
joining the World Trade Organisation (WTO). ${ }^{16}$ The effort China was making to improve its intellectual property system was, however, finally recognised by the WTO when China became a member in $2001 .{ }^{17}$

Since then, the copyright system in China has been progressively improving and consequently gaining popularity with copyright holders. Although, in accordance with the Berne Convention for the Protection of Literary and Artistic Works 1886 ("Berne Convention"), registration is not mandatory, ${ }^{18}$ the option is provided in China and is highly utilised. In 2016, the State Intellectual Property Office of the People's Republic of China (SIPO) reported a total of $2,007,600$ registrations for the year, which was a $22.33 \%$ increase on the previous year. ${ }^{19}$

Despite growing popularity, the current copyright legislation in China still has some significant flaws. One of the primary reasons why it has taken China so long, in a sense, to Westernise its Copyright Law, has to do with Chinese wariness of this mechanism. ${ }^{20}$ Although China was willing to modernise its intellectual property system for the purposes of increasing trade relations with the Western world, it was only willing to do so to the extent that the changes were still acceptable under "the Chinese way of doing things" (quoquing 国情). ${ }^{21}$ Of all the different intellectual property mechanisms, copyright law was the last to be introduced due to it being perceived as being associated with information control, and propaganda. ${ }^{22}$

\footnotetext{
${ }^{16} \mathrm{Yu}$, above $\mathrm{n} 13$, at 186.

${ }^{17}$ Ibid, at 196.

${ }^{18}$ See The Berne Convention for the Protection of Literary and Artistic Works (9 November 1886, as revised at Paris 1986, Berlin 1908, Rome 1928, Brussels 1948, Stockholm 1967, Paris 1971, amended 28 September 1979), art 5(2).

19 State Intellectual Property Office of the People's Republic of China (SIPO) Intellectual Property Rights Protection in China (2016) at 6.

${ }^{20} \mathrm{Yu}$, above $\mathrm{n} 13$, at 212.

${ }^{21}$ Berrell and Wrathall, above n 14, at 11.

${ }^{22} \mathrm{Yu}$, above $\mathrm{n} 13$, at 212.
} 


\subsubsection{Applicable categories}

To date, the Copyright Law does not expressly list "works of applied art" as a copyrightprotected work. ${ }^{23}$ Protection by inference for foreign works is, however, ensured under the Berne Convention, which reads: ${ }^{24}$

Works protected in the country of origin solely as designs and models shall be entitled in another country of the Union only to such special protection as is granted in that country to designs and models; however, if no such special protection is granted in that country, such works shall be protected as artistic works.

\subsubsection{Scope}

In China, copyright only protects the artistic aspect of the applied art work, with the functional aspect being only protectable via patent. ${ }^{25}$ Thus, in order to be protected as a "work of applied art" in China, the work's artistic aspect must be at least conceptually separable from its functional aspect. ${ }^{26}$

The exclusive rights that are provided for copyright-protected works are listed in Article 10 of the Copyright Law. ${ }^{27}$ In the event that the work is copied without the owner's consent, the owner of the protected work must show that the allegedly infringing work is either the same or substantially similar to their own. ${ }^{28}$

\footnotetext{
${ }^{23}$ Zhou Yunchuan "Protection of Copyright in Applied Art" (2013) 4 CPT 71 at 72.

${ }^{24}$ Berne Convention, above n 18, at art 2(7).

${ }^{25}$ See Hu Sansan v Qiu Haisuo and National Art Museum of China Beijing Higher People's Court No 18 (2001). cf New Zealand copyright law which also protects the functional aspects of the work - See discussion in Section 3.3.3.2: Applicable categories.

${ }^{26}$ Ibid.

27 The Copyright Law of the People's Republic of China 1991 (as amended up to the decision of 26 February 2010, effective as of 1 April 2010), art 10.

${ }^{28}$ See OKBaby Ltd v Cixi Jiabao Child Product Ltd Beijing Intermediate People's Court No 12293 (2008).
} 


\subsubsection{Requirements}

The threshold for copyright protection is generally low. For most works to attain copyright protection in China, it is usually sufficient that the work originates from the author, irrespective of the extent of creative merit, be it artistic or otherwise. ${ }^{29}$

However, the judicial consensus in China in relation to typical industrial designs is that they do not come within the ambit of "works of applied art". The general reasoning for this is that the appropriate mechanism for protecting typical industrial products is a design patent. Therefore, the threshold for "works of applied art" is significantly higher than for most other copyright works. ${ }^{30}$

The majority of courts that have decided on the issue in China have indicated that in addition to being independently created, "works of applied art" must also contain a substantial degree of artistic merit. ${ }^{31}$ In Ai Lu Mu International Inc v Huizhou Xin Li Da Electronic Tools Ltd, ${ }^{32}$ the court held that in order to be protected as a 'work of applied art', the work had to reach a high enough degree of creativity. It was held that the plastic band cutter, which was the work in question, was lacking sufficient artistic element. Therefore, it was not protected. In OKBaby Ltd v Cixi Jiabao Child Product Ltd, ${ }^{33}$ the court held that to be protected as a work of applied art, the work had to be aesthetically significant. It was held that a child's potty, which was designed in the shape of an animal, had sufficient aesthetic value to be protected. In Inter IKEA

\footnotetext{
${ }^{29}$ Yunchuan, above n 23, at 75.

${ }^{30}$ Ibid.

${ }^{31}$ Ding Xianjie and Steven Yao Tang Lei "Protecting of Works of Applied Art under Chinese Judicial Practice" (2012) China Law Insight <www.chinalawinsight.com>.

${ }^{32}$ Ai Lu Mu International Inc v Huizhou Xin Li Da Electronic Tools Ltd Guangzhou Higher People's Court No 45 (2006)

${ }^{33}$ OKBaby Ltd, above n 28.
} 
Systems B.Vv Taizhou Zhongtian Plastic Co Ltd,${ }^{34}$ the court held that the children's stool in question did not significantly differ from regular children's stools and did not have a sufficient degree of artistic merit to be protected.

From the findings in the above cases, it does appear that the judicial consensus with respect to "works of applied art" is that a substantial degree of artistic merit is required. Although a Chinese academic specialising in intellectual property law (academic 'P') stated "I do not like such a requirement", they were nevertheless of the opinion that:

it is a realistic approach for the court to adopt. Since there is no separate category in the Copyright Law, the courts had to introduce such a requirement, in order to differentiate “works of applied art" from other ... works.

"Work of applied art" has, however, been included in the draft revision of the Copyright Law. The definition in the latest revision reads: “... toys, furniture, accessories and other two dimensional or three dimensional artistic works that possess both practical function and artistic merit." 35

Although this definition is consistent with the case law, academic ' $\mathrm{P}$ ' does not think 'the inclusion of examples is a good idea", rather they were of the opinion:

that examples are ... only needed to describe the characteristics and nature of the works of applied art. However, the drafters may not change ... this definition ... because if you look at the definitions of the other categories of work ... they also include examples.

\footnotetext{
${ }^{34}$ Inter IKEA Systems B.V v Taizhou Zhongtian Plastic Co Ltd Shanghai Intermediate People's Court No 187 (2008).

${ }^{35}$ The Copyright Law of the People's Republic of China 1991 (3rd draft revision, released on 1 October 2012), art 3.9.
} 
Charles Feng and Paul Ranjard explain that the examples within the definition are not restrictive, but, rather, included to illustrate the scope of the category. ${ }^{36}$ In this sense, the examples are arguably quite helpful.

A Chinese academic specialising in intellectual property law (academic 'Q') was even less impressed than academic 'P' with the proposed amendment, stating:

Introducing an explicit applied art category into [the] Copyright Law ... may break the

balance $\ldots$ between $\ldots$ art on the one hand and patent protection of $\ldots$ industrial designs

on the other hand.

Although it is indeed likely that the definition will be included in the Copyright Law in the future, as noted above, the judicial consensus in China is that copyright is not the appropriate legal mechanism for protecting typical industrial designs. ${ }^{37}$ Thus, patents will likely remain the main legal mechanism for protecting industrial designs.

\subsection{Patents}

In 1950, the communist party enacted the Provisional Regulation on the Protection of Invention Right and Patent Right. ${ }^{38}$ As with copyright, however, during the Cultural Revolution this law was abolished. ${ }^{39}$ When the Cultural Revolution came to an end after the death of Mao Zedong, the government established a working group of experts tasked with reintroducing a revamped, more internationally acceptable patent system, which finally came into force in $1984 .{ }^{40}$ The

\footnotetext{
${ }^{36}$ Charles Feng and Paul Ranjard "Final Draft of Proposed PRC Copyright Law Amendment Released by NCAC" (2013) Wan Hui Da <http://www.wanhuida.com>.

${ }^{37}$ Yunchuan, above $\mathrm{n} 23$, at 75 .

${ }^{38}$ Deming Liu "Now the Wolf Has Indeed Come! Perspective on the Patent Protection of Biotechnology Inventions in China (2005) 53 Am J Comp L 207 at 212.

${ }^{39}$ Ibid, at 216.

${ }^{40}$ Gabriel, above n 2, at 329.
} 
revamped patent system preceded the reintroduction of the revamped Copyright Law. This was because the patent system was seen as less likely to be utilised for the purposes of information control or propaganda than copyright. ${ }^{41}$ However, the patent system was nonetheless generally perceived negatively. Patent protection was not seen as a particularly important mechanism in China, due to the fact that science and technology were not traditionally considered to be respectable professions. ${ }^{42}$ Moreover, administration of patent licences was seen as slowing down modernisation efforts. ${ }^{43}$

As with the initially revamped Copyright Law, the Patent Law of the People's Republic of China 1984 ("Patent Law") had significant flaws, ${ }^{44}$ which were heavily criticised by the United States government. ${ }^{45}$ These flaws included the fact that the law had a very broad scope of compulsory licences, ${ }^{46}$ and the term of protection for utility model and design patents was only five years. ${ }^{47}$ Amendments have since been made to the law, the first of which came into force in $1993 .{ }^{48}$ Subsequent amendments came into force in 2000 for the purposes of harmonising Chinese law with the international requirements prescribed by the Trade-Related Aspects of Intellectual Property Rights Agreements (TRIPS). ${ }^{49}$ The most recent amendments came into effect in 2009. Today, the law in China is much less criticised by the United States and other Western countries. There are some elements of the Chinese patent system, however, that are still heavily criticised, but these mostly relate to enforcement. ${ }^{50}$ Intellectual property law

\footnotetext{
${ }^{41} \mathrm{Yu}$, above $\mathrm{n} 13$, at 212.

${ }^{42}$ Gabriel, above n 2, at 339.

${ }^{43} \mathrm{Yu}$, above $\mathrm{n} \mathrm{13}$, at 212.

${ }^{44}$ Gabriel, above n 2, at 330 .

${ }^{45} \mathrm{Ibid}$, at 331.

${ }^{46}$ Ibid, at 330 .

${ }^{47}$ Ibid, at 331.

${ }^{48}$ Ibid.

${ }^{49}$ Ibid, at 332.

${ }^{50}$ Ibid.
} 
enforcement is discussed in the final section of this chapter after the discussion of Chinese competition law. The next section outlines the three types of patent that are obtainable in China.

\subsubsection{Invention patents}

The types of patent that can be obtained in China are invention, utility model and design patents. From the three different types, the invention patent is the most difficult to acquire. To qualify for an invention patent, the invention must meet three requirements. It must be novel, creative and of practical use. ${ }^{51}$ The creativity requirement is analogous to New Zealand's “inventive step" requirement. ${ }^{52}$

The creativity threshold for an invention patent is significantly higher than it is for a utility model or design patent. ${ }^{53}$ This means that most industrial designs do not qualify for this protection mechanism. Utility model and design patents are usually more suitable for protecting industrial designs in China. However, there will always be some industrial designs that contain something truly inventive. ${ }^{54}$

When such industrial designs are also likely to be particularly useful or beneficial to the consumer, it may be worth acquiring the invention patent. An invention patent is the more substantial form of protection and protects the invention for 20 years, ${ }^{55}$ which is twice as long as the term provided for utility model and design patents.

\footnotetext{
${ }^{51}$ Patent Law of the People's Republic of China 1984 (as amended up to the decision of 27 December 2008, effective as of 1 October 2009), art 22.

${ }^{52}$ See Patents Act 2013 (NZ), s 7.

${ }^{53}$ Benjamin Liu "Chinese Patents as Copyrights" (2012) 34 Campbell L Rev 686 at 690.

${ }^{54}$ Examples of truly inventive industrial designs are provided in Section 3.3.1: Trade marks and patents.

${ }^{55}$ Patent Law of the People's Republic of China 1984, above n 51, at art 42.
} 


\subsubsection{Utility model patents}

Although the utility model patent is not as obviously catered to industrial design protection as design patents, it is clear from the definition of "utility model" provided in the Patent Law that many industrial designs come within the scope of this protection. ${ }^{56}$ Studies carried out in Brazil, the Philippines and Japan have indicated that effective systems for the protection of utility models can encourage innovation. ${ }^{57}$

\subsubsection{Scope}

The Patent Law provides that a utility model means "new technical solutions proposed for the shape and structure of a product, or the combination thereof, which are fit for practical use." 58 The term of protection for utility model patents is 10 years. ${ }^{59}$

\subsubsection{Requirements}

The basic requirements for a utility model patent are the same as those for an invention patent. A utility model that seeks patent protection must be novel, creative and of practical use. ${ }^{60}$ However, the creativity threshold for a utility model is significantly lower. The Patent Law states that creativity for a utility model means that it "possesses substantive features and

\footnotetext{
56 Patent Law of the People's Republic of China 1984, above n 51, at art 2.

$57 \mathrm{Yu}$, above $\mathrm{n} 13$, at 211.

${ }^{58}$ Patent Law of the People's Republic of China 1984, above n 51, at art 2.

${ }^{59}$ Patent Law of the People's Republic of China 1984, above n 51, at art 42.

${ }^{60}$ Patent Law of the People's Republic of China 1984, above n 51, at art 22.
} 
indicates advancements." ${ }^{61}$ Whereas for inventions it states that creativity means it "possesses prominent substantive features and indicates remarkable advancements" (emphasis added). ${ }^{62}$

There is no difference in the novelty requirement. Novelty, for both types of patents, is supposed to be determined in light of the worldwide prior art base. ${ }^{63}$ Although there is no difference in the novelty requirement, there is definitely a difference in the procedure for determining novelty. Mark Zhai explains that, in practice, when it comes to utility models, the absolute novelty requirement is treated as a mere formality. ${ }^{64}$ This is because there is no requirement that a substantive examination be carried out in respect of utility model patents. ${ }^{65}$

\subsubsection{Design patents}

Design patents are usually the most suitable protection mechanism for protecting industrial designs. The existence of a separate design patent system indicates that this is the intellectual property mechanism that is intended to protect typical industrial designs in China. ${ }^{66}$

\subsubsection{Requirements}

The Patent Law states: ${ }^{67}$

\footnotetext{
${ }^{61}$ Patent Law of the People's Republic of China 1984, above n 51, at art 22.

${ }^{62}$ Patent Law of the People's Republic of China 1984, above n 51, at art 22.

${ }^{63}$ Patent Law of the People's Republic of China 1984, above n 51, at art 22.

${ }^{64}$ Mark Zhai "The Chinese Utility Model Patent Is Destroying Innovation in China" (2011) 39 AIPLA Q J 413 at 423.

${ }^{65}$ See discussion on patent examination below in Section 4.2.4.

${ }^{66}$ Yunchuan, above n 23, at 75.

${ }^{67}$ Patent Law of the People's Republic of China 1984, above n 51, at art 2.
} 
Designs mean, with respect to a product, new designs of the shape, pattern, or the combination thereof, or the combination of the colour with shape and pattern, which are rich in an aesthetic appeal and are fit for industrial application.

There is a proposed amendment to the definition in the draft revision of the Patent Law, which replaces the words "a product" with the words "an overall product or its parts", ${ }^{68}$

The basic requirements for attaining a design patent are different to those of the invention and utility patents. There are only two basic requirements for a design patent. The first requirement of novelty is essentially the same as for the other two types of patent. The Patent Law states: ${ }^{69}$ A design for which the patent right is granted is not an existing design, and no application is filed by any unit or individual for any identical design with the patent administration department under the State Council before the date of application for patent right and no identical design is recorded in the patent documentations announced after the date of application .... For the purposes of this Law, existing designs mean designs that are known to the public both domestically and abroad before the date of application.

In addition to novelty, an industrial design that seeks to acquire design patent protection must be distinctive. The Patent Law states: ${ }^{70}$

Designs for which the patent right is to be granted shall be ones which are distinctly different from the existing designs or the combinations of the features of existing designs.

\footnotetext{
${ }^{68}$ See Patent Law of the People's Republic of China 1984 (4th draft revision, released on 10 August 2012), art 2.

${ }^{69}$ Patent Law of the People's Republic of China 1984 (2009), above n 51, at art 23.

${ }^{70}$ Patent Law of the People's Republic of China 1984 (2009), above n 51, at art 23.
} 
It is arguable that the requirement is inconsistent with the requirement prescribed by TRIPS, which requires designs to be "new or original" for registration. ${ }^{71}$

\subsubsection{Scope}

To infringe a design patent, the infringing design has to be of the same or similar type as the patented design. ${ }^{72}$ The term of protection for design patents is currently 10 years, ${ }^{73}$ but the draft revision of the Patent Law proposes that the term be amended to 15 years. ${ }^{74}$

\subsubsection{Patent examination}

In China a substantive examination is only explicitly required for invention patents. ${ }^{75}$ Applications for utility model and design patents, however, which are more analogous to New Zealand's registered design system, are subject only to a preliminary examination. ${ }^{76}$

The fact that only a preliminary examination is required for utility model and design patents means that they are significantly cheaper than invention patents. The standard filing fee for these patents is approximately one-seventh of that required for an invention patent. ${ }^{77}$ The turnover period for utility model and design patent applications is also significantly shorter than that of invention patents. The average registration process for invention patents is 22

\footnotetext{
${ }^{71}$ See Agreement on Trade-Related Aspects of Intellectual Property Rights (15 April 1994, entered into force 1 January 1995), art 25.

${ }^{72}$ See Jinjiang Qingyang Weiduoli Food Co v Zhangzhou Yueyuan Food Co Supreme People's Court No 1658 (2010).

${ }^{73}$ Patent Law of the People's Republic of China 1984 (2009), above n 51, at art 42.

${ }^{74}$ Patent Law of the People's Republic of China 1984 (2012), above n 68, at art 42.

75 See Patent Law of the People's Republic of China 1984 (2009), above n 51, at art 35.

${ }^{76}$ See Patent Law of the People's Republic of China 1984 (2009), above n 51, at art 40.

${ }^{77}$ Zhai, above n 64, at 423 .
} 
months, whereas the average registration process for utility model and design patents is 3 months. ${ }^{78}$

The major disadvantage of only having a preliminary examination is that the grant may only effectively serve as a placebo in the case of many industrial designs. ${ }^{79}$ For example, as many as $60 \%$ of utility model patents that are granted in China are eventually invalidated. ${ }^{80}$ Despite this high number, academic ' $\mathrm{P}$ ', thinks "a preliminary examination is enough. As there are so many applications ... the examinations should be fast".

Academic 'Q', on the contrary, believes:

the process should be more extensive and substantial than before, because ... as a result of ... too many applications being granted ... applicants in China already have an expectation that ... it is easy to get.

After stating their preference, academic ' $Q$ ' nevertheless noted that more substantive examinations are "unrealistic nowadays in China". The primary reason being that "SIPO [the State Intellectual Property Office of the People's Republic of China] is short of hands, with one examiner examining more than 3,000 applications per year."

\subsection{Overlapping Rights}

An industrial design can be protected under several intellectual property mechanisms in China. As noted above, design patents are the mechanism that is usually the most suitable for typical

\footnotetext{
78 State Intellectual Property Office of the People's Republic of China (SIPO) Intellectual Property Rights Protection in China (2015) at 5.

${ }^{79}$ The reason why it may serve as a placebo is explained in Section 6.2.3: Extent of examination.

${ }^{80}$ Zhai, above n 64, at 427.
} 
industrial designs. Many industrials designs also come within the scope of utility model patents. A few industrial designs may even meet the more stringent requirements for an invention patent.

The other protection option for some industrial design owners, as discussed above, is copyright. It is clear that some industrial designs can qualify for both patent and copyright protection. However, it is not expressly stated in either of the respective laws whether dual protection is permitted in China. Although the question has never been definitively determined, it has been previously indicated in court that the preferred presumption is that there is no evidence that the laws of China prohibit dual protection under patent and copyright. ${ }^{81}$

It may also be possible for an industrial design to retain protection after its copyright and/or patent has expired. Conduct which is actionable under the tort of passing off in New Zealand, is now also actionable in China under The People's Republic of China Anti-Unfair Competition Law 2017. ${ }^{82}$ This law will apply to few industrial designs however, as significant marketing and publicity is typically required for the design of a product to trigger, within the relevant public, an association with a particular source. ${ }^{83}$

\subsection{Competition Law}

Although competition law may sometimes be utilised as additional protection for industrial designs, it can also restrict the extent to which design owners can exercise their intellectual property rights.

\footnotetext{
${ }^{81}$ See Interlego AG v Keago Company Beijing Higher People's Court No 279 (2002).

${ }^{82}$ See The People's Republic of China Anti-Unfair Competition Law 2017 (promulgated by Order No 77) at art 6.

${ }^{83}$ Bai Wei and Zhang Bo "China: Comments on Multi-Protection of Works of Applied Art" (2018) Mondaq <www.mondaq.com>.
} 
The Anti-monopoly Law of the People's Republic of China 2008 ('Anti-monopoly Law') states: ${ }^{84}$

This Law does not govern the conduct of business operators to exercise their intellectual property rights under laws and relevant administrative regulations on intellectual property rights; however, business operators' conduct to eliminate or restrict market competition by abusing their intellectual property rights shall be governed by this Law.

Thus, the Anti-monopoly law is not triggered by the normal exercise of one's intellectual property rights, but will be triggered where intellectual property rights are abused.

Intellectual property, which is licensed out at high royalty rates, will not be usually deemed an abuse of exclusive rights. It can be, however, where the licensor is overly dominant in the market. ${ }^{85}$ Huawei $v$ InterDigital was a landmark case where the Guangdong High People's Court held (upon determining that InterDigital possessed standard essential patents) that InterDigital's high royalty rates did amount to an abuse of its intellectual property rights. ${ }^{86}$

Although there have been no cases on intellectual property rights abuse outside of instances where dominant players in the market sought excessive royalties, the State Administration for Industry and Commerce (SAIC) has published guidelines on other types of behaviour that will constitute intellectual property rights abuse. ${ }^{87}$ Examples include: unjustified refusal to licence intellectual property that constitutes a necessary facility for relevant production

\footnotetext{
${ }^{84}$ Anti-monopoly Law of the People's Republic of China 2008 (promulgated by Order No 68) at art 55.

${ }^{85} \mathrm{Gu}$ Minkang "Anti-Abuse of Intellectual Property Rights under the Anti-Monopoly Law: China's Approaches" (2015) 10 FLC 488 at 503.

${ }^{86}$ See Huawei v InterDigital Guangdong High People's Court No 306 (2013).

${ }^{87}$ See State Administration for Industry and Commerce Provisions on Prohibition of Abuse of Intellectual Property Rights to Exclude and Restrict Competition (2015).
} 
and operating activities, ${ }^{88}$ prohibiting licensees to trade with others ${ }^{89}$ bundling other products with the required intellectual property, ${ }^{90}$ and requiring licensees to licence back improved technologies. ${ }^{91}$ These behaviours are only likely to constitute abuse in instances where the intellectual property owner is dominant in the market. ${ }^{92}$ Most industrial design owners, due to the limited monopoly which they are able to acquire, ${ }^{93}$ are unlikely to attain such dominance.

\subsubsection{Spare parts}

Spare parts for industrial designs, which can be sold separately, are protected in China. ${ }^{94}$ As such, the owners of original industrial designs have a monopoly in the secondary market of spare parts. Academic 'Q' pointed out that "manufacturing and selling spare parts for protected industrial designs ... is not considered ... an exception to infringement."

Although there is currently no exception to limit such an extensive monopoly, academic ' $\mathrm{P}$ ' is of the opinion that "China should provide it, since there is a huge demand from industry."

This is clearly the case in the automobile industry. In 2014, complaints were made by Shanghai European car parts suppliers, with support from the European Union Chamber of Commerce in China. Companies such as Audi, Mercedes Benz, Daimler and BMW quickly reduced the

\footnotetext{
${ }^{88}$ Ibid, at art 7.

${ }^{89} \mathrm{Ibid}$, at art 8 .

${ }^{90}$ Ibid, at art 9 .

${ }^{91}$ Ibid, at art 10.

92 Ibid.

${ }^{93}$ See discussion above re the type of exclusive rights usually attainable by industrial design owners in Section 4.1: Copyright Law; and Section 4.2: Patents.

${ }^{94}$ China IPR "Understanding and Using China’s Design Patent” (2015) <www.china-iprhelpdesk.eu> at 2.
} 
prices of spare parts in response to these complaints. ${ }^{95}$ The companies' willingness to cooperate could arguably be seen as recognition of an impending threat. Perhaps they saw a compromise as being necessary to avoid a potential law reform, which could have required an even more substantial compromise by way of a "spare parts exception".

\subsection{Enforcement}

A far greater obstacle than the letter of the law (which is, as discussed above, continually improving) for New Zealand design owners doing business in China, is the actual enforcement of intellectual property laws. The discussion in this section explains the cultural and economic context that underpin the issue of intellectual property law enforcement in China.

In terms of enforcement of intellectual property law in China, some companies are very cynical. For example, an industrial designer at a design-driven company (company ' $G$ ') made the following comment:

If I ... put my work out there ... as I had as a young designer ... with the kind of copying industry there is today, coming out of China ... it would be gone, ripped off, made and manufactured, long before I could even get a toe in. When they first started making copies of our stuff, we employed a Chinese lawyer to try and stop it. They got written documents from the thieves saying "sorry we will not make any more, we promise", but they just keep on doing it. It is so endemic in China and is so much a part of their economy now that the government is not going to do anything about it. So the situation today is really, really bad for young designers.

\footnotetext{
${ }^{95}$ Colum Murphy "European Car-Parts Makers Support China Moves on Spare Parts; Firms Approve of Efforts to Loosen Auto Makers' Grip on Spare Parts” Wall Street Journal (online ed, New York, 9 September 2014).
} 
"You do have to be super careful", a multinational company (company 'F') pointed out, before explaining:

I mean culturally they just do not see ... intellectual property rights ... in the same way.

It is kind of like telling somebody to worry about something they have never previously thought about.

Indeed, traditionally, unauthorised copying was an acceptable practice in China. In fact, the act of copying an artist's work was typically perceived by the artist as a compliment. Copying signified an appreciation of the quality of the earlier work. ${ }^{96}$ Although Chinese designers traditionally replicated designs originating in their own country, with increased internationalisation they began copying designs from other countries as well. Yaonan Lin and Ching Lai explain that the copying of Western designs is a sign of Chinese designers' respect and admiration of work that they often perceive as being an exemplar of developed industry. ${ }^{97}$

Although this is the traditional perception of copying, China has, since 1981, adopted, as part of its endeavour to re-engage in world trade after the Cultural Revolution, ${ }^{98}$ an intellectual property system that is more synonymous with that of the Western world. ${ }^{99}$ Unauthorised copying however, is still an ongoing issue in some parts of China. The behaviour is perhaps appropriately explained by the famous Chinese proverb "the mountains are high and the emperor is far away" (shan gao huangdi yuan 山高皇帝远). Although it may be contrary to the will of the central government, some local economies in China have thrived from the production of counterfeit goods and are thus not readily willing to give this practice up,

\footnotetext{
96 William Alford To Steal a Book Is an Elegant Offence: Intellectual Property Law in Chinese Civilization (Stanford University Press, California, 1995) at 29.

97 Yaonan Lin and Ching Lai "A Study of the Attitudes of Chinese Consumers to Aesthetic Product Designs" (2010) 27 IJM 177 at 181.

${ }^{98}$ Gabriel, above $\mathrm{n} 2$, at 328 .

99 Jane Menzies and others "Intellectual Property, Business and China: Taking a Stand (2013) 18 Deakin L Rev 89 at 106.
} 
especially since they understand how difficult it is for the central government to keep track of production across China's large territory. ${ }^{100} \mathrm{~A}$ small portion of infringements can also be explained by an attitude shared by some intellectual property pirates, who believe their actions to be patriotic. They consider stealing intellectual property from Western countries (primarily the United States) as justified revenge for previous wrongs (both in the political and economic sense) committed against China. ${ }^{101}$

Although piracy continues, it is decreasing in scale. Berrell and Wrathall suggest that history has shown that the central government in China has been able to impose its will on the entire nation. Berrell and Wrathall point to the "one child policy" as an obvious example of this fact. ${ }^{102}$ Although this is true, it is important to remember that, since the Cultural Revolution, China has undergone some very significant societal restructuring. Of the changes made, decentralisation was perhaps the biggest factor to impact on the central government's ability to impose its will on the nation. Today, individual regions in China have far more autonomy. The administration of each region is today almost entirely in the hands of regional governments, and different regions have their own unique attributes as well as interests. ${ }^{103}$

In spite of this, one of the biggest and yet very common misapprehensions about China is that it is a homogenous nation. This misapprehension is reflected in much of the criticism regarding enforcement in China. Reported infringement numbers are too often lumped together and fail to distinguish between the intellectual property environments of different

\footnotetext{
${ }^{100}$ Bryan Mercurio "The Protection and Enforcement of Intellectual Property in China since Accession to the WTO: Progress and Retreat" (2012) 1 China Perspect 23 at 26.

${ }^{101}$ Jonathan Ocko "Copying, Culture, and Control: Chinese Intellectual Property Law in Historical Context" (2013) 8(2) Yale J L \& Human 559 at 575.

${ }^{102}$ Berrell and Wrathall, above $\mathrm{n} 14$, at 8 .

${ }^{103} \mathrm{Yu}$, above $\mathrm{n} 13$, at 204.
} 
regions. ${ }^{104}$ Peter $\mathrm{Yu}$ explains that such generalised criticism is not constructive and, if anything, is likely to have a damaging effect, particularly on the regions that have made great strides with respect to intellectual property rights. ${ }^{105}$ Generalised criticism fails to commend these regions on their efforts and achievements, and could very likely lead to a perception within these regions that the West will never be satisfied, irrespective of the effort made. ${ }^{106}$

Although coercive tactics such as those employed by the United States may have had a positive influence on the development of intellectual property law in China in the past, today it is no longer necessary and is, quite simply, the wrong tactic. One need only consider the development of the intellectual property systems in countries like Japan and Singapore to recognise that there is a pattern of development. ${ }^{107}$ Similarly to China, these countries initially began developing their intellectual property system in response to pressure from the United States. ${ }^{108}$ At a certain point in their economic development, however, these countries began to transform, and today both of these countries have strong intellectual property systems. The same pattern can even be observed in the history of the intellectual property systems in Germany and the United States. ${ }^{109}$ Yu reminds us that the United States was also once a former haven for pirated literary works of renowned British authors, including Charles Dickens and Anthony Trollope, amongst others. Yu explains that the pattern shows that, at a certain stage in development, there is a crossover point. ${ }^{110}$ It is the point when a country previously benefiting from having a weak intellectual property system reaches a stage in economic growth where it recognises that it is able to gain greater benefits by diligently enforcing intellectual

\footnotetext{
${ }^{104}$ Ibid, at 203.

105 Ibid, at 207.

106 Ibid.

${ }^{107}$ Ibid, at 202.

108 Wei Shi "Cultural Perplexity in Intellectual Property: Is Stealing a Book an Elegant Offence? (2006) 32 NCJ Int'l L \& Com Reg 1 at 35.

${ }^{109} \mathrm{Yu}$, above n 13, at 202.

${ }^{110}$ Ibid.
} 
property rights. ${ }^{111}$ At this point, a country quite rapidly turns from an intellectual property pirate to a champion of the system. ${ }^{112}$

A clear indication of China's intention to make that transition is evident in the Outline of the National Intellectual Property Strategy which was released in 2008, where it is stated: ${ }^{113}$ The level of the self-relied intellectual property will be higher by a large margin and the quantity of intellectual property will be greater. China will rank among the advanced countries of the world in terms of the annual number of patents for inventions granted to the domestic applicants, while the number of overseas patent applications filed by Chinese applicants should greatly increase. A number of world-famous brands will emerge. The proportion of the GDP accounted for by the value of core copyright industries will greatly increase ... The protection of IPRs will be significantly improved. Infringement of IPRs, such as piracy and counterfeiting, should be significantly reduced, the expense of protecting intellectual property right will decrease a great deal and abuse of intellectual property should be effectively curbed. The awareness of the IPRs in society, especially among market entities, will be greatly enhanced and a favorable intellectual property culture should be basically formed.

Understanding the pattern of economic development explained by $\mathrm{Yu}$ above, is important for those doing business in China. This is because effective legal as well as practical business strategies should accord with the particular stage of economic development. Yu describes China's current phase of development since the release of the Outline of the National Intellectual Property Strategy, as transformative. ${ }^{114}$ China's intellectual property protection

\footnotetext{
${ }^{111}$ Ibid, at 184.

112 Ibid, at 202.

${ }^{113}$ State Council of the People's Republic of China (SIPO) Outline of the National Intellectual Property Strategy (2008) at para 7.

${ }^{114}$ Peter Yu "When the Chinese Intellectual Property System Hits 35" (2018) 8 QMJIP 3 at 5.
} 
system is currently transitioning from what was by in large transplanted from foreign jurisdictions, to one that is more indigenous. That is, a system that is primarily influenced not by foreign pressures or incentives, but rather China's own cultural and economic interests. ${ }^{115}$

China's One Belt One Road initiative is testament to the fact that the Chinese Government has embraced its new position in the global economy. Much like other major developed countries before it, ${ }^{116}$ such as the United States, China is seeking to expand its business operations by utilising resources in mostly neighbouring countries, as well as a few more distant nations associated with the initiative. ${ }^{117}$ By investing in these countries, many of which are still developing, China emphasises via international instruments, such as free trade, ${ }^{118}$ arrangements that ostensibly benefit all parties involved. ${ }^{119}$ However, China's growing expectations with respect to intellectual property indicate that such arrangements are primarily aimed at benefiting China's interests. ${ }^{120}$

Some of the key government initiatives that have been implemented in pursuance of the objectives set out in the Outline of the National Intellectual Property Strategy, ${ }^{121}$ are outlined below. The subsequent section illustrates how these government initiatives, and the legal developments discussed above, have culminated in the transformation of culture with respect to intellectual property within the business world and society in general.

\footnotetext{
115 Ibid.

116 Jyh-An Lee "The New Silk Road to Global IP Landscape" in Lutz-Christian Wolff and Chao Xi (eds) Legal Dimensions of China's Belt and Road Initiative (Wolters Kluwer, Hong Kong, 2016) 417 at 421.

${ }^{117}$ Ibid, at 420.

${ }^{118}$ Vivienne Bath "One Belt, One Road and Chinese Investment” in Lutz-Christian Wolff and Chao Xi (eds) Legal Dimensions of China's Belt and Road Initiative (Wolters Kluwer, Hong Kong, 2016) 165 at 173.

${ }^{119}$ Ibid, at 168 .

${ }^{120}$ Ibid, at 173 .

${ }^{121}$ See SIPO, above n 113.
} 


\subsubsection{Educating the public}

Education is a key element of the conversion process and indeed China is expending significant resources to re-educate Chinese society about intellectual property law. This route is very much consistent with Confucian philosophy, which advocates for the use of persuasion and education in encouraging appropriate conduct. ${ }^{122}$

The famous proverb "the mountains are high and the emperor is far away" (shan gao huangdi yuan 山高皇帝远) is effectively a description of a fundamental characteristic of human psychology. When people are threatened with punishment for engagement in a certain activity, they are likely to refrain from that activity as long as they are being watched, or while they believe that they are likely to be caught. As soon as they no longer believe they will be caught, however, they may actually become even more willing to engage in the forbidden activity than they would have otherwise. That is because no reason was provided for the forbiddance. ${ }^{123}$ Thus, the threat of punishment serves as the only deterrent. A much more effective deterrent is one's own values and beliefs. Thus, instead of a threat, the key is to provide a reason for the request or rule. When the receiver is taught and convinced that the rule is important, the rule becomes incorporated into their own values and belief system. At that point, neither threat nor surveillance is necessary. ${ }^{124}$ To be persuasive, the explanation provided must be capable of being perceived as culturally acceptable. ${ }^{125}$ In the process of reform to modernise the Chinese legal system, Deng Xiaoping promoted Western ideas, but only to the extent that they were consistent with "the Chinese way of doing things"

\footnotetext{
${ }^{122}$ Berrell and Wrathall, above n 14, at 9.

${ }^{123}$ Robert Caldini Influence Science and Practice (5th ed, Pearson Education, New York, 2009) at 82.

124 Ibid, at 83.

$125 \mathrm{Yu}$, above n 13, at 191.
} 
(quoquing 国情). ${ }^{126}$ Thus, it is politically important that the establishment of an intellectual property system is backed by rhetoric closely aligning with Chinese culture and tradition. ${ }^{127}$ Although the Chinese system can be described as capitalist, it is important to note that it is a unique capitalist environment. It is still very much intertwined with Marxist philosophies. ${ }^{128}$ For this reason, personality-based theories that stress non-property-based justifications for the protection of intellectual property are likely to be attractive to Chinese policy-makers. ${ }^{129}$ However, it is social planning theory that is arguably the most consistent with the unique political environment of China. Although it has a significant utilitarian aspect, which underpins a typical capitalist system, its overall objective of a desirable society is much more consistent with Marxist objectives than it is with the "social welfare" concept of utilitarianism. ${ }^{130}$

There are currently several means through which the public is being taught about the value and importance of the intellectual property system for China's development. One of the most obvious contributors in the education process are Chinese intellectual property lawyers who provide advice about the importance of protecting intellectual property, ${ }^{131}$ but the availability of legal advice is only the tip of the iceberg. By the end of 2016, SIPO had approved 24 intellectual property rights training bases for business across 19 provinces. Moreover, in conjunction with the Ministry of Education, SIPO had, by the end of the same year, launched intellectual property rights education programmes in 30 different primary and middle schools across 25 different provinces. ${ }^{132}$ The latter initiative is likely to prove most

\footnotetext{
${ }^{126}$ Berrell and Wrathall, above n 14, at 11.

${ }^{127} \mathrm{Yu}$, above $\mathrm{n} \mathrm{13}$, at 191.

${ }^{128}$ Berrell and Wrathall, above n 14, at 8.

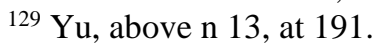

${ }^{130}$ Ibid.

131 Zhengzhi Wang (ed) China Intellectual Property Index Report (prepared by the China Intellectual Property Index Research Group, 2014) at 6.

${ }^{132}$ SIPO, above n 19 , at 32.
} 
fruitful, as, from a psychological standpoint, education for the purpose of establishing core values is much more effective in the earlier stages of life, since a commitment to prior-held beliefs and prejudices is far less developed in children than in adults.

\subsubsection{Media and publicity}

In addition to the education initiatives, intellectual property rights are also heavily promoted in the Chinese media. For example, in 2016, SIPO, in conjunction with 23 government departments, organised over 70 publicity events. Moreover, approximately 20,000 news reports relating to intellectual property rights were published nationwide over the course of the year. ${ }^{133}$

\subsubsection{Accessibility to and transparency of the intellectual property legal system}

China has also taken significant steps to make the intellectual property system more accessible. In 1993, the first specialised intellectual property courts were established at the Intermediate and Higher People's Court levels in Beijing. In the following year, specialised intellectual property courts were also established in Shanghai as well as the Guangdong, Fujian and Hainan provinces. There are also special collegial panels set up for hearing intellectual property cases in the capital cities of the other provinces, in municipalities and in autonomous regions. ${ }^{134}$ More specifically for industrial designs, special prosecution centres have been established in eight industrial clusters in recognition that a quick dispute resolution process is required in these industries so as not to stifle economic growth. ${ }^{135}$

\footnotetext{
${ }^{133}$ Ibid, at 27.

${ }^{134}$ Kolton, above $\mathrm{n} 1$, at 436.

${ }^{135}$ SIPO, above n 19, at 22.
} 
In more recent times, the judiciary has been taking positive steps to increase the transparency of these specialised courts. For example, in 2014, in the Guangdong province, various media outlets were invited to an intellectual property trial and were provided the opportunity to conduct in-depth interviews. In the same year, the Shanghai Intellectual Property Court held a press conference inviting more than 40 Chinese and foreign reporters, as well as the United States and European Chambers of Commerce, to discuss recent trials and other intellectual property-related issues. ${ }^{136}$

\subsubsection{Cooperative efforts}

To ensure continual improvement with regard to intellectual property rights enforcement, Chinese intellectual property courts have expanded their communication channels and are increasingly cooperating with administrative, cultural and industry bodies. ${ }^{137}$

The Ministry of Public Security (MPS) is also engaged in enhancing cooperation with administrative bodies through intelligence exchange and interdepartmental information sharing. It is also in cooperation with prominent corporations in the online market, such as Alibaba, to provide for a rapid inquiry process into online intellectual property rights infringement. ${ }^{138}$

\footnotetext{
${ }^{136}$ White Paper on the Status of the Judicial Protection of Intellectual Property Rights in Chinese Courts in 2014 (released by the Supreme People's Court of the People's Republic of China 2015) at [15].

${ }^{137}$ Ibid, at [13].

${ }^{138}$ SIPO, above n 113, at 25.
} 


\subsubsection{Enforcement success thus far and plans for the future}

In 2016, SIPO released a report revealing enforcement statistics with respect to intellectual property infringement. ${ }^{139}$ "The statistics in ... SIPO reports are reliable, since SIPO is authorised as the government organ ... to deal with issues concerning infringement of intellectual property", academic 'P' explained. "They are useful indeed”, noted academic 'Q', before elaborating:

They demonstrate ... which ... intellectual property rights are vulnerable to infringement, the forms and means of infringement, the consequences brought by infringement, etc. The reports shows us aspects we have done well ... and aspects we still need to improve on.

The 2016 report revealed that administrative law enforcement bodies investigated and processed 189,000 alleged intellectual property rights infringement cases, ${ }^{140}$ with 10,431 suspects being prosecuted in courts nationwide, and 10,334 people being found guilty of infringement. ${ }^{141}$

The China Intellectual Property Index Report, released in 2014 by the China Intellectual Property Index Research Group, outlines the degree of intellectual property protection in different regions. ${ }^{142}$ One of their primary objectives in putting together the report was to provide a dependable snapshot of the environment for foreign investors and business. ${ }^{143}$ The report revealed that eastern China has the strongest intellectual property rights protection, with 6 of the top 11 ranked cities located in the east. The north is much weaker in intellectual

\footnotetext{
${ }^{139}$ See SIPO, above n 19.

${ }^{140} \mathrm{Ibid}$, at 8.

${ }^{141}$ Ibid, at 10 .

${ }^{142}$ See Wang, above n 131.

${ }^{143}$ Ibid, at 38 .
} 
property protection, with Beijing being the exception. ${ }^{144}$ This is because the central government is located in Beijing and thus they are in the position to more closely monitor behaviour in the immediate territory. As was explained above, with reference to the famous Chinese proverb, and as illustrated by the statistics, it is much harder for the government to impose its will when its subjects are further away. For that reason, the entire western region, both in the north and in the south, remains very weak in terms of intellectual property rights protection. ${ }^{145}$

Rather than reliance on policing and monitoring, it will be the other measures currently being implemented in China, such as education, publicity and accessibility, as discussed above, that should prove more fruitful and lead to stronger intellectual property protection in these regions in the future.

That is not to say, however, that more stringent enforcement measures are not being planned by the central government for the future. An example of just that is the significant increase in damages that has been proposed in the latest draft revision of the Copyright Law. ${ }^{146}$ The motive behind the continuing expansion of enforcement measures is the growing realisation in China that a strong intellectual property rights system is vital for the continuation of the country's rapid economic growth. ${ }^{147}$

\footnotetext{
${ }^{144} \mathrm{Ibid}$, at 31 .

${ }^{145}$ Ibid.

${ }^{146}$ Hong Xue "A User-Unfriendly Draft: 3rd Revision of the Chinese Copyright Law" (2012) 7(4) JICLT 350 at 355.

${ }^{147}$ White Paper, above n 136, at [16].
} 


\subsection{Transformation in Culture with Respect to Intellectual property}

Aside from economic growth, it is clear that the government initiatives discussed above as well as the developments in the letter of the law are influencing a transformation in culture. Business persons as well as the general public in China are increasingly recognising the value of, and need for, intellectual property protection.

In the business world, China is today “... in its third generation of manufacturing. They are building products themselves and for the world, with their own brands", a multinational company (company 'B') explained. It is thus arguable that the turning point from pirate to intellectual property champion, has already occurred. The change, however, is evident in some regions more than others. "I travelled all over", an industrial designer at company 'F' stated. During their travels in China, they observed that "further north of Shanghai, it can be a little bit hit and miss. Around Shanghai and south is ok." However, they also stressed that making any kind of blanket statement with respect to most areas "would be ... a generalisation .... I visited a whole lot of factories in the small areas. Some of them were great and some ... were terrible."

It is clear, however, that Chinese companies are increasingly recognising the importance and value of intellectual property. A multinational company that has partaken in joint ventures with Chinese companies (company 'E') commented: "They were interested in us because of our innovations and our ability to create different and better products." 
"It is changing in China now. A lot of companies ... are changing their business strategy", a furniture design company (company ' $\mathrm{H}$ ') pointed out, before providing the following example from their own experience:

We are now dealing with ... a Chinese-based company. They are young ... industrial designers $\ldots$ all in their early thirties ... designing and selling ... unique, authentic furniture ... in beautiful fashion ... all over the world. They have gone out into the world and they have come back to Shanghai and said "we want to make furniture in the way our ancestors did. We are sick of China being labelled a cheap replica manufacturing area."

Many Chinese companies, including Lenovo, Huawei and ZTE, have a crucial interest in China having an effective intellectual property system. ${ }^{148}$ Moreover, many Chinese companies, particularly in the high-tech industries, expect foreign companies that want to collaborate in business ventures to have registered patents. Patents are perceived by many local Chinese companies as an indication of substantial research and development. ${ }^{149}$ Thus, many of these companies will simply have no interest in doing business with foreign businesses that do not have this intellectual property. ${ }^{150}$ This should come as no surprise when one also factors in government incentives. "The local governments always introduce some policies to stimulate the company ... to apply for more patents", academic 'Q' explained, in pointing out that a common measure of "performance ... in China ... is the number of patents applied for and obtained".

Although the general public may not be as well versed in the concept of intellectual property as business persons, the new generation today is certainly more aware of intellectual property

\footnotetext{
148 Oliver Gassmann, Angela Beckenbauer and Sascha Friesike Profiting from Innovation in China (SpringerVerlag, Berlin, 2012) at 21.

${ }^{149} \mathrm{Ibid}$, at 28 .

${ }^{150}$ Ibid.
} 
than their parent or grandparents. ${ }^{151}$ For example, recognition of valuable brands is growing in China. Company 'H' explained:

The middle class is changing. For example, Kartell ... have started opening flagship stores with their brand, right throughout China, and that has helped. Now the local people ... understand ... what the original brand is all about.

For generations born post-Mao and since the initiation of Deng Xiaoping's economic reform in 1978, brands and especially Western brands are seen as an indication of one's status in society. ${ }^{152}$ "The middle class in China are brand hungry", company 'H' commented. "All of a sudden people think 'why should we buy a cheap copy when we can go and buy an original?'"

Outside of valuable brand recognition however, there seems to be little knowledge about, or interest in intellectual property rights among the general public in China. This is evident, for example, from the low public attendance at intellectual property trials in China, which is in stark contrast to that of criminal trials. ${ }^{153}$ There is often substantial public attendance at criminal trials, because traditionally the Chinese public perceive these as being important for societal stability, unity and peace. ${ }^{154}$ With all of the government initiatives, discussed above, ${ }^{155}$ in place, it is likely that knowledge of, and interest in, intellectual property rights will increase as the younger generations reach adulthood.

\footnotetext{
${ }^{151} \mathrm{Yu}$, above $\mathrm{n} 114$, at 11.

152 Noreen O'Leary “Keeping up with the Jiangs” (2007) 48 Brandweek 14 at 15.

${ }^{153}$ Haien Shen and Xiaohong Wen "The Reform of the Chinese Intellectual Property Trial System" (2016) 5 GJCL 68 at 74.

154 Ibid.

${ }^{155}$ For example, education in intellectual property is now being taught from as early as primary school - see discussion above in Section 4.5.1: Educating the public.
} 
$\mathrm{Yu}$ explains that increased public consciousness of the importance of intellectual property rights is a vital component of an effective intellectual property system in practice. ${ }^{156}$ Although the government initiatives that have been put in place thus far, look promising in increasing public consciousness, it is important to bear in mind that the Chinese Government heavily sensors the information that is available to the public. ${ }^{157}$ The information on intellectual property rights that can be accessed by the general public in China, may therefore be limited.

Although protection of industrial designs is continually improving in China, New Zealand industrial design owners should implement non-legal strategies in addition to acquiring legal protection. Taking into account the issues identified in this chapter, Chapter 7 provides suggestions and recommendations for how to appropriately protect industrial designs in China.

\footnotetext{
${ }^{156} \mathrm{Yu}$, above $\mathrm{n} 114$, at 11.

${ }^{157}$ Peter Yu "Five Oft-repeated Questions About China's Recent Rise as a Patent Power" (2013) Cardozo L Rev 78 at 111.
} 


\section{Impact of Advances in Technology on Industrial Design Protection}

This chapter identifies contemporary technological advances and discusses their impact on New Zealand's industrial design law. Technological advances in virtual designs are discussed first. The main types of virtual designs are identified and each is explained in turn. An examination of the extent to which each type is provided protection under copyright and the registered design system follows. Subsequently, 3D printing and the implications of this technology is discussed. Where relevant, the approach China has taken in response to technological advances is also noted.

\subsection{Virtual Designs}

The presence of virtual designs and their impact on society is rapidly becoming a phenomenon of interest. ${ }^{1}$ In simple terms, virtual designs are developed by humans, but are observable in a digital, rather than the physical or material, environment. A more thorough explanation and discussion of the different types of virtual designs, namely graphic user interfaces (GUIs), computer generated imagery (CGI) and multisensory designs, is provided below.

\subsubsection{Graphic user interfaces}

The earliest GUIs were those introduced in Xerox's Alto, which was created in 1973. The Alto was arguably the first personalised computer. Prior to the Alto, human interaction with computers was limited to code. Users had to either directly type codified instructions to the

\footnotetext{
${ }^{1}$ Stephen LaValle Virtual Reality (Cambridge University Press, Cambridge, 2019) at 32.
} 
computer, or select from a list of command codes. ${ }^{2}$ Before GUIs, there were no images on the screen with which the user could interact. The Alto provided the first software that virtually replicated the office desk, by displaying image icons representing things commonly found around the office desk, such as folders and trashcans. ${ }^{3}$

In 1979, Steve Jobs visited the research facility where the Alto was created. He was so impressed by the virtual desktop that he obtained a licence to incorporate it into the software of Apple Incorporated's ("Apple") then two personal computers, namely Apple II and the Lena. ${ }^{4}$ Virtual desktops have been included in all Apple computers ever since. Seeing its success, other software companies, such as the Hewlett-Packard Company and Microsoft Corporation, quickly followed suit and obtained licences to incorporate the virtual desktop into their systems as well. ${ }^{5}$ Today, the virtual desktop has transcended computers, and different variants of it can be observed in a multitude of electronic products, such as smartphones, smartTVs and tablets. ${ }^{6}$ Aside from virtual desktops, there are many other common GUIs, such as websites and game menus.

\subsubsection{Computer generated imagery}

CGI, as the name suggests, is any imagery generated on a computer. Obvious examples of CGI are object and character designs, which are generated on the computer for games and films.

\footnotetext{
${ }^{2}$ Rachel Stigler "Ooey GUI: The Messy Protection of Graphical User Interfaces" (2014) 12(3) Nw J Tech \& Intell Prop 215 at 219.

${ }^{3}$ Ibid.

${ }^{4}$ Ibid.

${ }^{5}$ Ibid, at 220

${ }^{6}$ Ibid, at 217.
} 
Other examples include models of hypothetical concepts or representations of physical materials generated on the computer by people working in various scientific fields. ${ }^{7}$

With advances in technology, CGI design is continuously improving the user's experience of the digital world. Cinema and gaming have come a long way from the time of black and white silent movies and Pong. The virtual experience is further enhanced through new technologies such as the Oculus Rift or the HTC Vive, which are headset devices strapped over the user's eyes, providing them with 360 degree virtual reality vision. ${ }^{8}$ The first virtual reality headset was invented in the mid-1960s by Ivan Sutherland. ${ }^{9}$ The CGI of the 1960 s was so drastically out of tune with natural perception, however, that the user was not able to keep the headset on for extended periods of time without experiencing disorientation or motion sickness. ${ }^{10}$ The CGI design utilised in the Oculus Rift and the HTC Vive today are substantially better in this respect (although there have been recent reports of some sensory discomfort). ${ }^{11}$

\subsubsection{Multisensory design}

The latest version of the Oculus Rift is likely to be a revolutionary phenomenon in far more than just gaming. The founder of Facebook, Mark Zuckerberg, has purchased the technology, seeing it as a future communication platform. ${ }^{12}$

\footnotetext{
${ }^{7}$ For example, see Stéphanou Angélique "An integrated computational approach for the design of patient-specific virtual tumours" (paper presented to New Mathematical and Computational Problems Involved in Cell Motility, Morphogenesis and Pattern Formation Seminar, Cambridge, 7 December 2015); and Peter Challenor "Experimental Design for Inverse Modelling: From Real to Virtual and Back" (paper presented to UQ for Inverse Problems in Complex Systems Seminar, Cambridge, 11 April 2018).

${ }^{8}$ Elli Cho "Copyright of Trade Dress toward IP Protection of Multisensory Effect Designs for Immersive Virtual Environments" (2015) 33 Cardozo Arts \& Ent L J 801 at 807.

${ }^{9}$ Ibid, at 809.

${ }^{10} \mathrm{Ibid}$, at 806.

${ }^{11}$ Betsy Mason "Virtual reality has a motion sickness problem" Science News Magazine of the Society for Science \& the Public (online ed, Washington, 7 March 2017).

${ }^{12}$ Brian Solomon "Facebook Buys Oculus, Virtual Reality Gaming Startup, for \$2 Billion” Forbes (online ed, New York, 25 March 2014).
} 
The technology has the potential for adoption across all kinds of sectors and industries, from home entertainment to military training. ${ }^{13}$ This vast potential capacity of the Oculus Rift suggests there will be substantial investments made to further develop the technology, transforming it from an audiovisual virtual experience into a multisensory virtual reality.

The HTC Vive is the other major device that is at the forefront of virtual reality technology. A company in the virtual reality field (company ' $R$ ') utilises the HTC Vive in their work. In terms of the extent to which it is already able to provide a multisensory experience, company ' $R$ ' stated the following:

There is technology for tracking your whole body's movements. You have hand trackers and then you can have trackers that track your elbows, your knees, or even your hips, if you want to get that intense. There is also leap motion, which is where you put a sensor on the front of the headset and then there are also gloves that you can put on for haptics (tactile interaction). We will use all the technology that is right for the experience we are writing about.

The original "data glove" dates back to $1987,{ }^{14}$ and like the original headset the original data glove was also ahead of its time. The data glove was designed to be worn for the purpose of providing the user with a realistic touch feedback mechanism in a virtual reality environment. However, the technology, which could fit inside a glove without restricting comfort or motion, was insufficient to provide the hand with a sensation that could fool the mind into believing that interaction with some digital (physically non-existent) object was taking place. ${ }^{15}$

\footnotetext{
${ }^{13}$ Cho, above $\mathrm{n} 8$, at 804 .

${ }^{14} \mathrm{Ibid}$, at 810 .

${ }^{15}$ Darwin Caldwell, Suzanne Lawther and Andrew Wardle "Tactile perception and its application to the design of multi-modal cutaneous feedback systems" (paper presented to International Conference on Robotics and Automation, Minnesota, April 1996) at 3218.
} 
In 2009, a data glove was released onto the market that could accurately record the precise motions of the sensory points of a hand, such as the palm and fingertips, in $3 \mathrm{D} .{ }^{16}$ Today, the data glove when utilised in conjunction with other sensory effects is already capable of tricking the user's brain into believing it is experiencing certain sensations. "Archery is a good example”, noted company ' $\mathrm{R}$ ', before elaborating:

There is a game where you literally hook the thing and it vibrates as you pull it back. Increased vibration and the sound correlation tricks your mind into feeling more strain the further back you pull it.

"There is currently a lot of work around perceptual tricks", a design academic specialising in virtual reality (academic ' $S$ ') pointed out, before elaborating:

Instead of having you turn 90 degrees, you turn 87 degrees, and they will keep you doing that to keep you in a small space, while you think you are exploring a large space, those kinds of things.

In terms of perceptual tricks, specifically with respect to haptics, academic ' $S$ ' stated "my favourite example is the button on the iPhone 7. Although it feels like it moves, it does not actually move. It is completely solid."

Haptic capabilities in virtual reality are still fairly limited, however, as academic ' $\mathrm{S}$ ' explained: Although there is some work in virtual reality, with respect to haptics, it is primarily sound and images, projected into space. Since technology like the Kinect, we can pretty much look at a hand and understand where the skeleton is. We understand how it is grabbing and how it is moving and all those kinds of things. So you can reach out and grab things that are not there. The technology can sense the relationship of the hand to

\footnotetext{
${ }^{16}$ Cho, above $n 8$, at 810 .
} 
the digital item, but you cannot feel it. Your hand will pass right through it, because it is really a ghost.

Haptic sensations will be an important component of virtual reality in the future. Company ' $R$ ' pointed out that:

Gloves are currently being developed. So in the future, we will have gloves, which will allow us to pick up digital assets. For example, you may pick up a vase and that will trigger the gloves to produce certain sensations. It may be hot or cold, or it may have a scratchy texture.

The future of the multisensory design is likely to utilise such glove technology in conjunction with the headset to provide an enhanced virtual experience. ${ }^{17}$ In the opinion of company ' $R$ ', "the technology is still 5 to 10 years away." The reason why this technology is likely to still be a few years away is that touch is perhaps the most complex of the human senses, as it is connected to a vast array of nerve types. ${ }^{18}$

It is also worth noting that haptic technology is not limited to sensory feedback for the hands. "It is a full immersion situation. They already have a vest you can wear. So if your game character gets rugby tackled, you can actually feel the impact", a company in the virtual reality field (company ' $\mathrm{T}$ ') pointed out. Elli Cho also describes other developing technology that is likely to enhance the virtual experience, such as virtual reality masks, which are designed to strap onto the audiovisual headset. ${ }^{19}$ For the sensation of smell, such masks can blast different scents into the user's nostrils. They can also project cool or heated air and can even expel

\footnotetext{
${ }^{17}$ Ibid, at 809.

${ }^{18}$ Caldwell, Lawther and Wardle, above n 15, at 3216.

${ }^{19}$ Cho, above $n 8$, at 809 .
} 
moisture onto the cheeks for further sensations. ${ }^{20}$ The cheeks are an ideal location to produce such sensations, as skin is most sensitive on the face and fingertips. ${ }^{21}$

Multisensory design is still quite limited with respect to senses other than visual or auditory. However, it is very likely that simulation technology with respect to the other human senses will eventually be developed.

The extent to which virtual designs are protected as intellectual property is examined below. The discussion also considers multisensory design that is anticipated to be developed in the near future.

\subsubsection{Copyright in virtual designs}

"As I understand it, digital imagery is protected under copyright law", a company that designs children's products (company 'J') stated, in regard to New Zealand copyright law. A legal advisor specialising in intellectual property (legal advisor 'L') was of the same opinion, stating: "I think virtual designs are probably ... appropriately protected by copyright."

Software is included in the definition of literary work in copyright law. ${ }^{22}$ A Chinese academic specialising in intellectual property law (academic 'Q') pointed out that, in China, "GUIs can be protected by copyright law, as software."

\footnotetext{
${ }^{20}$ Ibid.

${ }^{21}$ Caldwell, Lawther and Wardle, above n 15, at 3216.

22 See Agreement on Trade-Related Aspects of Intellectual Property Rights (15 April 1994, entered into force 1 January 1995), art 10; and Copyright Act 1994 (NZ), s 2(1).
} 
It is not clear, however, to what extent GUIs and other virtual designs can be protected separately from their underlying code. For the purposes of copyright, it is the underlying code that is protected as a literary work. Code communicates with the computer and virtual designs are what is displayed on the screen as a result of that communication. The human user, in turn, views and interacts with the virtual designs displayed. ${ }^{23}$

A company in the virtual reality field (company ' $U$ ') explained why it is problematic for copyright to protect only the underlying code, stating:

If we carve something using CNC [Computer Numerical Control], draw it on the screen, and then carve it out, it is just a bunch of numbers to a machine, but we could do it another way, and it would be a different set of numbers. So if it is a different set of numbers, how would it be protected?

Company ' $\mathrm{T}$ ' noted a similar problem, stating:

We produce instructions for customisable designs that lead to a whole range of forms and colours, from the same code. So the same code defines a whole range of results.

This is an issue very similar to that which was raised in the United Kingdom case of Nova Productions Ltd v Mazooma Games Ltd \& others and Bell Fruit Games Ltd ('Mazooma Games'), ${ }^{24}$ which concerned a computer pool game. Although the software code in the allegedly infringing game was different, the game design displayed on screen was visually very similar. However, the Court of Appeal did not find that infringement by copying had occurred with respect to the visual display either. This was because as a graphic work the visual displays could only be compared in the form of a non-moving or a series of non-moving stills. ${ }^{25}$ As

\footnotetext{
${ }^{23}$ Stigler, above n 2, at 219.

${ }^{24}$ Nova Productions Ltd v Mazooma Games Ltd \& others and Bell Fruit Games Ltd [2007] EWCA Civ 219.

${ }^{25}$ Ibid, at [16].
} 
there was no frame-by-frame reproduction, the Court of Appeal held that there was no substantial reproduction of the visual display. ${ }^{26}$

In the United States, however, virtual designs are protectable independently of the software code as "audiovisual works". ${ }^{27}$ To date, copyright in virtual designs has not been an issue before New Zealand courts. However, unlike the United States, New Zealand does not list "audiovisual works" as a category of works that are protectable by copyright. Thus, the question is, if New Zealand courts are willing to recognise copyright in virtual designs independently of the software code, what type of work, for the purpose of the Copyright Act 1994 (Copyright Act), are they?

\subsubsection{Applicable category}

This is not an issue that has come before the courts in New Zealand. However, in the United Kingdom, GUIs have been held to be artistic works. ${ }^{28}$ Martin Howe and his co-authors explain that virtual images can never be considered to be photographs, ${ }^{29}$ which are "artistic works" for the purposes of copyright, ${ }^{30}$ because the definition of "photograph" requires the image to be a "recording of light or other radiation". ${ }^{31}$ Although Howe et al make this observation in relation to the United Kingdom's Copyright, Designs and Patents Act 1998 (CDPA), it is true by analogy for New Zealand, which has essentially the same definition of "photograph" in its

\footnotetext{
${ }^{26}$ Ibid, at [18].

27 “'A Audiovisual works' are works that consist of a series of related images which are intrinsically intended to be shown by the use of machines, or devices ... together with accompanying sounds, if any, regardless of the nature of the material objects ... in which the works are embodied" - see Copyright Law 17 USC $\S 101$.

${ }^{28}$ See Navitaire Inc v EasyJet Airline Co Ltd [2004] EWHC 1725.

${ }^{29}$ Martin Howe, James St Ville and Ashton Chantrielle Russell-Clarke and Howe on Industrial Designs (9th ed, Sweet \& Maxwell, London, 2016) at [5-012].

${ }^{30}$ See Copyright Act 1994 (NZ), s 2(1).

${ }^{31}$ Howe, St Ville and Chantrielle, above n 29, at [5-012].
} 
Copyright Act. ${ }^{32}$ However, Howe et al suggest that virtual images can be categorised as "graphic works", ${ }^{33}$ for the purposes of copyright. ${ }^{34}$ A New Zealand legal practitioner specialising in intellectual property (legal practitioner ' $\mathrm{O}$ ') was also of the opinion that virtual designs "are 'graphic works' that fall under 'artistic works'."

Some virtual objects, most virtual characters, and certainly most if not all GUIs, however, are animated rather than simply static. Therefore, unless there is a frame-for-frame reproduction of the GUI, a claim of infringement of a GUI as a graphic work will fail, as Jacob L J explained in Mazooma Games. ${ }^{35}$ For this reason, Kevin Garnett and his co-authors suggest that a GUI would more accurately be described as a "film". "Film" is defined in the CDPA as a "recording on any medium from which a moving image may by any means be produced." Thus, Garnett et al explain, the definition embraces digital products, including computer programs. ${ }^{36}$ The definition of "film" in the CDPA is essentially the same as in the Copyright Act. ${ }^{37}$

In her discussion of still shots from security camera footage, Susy Frankel explains, with reference to the United Kingdom decision in Hyde Park Residence Ltd v Yelland News Group Newspapers Ltd, that still shots can be considered a breach of a film as a whole. ${ }^{38}$ Thus, for a claim of infringement of copyright in film, there does not need to be a frame-for-frame reproduction. In the United Kingdom, however, a "film" is not required to be "original" for the purposes of copyright protection, ${ }^{39}$ the reason being that there could be more than one recording

\footnotetext{
${ }^{32}$ See Copyright Act 1994 (NZ), s 2(1).

${ }^{33}$ Howe, St Ville and Chantrielle, above n 29, at [5-013].

${ }^{34}$ See Copyright Act 1994 (NZ), s 2(1).

${ }^{35}$ Nova Productions, above n 24, at [18].

${ }^{36}$ Kevin Garnett, Gillian Davies and Gwilym Harbottle Copinger and Skone James on Copyright (16th ed, Sweet \& Maxwell, London, 2011) at [26-369].

${ }^{37}$ See Copyright Act 1994 (NZ), s 2(1).

${ }^{38}$ Susy Frankel "The Copyright and Privacy Nexus" (2005) 36 VUWLR 507 at 517. See also Hyde Park Residence Ltd v Yelland News Group Newspapers Ltd [2001] 2 Ch 143 (CA).

${ }^{39}$ See Copyright, Designs and Patents Act 1988 (UK), s 5B.
} 
of the same content, and originality in the content itself was considered irrelevant by the Parliament of the United Kingdom. ${ }^{40}$ Thus, what is relevant for the purposes of copyright in "film" in the United Kingdom is that no copies are made of existing footage. ${ }^{41}$ The CDPA provides "copyright does not subsist in a film which is, or to the extent that it is, a copy taken from a previous film." 42

Conversely, in New Zealand, "film" is required to be "original" to qualify for copyright protection. ${ }^{43}$ It is unclear whether, for example, security camera footage would be considered sufficiently original to attain copyright protection in New Zealand. ${ }^{44}$ In the case of most virtual designs, however, it is unlikely that there would be the same doubt as to their originality because, unlike security camera footage, virtual designs rarely merely replicate real world material. There are, however, some exceptions to this rule. For example, in the United States case Meshwerks Inc v Toyota Motor Sales USA Inc ('Meshwerks'), ${ }^{45}$ the Court of Appeals held that show cars, which were replicated in digital form on a computer, were not sufficiently original for copyright, ${ }^{46}$ because the virtual design did nothing more than replicate material from the real world. ${ }^{47}$ This determination may have been different, however, had the issue arisen before the courts in New Zealand, as the United States has a different originality threshold to New Zealand. The leading decision is Feist Publications Inc v Rural Telephone Service Co Inc,${ }^{48}$ in which O’Connor J explained that copyright in the United States requires a “minimal creative spark". ${ }^{49}$

\footnotetext{
${ }^{40}$ See (23 February 1998) 493 GBPD HL 1057.

${ }^{41}$ Ibid.

${ }^{42}$ See Copyright, Designs and Patents Act 1988 (UK), s 5B(4).

${ }^{43}$ See Copyright Act 1994 (NZ), s 14.

${ }^{44}$ Frankel, above n 38, at 517.

${ }^{45}$ Meshwerks Inc v Toyota Motor Sales USA Inc 1258 F 3d 1265 (10th Cir 2008).

${ }^{46} \mathrm{Ibid}$, at [1270].

${ }^{47}$ Ibid, at [1265].

${ }^{48}$ Feist Publications Inc v Rural Telephone Service Co Inc 499 US 340 (1991).

${ }^{49}$ Ibid, at [1296].
} 
The difference in threshold is unlikely to be the determining factor in the case of most virtual designs, as such designs will usually comprise something more than mere replication of realworld material. Nevertheless, "film" does not seem a natural fit for these works.

Protection has been granted in the past to works that were not explicitly included in copyright law. In Meshwerks, the Court of Appeals, referring to Burrow-Giles Lithographic Co v Sarony (Burrow-Giles) ${ }^{50}$ noted the historic approach to protecting photographs. Although, historically, photographs were not considered copyright works because they were necessarily exact copies of a live scene or person, they were still able to be protected under copyright when the photograph revealed originality in the decisions of the photographer, by way of setting up the shot, adding lighting, and so on. ${ }^{51}$ Despite not being the case in that particular instance, as the virtual designs were merely digital replications of cars in a show room, the Court explained that virtual designs could be protected by copyright if there was evidence of original decisionmaking by the creator during the process of creation. ${ }^{52}$ Thus, effectively, in the absence of a specific category, copyright may be acquired, at least in the United States, when there is sufficient evidence of originality.

After the ruling in Burrow-Giles, photographs were eventually explicitly included as a category of work protected by copyright. ${ }^{53}$ Perhaps it is time again to introduce a new category. Academic 'S' stated:

I think we will have to introduce new categories. I do not look at someone who is creating a painting any different to someone who is creating a virtual animation. These are creative outputs. There is valuable creative work happening in both spaces.

\footnotetext{
${ }^{50}$ Burrow-Giles Lithographic Co v Sarony 111 US 53 (1884).

${ }^{51}$ Meshwerks Inc, above n 45, at [1264].

52 Ibid, at [1270].

${ }^{53}$ See Copyright Act of 1909 Pub L No 60-349 (US) § 535 Stat 1075 at 1078 (1909).
} 


\subsubsection{Protection qualification threshold}

The threshold in terms of "originality" is low in New Zealand. ${ }^{54}$ As noted above, the threshold in the United States is higher. Aside from requiring a "minimal creative spark", the Court in Meshwerks also took into account the intention of the work's creator. ${ }^{55}$ In New Zealand, however, Tipping $\mathrm{J}$ in Bonz Group (Pty) Ltd v Cooke doubted that the intention of the work's creator was relevant. ${ }^{56}$ Tipping J's doubts as to the relevance of intention reiterates the opinion of the New Zealand Copyright Committee in their 1959 report. ${ }^{57}$

Although the threshold in the United States for copyright protection of "fictional characters" is even higher than the threshold for the copyright works from which they originate ${ }^{58}$ it may not be so irrational for New Zealand courts to follow a similar approach with respect to virtual designs. Despite New Zealand's lower threshold with respect to "originality”, it is noteworthy that a higher overall threshold for the attainment of copyright protection is not alien to New Zealand courts. For example, something more, in addition to "originality", is required for a work to be protected in New Zealand as a "work of artistic craftsmanship".59

For a fictional character to acquire copyright protection in the United States independently of the work from which it originates, the character must be "distinctively delineated" 60 or "especially distinctive" in the "story being told". ${ }^{61}$ The same rationale might be applied to

\footnotetext{
${ }^{54}$ Work must originate from its author and must be the product of more than minimal skill and labour - see Henkel KgaA v Holdfast New Zealand Ltd [2007] 1 NZLR 577 (SC) at [37].

${ }_{55}$ Meshwerks Inc, above n 45, at [1268].

${ }^{56}$ See Bonz Group (Pty) Ltd v Cooke [1994] NZLR 216, at [223].

${ }^{57}$ Copyright Committee Report Presented to the House of Representatives (NZ, 1959) at 115.

${ }^{58}$ See Salinger v Colting 641 F Supp 2d 250 (SD NY 2009); and Rice v Fox Broad Co 330 F 3d 1170 (9th Cir 2003).

${ }^{59}$ What precisely is required for a work to be protected as a "work of artistic craftsmanship" is discussed in Section 6.1.4: Applicability of the "work of artistic craftsmanship" classification.

${ }^{60}$ Salinger $v$ Colting, above $\mathrm{n} 58$, at [254].

${ }^{61}$ Rice v Fox Broad Co, above n 58, at [1175].
} 
virtual characters. Just as fictional characters are inhabitants of literary and/or graphically depicted worlds, ${ }^{62}$ virtual characters are the inhabitants of digital, computer-generated worlds. Thus, for a virtual character to be protected by copyright independent of the computer program within which it exists, perhaps it must be shown to be "distinctively delineated" or "especially distinctive". In theory, the same rationale could apply to virtual objects. Inanimate objects have in the past acquired copyright protection independently of the work from which they originate.

One such example is the Batmobile. ${ }^{63}$

It is important to note, however, that the issue of independent copyright protection for characters or inanimate objects has not yet come before New Zealand courts. The notion of independent protection extending beyond the work may well raise concerns with regard to fixation.

\subsubsection{Fixation}

In order for copyright to subsist in a work, the work must be fixed in some material form. For some works, such as literature and film, the form of fixation is explicitly prescribed in the legislation, for example, literature must be recorded in "writing or otherwise", ${ }^{64}$ and film must be recorded "on any medium from which a moving image may by any means be produced". ${ }^{65}$ For other works, such as artistic works, there is no express reference as to the form of fixation. Fixation is nonetheless implicit because the legislative definitions refer to tangible materials. ${ }^{66}$

\footnotetext{
${ }^{62}$ See Walt Disney Prods v Air Pirates 581 F 2d 751 (9th Cir 1978), at [755].

${ }^{63}$ See DC Comics v Towle 802 F 3d 1012 (9th Cir 2015).

${ }^{64}$ Copyright Act 1994 (NZ), s 15(1).

${ }^{65}$ Copyright Act 1994 (NZ), s 2(1).

${ }^{66}$ Howe, St Ville and Chantrielle, above n 29, at [5-046]. For examples of references to tangible materials in definitions, see the definition of "graphic work" and "sculpture" in the Copyright Act 1994 (NZ), s 2(1).
} 
The primary reason for the fixation requirement is to restrict copyright protection to expressions as opposed to ideas. ${ }^{67}$

For example, the protection of a character independent of the work from which the character originates may be, on the one hand, perceived as protection of an idea. The same can be observed with respect to virtual designs. Academic ' $Q$ ' noted that "although ... many courts in China believe ... virtual designs ... are some kind of software ... they are ... seldom protected under the current copyright system". The main reason for this, academic 'Q' explained, is that "a work must be an expression".

On the other hand, Garnett et al explain that an idea is not an expression until the idea takes actual form. That expression is not, however, then limited to that one form. Once an expression has been fixed in one form, it can subsequently appear in other forms as well. ${ }^{68}$ The same fictional character may appear in different literary works and the same virtual character may appear in different computer programs. "Characters deform and move. So, the concept of shape lies in the more abstract, but the character does not change. It deforms but it is still the same character”, company ' $\mathrm{T}$ ' helpfully pointed out. Therefore, it makes sense for virtual designs to be protected independently of the software.

\subsubsection{Scope}

The scope of protection under copyright law for virtual designs is likely to be effectively the same as that provided for any other type of copyright work. Thus, infringement will be deemed

\footnotetext{
${ }^{67}$ Garnett, Davies and Harbottle, above n 36, at [3-107].

${ }^{68}$ Ibid, at [3-111].
} 
to have occurred if a restricted act is done in relation to the work, or a substantial part of it. ${ }^{69}$ However, it is likely going to prove very difficult to establish what is a "substantial part" of virtual designs that are of a multisensory nature, due to the complexity of elements involved in such works.

As noted above, virtual multisensory design may still be ahead of its time. Not all the necessary sense simulation technology is currently sufficiently developed to produce the effects intended. However, this is not a reason to adopt a wait-and-see approach and simply ignore the legal implications for such designs. It is beneficial to determine the scope of the protection ahead of time. $^{70}$

Elli Cho suggests that the complexity of multisensory designs means that a "general look and feel" test may be most appropriate. ${ }^{71}$

In the following section the discussion proceeds to consider whether virtual designs can be protected under the registered design system.

\subsubsection{Registering virtual designs}

The definition of "design" in the Designs Act 1953 (Designs Act) ${ }^{72}$ identifies several key elements that must be satisfied in order for a design to be registered. The extent to which each of these elements apply to virtual designs is discussed below.

\footnotetext{
${ }^{69}$ See Copyright Act 1994 (NZ), s 29.

${ }^{70}$ Cho, above $\mathrm{n} 8$, at 803 .

${ }^{71} \mathrm{Ibid}$, at 822. Suggestions and recommendations in terms of how a "general look and feel" test could be applied with respect to multisensory designs are provided in Section 6.1.3: Determining originality in cases of multisensory designs.

${ }^{72}$ See Designs Act 1953 (NZ), s 2(1).
} 


\subsubsection{Eye appeal}

One of the key elements is that the design must "appeal to" and be capable of being "judged solely by the eye". ${ }^{73}$ This element is unlikely to be a barrier for GUIs or CGI. The legislative reference to the "eye" first appeared in the United Kingdom in the Patents and Designs Act $1919,{ }^{74}$ but the concept that the "eye" was to be the judge in cases of design infringement had been developed previously in the common law. ${ }^{75}$ It was never, however, intended to require that a design must also entail artistic or aesthetic merit. ${ }^{76}$

\subsubsection{Function}

Another key element identified in the definition of design in the Designs Act is that a design must not be "dictated solely by ... function" ${ }^{77}$ Most virtual designs will have significant functional aspects to them. ${ }^{78}$ It is only designs that are dictated solely by function, however, that cannot be registered. ${ }^{79}$ The fundamental policy behind this exclusion is to limit the protection to specific designs and to prevent monopolies. ${ }^{80}$ Although most virtual designs will have the same basic functional features, there is usually significant design freedom with respect to their appearance. ${ }^{81}$ Thus, this element is not really a barrier for virtual designs.

\footnotetext{
${ }^{73}$ Designs Act 1953 (NZ), s 2(1).

${ }^{74}$ Howe, St Ville and Chantrielle, above n 29, at [3-049].

75 See, for example, Re Bayer's Design (1907) 24 RPC 65, at [77].

${ }^{76}$ Howe, St Ville and Chantrielle, above n 29, at [3-051].

77 Designs Act 1953 (NZ), s 2(1).

${ }^{78}$ Michael Risch "Functionality and Graphical User Interface Design Patents" (2013) 17 Stand Tech L Rev 53 at 55.

${ }^{79}$ Stigler, above n 2, at 240.

${ }^{80}$ Howe, St Ville and Chantrielle, above n 29, at [3-054].

${ }^{81}$ Stigler, above n 2, at 224.
} 


\subsubsection{Applied to an article}

Easily the most contentious element with respect to virtual designs is the requirement in the Designs Act that a design must be "applied to an article". ${ }^{82}$ Nevertheless, virtual designs have already been successfully registered in New Zealand. In Altoweb Incorporated's Application (Altoweb), ${ }^{83}$ the Intellectual Property Office of New Zealand (IPONZ) initially refused to register the design because it did not consider it as being "applied to an article". ${ }^{84}$ In their objection to the registration, IPONZ relied on Comshare Incorporated's Applications (Comshare), ${ }^{85}$ which was a decision of the Delegate of the Registrar of Designs in Australia. In Comshare, virtual designs were refused registration because they were not considered to be "applied to an article". Due to their transitory nature, they were not seen as capable of giving the computer screen a particular and specific appearance. ${ }^{86}$ Similarly, academic 'Q' pointed out that in China a design patent cannot be granted for "a design that is generated by a product, once it is powered on." The Guidelines for Patent Examination published by the State Intellectual Property Office of the People's Republic of China (SIPO) explicitly state: ${ }^{87}$

The following situations are ineligible for patent protection for design ... the pattern shown when the product is electrified, such as the pattern on the electronic watch dial, the pattern on the screen of the mobile phone, software interface, and so on.

\footnotetext{
${ }^{82}$ Designs Act 1953 (NZ), s 2(1).

${ }^{83}$ Altoweb Incorporated's Application [2000] IPONZ D1/2000.

${ }^{84}$ Ibid, at [3].

${ }^{85}$ Comshare Incorporated's Applications 23 IPR 145.

${ }^{86}$ Altoweb Incorporated's Application, above n 80, at [8].

${ }^{87}$ State Intellectual Property Office of the People's Republic of China Guidelines for Patent Examination (2010) at [7.4].
} 
However, academic 'Q' pointed out that despite the clear instructions to the contrary "some GUIs get protection in practice". This is because in China a design patent examination is not substantive, but a mere formality. ${ }^{88}$

In New Zealand, IPONZ's objection to the registration of a virtual design was dismissed at the Altoweb hearing before the Patent Office of New Zealand. ${ }^{89}$ Suwa Seikosha's Design Application (Suwa Seikosha) ${ }^{90}$ was referred to in support of the decision. Suwa Seikosha was a decision of the Registered Designs Appeal Tribunal in the United Kingdom, in which a transitory design was considered sufficient for registration. The fact that the display design of a digital watch could not be seen when it was disconnected from the watch's circuitry did not bar the design from registration. This was because the display could be seen when the watch was used for its intended purpose. ${ }^{91}$ In its decision, the Patent Office of New Zealand effectively adopted the same rationale. Comshare was disregarded because the Patent Office of New Zealand was of the opinion that the Australian decision did not take sufficient account of technological developments in its interpretation of "design". 92

Similarly, Jason Du Mont and Mark Janis suggest that new technologies such as virtual designs fit within the existing definition in the United States. Essentially, the same words are used in the definition of "design" provided in the design patent law of the United States as in the definition in the Designs Act. ${ }^{93}$ This is due to the fact that, when originally formulating their

\footnotetext{
${ }^{88}$ China IPR "Roadmap for Intellectual Property Protection in China" (2009) <www.china-iprhelpdesk.eu> at 7.

${ }^{89}$ Altoweb Incorporated's Application, above n 83, at [9].

${ }^{90}$ Suwa Seikosha's Design Application [1982] RPC 166.

${ }^{91}$ Altoweb Incorporated's Application, above n 83, at [7].

92 Ibid, at [8].

${ }^{93}$ See Patent Law 35 USC $§ 171$.
} 
design patent law, the United States borrowed substantially from the United Kingdom's Copyright of Designs Act $1839 .{ }^{94}$

In making their argument, Du Mont and Janis refer to Zahn's Application (re Zahn). ${ }^{95}$ In re Zahn, it was held that it was not necessary to depict how a design is embodied in an article in the design patent claim. ${ }^{96}$ Du Mont and Janis therefore argue that it is not a conceptually significant step to further infer from this that a design can be protected as long as it is associated with some article. ${ }^{97}$ It is difficult to agree that this is not a conceptually significant step. In the United States, a design can be depicted inside broken lines in a design patent claim. Broken lines are used to show that the design is not necessarily restricted to one article, but rather the same design may be applied to different articles. ${ }^{98}$ The design, however, still has to be "applied to an article". Du Mont and Janis" "associated" with an article suggestion is a much vaguer concept.

It is understandable why Du Mont and Janis try to interpret the definition as such. Certainly, such an interpretation is more accommodating to virtual designs. The decision in Altoweb was also correct in that it is important to take technological developments into consideration when interpreting the definition. In doing so, however, words cannot be given an unnatural meaning.

It is clear, as a legal advisor specialising in intellectual property (legal advisor ' $\mathrm{V}$ ') pointed out, that the Designs Act "does not contemplate the digital environment. The Act is 70 years old."

\footnotetext{
94 Jason Du Mont and Mark Janis "Virtual Designs" (2013) 17 Stan Tech L Rev 107 at 113.

95 Zahn's Application 617 F 2d 261 (CCPA 1980).

96 Ibid, at [268].

${ }^{97}$ Du Mont and Janis, above n 94, at 116.

${ }^{98}$ Compilation of the Replies to the Questionnaire on Graphical User Interface (GUI), Icon and Typeface/Type Font Designs SCT/36/2 REV 27 January 2017 (document prepared for the Standing Committee on the Law of Trademarks, Industrial Design and Geographical Indications) at 50.
} 


\subsubsection{Competition law and virtual designs}

Although the issue has not yet been determined by courts in New Zealand, in other jurisdictions, such as the United States, courts have recognised GUIs as protectable subject matter. ${ }^{99}$ However, courts in the United States are unlikely to find infringement in cases where the design of a GUI becomes a de facto standard in the industry. ${ }^{100}$ The main reason is that performance of other GUIs and other software may be dependent on compatibility with GUIs that have already proved popular. Thus, according to this reasoning, popular GUIs are effectively "building blocks", and thus must be freely accessible to all so as not to require others to reinvent the wheel. ${ }^{101}$

\subsection{D Printing}

Three dimensional (3D) printing is a technology that brings new meaning to the concept of copying. The technology has already ventured into the realms of what was once considered impossible, and yet it only continues to improve in capability. Although complex mechanical devices such as televisions or toasters are not yet being printed in one go, it is already possible to print physical objects, layer by layer, from digital files. ${ }^{102}$

"We use it every day for samples, checking and testing", a multinational company (company 'B') stated. "At this point they are actually making furniture. They can actually ... print a new standing desk", stated academic 'S', who also noted that:

\footnotetext{
${ }^{99}$ See, for example, Apple Inc v Samsung Electronics Co Ltd 678 F 3d 1314 (Fed Cir 2012).

100 Stigler, above n 2, at 227. See, for example, Real View LLC v 20-20 Techs Inc 683 F Supp 2d 147 (D Mass 2010).

${ }^{101}$ Stigler, above n 2, at 223.

${ }^{102}$ Lucas Osborn "Intellectual Property’s Digital Future" (2014) Social Science Research Network <ssrn.com> at 4.
} 
Recently, there was a team ... creating an open source motorcycle ... 3D printing ... all the pieces ... and building the entire thing from scratch. So it is just a matter of combining it all together.

As the technology advances, use of 3D printers will likely increase. With increased use, the following questions will become increasingly relevant. First, can designs that are created via a 3D printer qualify for protection? Second, how does the design owner protect against the propensity of the technology being utilised to infringe on their intellectual property rights? Both questions are addressed here, starting with the former.

\subsubsection{Copyrighting 3D-printed designs}

As noted in Chapter 3, the threshold for copyright protection in New Zealand is very low, ${ }^{103}$ so it is highly unlikely that the fact a design was printed via a 3D printer would bar it from acquiring copyright protection. The "work of artistic craftsmanship" classification, however, is more contentious, as it is harder for a work to qualify for copyright protection under this classification. ${ }^{104}$ This classification, as explained in Chapter 3, is more desirable for industrial design owners, as such works acquire a long period of protection, namely 25 years instead of 16. ${ }^{105}$ The interviewees who had an opinion on this issue were all agreed that 3D-printed designs could qualify as "works of artistic craftsmanship". "People often think this process is a really quick process, but it is not", noted academic ' $\mathrm{S}$ ', before elaborating:

\footnotetext{
${ }^{103}$ See discussion in Section 3.3.3.1: Originality requirement.

${ }^{104}$ See discussion in Section 3.3.3.2.1: Work of artistic craftsmanship; and in Section 6.1.4: Applicability of the "work of artistic craftsmanship" classification.

${ }^{105}$ See Copyright Act 1994 (NZ), s 75.
} 
Printing ... often takes a tremendous amount of time. It can take 3 or 4 days straight to shape, work, refine, etc. So it is just a different process of making, but no different to being a sculptor.

"If we design something on the computer and then print it, it's the same as sketching it on a piece of paper or moulding it in clay”, stated company ' $U$ '. The only difference, they explained, is that:

Now you can just hit 'ctrl z' and go back, whereas it probably took Michelangelo a thousand hours to sculpt David. It is just that if he made a mistake with David, then "oops, get me a new piece of marble."

Although there are clear benefits, such as the ability to instantaneously retract mistakes, the fact that the majority of the work is done on the computer does not make 3D printing an easy process. "You can sit at a computer and do anything, but unless you understand the materials that you are working with, you are wasting your time", a design-driven company (company ' $G$ ') stated. A fancy drawing on the computer does not equal a printable design. There may be "no way you can make it", company 'G' explained. "The junction may be impossible ... because ... you cannot make a junction that is going to hold that weight or you cannot bend this material like that, or whatever."

Artistic craftsmanship and 3D printing are thus not necessarily mutually exclusive concepts, because, as company ' $\mathrm{T}$ ' noted:

A 3D printer is a tool. It is nothing beyond that. A craftsman uses tools all the time and a 3D printer is no different to a paint brush or a table saw. What is important is personal involvement. The person would have to be involved in the whole process, from designing the object on the computer to 3D printing it themselves. You can be very skilled at 3D 
printing things, at least with the current state of 3D printers. So there is skill and arguably artistry in it.

A design academic (academic ' $D$ ') provided further insight on the type of personal involvement involved in well-printed 3D designs. They stated:

It involves quite a lot of technical skill, but also a lot of intuition and sensitivity. It takes ... time to tweak ... the speed, or the angle on the computer, to make the machine happy. The idea that a machine can be happy may seem like kind of a whacky thought, but it really does require something more. Really enjoying it is mainly where the craft is.

It is thus clear, at least in the present day, that a lot of work goes into well-printed 3D designs. This work could even arguably be described as "artistic craftsmanship". ${ }^{106}$ However, there may come a time, perhaps even very soon, when this will no longer be the case. "I think soon computers are going to be scripting it', noted academic 'D', before providing the following example:

I just finished working on a design and I would argue the computer did most of it. I really do not know if I can take credit for it. When people asked me about it, I felt like saying to them "go talk to that computer". It only took eight minutes. I used to spend years sculpting things and this thing honestly did it in eight minutes. That is when I started thinking, maybe I should not take credit, although legally I can.

This example indicates that today's technology may already be on the brink of true artificial intelligence, which, as academic ' $D$ ' pointed out, begs the question:

\footnotetext{
${ }^{106}$ What precisely constitutes a "work of artistic craftsmanship" is discussed in Section 6.1.4: Applicability of the "work of artistic craftsmanship" classification.
} 
Whether computers are becoming creative and if so, do we have to acknowledge them when we collaborate? I mean, if I use a program and it does $95 \%$ of the work, can I really claim that as mine?

Indeed, this is an interesting question addressing a fascinating and important topic, which is in itself worthy of independent research. For the time being, however, it is the human as opposed to the machine that is recognised as the creator of the work under copyright law. ${ }^{107}$ The same is true for registered designs. ${ }^{108}$

\subsubsection{Registering 3D-printed designs}

As long as the 3D-printed design is "new or original", ${ }^{109}$ there is nothing barring it from being registered under the Designs Act. Similarly, the fact that a design is 3D printed, as opposed to being manufactured by some other means, does not bar it from acquiring analogous protection in China. ${ }^{110}$

Therefore, the pressing issue is not whether 3D-printed designs can be legally protected, but rather whether $3 \mathrm{D}$ printing technology poses a threat to design owners and consequently competition in the market.

\footnotetext{
${ }^{107}$ See Copyright Act 1994 (NZ), s 5. Interestingly the issue of artificial intelligence challenging the traditional definition of "author" has been noted as a foreseeable issue in the current copyright law review - see Ministry of Business, Innovation \& Employment Issues Paper: Review of the Copyright Act 1994 (2018) at 32.

108 See Designs Act 1953 (NZ), s 6.

109 See Designs Act 1953 (NZ), s 5(1).

${ }^{110}$ See discussion in Section 4.2.2: Utility model patents; and Section 4.2.3: Design patents.
} 


\subsubsection{The impact of 3D printing on the rights of design owners and competition in the market}

Infringement on a mass scale is an impediment to competition in the market. If non-authorised copies of designs could be easily replicated in 3D with the use of a 3D printer, the economic incentive for developing "new or original" designs would be substantially reduced. The opinions of the interviewees who shared their thoughts on this subject, however, were divided. Several interviewees were fairly certain that the technology poses no real threat, at least in the near future, to intellectual property owners and competition in the market. Academic ' $\mathrm{C}$ ' commented:

Until it finds a niche that gives people something that is a necessity for your life, there is no real reason. You do not need new chairs every day. However, I do see a place for it with hobbyists and people in their garage making stuff, which is a normal creative thing.

3D printing of other people's designs by hobbyists and tinkerers is not, in the opinion of academic ' $\mathrm{C}$ ', something the law ought to try and regulate. "That was always going to happen. There is no way you should try to protect against that. Most of the time it is just a drawing anyway."

Often such drawings are provided for free intentionally by the original designers themselves. "A library of things you can download is already there and has been for a while. There is Thingiverse and other systems, where models are uploaded that people can print", explained academic ' $\mathrm{S}$ '. However, despite the availability of these libraries, they do not appear to be particularly popular. "The whole DIY phase faded away. It just could not catch fire. There was not enough there to really get people interested", observed academic 'S'. 
Thus, like academic ' $\mathrm{C}$ ', academic ' $\mathrm{S}$ ' was of the opinion that the technology poses no real threat, commenting:

We talked about this for years and years. Five or six years ago ... we could buy a $\$ 1,000$ 3D printer and we were like "oh everyone is going to have one in their home", but it never happened, it really never happened. We have discovered that when you own one, it only has so much use. You can only make so many coat hangers and those sorts of little trinkets, before you get bored of it.

Indeed, 3D printers have not to date become a common household product. This is likely because, despite being already able to print in several materials, the range of whole products that can really be printed without further human intervention is still fairly limited. "At the moment you can print plastic and metal parts ... but to ... integrate those parts with circuit boards and all the rest of it ... for a product ... such as a cellphone ... costs dollars", a design consultancy firm (company 'A') explained.

Thus, effectively, 3D printers are not currently popular because, in the words of a designer from company 'U', "people are too lazy". "I can make coffee at home”, they noted, "why do I buy it for $\$ 5$ from the coffee cart? Because I am lazy, that's why."

So, until 3D printers can print complicated products in one go, all components inclusive, they are unlikely to appeal to the general population. The question is, will this ever be possible? Academic ' $\mathrm{S}$ ' made the following statement in response to this question:

Can we make a machine that makes candy bars ... also make cars? Probably not. I think it is still very much a clear pipeline and so this idea of being able to print anything is interesting ... but it is still going to be subject to manual construction. 
"You are never going to print an optical cable, because the manufacturing in that is millions of dollars in research and development", company ' $U$ ' observed. At least in terms of the foreseeable future, company ' $\mathrm{A}$ ' was of a similar opinion, stating:

\begin{abstract}
Most mass-produced consumer products ... will not be ... 3D printed. You are looking at at least 10 years, and even then 3D printers are not going to replace traditional manufacturing entirely ... not ... for mass-produced products. They will, for low volume, customisable products, but the cost of the technology needs to go down a lot ... and the quality is never going to match injection moulding.
\end{abstract}

It is rather surprising that the above interviewees do not, even when taking into account foreseeable technological progression over the next decade, believe that complex products will be being printed without the need for further human intervention. Academic ' $S$ ' recognised that this was probably due to their "lack of vision". Indeed, it was probably only the more visionary of individuals who would have foreseen, 10 or certainly 20 years ago, that we would be walking around with little devices in our pockets containing what, in the past, would have been at least an entire room's worth of appliances and items, such as a telephone, television, computer, calculator, radio, as well as countless tapes, records, books, etc. Similarly, now it is probably only the more visionary of individuals who can imagine 3D printers, in the near future, printing highly complex products with limited to no human intervention required. One such visionary, legal advisor ' $\mathrm{L}$ ', commented:

At the moment $3 \mathrm{D}$ printing is not all that accessible, but it is going to be. It is going to get to the stage where buying a 3D printer will be like buying a TV or a fridge. The cost is going to come down a lot and therefore the ability for people to make things and then potentially infringe intellectual property is going to increase as well. 
The Chinese government has demonstrated faith and interest in the future of 3D printing technology. ${ }^{111}$ China is a global manufacturing powerhouse, and the government recognises the potential of $3 \mathrm{D}$ printing in the manufacturing industry. ${ }^{112}$ More and more products are proving to not only be produced at a lower cost, but also more efficiently, via 3D printing, than traditional manufacturing. ${ }^{113}$ For example, products that have been traditionally manufactured in parts and then soldered or welded together, are now often able to be printed as a single unit. ${ }^{114}$ The Chinese government sees such technological advantages as critical to staying ahead of the fierce global competition in the manufacturing industry. ${ }^{115}$

Since 2012, several government policies have been launched in China to promote and grow the industry. ${ }^{116}$ Media coverage has garnered significant interest from the public, ${ }^{117}$ and the availability of government subsidies, ${ }^{118}$ has led to rapid growth in research on $3 \mathrm{D}$ printing. ${ }^{119}$ The 3D printing market in China is estimated to reach 1 billion USD by 2021, with an average annual compound growth rate in the meantime, of $41.36 \% .{ }^{120}$ Government recognition, of the future importance of 3D printing, is also evident in the initiative of the Ministry of Education in China, to educate new generations about the technology. A programme has already been initiated to install 10,000 3D printers in primary and middle schools across the country. ${ }^{121}$

\footnotetext{
111 Wijaya $\mathrm{Ng}$ and others Opportunities and Challenges in China's 3D Printing Market (prepared by Ipsos Business Consulting 2015) at 7.

112 Ibid.

${ }^{113}$ Chang Tan and Chengcheng Li "Influence of 3D Printing on Industrial Design" (2017) 75 ACSR 279 at 279.

${ }^{114} \mathrm{Ng}$ and others, above $\mathrm{n} \mathrm{111,} \mathrm{at} 14$.

115 Ibid, at 7.

116 Ibid.

${ }^{117}$ Ibid.

118 Ibid, at 21.

119 Yuran Jin and Jiangnan Yu "Research on 3D Printing in China: A Review" (2016) 3 IJRSSET 1 at 4.

120 Tan and $\mathrm{Li}$, above $\mathrm{n} 113$, at 279.

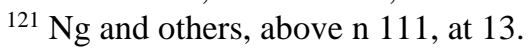


As a global manufacturing leader, it is likely that increased utilisation of $3 \mathrm{D}$ printing in China, will also influence increased utilisation of the technology in other countries, including New Zealand. Eventually, 3D printers will become common household products, and once this occurs, "industrial designs ... will probably be impacted ... just as significantly, as ... books, movies and recorded music ... were impacted ... by digital technology", stated legal advisor ' $\mathrm{V}$ '. Thus, at that point, the design industries, as company ' $\mathrm{T}$ ' pointed out, are likely to face "the same problems as what the music and film industries experienced."

The reason why 3D printing technology exposes designs to the same danger is because "it makes things a lot easier to copy", legal advisor ' $\mathrm{N}$ ' explained. The negative impact on some industries is more obvious than it is on others. For example, although academic ' $\mathrm{C}$ ' was not of the opinion that $3 \mathrm{D}$ printing is likely to pose a significant threat generally, they were nevertheless concerned about the potential impact on the antique automobile industry. They stated:

If people were to do things like scan antique vehicles and start 3D printing in metal, that could be a real problem for people who rely on those sorts of things. Someone may have said "I am the only person who owns this particular Harley-Davidson" or something like that. Then, next minute some guy says "well actually I have 5 in my garage, I just 3D printed them". So these people may be forced to wonder how to hide such objects.

Another great example of a negative repercussion of the technology was provided by a furniture design company (company 'H'). They stated:

One of the biggest fairs we go to every April is Salone del Mobile in Milan. So a new product can be out on stage showcased by a particular brand ... and ... within 48 hours somebody's already copied it and printed it out. I mean obviously 3D printing has a long way to go ... but that is the world we live in. 
This example clearly demonstrates that the negative impact on design owners' rights and competition in the market from 3D printing has already actualised in some instances. However, it remains "an area which we haven't really looked at legally yet”, noted company 'G'.

It is thus important to begin taking measures, or at least seriously planning ahead for the measures that will need to be taken, to mitigate the negative repercussions of $3 \mathrm{D}$ printing. It is risky to wait for the problem to more obviously manifest itself before taking protective measures, because, as academic ' $\mathrm{D}$ ' pointed out, the technological progression is likely 'to be so quick and ... so intense that ... we are not going to have time to argue about who did what."

Methods for mitigating the negative impact of 3D printing technology via alternative, non-legal protection measures, are identified in the next Chapter. That chapter also provides suggestions and recommendations for New Zealand policy and its law makers as to how to appropriately protect industrial designs in light of the other foreseeable advances in technology that were discussed in this chapter. 


\section{Suggestions and Recommendations in Light of Foreseeable Advances in Technology}

Drawing on the analysis from the preceding chapters, this chapter provides suggestions and recommendations for New Zealand policy- and law-makers as to how to appropriately protect New Zealand industrial designs in light of foreseeable advances in technology.

In terms of copyright it is recommended that in light of recent technological developments, particularly in virtual reality, and in anticipation of further advances in sensory technology, protection should be extended to creative expressions communicating to any and all senses so as to appropriately protect multisensory design. A new category of copyright protected works should be introduced for "multisensory works". To qualify under this category it is important that such works are original. Taking into account the creative scope of existing technology, the importance of discerning originality in works communicating to senses other than auditory or visual is stressed. It is suggested that a "general look and feel" test should be utilised with respect to multisensory designs so as to extend protection to the creative expression in such works as opposed to the underlying idea. Some multisensory designs may qualify as "work of artistic craftsmanship". It is suggested that the application of additional skill over and above the skill applied in ordinary craftsmanship is required for qualification under this copyright classification. Skill however, is impossible to quantify precisely and so it is suggested that the inclusion of examples in legislation could be useful to shed some light on the ambiguous concept.

In terms of the registered design system it is suggested that the definition of design should be reconceptualised. It is recommended that reference to "the eye" should be removed from the 
definition so as to appropriately accommodate multisensory designs. Similarly, to extend protection to virtual design, the words "or perceivable in a product" should follow the words "applied to an article".

To ensure creativity in developing fields, such as virtual reality is not stifled, it is important that the threshold for registration appropriately reflects the balance between the interests of the design owner on the one hand, and the greater public on the other. The existing threshold of "new or original" is often interpreted inconsistently with case law at the point of registration. The threshold is meant to be significantly higher than that of copyright. It is suggested that the words "or original" be substituted with "and distinctive" to make this more obvious.

To really ensure that the threshold is applied appropriately, it is necessary for a substantive examination to be conducted prior to registration. The high cost and delays associated with a substantive examination can be mitigated by improving the design register, in particular the search tool that is available to the general public. An effective search tool should significantly reduce the amount of time required to examine prior designs. More importantly, it should provide design owners with a more accurate indication at an early stage of design development as to whether or not they should proceed with registration.

Registration outside New Zealand may potentially be simplified, if New Zealand were to accede to the Hague Agreement. ${ }^{1}$ However, until China (New Zealand's main outsourcing destination for manufacture) becomes a member, the benefits of accession do not appear to outweigh the costs.

\footnotetext{
${ }^{1}$ See Hague Agreement Concerning the International Deposit of Industrial Designs (6 November 1925, entered into force 1 June 1928, as revised at London 1934, The Hague 1960, Monaco 1961, Stockholm 1967, amended 28 September 1979, and revised in Geneva 1999).
} 
It is also suggested that the terms of protection under both the copyright and registered design systems may need to be reduced for emerging designs from developing fields such as virtual reality so as not to unduly impede the rapid pace of creativity and innovation in these fields. However, as a signatory to the Berne Convention, ${ }^{2}$ and TRIPS, ${ }^{3}$ New Zealand is only able to extend, but cannot not reduce the terms of protection. Thus, the members of these international agreements need to revisit the relevant provisions, or alternatively a new superseding international agreement may need to be drafted, specifically with respect to designs in the information technology industry and related fields.

It is also suggested that the term of protection may need to be tailored to more appropriately protect designs in other industries as well. Specific recommendations as to appropriate protection terms however, should be informed by further research that takes account of industry specific interests and considerations. Similarly, further research would be beneficial for identifying industries where legally permitted exceptions to protection may be required. The motor vehicle industry was identified in this study as an industry where a "spare parts exception" should be introduced so as to provide car owners with access to more affordable replacement parts.

All of the above suggestions and recommendations are elaborated upon below. Their implementation (subject to further research where indicated), should improve the protection for New Zealand designs in light of foreseeable advances in technology. However, due to the New Zealand Government's pattern of adopting a reactive approach, it is likely that necessary amendments to law will not be timely, even when there are foreseeable negative ramifications

\footnotetext{
${ }^{2}$ See The Berne Convention for the Protection of Literary and Artistic Works (9 November 1886, as revised at Paris 1986, Berlin 1908, Rome 1928, Brussels 1948, Stockholm 1967, Paris 1971, amended 28 September 1979). ${ }^{3}$ See Agreement on Trade-Related Aspects of Intellectual Property Rights (15 April 1994, entered into force 1 January 1995).
} 
on industrial design from advancement in technology such as 3D printing. For this reason, recommendations are also provided below for how New Zealand industrial design owners can utilise non-legal strategies to mitigate this foreseeable risk to their intellectual property rights.

\subsection{Suggestions and Recommendations with Respect to Copyright}

The issues relevant to industrial designs in copyright law include the extent of protection provided for expressions other than visual or auditory and for virtual designs, determination of originality in cases of multisensory designs, and the applicability of the "work of artistic craftsmanship" classification.

\subsubsection{Protection of non-visual/auditory expression}

Industrial designs can be protected in New Zealand under copyright law and/or registered designs. ${ }^{4}$ Although industrial designers have traditionally focused primarily on the visual sense, the importance of more holistic design is becoming increasingly apparent. ${ }^{5}$ This raises the question, can the non-visual aspects of design comprise original expression (for the purposes of copyright protection)?

6.1.1.1 Can non-visual/auditory aspects of industrial design comprise original expression?

Although original works were historically capable of appealing to other senses by, for example, description in literature or depiction in film, ${ }^{6}$ for the large part, creators did not have the

\footnotetext{
${ }^{4}$ New Zealand copyright and registered design protections are discussed in Chapter 3.

${ }^{5}$ See discussion in Section 2.2.1: Aesthetics.

${ }^{6}$ See discussion in Section 2.2.1.1: Western aesthetic theory.
} 
technology to enable them to express their works to the other senses. Modern technology has changed this situation.

Designers usually refer to holistic design as interactive design. Joep Frens explains that, rather than just focusing on visual aesthetics, interactive design is also very much focused on the aesthetics of use. ${ }^{7}$ Aesthetics of use is evident, or rather becomes apparent, after the user has physically interacted with the industrial design. Aesthetics of use is not about how a product performs its utilitarian function, but rather about how using the product makes the user feel. ${ }^{8}$

Aesthetics of use was addressed in the United States in OddzOn Products Inc v Oman. ${ }^{9}$ In this case, subsistence of copyright in the KOOSH ball was at issue. After the Register of Copyrights denied its registration, the designer filed suit arguing that it should be protected by copyright due to its tactile originality. Although initially the Register determined that tactility was not capable of copyright protection, on appeal to the DC circuit the Register abandoned this claim in favour of the separation argument, which was, in the end, the basis for the Court's decision that the KOOSH ball did not have copyright. The tactility of the KOOSH ball was held to be inseparable from its function. ${ }^{10}$ The function of its light, elastic makeup is amenability to grip, making it a good tool for teaching small children developing their motor skills how to catch. Although the KOOSH ball may have also had a tactile purpose, it was the same material that performed this function that also made it pleasant to the touch. ${ }^{11}$ This raises the question of whether it is possible to create tactile expression, or any other sensory expression outside of visual or auditory, that is not also a functional feature?

\footnotetext{
${ }^{7}$ Joep Frens Designing for Rich Interaction: Integrating Form, Interaction, and Function (JFS, Eindhoven, 2006) at 142 .

${ }^{8}$ Ibid.

${ }^{9}$ OddzOn Products Inc v Oman 924 F 2d 346 (DC Cir 1991), at [1270].

${ }^{10}$ Ibid, at [349].

${ }^{11}$ Christopher Buccafusco "Making Sense of Intellectual Property Law” (2012) 97 Cornell L Rev 501 at 520.
} 
There are several other examples of functional design features that also have expressive characteristics. A design academic (academic 'C') suggested the following example:

Imagine driving on the road and you have your foot on the accelerator. Your foot, your little toe is maintaining your car at 50 or 60 miles an hour for really long periods of time. It is very imperceptible movement, but it provides sensory feedback.

An even more basic example is a button. Frens explains that a button, at least a well-designed button, expresses that it should be pushed, without needing to have written on it "push here". Rather, this direction can be expressed in the way the button feels when interacted with. The instruction is expressed through the texture of its surface, its weight and its resistance to pressure. $^{12}$

These examples are clearly similar to the KOOSH ball, in the sense that their expressive characteristics are intertwined with function. Frens' explanation of how features that are neither visual nor auditory can express instructions for use, illustrates that such physically inseparable features are, at least conceptually, distinguishable.

The next logical question is, since expression that is neither visual nor auditory is inevitably intertwined with functional design features, does this mean such expression cannot be protected under copyright?

${ }^{12}$ Frens, above $\mathrm{n} 7$, at 51. 
6.1.1.2 Is non-visual/auditory expression protected under copyright?

Although copyright in the United States requires the artistic feature of a work to be separable from its function, ${ }^{13}$ it need only be conceptually separable. ${ }^{14}$ In Star Athletica LLC $v$ Varsity Brands Inc, the United States Supreme Court held that as long as the artistic feature, which is imagined apart from the useful article, would qualify as an original work, it can be copyright protected. ${ }^{15}$ Physical separation is not necessary. ${ }^{16}$ Thus, the artistic feature of a useful article is not barred from protection if the separation from the useful article would render the remaining article functionally useless, or even just less useful. ${ }^{17}$ Moreover, the feature of the article which can be imagined as a separate artistic work, need not be entirely free from utility. ${ }^{18}$ What is important, is that the feature imagined to be separate, can qualify as an original work. ${ }^{19}$

In New Zealand, there is no separation requirement at all for copyright protection. Just because New Zealand does not have the separation requirement, however, does not automatically mean the KOOSH ball would have received copyright protection in New Zealand. Although Frens' explanation illustrates that functional features can also be expressive, these examples of expression are unlikely to be sufficiently original to qualify as copyright protected works. The non-visual expression in these examples is merely directing one to experience the function. Although the originality threshold for copyright is low, this type of expression seems more analogous to expressions comprising raw facts or data. Such expressions are insufficiently original, as there is no input from the work's creator other than perhaps minimal skill and labour

\footnotetext{
${ }^{13}$ See Copyright Law 17 USC $\S 101$.

${ }^{14}$ See Star Athletica LLC v Varsity Brands Inc 137 (S Ct 2017) 1002, at [1011].

${ }^{15}$ Ibid, at [1008].

${ }^{16} \mathrm{Ibid}$, at [1011].

${ }^{17}$ Ibid, at [1010].

${ }^{18}$ Ibid.

${ }^{19}$ Ibid, at [1008].
} 
in reproducing the raw facts or data. ${ }^{20}$ Similarly, non-visual expression that merely directs one to the function of a product may not be enough for copyright.

In New Zealand as well as in several other commonwealth jurisdictions, courts have held compilations of factual data to be the products of sufficient skill and labour for the purposes of copyright. ${ }^{21}$ However, Elizabeth Judge and Daniel Gervais point out that courts in several jurisdictions, including New Zealand, have taken further consideration of certain works, such as factual data compilations and derivative works, so as to ensure such works reflect sufficient contribution by the author. ${ }^{22}$ For example, in explaining how the originality standard was satisfied in a compilation of financial survey data, the Court of Appeal in University of Waikato $v$ Benchmarking Services Ltd stressed that there was a "number of unusual or unique features which clearly result from the expenditure of significant creative effort and skill." 23 Thus, in this instance, Judge and Gervais explain, creative effort as well as the unusual or unique features were used as measures of the originality standard of sufficient skill and labour. ${ }^{24}$

It is likely that work comprising expression other than visual or auditory would be another type of work in which the author's contribution would be particularly difficult to discern. This is because the scope of such expression, or at least existing means for conceptualising such expression, is significantly more limited than the scope of visual or auditory expression. Thus, it would likely be necessary to conduct a more in-depth inquiry to discern whether expression outside of visual or auditory is sufficiently original.

\footnotetext{
${ }^{20}$ To be original for copyright purposes the work must originate from its author and must be the product of more than minimal skill and labour - see Henkel KgaA v Holdfast New Zealand Ltd [2006] 1 NZSC 102, at [37].

${ }^{21}$ Elizabeth Judge and Daniel Gervais "Of Silos and Constellations: Comparing Notions of Originality in Copyright Law” (2009) 27 Cardozo Arts \& Ent L J 375 at 395.

${ }^{22}$ Ibid.

${ }^{23}$ University of Waikato v Benchmarking Services Ltd (2004) 8 NZBLC 101 (CA), at [42].

${ }^{24}$ Judge and Gervais, above n 21, at 398.
} 
The issue has never arisen before the courts in New Zealand. So, the discussion here is a pragmatic attempt to illustrate how originality in expression other than visual or auditory can be discerned.

Although it may not always be prima facie evident, expression that is neither visual nor auditory can in fact reflect more than product function. A multinational company (company 'E') explained that, rather than reflecting product function, their non-visual expression reflects the quality of their products. They stated:

We talk about honesty to materials. A lot of ... products ... use plastic knobs that are chrome plated. On most of our products ... we have ... solid stainless steel knobs. The reason is durability and ... the other aspect of it is that when you touch a solid stainless steel knob, it feels cold, and subconsciously you actually know it is a solid material. Whereas ... plastic knobs that are chrome plated ... do not have that solidity, mass or ... cold feel. So therefore you kind of know that it is fake. How our products are subconsciously perceived is very important to us and we put a lot of effort into that. Each switch has a different pressure and feel ... and there is a perception of precision created by that.

In addition to reflecting product function and quality, Frens also suggests that non-visual aspects of design can communicate to a person on an emotional level. ${ }^{25}$ The example Frens provides is a frequency knob on a vintage radio. According to Frens, the feel of the knob between the fingers, the friction, the beeping and ticking sounds corresponding with the rotation speed, as well as the feeling of the transponder perfectly aligning with a radio frequency, equals a pleasurable aesthetic experience. ${ }^{26}$

\footnotetext{
${ }^{25}$ Frens, above $\mathrm{n} 7$, at 54 .

${ }^{26}$ Ibid, at 57.
} 
Although this example illustrates how the non-visual aspects of design can invoke aesthetic feelings in the user of the product, it seems too subjective. A different person may turn the same knob thousands, if not millions, of times and not once care, or give it enough thought, to appreciate the experience and get some pleasure out of it. Moreover, it must be the designer's expression that is appreciated. This example seems more attributable to the user's experience rather than the designer's expression. For copyright to subsist, there probably needs to be a clearer connection between the two. The designer's expression should direct the user's experience and the directed experience must be about more than just appreciation for the product's function. Of course, all experiences are necessarily subjective, but all subjective experiences are nevertheless governed by a number of universal principles - that is, we have a biological disposition to symmetry, there are favourable degrees of contrast, and so on. ${ }^{27}$ Thus, even if an exact experience cannot be directed, a good design should nonetheless be able to direct an approximate experience. Moreover, it also important to take into consideration the fact that appeal is usually targeted. For example, a particular design may be targeted at a very particular class of consumer. As such, it is to be expected that the design may not appeal to the masses. However, the designer may well have achieved the desired appeal if they successfully direct the intended (albeit approximate) experience within a substantial portion of their target audience. The question remains, however, is it possible to direct an approximate experience via the non-visual aspects of design?

A similar example to the above tuning knob but with additional characteristics may be helpful here to illustrate how this could be done. Consider a tuning knob that regulates the bass level of an amp. Instead of a regular knob, this one is made of a heavier and more solid metal. Moreover, the heavier metal is coupled with much more substantial spring resistance than a

\footnotetext{
${ }^{27}$ See discussion in Section 2.2.1: Aesthetics.
} 
regular tuning knob. This particular knob was designed by a design academic who also works as an industrial designer (academic 'D'). Their intention was to give the user the feeling that they are adjusting something dense and heavy, namely bass, thus invoking the feeling in the user that "they are moving a significant thing, from a serious piece of equipment."

Indeed, the knob in academic 'D's' example does seem like it could direct an approximate experience, and thus perhaps this particular expression is worthy of copyright protection. It is important to remember, however, that any expression, even if it does direct more than just an appreciation for a product's function, must not be too broad. For example, tactile expression that successfully directs a pleasurable experience in the majority of users is probably not worthy of copyright protection. Pleasure is a very broad feeling and is thus more analogous to an idea rather than expression. Although the originality threshold for copyright is low, due to the limited scope of expression outside the visual and auditory senses, it seems appropriate to inquire further into the nature of the expression, so as to ensure sufficient original contribution by the author.

The design in academic 'D's' example is a significantly more directed aesthetic experience than Frens' tuning knob example, and thus is more likely to be an original expression. Perhaps an example that more clearly illustrates expression in aspects of design that are neither visual nor auditory is Alessi's "Mary Biscuit” cookie container, designed by Stefano Giovannoni. To evoke positive feelings and emotions associated with family and the comfort of domestic life, the "Mary Biscuit" design communicates to multiple senses simultaneously to produce the experience. The typical container used for keeping cookies is a plain solid metal box with sharp edges, which is rather dull and perhaps even harsh in appearance and feel, hardly reflective of the goodness inside. Moreover, the metal material makes an unpleasant sound when dropped 
or even when hurriedly placed on most surfaces. In contrast, the "Mary Biscuit's" rounded, cushion-like design ensures minimal noise and also makes it pleasant to hold. Its soft texture invites tactile interaction and is meant to inspire emotional sensations relatable to how one may feel when holding or cuddling a dearly loved soft toy. To further inspire the warm, comfortable experience, the "Mary Biscuit" design is impregnated with a vanilla essence (a common ingredient in cookies) for the purpose of utilising the meaningful memory-triggering characteristic of smell, ${ }^{28}$ thus cementing the customer's experience with the product by association with one's own fond memories. Perhaps, for example, it would trigger happy memories of indulging in delicious cookies as a child, at Grandma's house, on lazy Sunday afternoons.

The "Mary Biscuit" example illustrates that original expression can indeed be communicated via senses other than auditory or visual, but the question remains, can expression be protected under existing copyright law, and if not, should it be?

Although it was not the specific issue for determination, the Netherlands Supreme Court in Lancôme Parfums $v$ Kecofa BV (Lancôme Parfums) observed that the smell of perfume is capable of meeting the originality threshold for copyright protection if it is the product of sufficient creative input. The Supreme Court explained that a scent expression is not simply the way something smells, rather the scent expression adds its own unique twist to the smell. ${ }^{29}$ Although this direction is not particularly helpful for determining original scent expression, the preceding decision in the same case (at the Supreme Court Public Prosecutor's Office), drew a

\footnotetext{
${ }^{28}$ Hendrik Schifferstein and Charles Spence "Multisensory Product Experience" in Hendrik Schifferstein and Paul Hekker (eds) Product Experience (Elsevier Ltd, Amsterdam, 2008) 133 at 149.

${ }^{29}$ Case C04/327HR Lancôme Parfums v Kecofa BV (NL HR 16 June 2006), at [3.2]. Conversely, just three days earlier, the Supreme Court in France, held that a perfume was merely the implementation of technical knowledge and therefore does not constitute original expression that is subject to copyright - see Bsiri-Barbir v Haarmann \& Reimer Cour de Cassation [2006] 28 ECDR 380.
} 
helpful analogy in distinguishing the recipe for a scent, which is protected by patent, from a scent expression. The example the court used was a book. The expression that is protected by copyright is not the physical pages of the book or even the printed words, but rather the expression that the words printed on the paper convey when read. Similarly, scent is not the recipe or even the physical substance producing the smell, but rather the expression is the smell itself. $^{30}$

More recently, in Levola Hengola BV v Smilde Foods BV (Levola Hengola), ${ }^{31}$ the Court of Justice of the European Union (CJEU) issued a ruling on whether taste could be copyright protected..$^{32}$ The CJEU held that the taste of a food product was not capable of being copyright protected because taste expression could not be "pinned down with precision and objectivity". ${ }^{33}$ The CJEU reasoned that taste sensations are too subjective depending on: ${ }^{34}$ ... factors particular to the person in tasting the product concerned, such as age, food preferences and consumption habits, as well as on the environment, or context in which the product is consumed.

Eugénie Coche points out the CJEU's observation regarding the subjectivity of the experience is applicable to essentially any work of art. ${ }^{35}$ What perhaps does distinguish taste, at least for the time being, from works for the auditory or visual senses, is the inability to pinpoint taste expression with sufficient precision. ${ }^{36}$ The CJEU's decision was however, clearly made in light of current technological and scientific progress. The CJEU stated: ${ }^{37}$

\footnotetext{
${ }^{30}$ Ibid, at [5.20].

${ }^{31}$ Case C-310/17 Levola Hengola BV v Smilde Foods BV (Levola Hengola) ECLI:EU:C:2018:899.

${ }^{32}$ In this case the subject matter at issue was the taste of spreadable cheese.

${ }^{33}$ Levola Hengola BV v Smilde Foods BV, above n 29, at [42].

${ }^{34}$ Ibid.

${ }^{35}$ Eugénie Coche "Heks'nkass or the "fiftyshades of taste" explained by the CJEU through EU copyright law" (2019) 41 EIPR 173 at 178.

${ }^{36}$ Ibid, at 174 .

${ }^{37}$ Levola Hengola BV v Smilde Foods BV, above n 33, at [43].
} 
$\ldots$ it is not possible in the current state of scientific development to achieve by technical means a precise and objective identification of the taste of a food product which enables it to be distinguished from the taste of other products of the same kind (emphasis added).

Even if one is of the view that it is already possible, at least in some cases, to discern or pin down original taste expression with precision and objectivity, it must be observed that in New Zealand there is another potential barricade for non-visual or auditory works in attaining copyright protection. In New Zealand, expression must not only be original, but must fall within a category of work listed in the Copyright Act 1994 (Copyright Act). ${ }^{38}$ It is likely that a lot of expression that is neither visual nor auditory will not (at least naturally) fall within any of the copyright categories. The reason being, as a legal practitioner specialising in intellectual property (legal practitioner 'I') pointed out, "that the law was written at a time when these things did not exist."

Thus, in order to extend the scope of protection for expression that is neither visual nor auditory, new categories would likely need to be introduced into the Copyright Act. Alternatively, categories could be removed from the statute altogether. Several European countries, including France and the Netherlands, do not limit copyright protection to specific categories of work, but, rather, copyright can subsist in any original work of the mind. ${ }^{39}$ Introducing new categories is a more reasonable approach for New Zealand to take and would certainly be less radical, considering the long history of precedent, regarding copyright categories, in the common law.

\footnotetext{
${ }^{38}$ See Copyright Act 1994 (NZ), s 14.

${ }^{39}$ Craig Mende and Belinda Isaac "When Copyright and Trademark Rights Overlap" in Neil Wilkof and Shamnad Basheer (eds) Overlapping Intellectual Property Rights (Oxford University Press, Oxford, 2012) 137 at 151.
} 
The following section addresses the importance of extending the scope of copyright protection for expression that is neither visual nor auditory.

\subsubsection{Should non-visual/auditory expression be protected?}

Although there are some impressive multisensory designs, such as the "Mary Biscuit", there are not at present many examples of such work. Frens explains that there are few examples of such designs because the work requires additional skills that many industrial designers do not possess. ${ }^{40}$ Moreover, for the large part, the technology that has been generally available to industrial designers does not provide sufficient capacity for the development of serious multisensory design. ${ }^{41}$ The latter reason is obviously the more significant impediment. However, Frens notes that the current rate of technological development, particularly in the information technology sector, promises to significantly expand the scope of possibilities for design creativity. This observation is on par with the forecast of a company in the virtual reality field (company ' $R$ '):

The way we see the future is everyone wearing augmented reality glasses, and probably gloves or haptic sensory chips, if people are set on having haptic feedback, so that you could feel virtual objects with your fingers. So people will no longer be carrying phones around.

Although it may not be the case now, it is evident that the time when catering to multiple senses will become a crucial element of design is fast approaching. ${ }^{42}$ "I know it will be an oncoming issue as virtual reality takes off', legal practitioner 'I' commented.

\footnotetext{
${ }^{40}$ Frens, above $\mathrm{n} 7$, at 186.

${ }^{41}$ Ibid, at 103 .

${ }^{42}$ Ibid, at 186.
} 
In anticipation of a significant rise in multisensory design, it is suggested that copyright law should be extended to design expression for all senses and not merely auditory or visual. This can be achieved by removing categories of copyright protected works altogether and by simply extending protection to all original expression. Introducing new categories of protected works however, is a more reasonable approach for New Zealand due to the long history of precedent regarding copyright categories in the common law. The introduction of a new copyright category for "multisensory works" is thus recommended.

\subsubsection{Protecting virtual designs}

Growth in demand for virtual reality devices, such as the Oculus Rift or the HTC Vive, ${ }^{43}$ is dependent on advances in virtual multisensory design.

It is certainly possible to envision how a virtual realty design can comprise multisensory expression. In fact, what exactly constitutes a multisensory expression is perhaps easier to explain with reference to a virtual reality design example. Imagine that you have put on the necessary headset, which includes a scent expeller, and now find yourself standing before an enormous Christmas tree. The tree is decorated and covered in flashing lights. It looks remarkably real and it even smells exactly how a fresh-cut pine Christmas tree should smell.

The question is, is this multisensory virtual design a sufficiently original expression? Probably not, as it arguably only replicates raw facts (real-world data) - that is, pine trees smell like pine. Moreover, a decorated pine-smelling Christmas tree is so common and obvious that it seems

\footnotetext{
${ }^{43}$ For more information on these devices - see Section 5.1: Virtual Designs.
} 
more analogous to a general idea than an original expression. Of course, the particular decorations and the pattern in which they are placed on the tree may perhaps be original, but for the sake of the example, this possibility will be ignored. Suppose, for the sake of argument, the decorations are not original. Now, consider that the image remains the same, but the scent is replaced with the smell of fish and chips and the ocean. The combination of the Christmas tree image and this smell may, if the creator of the virtual design succeeded in directing the experience, invoke the feeling within you of a Kiwi-style Christmas on the beach. The likelihood of success would probably be substantially increased if you also had headphones on, through which you could hear the sound of waves breaking, seagulls squawking and children playing. Perhaps, in addition, the headpiece could also expel heat onto your cheeks to make it feel like a hot summer's day. The combination of these things should be sufficient to approximate the Kiwi-style Christmas experience, and therefore will likely be an original multisensory expression.

Copyright protection for this multisensory expression would not mean somebody else would be prohibited from using a Christmas tree in their multisensory virtual design, or including the sound of waves breaking, or expelling heat onto the cheeks, but, rather, they could not copy these things in their particular combination - that is, this particular expression or a substantial part of it. For example, if someone were to use the same sounds and scent, but replace the tree with another popular Christmas ornament, such as the wreath or the mistletoe, this would likely be copyright infringement. Conversely, there would probably be no infringement if the same generic Christmas tree was utilised along with snoring and drunken laughter sounds, and a scent combining the smell of cologne, cigars and whisky, to direct one to think of their grandfather, favourite fun uncle, or someone along those lines, at Christmas time. Instead, this too would probably constitute an original multisensory expression. 
As evident from the above example, expression outside of the visual and auditory senses can be meaningful and original. Industrial design is constantly evolving. It is no longer merely about form following function. ${ }^{44}$ It is already often about much more than that and with the capabilities provided by advancing technology, design focus continues to shift toward holistic product experience. ${ }^{45}$ Based on the current rate of progression in the virtual reality field, there is likely to be a continued increase of creative as well as fiscal investment in multisensory expression. ${ }^{46}$ Increased investment in multisensory expression will likely lead to an increase in intellectual property claims in this area. ${ }^{47}$ In anticipation of this, the above discussion preemptively suggests how originality in such expression can be determined.

The question of whether virtual designs should be legally protected by copyright has not yet been determined by New Zealand courts. Courts in other jurisdictions, such as the United States, have held virtual designs to be protectable subject matter. ${ }^{48}$ They have been reluctant to find infringement, however, where virtual designs, such as graphic user interfaces (GUIs), are considered to have become a de facto standard in the industry. ${ }^{49}$

“That's a good thing isn't it?" a company in the virtual reality field (company 'U') observed, before elaborating:

The reason things are popular is because they work. If someone brings out a car with levers and a handle, no one is going to buy it, because we are all used to ... a steering wheel and pedals.

\footnotetext{
${ }^{44}$ Gerald Cupchik and Michelle Hilscher "Holistic Perspectives on the Design of Experience" in Hendrik Schifferstein and Paul Hekker (eds) Product Experience (Elsevier Ltd, Amsterdam, 2008) 241 at 241.

${ }^{45}$ Schifferstein and Spence, above n 28, at 149.

46 See Gareth May "Fifth Sense: The next stage of VR is total sensory immersion: How will VR expand from audio and visual to incorporate the other senses?" (2017) Wareable <www.wareable.com>.

${ }^{47}$ Rana Ansari and others Augmented and virtual reality: emerging legal implications of the "final platform" (white paper prepared by Reed Smith LLP 2017) at 1.

${ }^{48}$ See, for example, Apple Inc v Samsung Electronics Co Ltd 678 F 3d 1314 (Fed Cir 2012).

${ }^{49}$ See discussion in Section 5.1.6: Competition law and virtual designs.
} 
Prima facie the rationale that things that have become standard in the industry should be free for all to utilise may seem reasonable. In fact, it probably is reasonable, with respect to more traditional industries in which systems and interfaces that prove efficient become standard over time. It is not, however, reasonable with respect to the information technology industry, in which something can become standard extremely quickly. The term "viral" is often used to describe something that gains popularity in cyberspace, virtually overnight. The fact the word has become a part of common language is testament to the frequency of the phenomenon.

Despite the speed of developments in cyberspace, a design academic specialising in virtual reality (academic ' $\mathrm{S}$ ') was nevertheless of the opinion that:

When it comes to protecting things like interfaces, I see that as a chilling effect on the rest of development. So, for example, Microsoft has designed an interface called "bloom". So when you hold out your hand in front of you and then open your hand, it opens a menu. Now, that could become standard, or it could be something that Microsoft just says "well we own it, we own this movement", and that starts to slide into a very dangerous place.

The dangerous place Academic ' $\mathrm{S}$ ' is referring to, is a legal environment which provides for the protection of expression that is too general. Thus a system which allows one to take (by obtaining exclusive rights in such general concepts) ideas from the public domain. This is of course dangerous as free access to these ideas should be available to all so as to allow others to develop their own works. ${ }^{50}$

\footnotetext{
${ }^{50}$ For further discussion on the dangers of expanding the scope of protection to ideas see Section 3.1.3: Expanding the scope of protection for industrial designs.
} 
Expression which is too general (i.e. synonymous with an idea) cannot be protected by copyright or as a registered design. ${ }^{51}$ The "opening of the hand" gesture which Academic ' $\mathrm{S}$ ' describes however, is not necessarily an expression that is too general. It is important not to dissociate the physical gesture from the corresponding virtual menu. When the gesture is considered in context, it may well constitute sufficiently original expression.

It is another thing to observe that such an expression may prove very useful and thus become a standard interface in the industry. Just as the subject of a standard essential patent needs to be licenced on a fair, reasonable and non-discriminatory basis, ${ }^{52}$ an interface that become so standard so as to effectively become a building block in the industry, may need to be subject to similar compulsory licencing, so as not to stifle further development.

However simply not protecting original expression because it has become so popular so as to effectively become standard in the industry, is arguably anticompetitive, because it allows dominant players in the industry to simply copy revolutionary GUIs developed by small companies into their own systems. ${ }^{53}$ As their systems are already utilised by millions of people, it is possible for the revolutionary GUI to become a so-called "standard" before the original developers even consider bringing legal action. At this rate, the only viable option for smaller players would be to develop their GUI offline and in secret. Then, once the GUI is completed, they may be able to convince a dominant player to purchase it from them. Thus, effectively, sell out, and further fuel the existing monopolies in the industry instead of competing. It is thus necessary to protect GUIs, irrespective of how popular they may prove to be. As noted above,

\footnotetext{
${ }^{51}$ The law intrinsically prevents this. See discussion at Section 3.1.3: Expanding the scope of protection for industrial designs.

${ }^{52}$ Gregory Sidak "The Meaning of FRAND, Part I: Royalties" (2013) 9 JCL \& E 931 at 949.

${ }^{53}$ Rachel Stigler "Ooey GUI: The Messy Protection of Graphical User Interfaces" (2014) 12(3) Nw J Tech \& Intell Prop 215 at 224.
} 
the law should require building-block-type gestures, such as the opening of the hand, to be subject to compulsory licencing, so as not to stifle further development. At the very least, however, the revenue from licensing fees enables original developers from smaller companies to grow to a stage where they can viably compete with those that currently dominate the industry. Taking account of the speed of development in the industry, it may also be necessary, as Rachel Stigler suggests, to reduce the term of protection for GUIs. ${ }^{54}$

Even if the underlying software cannot be protected due to being a building block, this does not explain why, for example, the menu design of nearly every smartphone or tablet mimics the design originally created by Apple Inc. ${ }^{55}$ Stigler points out that: ${ }^{56}$

Unlike interoperable code, whose function can often be achieved through a very limited number of ways, there are an infinite number of ways to graphically express a certain function.

Although the underlying software may well be a necessary component for further development, it is often the design that is the main source of appeal, because, as a legal advisor specialising in intellectual property (legal advisor ' $\mathrm{N}$ ') pointed out, "what a product looks like ... is a huge factor in whether people buy it."

For this reason, it is important to distinguish these concepts so as not to allow the copying of virtual designs to be an exception to infringement under the guise of being a building block. Even if building-block software underlying a GUI, for example, is not protected, at the very

\footnotetext{
${ }_{54}^{54} \mathrm{Ibid}$, at 249. See also the discussion in Section 6.3.1: Duration of protection for industrial designs.

${ }^{55}$ Ibid, at 223.

${ }^{56}$ Ibid, at 224.
} 
least, its appearance, including features such as animations in response to user interaction, should be.

However, as with physical designs, copyright protection for virtual designs must be limited solely to the expression, and should not extend to the underlying idea. To ensure this, care should be taken in discerning originality in virtual designs and in particular virtual multisensory designs.

\subsubsection{Determining originality in cases of multisensory designs}

As society continues to engage more and more with virtual spaces, the issue of determining originality in multisensory design expression will only continue to grow in relevance.

It is suggested here that originality in multisensory expression should be determined via a "general look and feel" test.

Although a "general look and feel" test has not thus far been applied with respect to multisensory designs (at least not virtual multisensory designs), this type of assessment has been utilised by the New Zealand High Court in assessing the objective similarity, ${ }^{57}$ of GUIs, for the purposes of determining whether or not there has been infringement by copying. ${ }^{58}$ In Muzz Buzz Franchising Pty Ltd v JB Holdings, ${ }^{59}$ Toogood J applied a "general look and feel"

\footnotetext{
${ }^{57}$ Objective similarity is one of the required elements for establishing infringement by copying - see Section: 3.3.3.4: Scope of Protection.

${ }^{58}$ For discussion of the required elements for establishing infringement by copying - see Section: 3.3.3.4: Scope of Protection.

${ }^{59}$ Muzz Buzz Franchising Pty Ltd v JB Holdings [2013] NZHC 1599.
} 
test for this purpose. ${ }^{60}$ The GUI at issue in this case was a website, which the court, in establishing infringement by copying, held was objectively similar to the original. ${ }^{61}$

A "general look and feel" test has also been applied in New Zealand in a case involving what could be classified as a multisensory design. Although the design was not virtual, the High Court in Dreamtech Designs \& Productions Pty Limited v Clownfish Entertainment Limited (Dreamtech Designs), ${ }^{62}$ granted an interim injunction and held that there was a serious question to be tried, that the setup of a haunted house in its entirety was a "work of artistic craftsmanship". ${ }^{63}$ A haunted house in its entirety is arguably a design for multiple senses.

Woolford $\mathbf{J}$ explained that the objects contained in the house were not assessed individually, ${ }^{64}$ that is, every prop in its precise position, in relation to certain parameters of the facility, and so on. Rather, the space and environment was considered as a whole, ${ }^{65}$ and as such a "general look and feel test" was applied. In his reasoning, Woolford J explained:

Although when each component room is described, it can be reduced to mere ideas, the copyright claim is in relation to the overall look and expression of those ideas.

Although not explicitly mentioned by Woolford J, the "likelihood of confusion" test applied in passing off tort cases ${ }^{66}$ may be of assistance in determining whether the "general look and feel" of a design has been copied. The European Union's (EU) "distinct character" test for unregistered designs also seems to be an assessment of "general look and feel". The

\footnotetext{
${ }^{60}$ See Ibid at [49].

${ }^{61} \mathrm{Ibid}$, at [52].

${ }^{62}$ Dreamtech Designs \& Productions Pty Limited v Clownfish Entertainment Limited [2015] NZHC 1143.

${ }^{63}$ Ibid at [33].

${ }^{64} \mathrm{Ibid}$, at [27].

${ }^{65} \mathrm{Ibid}$, at [31].

${ }^{66}$ Alan Nemes and Anna Carboni "Overlapping Rights in Designs, Trademarks and Trade Dress" in Neil Wilkof and Shamnad Basheer (eds) Overlapping Intellectual Property Rights (Oxford University Press, Oxford, 2012) 251 at 262.
} 
requirement is that the design must have a different overall impression on consumers to previous designs. ${ }^{67}$ This is similar to the EU's "global appreciation" test for trade marks, which is also an overall impression-based assessment. The average consumer (unlike the informed observer in registered design assessments) has imperfect recollection. Thus, their recollection is limited to a general impression. It is not, however, limited to visual features, but extends to aural and conceptual impression as well. ${ }^{68}$ This broader general impression assessment is likely to be most appropriate for cases involving multisensory industrial designs, because, as Elli Cho explains, the human sensory experience and how we perceive things is necessarily subjective. ${ }^{69}$ Thus, at most, we can only narrow down a design that attracts multiple senses to a general perception, hence the "general look and feel" of it. The question, as academic ' $\mathrm{D}$ ' pointed out, is:

What is the essence of the product? If it was broadened to the essence of the product, rather than any particular quality, then you could isolate out its unique character.

Academic 'S', to the contrary, did not like the idea of a "general look and feel" test. They stated:

Can experiences really be copyrighted? It becomes complicated when we start to talk about things like interfaces. It is one thing if I create a fantastic character, but I think we have to find that balance, otherwise it will serve as a chilling effect on the rest of development.

Company 'E' was not in favour of a "general look and feel" test either, stating: "you could waste a lot of money ... arguing overall impression of an aesthetic. That is very subjective".

\footnotetext{
${ }^{67}$ Ibid, at 263.

${ }^{68} \mathrm{Ibid}$, at 272.

${ }^{69}$ Elli Cho "Copyright of Trade Dress toward IP Protection of Multisensory Effect Designs for Immersive Virtual Environments” (2015) 33 Cardozo Arts \& Ent L J 801 at 823.
} 
In terms of the decision in Dreamtech Designs, academic ' $S$ ' made the following observation:

It makes me think of the general look and feel of Disney's haunted mansion. The big moment at the end is where you are looking at yourself in the mirror and you see a ghost sitting next to you. So the idea is that they have stuff moving behind the one-way glass. It is lit in a particular way so that you reflect off the mirror, but the objects behind the mirror are bright enough that they shine through the one-way. That is an experience, in that you are sitting there looking in the mirror and seeing a ghost sitting next to you. Now how can that be protected?

A legal advisor specialising in intellectual property (legal advisor ' $L$ ') was of a similar opinion with respect to the decision in Dreamtech Designs, stating:

I am ... surprised that the High Court considered that there was a serious question to be tried as to infringement because with copyright you are not supposed to protect the idea by itself and I ... thought it was really about the idea rather than the expression of an idea. To me it ... sounded like the court wanted to give it protection, so they decided to call it a "work of artistic craftsmanship", when in actual fact I think it was more of a concept or an idea.

The above observations, suggesting that such experiences are more analogous to ideas as opposed to original expressions, resemble the reasoning for abandoning the "general look and feel" test in the United States copyright infringement case of Apple Computer v Microsoft Corp. $^{70}$

\footnotetext{
${ }^{70}$ See Apple Computer v Microsoft Corp 35 F 3d 1435 (9th Cir 1994).
} 
These are plausible observations. Indeed, the idea of looking in the mirror and seeing a ghost, as in the example provided by academic ' $\mathrm{S}$ ' above, is probably too general to be reasonably considered an original expression. However, the particular ghost in Disney's mansion, its particular appearance (that is, its particular dress and makeup), in the particular lighting and surroundings, may well be an original expression. Identifying the original expression becomes significantly easier when there are effects incorporated for other senses as well, such as, for example, a particular smell that emanates in time with the ghost's visual appearance.

A "general look and feel" test is therefore an appropriate means of discerning original expression in multisensory works. Once original expression is discerned, protection for such works should be provided, under a new copyright category, as suggested above. ${ }^{71}$ Some multisensory works may also qualify under the "work of artistic craftsmanship" classification. This classification is however rather ambiguous. ${ }^{72}$ The following section discusses how this ambiguity could be mitigated.

\subsubsection{Applicability of the "work of artistic craftsmanship" classification}

As was explained in Chapter 3, it is clear that the "work of artistic craftsmanship" classification extends to some original industrial designs. The designs must have eye appeal and some other characteristic of artistic quality. This other characteristic is not related to the profession of the creator of the design nor is it evidence of some authentic design lineage. Neither is it necessarily the intention of the creator to create a "work of artistic craftsmanship". What it is precisely,

\footnotetext{
${ }^{71}$ See discussion in Section 6.1.1.3: Should non-visual/auditory expression be protected?

${ }^{72}$ See discussion in Section 3.3.3.2.1: Work of artistic craftsmanship.
} 
however, is unclear. Therefore, at present, applicability of the classification is determined on a case by case basis.

The majority of the legal practitioners/advisors specialising in intellectual property who were interviewed agreed that it was best to leave the classification for the courts to continue interpreting on a case by case basis. Their reason was succinctly stated by legal practitioner 'I': I do not think you could ever clarify it any better in legislation. Clearly it means different things in different industries.

In its current state, "courts have flexibility to interpret the definition and to change the definition to meet the particular circumstances", a legal advisor specialising in intellectual property (legal advisor ' $\mathrm{V}$ ') explained. They did, however, note that in the context of New Zealand:

An argument could be made for more prescriptive legislation ... as ... the case law is very slow to develop in New Zealand. Whereas in a highly litigious environment, like the United States, they probably do not need quite so much prescriptiveness in legislation because the courts will appropriately develop it over time.

Indeed, compared to the United States there have been very few copyright cases in New Zealand. In light of this fact, the suggestion of providing a legislative definition does not seem entirely inappropriate.

As legal advisor ' $L$ ' pointed out, there are clear "advantages of codifying, in that designers and legal advisors ... would have ... greater certainty about what may or may not be included". In addition to a definition, the inclusion of some obvious examples in the legislation could perhaps shed some light on the mystery ingredient in "work of artistic craftsmanship" and assist courts 
in their determinations. Examples are included in the latest draft revision of the Copyright Law of the People's Republic of China. ${ }^{73}$ In the opinion of a legal practitioner specialising in intellectual property (legal practitioner 'O'), examples are not a good idea because they “may be misleading, or may only be useful to something like one of four thousand works." It is important to note, however, that legal practitioner ' $\mathrm{O}$ ' was specifically concerned about reliance on examples as the basis for arguing one's rights in a work. Such a proposition in court “would be laughed at", legal practitioner ' $\mathrm{O}$ ' stated, before noting:

At best, they [examples] form a way to explain and shed light on the section. So they are a guide only. You certainly would not cite them as such. What you might do is use them to expand your reasoning and to direct your reasoning as to why a particular act by a third party would infringe your rights.

Indeed, examples are only potentially useful as a guide and nothing more. Perhaps what would make them a more useful guide, however, is pictures. Legal advisor ' $\mathrm{L}$ ' approved of this suggestion, stating: "that would probably help a lot. I mean, why should we be restricted to only using words in statutes?"

As the English idiom goes "a picture is worth a thousand words". More precisely with regard to the law, pictures can assist words to convey complex ideas. ${ }^{74}$ Perhaps the primary reason why pictures are not typically included in legislation is that the law has essentially been a words-only creature for hundreds of years. ${ }^{75}$ This has been so, in part, due to the fact that, until relatively recently, the incorporation of images within text was not a particularly easy feat,

\footnotetext{
${ }^{73}$ See The Copyright Law of the People's Republic of China 1991 (3rd draft revision, released on 1 October 2012), art 3.9.

${ }^{74}$ Adam Rosman "Visualising the Law: Using Charts, Diagrams, and Other Images to Improve Legal Briefs" (2013) J Legal Educ 70 at 70.

${ }^{75}$ Ibid, at 71.
} 
technologically. ${ }^{76}$ Incorporation of images within text as opposed to appendences simplifies the task for the reader. Subject matter is usually significantly more comprehensible when the reader is not being referred elsewhere for details. ${ }^{77}$

Incorporation of images into New Zealand legislation is permissible. The Interpretation Act 1999 states "the matters that may be considered in ascertaining the meaning of an enactment include indications provided in the enactment. Examples of those indications are ... diagrams and graphics". 78

Graphic representation is a requirement for design registrations. ${ }^{79}$ Without the graphic representation, the design description will often be unintelligible. ${ }^{80}$ Similarly, images may prove crucial in defining "artistic craftsmanship". Perhaps one of the reasons "artistic craftsmanship" has proven impossible to define precisely is the fact that it is, to such a large extent, a visual concept. Images may better communicate that which cannot be precisely articulated in words, or they can at least serve as visual reference points, not in the sense of what the concept is limited to, but rather as an indication of a threshold, or perhaps the kind of standard of work expected.

It could be argued that such visual reference points could keep "artistic craftsmanship" at a twentieth or twenty-first century standard and prevent it from evolving. Although it is difficult to imagine that legal conceptions will restrict the imaginations of artist craftsmen, the point is

\footnotetext{
76 Ibid.

${ }^{77}$ Ibid, at 80 .

${ }^{78}$ Interpretation Act 1999 (NZ), s 5. Some statutes have incorporated images for the purposes of simplifying and clarifying the law for the reader. For example, to improve the readability of previous tax legislation, diagrams were included in the Income Tax Act 2007 (NZ). The Major Events Management Act 2007 (NZ) also includes images.

${ }^{79}$ See Design Regulations 1954 (NZ), reg 25.

${ }^{80}$ David Musker "The Overlap between Patent and Design Protection" in Neil Wilkof and Shamnad Basheer (eds) Overlapping Intellectual Property Rights (Oxford University Press, Oxford, 2012) 23 at 45.
} 
valid in that the legal conception must be ever evolving to keep up with practice. To ensure the legal conception is not outdated, it may be necessary to update the provided examples as new significant cases arise. It would be sensible, perhaps, to include such examples in supplementary regulations, rather than the Statute.

Unsurprisingly, the empirical investigation for this study revealed that interviewees from design-oriented industries were unsure of what precisely the classification required. Several were confident, however, that industrial designs, including 3D-printed articles, could qualify as "work of artistic craftsmanship". However, most of the interviewees thought that to qualify such articles would probably need to entail something more than designs usually produced in the ordinary course of one's business. This belief is analogous to Lord Simon's comments in George Hensher Limited $v$ Restawile Upholstery (Lancs) Limited, ${ }^{81}$ with respect to the blacksmith making a wrought iron gate. This is an example of work requiring something different to what is required in the blacksmith's ordinary course of business. ${ }^{82}$ To some extent, the difference between the ordinary work and work outside the ordinary course of business must lie in the creator's intention. However, intention is not a determinative factor in New Zealand. ${ }^{83}$

The other factor that sets "artistic craftsmanship" apart from "ordinary craftsmanship" is additional effort. This was the holding of Drummond $\mathbf{J}$ in the Australian Case of Coogi Australia Pty Ltd v Hysport International Pty Ltd. ${ }^{84}$ He held that the purpose of the inclusion of such works in copyright law is the encouragement of "real artistic effort". 85

\footnotetext{
${ }^{81}$ George Hensher Limited v Restawile Upholstery (Lancs) Limited [1974] FSR 173.

${ }^{82}$ Ibid, at [193].

${ }^{83}$ See Bonz Group (Pty) Ltd v Cooke [1994] 3 NZLR 216 (HC), at [223]-[224]; see also Copyright Committee Report Presented to the House of Representatives (NZ, 1959) at 115.

${ }^{84}$ Coogi Australia Pty Ltd v Hysport International Pty Ltd (1998) 86 FCR 154.

${ }^{85} \mathrm{Ibid}$, at 168.
} 
Additional effort in itself however, is unlikely to be enough. Similarly to the observation with respect to intention, ${ }^{86}$ one could, despite trying very hard, nevertheless fail to achieve the desired effect or purpose. Therefore effort as well as intention are perhaps better described as components of what actually sets artistic craftsmanship apart from ordinary craftsmanship, namely, skill.

Additional skill is certainly required in Lord Simon's example, because clearly a wrought iron gate requires more skill from the blacksmith than the skill required to shoe a horse. "Additional skill" is very likely the special ingredient of artistic quality required for "work of artistic craftsmanship". Tim Ingold explains that the word "art" is in fact derived from the Latin word "ars", which effectively means "skill" of the type typically associated with craftsmanship. ${ }^{87}$ Although, as explained in Chapter 3, it was relatively easy to discern "artistic craftsmanship" until well into the eighteenth century, when the industrial revolution and the rise of machine manufacture made it more difficult to distinguish the work of skilled craftsman. ${ }^{88}$ However, it is not impossible. Unfortunately, what is impossible, as Nicholai Bernstein observed, is the ability to deduce what constitutes "skill" to a workable formula. ${ }^{89}$

As such, it does not make sense to provide a definition for a concept containing a seemingly unmeasurable component. I think the inclusion of examples in legislation however, would be a pragmatic means to shed some light on the ambiguous concept. Examples can be utilised by parties in disputes, as well as judges, for the purposes of guiding or aiding their reasoning. Pictorial examples may prove as a useful reference point for what seems to be an unmeasurable

\footnotetext{
${ }^{86}$ See the discussion in Section 3.3.3.2.1: Work of artistic craftsmanship.

87 Tim Ingold The Perception of the Environment: Essays on Livelihood, Dwelling and Skill (Routledge, Abingdon, 2000) at 349.

${ }^{88}$ See the discussion in Section 3.3.3.2.1: Work of artistic craftsmanship.

${ }^{89}$ From Nicholai A Bernstein Dexterity and Its Development (L Erlbaum Associates, 1996), cited by Ingold, above n 87 , at 353 .
} 
component. Although there have been very few cases with respect to copyright in artistic craftsmanship in New Zealand, this is a forward looking recommendation. Thus, as noted above, it is suggested that examples should be included in supplementary regulations, rather than the Statute.

\subsection{Suggestions and Recommendations with Respect to Registered Designs}

Suggestions and recommendations with respect to the registered design system in New Zealand are provided below. There are five recommendations in total, concerning: the definition of design; the threshold for registration; the extent of examination required for registration; the adequacy of the New Zealand design register; and, finally, the notion of signing up to the international design registration system.

\subsubsection{Definition of "design"”}

The Oxford English Dictionary defines "design" as: "the arrangement of the features of an artefact, as produced from following a plan or drawing"; 90 and "industrial design" as: "the art or process of designing manufactured products". ${ }^{91}$ The Designs Act 1953 (Designs Act) defines a "design" as: 92

features of shape, configuration, pattern, or ornament applied to an article by any industrial process or means, being features which in the finished article appeal to and are judged solely by the eye; but does not include a method or principle of construction or

\footnotetext{
90 “English Oxford Living Dictionaries" (2017) Oxford University Press <https://en.oxforddictionaries.com>.

${ }^{91}$ Ibid.

${ }^{92}$ Designs Act 1953 (NZ), s 2. The definition is examined in the discussion of New Zealand design law in Chapter 3.
} 
features of shape or configuration which are dictated solely by the function which the article to be made in that shape or configuration has to perform.

Both the dictionary and legal definition recognise the decorative or visually aesthetic nature of design, but, as was evident in the discussion in Chapter $2,{ }^{93}$ this is only partly reflective of what the concept actually entails. This observation is not novel, however, for the legal definition in the New Zealand statute has been criticised since at least as early as 1966. At a meeting held by the New Zealand Chapter of the British Society of Industrial Artists at Wellington Polytechnic, several design students voiced their disapproval of the definition of "design" proposed in the first draft of the Industrial Designs Bill, ${ }^{94}$ a definition taken directly from the Designs Act. The students criticised the definition for its focus on the stylistic element of design, and its narrow conceptualisation of design. ${ }^{95}$

\subsubsection{Reference to "the eye"}

Perhaps the most obvious aspect, which unduly limits the definition of "design" in the Designs Act, is the reference to "the eye".

The phrase "features which in the finished article appeal to and are judged solely by the eye" 96 has the effect of excluding non-visual aesthetic aspects from the registered design system. As legal advisor ' $N$ ' pointed out:

Designs are not registered for smell or odours, you do not register designs for the way they feel to the touch, and you do not register designs for what they sound like.

\footnotetext{
${ }^{93}$ See Section 2.2: The Role of the Industrial Designer.

${ }^{94}$ Michael Smythe New Zealand by Design: A History of New Zealand Product Design (Godwit, Auckland, 2011) at 172 .

${ }^{95}$ Ibid.

${ }^{96}$ Designs Act 1953 (NZ), s 2(1).
} 
The current definition of design is very outdated. Academic ' $\mathrm{S}$ ' commented:

As we have seen, design for the past 10 years, maybe more, has been moving away from the aesthetics of an object, and much more towards the aesthetics of behaviour.

Multisensory design is, as academic ' $\mathrm{C}$ ' noted, "a topic of interaction design". As opposed to merely visual appeal, interaction design focuses on the more holistic experience of the user's interaction with the product, hence the aesthetics of behaviour. For this reason, it is arguably time to remove the reference to "the eye" from the definition.

An example of a definition more accommodating to non-visual aesthetic design aspects is the definition of 'industrial design' in the Industrial Designs Act 1966 (Industrial Designs Act): ${ }^{97}$ "the practice of planning the properties or the presentation, of the products of industry with the object of improving their quality, utility and appearance."

The wording of this definition appears flexible enough to accommodate the non-visual aesthetic design aspects, as these aspects of design could arguably be described as improving product quality. The Industrial Designs Act definition, however, was describing the profession of industrial designers, rather than industrial design as a concept. Moreover, "quality" in the context of design can be interpreted broadly. There are two types of quality in design, namely "hard" and "soft". ${ }^{98}$ Soft quality concerns things such as aesthetics and even environmental friendliness. ${ }^{99}$ Hard quality is concerned with the technical and functional aspects of design, ${ }^{100}$ and is, in the intellectual property sense, much more within the domain of patent law. Thus, the

\footnotetext{
${ }^{97}$ Industrial Designs Act 1966 (NZ), s 2. Since repealed by the Testing Laboratory Registration Amendment Act 1988 (NZ).

98 Jonathan Cagan and Craig Vogel "Understanding and Protecting Value in New Product Development" (paper presented to the International Conference on Engineering Design, Stockholm, August 2003) at 6.

${ }^{99}$ Ibid.

${ }^{100}$ Ibid.
} 
broad interpretation of "quality" would also likely have the undesirable effect of extending the scope of protection too far, that is, to industrial designs dictated solely by function.

Ideally the definition should be clear and unambiguous. The definition from the Industrial Designs Act is not the only example of a definition that is sufficiently accommodating of nonvisual aesthetic design aspects. Several definitions have come out of the industrial design field that could be used as models worthy of consideration for amendment of the existing definition of "design" in the Designs Act. For example, industrial designer Dave O'Hare defined it as "the human interface of products which includes ergonomics such as feel, touch, colour, readability, accessibility, shape and form."

Alternatively, New Zealand might craft a new definition based on the definition of "design" provided in the Patent Law of the People's Republic of China: ${ }^{102}$

Designs means with respect to a product, new designs of the shape, pattern, or the combination thereof, or the combination of the colour with shape and pattern, which are rich in aesthetic appeal and are fit for industrial application.

China's revised draft of their Patent Law reads: "design means new design ... which creates an aesthetic feeling" (emphasis added). ${ }^{103}$ "Design" is clearly not restricted to visual aspects under these definitions, because there is no reference to "the eye".

\footnotetext{
${ }^{101}$ Smythe, above $\mathrm{n} 94$, at 210. For further helpful insight into what "industrial design" entails, as articulated by design academics and industrial designers, see Section 2.2: The Role of the Industrial Designer.

102 Patent Law of the People's Republic of China 1984 (as amended up to the decision of 27 December 2008, effective as of 1 October 2009), art 2.

${ }^{103}$ See Patent Law of the People's Republic of China 1984 (4th draft revision, released on 10 August 2012), art 2.
} 
The Chinese definition is a good model that New Zealand could adopt in reconceptualising its design definition as it is simple, clear and most importantly does not limit perception of design to "the eye." Such a definition would remove any existing basis for sense discrimination in the Designs Act.

\subsubsection{Application to an article}

Another unduly restrictive phrase within the definition of "design" in the Designs Act is the words "applied to an article". ${ }^{104}$ The limiting nature of the phrase is clearly evident when considering virtual designs. The suggestion that virtual designs are "applied to an article" is a good example of a phrase being unnaturally expanded for a purpose that was clearly never envisioned at the time the definition was drafted. Yet this is precisely what has been done in New Zealand when virtual designs have been registered. As noted in Chapter 5, a virtual design was registered in Altoweb Incorporated's Application (Altoweb). ${ }^{105}$ In its decision, the Patent Office of New Zealand referred to Suwa Seikosha's Design Application (Suwa Seikosha). ${ }^{106}$ In Suwa Seikosha the Registered Designs Appeal Tribunal in the United Kingdom held that the display design of a digital watch was registrable, even though it was transitory, because the display design could be seen when the watch was used for its intended purpose. ${ }^{107}$ For the Patent Office of New Zealand in Altoweb, such an interpretation of "applied to an article" appropriately took account of technological developments. ${ }^{108}$

\footnotetext{
${ }^{104}$ Designs Act 1953 (NZ), s 2(1).

105 Altoweb Incorporated's Application [2000] IPONZ D1/2000.

${ }^{106}$ Suwa Seikosha's Design Application [1982] RPC 166.

107 Altoweb Incorporated's Application, above n 105, at [7].

${ }^{108}$ Ibid, at [8].
} 
Although it is true that legislation should be interpreted in light of changing circumstances, and that the prohibition of flexible interpretation has the effect of stifling competition, ${ }^{109}$ it is nonetheless important not to stretch words so far as to be inconsistent with their natural meaning.

As such, it is very likely that the virtual designs that have been registered in New Zealand under the existing definition, will, as legal advisor 'N' pointed out, have "no validation from a court", and will be held to be invalid if an infringement case were to be brought. "The courts ... probably would struggle ... to construe the legislation sufficiently to apply in a digital environment", commented legal advisor ' $\mathrm{V}$ '. Legal practitioner 'I' was of a similar opinion, stating:

If you tried to enforce it ... in court ... the defence would zero in on that aspect and say "well this is not being 'applied to an article'. It is a transient image." So I imagine a design like that, notwithstanding it has been granted, will be unenforceable under current law.

"It is kind of an artificial thing to say it is applied to a computer screen ... and ... it gets more and more ridiculous as time goes by", pointed out legal advisor 'L', before elaborating:

Today, we are accessing things on tablets, smartphones and so many things. In the future you can also imagine holograms and things like that. So there are going to be problems, I think, in the future.

The core of the problem seems to stem from a basic, but common, misapprehension as to the nature of virtual designs. The relevant articles we consider when we think of virtual designs are things such as the television, the smartphone, the computer, the tablet, etc. A virtual design

${ }^{109}$ Musker, above n 80, at 26. 
is not applied to, embodied in, or even associated with any of these articles. These articles are platforms for virtual designs. In other words, they are simply tools that allow us to perceive or sense the virtual data, in the same way a person's nose allows them to sense smell, for example. The fact that one can smell a scent with their nose does not mean that the scent is applied to, embodied in, or even associated with their nose.

Virtual designs are not designs in a physical sense and are therefore not "applied to" any "article" per se. Rather, they have a life of their own, but are accessible by means of a variety of articles that are capable of displaying virtual designs.

In 2012, the Australian Government asked the Advisory Council on Intellectual Property to review the registered design regime. In their 2015 report, the Advisory Council on Intellectual Property noted that to put virtual designs within the registrable scope, the definition would need to be relaxed to include designs "visible in" a product. ${ }^{110}$ Adding the words "or visible in" after the words "applied to" appears to be an appropriate amendment, and is worthy of consideration in New Zealand for the definition of "design" in the Designs Act.

Alternatively, the definition could be amended in the manner suggested by the Ministry of Law and the Intellectual Property Office of Singapore in their review of the Registered Designs Act in Singapore, ${ }^{111}$ which uses essentially the same wording in its definition of "design" as New Zealand. ${ }^{112}$ The Ministry of Law and the Intellectual Property Office of Singapore recommended that the words "article of manufacture" should be replaced with the word

\footnotetext{
110 The Advisory Council on Intellectual Property Review of the Designs System (AU, 2015) at 31.

${ }^{111}$ See Ministry of Law and the Intellectual Property Office of Singapore Final Report Review of Singapore's Registered Designs Regime (2016).

${ }^{112}$ Essentially the same wording is used because Singapore's Registered Designs Act was based on the United Kingdom's Registered Designs Act 1949.
} 
"product". ${ }^{113}$ The words "article of manufacture" were originally introduced in the United Kingdom in the Copyright of Designs Act 1839. Prior to this Act, only design applied to textiles could be protected. The 1839 Act extended the protection to any "article of manufacture". ${ }^{114}$ In New Zealand, the definition of the word "article" in the Designs Act is also restricted to "articles of manufacture". ${ }^{115}$

Although "article of manufacture" has not been further defined, in the opinion of legal practitioner ' $\mathrm{O}$ ' "an article of manufacture could be one that is manufactured digitally." Howe et al, however, explain that when it was first introduced in the United Kingdom, the purpose of the phrase was to restrict protection to the manufacturing industry. ${ }^{116}$ A company in the virtual reality field (company ' $\mathrm{T}$ ') observed that, as this is the intended purpose for the inclusion of the phrase, virtual designs are unlikely to be protected under the Designs Act. They stated:

That needs a review, obviously. Manufacturing is a commodity. It is the very last step of turning a design into something real. So what? It's a spectrum, from being drawn on paper, to the real working thing. In the 1830 s you had a pen, paper and maybe a ruler. So you could only get so far virtually and the rest you had to do physically. Now, you can simulate every aspect of it. You can render it photo realistically, see exactly how it is going to behave in light and respond to other elements. You can get so much further virtually now, but the legislation seems to apply only to the first scenario.

\footnotetext{
${ }^{113}$ Ministry of Law and the Intellectual Property Office of Singapore, above n 111, at [2.1.8].

${ }_{114}$ Martin Howe, James St Ville and Ashton Chantrielle Russell-Clarke and Howe on Industrial Designs (9th ed, Sweet \& Maxwell, London, 2016) at [1-016].

115 Designs Act 1953 (NZ), s 2(1).

${ }^{116}$ Howe, St Ville and Chantrielle, above n 114, at [3-027].
} 
The Ministry of Law and the Intellectual Property Office of Singapore plausibly observe that virtual designs could not in themselves be considered articles of manufacture, ${ }^{117}$ as they are more likely to be created in the information technology industry.

As expanding the meaning of the wording in the existing definition of the Designs Act so as to extend protection to virtual designs essentially means interpreting words inconsistently with their natural meaning, it is appropriate to update the wording via a legislative amendment. The amendment, discussed above, which was suggested by the Australian Advisory Council on Intellectual Property would be appropriate in New Zealand, with a slight variation. The words "or visible in" should be substituted for the words "or perceivable in". With these words following the words "applied to" in the current definition, protection will not only be extended to include virtual design, but will also clearly extend beyond the visual aspects of design.

\subsubsection{Threshold for registration}

Problems with the existing Designs Act are not limited to the definition of "design". There is also a potential issue with the current wording that prescribes the threshold for registration.

The word "original" may be causing examiners to assimilate the requirement with the lower threshold requirement for copyright. ${ }^{118}$ As a result, "the value of a registered design ... is decreased $\ldots$ because you are making it relatively easy or easier for someone to vary an existing product and then get a new design”, legal advisor 'L' explained.

\footnotetext{
${ }^{117}$ Ministry of Law and the Intellectual Property Office of Singapore, above n 111, at [2.1.6].

${ }^{118}$ See explanation in Section 3.2.3: TRIPS Agreement.
} 
The question is, therefore, should New Zealand adopt different wording, perhaps something similar to that of China, ${ }^{119}$ by, for example, replacing the word "original" with the word "distinctive"?

"I think it's semantics. Certainly for most of the products that designs are being filed for, this distinction has little relevance", stated a legal practitioner specialising in intellectual property (legal practitioner ' $\mathrm{M}$ ').

Legal advisor ' $L$ ' thought that "original and distinctive mean substantially the same thing", and suggested making the distinction more obvious:

You could talk about variations, which are known in the trade, for example. That is getting closer to something which a designer could look at and say "ok I know what variations are in the trade, therefore I would know that I should not be going within this sort of parameter."

Others, however, such as legal advisor ' $\mathrm{V}$ ', were of the opinion that " distinctive' is a higher threshold than 'original'”. Another legal practitioner specialising in intellectual property (legal practitioner ' $\mathrm{K}$ ') agreed: "I think that it would help to avoid registration of designs with low levels of distinctiveness by specifying that the design must be 'distinctive'." However, legal practitioner ' $\mathrm{K}$ ' also cautioned that "this does bring in a subjective interpretation, which can create uncertainty for those wanting to protect their designs with a design registration." Another drawback, legal advisor ' $\mathrm{V}$ ' noted, is that:

${ }^{119}$ See Patent Law of the People's Republic of China 1984 (2009), above n 102, at art 23. 
No one would be able to register any car tyre treads any more. So there would be no incentive for anyone, potentially, to produce new car tyre tread designs, even though they might hold the road better.

A non-specialist may not even notice a tyre tread design. So, from that perspective, how can such a design be considered new or original? Legal advisor ' $N$ ' was of the opinion that the wording in the existing requirement is already reflective of a higher threshold, if considered from the perspective of an experienced or educated eye. They used toothbrushes as an example to explain this:

When people look at these things, shall we say, with a kind of uneducated eye, they will say “they are pretty similar, why did they register those?" People looking at them with a well-educated eye will go "oh no there are design differences there." The differences might not be great to the uneducated eye and they might be ostensibly quite subtle, but nevertheless there are differences. To an experienced eye it is a significant variation.

The terms "educated eye" or "experienced eye" used by legal advisor 'N' are essentially describing the informed ordinary customer, from whose perspective newness or originality is meant to be determined. ${ }^{120}$ Variations should not be so subtle however, so as to be evident only to the expert. Alan Nemes and Anna Carboni explain that it would be absurd to determine newness or originality from the perspective of an expert eye, as obviously an expert is always going to be able to tell the difference, even in cases involving the most subtle of variations. ${ }^{121}$

Nevertheless, it is important that some design variations are registered, even if the informed ordinary customer does not immediately notice the difference from earlier designs.

\footnotetext{
${ }^{120}$ See Crocodile International Pte Ltd v Lacoste CIV-2014-485-9300 [2015] NZHC 2432, at [94].

${ }^{121}$ Nemes and Carboni, above $\mathrm{n}$ 66, at 260.
} 
“An example would be door handles", legal practitioner ' $\mathrm{O}$ ' pointed out, before elaborating: All door handles are basically an L shaped thing that you grab with your hand and then you actuate the lock or the latch. So there is really not that much difference. It is an L shape that can pivot. Well if that is the case, then everyone in the world will only ever have an L shaped pivot ... but people want variations. They want differences. They do not want to ... come home and have the same handle ... as in their business place. So ... minor variations can make huge differences in aesthetic appeal.

Sometimes, the variations may only become evident when observing how the design evolved over time. Legal advisor ' $\mathrm{N}$ ' explained:

They ... make little modifications ... and register them as the design develops. You see this all the time with products like cellphones and things like that. The design sort of stays the same, but evolves, and if you then look at those articles over a period of time ... you could say "oh yes, actually things have changed". It is not just because they have different functionality or improved functionality, it is also because they are slowly evolving the design features of their product.

The examples provided by legal advisor ' $\mathrm{N}$ ' and legal practitioner ' $\mathrm{O}$ ' clearly illustrate that minor variations in design may be very significant aesthetically. As such, the degree of newness or originality is "a subjective assessment based on how close the prior art is", legal practitioner ' $\mathrm{K}$ ' explained. Legal practitioner 'I' was of the opinion that, in today's world, it is often necessary to register minor variations. They pointed out that:

Nowadays, you are unlikely to get anything radically different on what has gone before, particularly in consumer products and the sort of things that registered designs are supposed to cover. Basically everything now is just incremental building on what has gone on before. So my feeling is, if ... it is different and it is not something that is solely functional ... then I think, yes, it should be registrable. 
This means monopolies obtained via registered designs are often very narrow. "An incremental change will probably bring it outside the scope of monopoly", legal practitioner 'I' noted. "A minor change away from a registered design that has only got the slight variation will be sufficient to avoid infringing that design', legal practitioner ' $O$ ' explained. This is, as legal practitioner ' $\mathrm{K}$ ' pointed out, because "the closeness of the prior art also affects the breadth of protection offered by the design.”

I think that in some instances, such as in the case of door handles, it does makes sense for small variations in design to be registered. This is because such variations are nevertheless substantially significant from an aesthetic point of view. This aligns with the purpose of the registered design system.

When alterations are so minor from an aesthetic perspective however, as to be barely noticeable to the informed ordinary customer, such as in the case of car tyre tread designs, it becomes difficult to fathom why such designs are being registered. Indeed, the definition in the Designs Act states that a design cannot be "dictated solely by ... function", ${ }^{122}$ thus allowing for designs with a substantial degree of functional aspects to be registered. Be that as it may, the purpose of the registered design system is primarily to protect that which appeals to the consumer. As explained in Chapter 3, it does not have to appeal aesthetically but it does have to attract the consumer. ${ }^{123}$ If however, it is primarily the function of the design, that informs the consumer's choice, then such a design should not be registered. The fact that such designs are being registered is cause for concern. The words "or original" "24 should therefore be substituted for

\footnotetext{
${ }^{122}$ See Designs Act 1953 (NZ), s 2.

${ }^{123}$ See discussion in Section 3.3.4.1.1 "Appeal to and judged solely by the eye".

${ }^{124}$ See Designs Act 1953 (NZ), s 5.
} 
the words "and distinctive" in the Designs Act, as this will make it clearer that the threshold for registration is significantly higher than the threshold for copyright protection.

\subsubsection{Extent of examination}

To ensure the threshold is, in practice, reflective of the legislative intention, perhaps even more important than the wording, is the actual process of examination. Currently, a substantive examination is not required for registration under the Designs Act: ${ }^{125}$

For the purpose of deciding whether a design is new or original the Commissioner may make such searches, if any, as he thinks fit.

To reiterate, in the absence of substantive examination, registration may, in essence, be nothing more than a placebo effect. Registrants pay an affordable fee for peace of mind in knowing that they have registered. In reality, however, there is no validity to this peace of mind, as some businesses whose registration validity is challenged discover when they lose in court, despite having paid for the protection. Design owners in countries that have substantive examination, in fact, tend to prefer their system, probably because they are better informed about its benefits. $^{126}$

However, although examination is discretionary in New Zealand, several legal practitioners/advisors claimed that it tends to be quite substantive in practice. Thus, whether it

\footnotetext{
${ }^{125}$ Designs Act 1953 (NZ), s 7(2).

${ }^{126}$ Ministry of Law and the Intellectual Property Office of Singapore Public Consultation on Proposed Changes to Singapore's Registered Designs Regime (2015) at [4.7].
} 
is or not, is a matter of opinion, ${ }^{127}$ but, even if one is satisfied that it is substantive, the fact that it is not required by law ${ }^{128}$ is still a matter for concern.

Since applicants are required to pay for the registration, a prior examination of their design to assess its compliance with legal requirements should be guaranteed. A substantive examination prior to registration should be a legal requirement to ensure that only designs which meet the threshold are registered.

\subsubsection{Adequacy of New Zealand design register}

If the design register were limited to designs that were, following examination, deemed to be fully legally compliant, there would still remain the practical issue of navigating the register. Although the register is itself reasonably straightforward to use, the search options are quite limited.

The easiest means to search for a design is via case numbers which are assigned to registered designs. ${ }^{129}$ Of course many of those searching the design register may not have a particular design in mind, but rather be more generally interested in discerning prior art.

It is also possible to search by other criteria, such as by design owners name or date of registration. ${ }^{130}$ What is clearly lacking however, is a simple search by category. It is possible to search by classifications, established by the Locarno Agreement. ${ }^{131}$ These are administrative

\footnotetext{
${ }^{127}$ Different points of view are provided in Section 3.3.4.4: Examination.

128 See Designs Act 1953 (NZ), s 7(2).

129 "Search for Existing Designs” (2018) Intellectual Property of New Zealand <www.iponz.govt.nz>.

130 Ibid.

${ }^{131}$ See Locarno Agreement Establishing an International Classification for Industrial Designs (as amended on 28 September 1979).
} 
classifications used by the World Intellectual Property Organisation (WIPO). ${ }^{132}$ The lay person however, is unlikely to be well versed in the different Locarno classification codes representing the different categories of designs.

The existing search options that are available on the New Zealand design register should be simplified. This could be achieved by sorting the designs in the register into simple (rather than coded) categories and sub-categories (for example, furniture - lounge, or furniture bedroom). Design owners would then be able to browse and more easily discern the prior art, allowing them to more easily determine whether or not their own design is "new or original".

The examiner who is required to determine whether a design is new or original, has access to a more sophisticated search system. Legal advisor ' $N$ ' explained:

The public just searches on the public database ... but on top of that the examiner has access to another search system that looks at the database and presents results in a more efficient way. So you can still search for the designs as a member of the public, but the search engine is not as efficient.

It is impossible to comment on the additional benefits of the examiners database without having access to it. The Hague Express database, ${ }^{133}$ is an example of a database which clearly has a better search engine than the New Zealand design register. The Hague Express contains international design registrations which have been published in the International Designs Bulletin. ${ }^{134}$ This database allows users to search by areas and fields and then further filter search

\footnotetext{
132 "Fact Sheet Design Searching" (2015) European IPR Helpdesk <www.iprhelpdesk.eu $>$ at 5.

${ }^{133}$ See "Hague Express" World Intellectual Property Organisation <www.wipo.int>.

${ }^{134}$ Fact Sheet Design Searching, above n 132, at 9.
} 
results by names, dates and countries. Moreover, the database has the added feature of suggesting potential matching fields when searching. ${ }^{135}$

A more user friendly register like the Hague Express should be accessible to the public in New Zealand. The inability to conduct a thorough search without the assistance of a legal practitioner has anti-competitive implications. Start-ups and other smaller business are unlikely to have the funds to hire a legal practitioner for what should be a reasonably straightforward task. The point of having a public register is effectively defeated if the general public is unable to conduct a thorough search without specialist assistance. For this reason, I think it is important to improve the search interface of the register.

\subsubsection{Acceding to the Hague Agreement (international design register)}

Despite the limitations of the design registration system in New Zealand, it should be noted that several companies that were interviewed raised greater concerns with respect to registering designs overseas. It is far too expensive for companies to register separately in every single country in which they operate. Moreover, the different requirements in each country make it a very slow process.

A single international registration system, such as the one established by the Hague Agreement, ${ }^{136}$ could perhaps serve as a stepping stone towards resolving this issue. In the midst of the current copyright review, the Ministry of Business, Innovation \& Employment has in its request for submissions paper noted, that it has received information that not being a signatory

\footnotetext{
${ }^{135}$ Ibid.

${ }^{136}$ See Hague Agreement Concerning the International Deposit of Industrial Designs (6 November 1925, entered into force 1 June 1928, as revised at London 1934, The Hague 1960, Monaco 1961, Stockholm 1967, amended 28 September 1979, and revised in Geneva 1999).
} 
to the Hague Agreement is making it more complicated and expensive for New Zealand industrial design owners to protect their designs overseas. ${ }^{137}$ It has thus requested submissions on the advantages or disadvantages of membership.

An obvious advantage is that the Hague registration system will usually be quicker and cheaper than registering in every country individually, because as many as 100 designs can be included in one application and only one registration fee needs to be paid to the World Intellectual Property Organization (WIPO). ${ }^{138}$ One need not worry about translation fees that would otherwise need to be paid when individually filing applications in countries with different languages. Moreover, as there is only one registration fee for all member states, one does not encounter the issue of having to pay in multiple different currencies. ${ }^{139}$ With a single international registration, one also need not worry about keeping track of the different registration renewal dates in different countries. ${ }^{140}$

Another potential advantage, from an economic perspective, is increased demand from nonresident design owners for the services of domestic intellectual property professionals such as lawyers and advisors. This was identified as an advantage by Intellectual Property Australia in their cost-benefit analysis report (IP Australia report). ${ }^{141}$ Although many of the advantages and disadvantages identified in the report were specific to Australia, this was one of the more general advantageous that will also likely be applicable to New Zealand.

\footnotetext{
${ }^{137}$ Ministry of Business, Innovation \& Employment Issues Paper: Review of the Copyright Act 1994 (2018) at 108.

138 William Fryer "International Industrial Design Protection Improvement: The Hague Agreement Revision" (1994) 2 U Balt Intell Prop L J 37 at 38.

139 The Hague System for the International Registration of Industrial Designs: Main Features and Advantages (WIPO, Geneva, 2017) at 11.

${ }^{140}$ Ibid.

${ }^{141}$ See IP Australia The Hague Agreement Concerning the International Registration of Industrial Designs: A cost-benefit analysis for Australia (2018) at 34.
} 
The related disadvantage identified in the IP Australia report is that domestic intellectual property professionals may actually lose out on work. Although their services may be required by more non-resident registered design owners in situations where designs are infringed, nonresidents will no longer require them for formalities such as filing and maintaining registrations. ${ }^{142}$ With a single international registration system, it is likely that design owners will employ the services of intellectual property professionals in their home country for this purpose. ${ }^{143}$

It was also noted in the IP Australia report that any reduction in translation costs is likely to be negligible, as design applications typically have very little text to translate anyway. Moreover, several non-English speaking countries, nevertheless permit applications to be filed in English. ${ }^{144}$

The overall cost of a single international registration will not always be cheaper than registering separately in different countries. Legal advisor ' $\mathrm{V}$ ' pointed out:

There is a break-even point between the numbers of countries where you want protection versus the cost to make an application. The rule of thumb with the Hague Agreement is, you need to be looking at design protection in three or more countries for it to be cost effective. Otherwise, it is cheaper and more cost effective to go the national route.

If one wishes to register in three or more countries, then, legal advisor ' $\mathrm{V}$ ' explained, the Hague registration system will usually be more cost effective, because:

There is a presumption that once WIPO examines ... the application ... and is satisfied that the application meets their requirements, it [the design] is deemed to be registered in

\footnotetext{
142 Ibid, at 35 .

${ }^{143}$ Ibid, at 41

${ }^{144}$ Ibid, at 27.
} 
every member country in which protection was sought, unless that country objects to the registration.

Even in instances where the Hague registration system proves cost effective, it is important to bear in mind that the streamlined process is with respect to the formalities of registration only. ${ }^{145}$ The International Bureau only examines the application to the extent that it complies with formal requirements such as the payment of fees and quality of the required depictions. ${ }^{146}$ As there remains significant diversity in the domestic laws of different member states, the substantive examination, if any, is conducted at the state level. ${ }^{147}$

Certain countries may, require additional drawings and written descriptions, to accompany applications. ${ }^{148}$ Thus, in effect, a single international application under the Hague Agreement may nonetheless require applicants to provide several supplementary materials for each country where they wish their industrial design to be registered. ${ }^{149}$

It is also noteworthy that despite their being 69 contracting states, the Hague registration system, is not, the primary route for design registration internationally. In 2016, the Hague registration system accounted for just $15.8 \%$ of non-resident registrations worldwide. ${ }^{150}$

Despite the low overall utilisation of the system, the number of registrations did actually increase by $35.6 \%$ on the previous year. ${ }^{151}$ Moreover, despite the drawbacks of the system

\footnotetext{
${ }^{145}$ The Hague System for the International Registration of Industrial Designs, above n 139 at 10.

146 Ibid, at 9.

${ }^{147}$ Anna Kingsbury "International Harmonisation of Designs Law: the Case for Diversity" (2010) 8 EIPR 382 and 386 .

${ }^{148}$ The Advisory Council on Intellectual Property, above n 110, at 16.

${ }^{149}$ Ibid.

${ }^{150}$ World Intellectual Property Indicators (prepared by World Intellectual Property Organization, 2017) at 158.

${ }^{151}$ Ibid .
} 
noted above, it may still be useful for New Zealand companies operating in several overseas markets, provided such companies still had the option to apply in certain countries separately alongside that. Legal practitioner ' $\mathrm{O}$ ' explained:

A blanket application ... could be useful for protection in countries that we are not so concerned about because they are not big markets for us. Whereas ... in countries where we have a lot of market activity or where the market is strong, we need the ability to adjust our application, to the local conditions.

Although the overall conclusion in the IP Australia report was that the costs of signing up to the Hague Agreement outweighed the benefits, it noted that this could change if New Zealand and China (Australia's two largest registration destinations outside the domestic market) were to become members. ${ }^{152}$ The advantages of signing up to the Hague Agreement at present, do not appear to outweigh the disadvantages. However, as noted in the IP Australia report, it is likely, the tipping point of the international register's popularity, will occur with China's accession to the Hague Agreement. ${ }^{153}$ China has in fact made recent indications of its intention to become a member. ${ }^{154}$ If this happens, it may become more beneficial for New Zealand to sign up to the Hague Agreement.

\subsection{Suggestions and Recommendations with Respect to Industrial Design Protection}

\section{Generally}

The following suggestions and recommendations are not specific to a particular intellectual property protection mechanism, but, rather, address issues that are relevant to industrial design

\footnotetext{
${ }^{152}$ IP Australia, above n 141, at 11.

${ }^{153} \mathrm{Ibid}$, at 36.

${ }^{154}$ See Cao Yin "China negotiates to join Hague System protecting industrial design patents" (2019) China Daily $\langle$ www.chinadaily.com>.
} 
protection generally. These issues are the duration of protection, the potential usefulness of a "spare parts exception" and mitigating the negative impact of 3D printing.

\subsubsection{Duration of protection for industrial designs}

Several interviewees suggested that it may be necessary to amend the term of protection for designs from more traditional industries, such as the classical furniture industry.

New Zealand has an obligation under the Agreement on Trade-Related Aspects of Intellectual Property Rights (TRIPS) to provide at least 10 years' protection. ${ }^{155}$ This means, law makers have the flexibility to make protection as long as necessary. What is appropriate is of course informed by a policy process. Thus, prior to making any amendments to the term there must be evidence that there is a problem with the current term. Several legal practitioners/advisors interviewed opined that the existing terms available under both the copyright and the registered design systems are essentially appropriate, because they strike the right balance between not unduly impeding on competition in the market on the one hand, and allowing the design owner to gain a return on their investment on the other.

Legal practitioner ' $\mathrm{O}$ ' explained that the term is appropriate, because both copyright and registration are "easier to obtain than a patent ... and so ... should last less [time]".

By the end of the available terms, namely 16 years for copyright and 15 years for registered designs, "the product design is usually obsolete" anyway, noted legal practitioner 'M'.

\footnotetext{
${ }^{155}$ See Agreement on Trade-Related Aspects of Intellectual Property Rights (15 April 1994, entered into force 1 January 1995), art 26(3).
} 


\subsubsection{Classical furniture industry}

Usually the argument that the term of protection is insufficient seems implausible, but not in all instances. Although legal practitioner 'I' suggested the terms were appropriate, they nevertheless acknowledged that this was so only with regard to "the average product, like a kettle, or something like that." With regard to certain industries, however, such as the classical furniture industry, there may be a stronger argument to be had for a longer term of protection. In the following statement, a design-driven company (company ' $G$ ') provides a good basis for the argument that the existing terms of protection may not be sufficient:

For new products we have to spend 10 or 20 thousand dollars to get the required certifications (product safety standards). Then, of course, there is all the time spent developing a new design, making prototypes and paying your designers. It takes years and years, time and money to get to the point where you have created that design. We need to have 70 years to get it back. 15 years is ridiculous. You are not going to recoup the investment, because for new products, sales increase exponentially. The first few years ... before word gets out, and people see it ... sales are really slow. Shops are very slow to take on new products. They watch what other people are selling. After about 10 years you are beginning to get a rise in sales ... but the full impact ... may come 15 or 20 years later ... but by that point it [the protection] has been cut off.

A furniture design company (company ' $\mathrm{H}$ ') also wanted significantly longer protection than what is currently available, stating:

It would be good to see the protection time extended to 50 years. That would make a huge difference. All these designers who have now passed on would be horrified to see cheap approximates made of the design that they worked on for years. The designs we work with are not something that we are going to sell just this year and then move onto a new 
design next year. A lot of designs we are working with were designed in the early part of the twentieth century.

Some interviewees from industries where longer protection is less likely to be required acknowledged that it may nevertheless be necessary in the classical furniture industry. For example, company ' $E$ ' observed that "for designers that have made amazing furniture ... it is different." As there are different circumstances as well as different considerations in the different industries, it is perhaps necessary, as a design consultancy firm (company ' $A$ ') suggested, to provide "different lengths of time based on how long it is going to take to commercialise [the design]".

\subsubsection{Work of artistic craftsmanship}

Although it may well be necessary to extend the term of protection for classical furniture designs under the registered design system, it is likely that such designs may actually already be protected for 25 years by copyright law, as opposed to only 16, as they may be categorised as 'work of artistic craftsmanship". ${ }^{156}$ Academic 'C' explained why classical furniture is likely to qualify as "work of artistic craftsmanship":

Rare productions of really famous furniture ... designed by people like Charles and Ray Eames ... have actually proven that they have a track record. They have a history, as craftsmen ... and have proven that they are very creative. So, for that, 25 years is probably fine. However, those people are very few and far between. Few people would actually have that as their object. Most designers would probably say "that is not going be my beall and end-all. I am going to go and design a lot of other stuff."

${ }^{156}$ See Copyright Act 1994 (NZ), s 75(1). 
For the few designers that are so inclined, " 25 years provides a bit longer to get a financial return', explained legal practitioner ' $M$ '. However, companies such as ' $G$ ' and ' $H$ ' are not likely to be aware that their designs are likely to qualify as "work of artistic craftsmanship", due to the ambiguity of the classification. ${ }^{157}$ Moreover, both companies suggested much longer terms of protection, namely 70 years and 50 years, respectively.

Although it seems the classical furniture industry may require a longer period of time to recoup their investment, the suggestion that they should receive beyond 25 years protection due to the fact that their designs are still able to be sold after that time is something else entirely. The fact that a design continues to be popular is not justification in itself for extended protection. It must be remembered that intellectual property rights provide a period of time to gain a return on one's investment and, as such, serve as an incentive for creativity. This incentive, however, must always be balanced with the interests of competition so as not to stifle further creativity and development in the market. Protection should therefore only be granted for as long as is necessary to achieve that balance. ${ }^{158}$

However, it is noteworthy that other types of copyright works, even when applied industrially (in the sense that more than 50 copies in 3 dimensions are made for the purposes of sale or hire, such as a book), ${ }^{159}$ receive the full, unrestricted term of copyright protection. Thus, it is arguable that, for the sake of fairness, the industrial application restriction should be removed from the Copyright Act altogether. An amendment to this effect has been in force in the United Kingdom since 28 July $2016 .{ }^{160}$ As indicated above, however, in the opinions of the legal

\footnotetext{
${ }^{157}$ See above, Section 6.1.4: Applicability of the "work of artistic craftsmanship" classification.

${ }^{158}$ For further discussion on balancing interests in determining duration of protection - see Section 6.3.1.4: Industry specific duration - a balancing exercise.

159 This is the "industrial application" qualification for "artistic works" - see Copyright Act 1994 (NZ), s 75(4).

${ }^{160}$ Intellectual Property Office Repeal of Section 52 of the Copyright, Designs and Patents Act 1988: Guidance for affected individuals, organisations and businesses (2017) at 5.
} 
practitioners/advisors interviewed in the course of this study, such extensive protection would not be appropriate for industrial designs. Perhaps the reverse is even worthy of consideration, as industrial application seems to be recognised, in practice, with respect to works where legally such a distinction does not exist. For example, with respect to books, publishers often distinguish between commercial and literary fiction. It is, however, inappropriate to make any type of suggestions and recommendations with respect to other types of works, in the absence of an independent research investigation.

\subsubsection{Modern industrial designs}

With respect to industrial designs, several interviewees thought that extending the term of protection to the extent suggested by companies ' $G$ ' and ' $H$ ' would mean serving more than one generation. Some were strongly opposed to such extensive monopolies. For example, academic ' $D$ ' stated.

I personally think people should have to earn their own [living], and not just benefit from the thing that they have inherited from their grandparents. Quite often you will find people in design magazines talking about buying an original or an authentic [work], because there is some kind of ethical question there, but I say "the people that made it are dead. Who are we protecting here?" I mean, I get it, someone is trying to get a return on capital they invested, but for something that has been in production for 50 years, I think that is pretty scary.

Academic ' $\mathrm{D}$ ' was actually of the opinion that even the existing 15- and 16-year terms were too excessive for most industrial designs, stating:

I would make it six or five years. If you have not made it after five years, what good is it? It also clears the market for other people to take those designs and reuse them. People 
often say to me, "but you put all that time into it", and I say "yes, but I do not expect to own it forever."

In certain industries, even 10 years is often too excessive, a multinational company (company 'B') observed. They explained:

The world moves fast ... so five years, three years, two years even. You should be afforded the right to offer your product without it being copied, but 15 years means nothing. The additional time ... is not going to give you any real value, compared to what happens in that first year or two.

Legal practitioner ' $\mathrm{K}$ ' also thought that the term of protection should be " 7 to 10 years, as many designs become obsolete after this time."

There is also a strong case for a significantly shorter term of protection in terms of virtual designs. Several companies actually choose to release their design into the public domain after only a few years. Academic ' $S$ ' provided the following example:

A design studio in Boston called Nervous System ... writes software programs that replicate natural forms like mould or coral ... and then prints them as jewellery. What is interesting is that they will do a fashion show, create a line, sell it for a year or two and then they will ... put it up on Thingiverse, so that people can print the designs themselves. So they reserve a certain amount of time where they are the controllers of the designs and then ... pass it onto the public because they believe in open source.

Aside from believing in open source, the decision to release designs into the public domain after just a few years is also a likely result of the rapid pace of the information technology industry. Many virtual designs are likely to become obsolete after a short while. Thus, it makes 
sense to have a reduced term of protection for these designs. A reduced term of protection should ensure that exclusive rights do not unreasonably stifle creativity and innovation. ${ }^{161}$ The shorter term should encourage rights holders to make the most of their exclusive rights opportunity, including collaboration with others. ${ }^{162}$

From the above observation, it appears the minimum duration prescribed by TRIPS, ${ }^{163}$ may be too long for certain types of designs, in particular emerging designs from developing fields such as virtual reality. Such designs should be protected for a significantly shorter period of time to reflect the rapid pace of innovation and development in information technology and related fields. ${ }^{164}$ However, before protection terms can be reduced in New Zealand, the prescriptive provisions in TRIPS and the Berne Convention will need to be amended, ${ }^{165}$ or perhaps a new international treaty should be drafted to supersede the relevant provisions with respect to emerging designs.

\subsubsection{Industry specific duration - a balancing exercise}

In the event that the term prescribing provisions of TRIPS and the Berne Convention were amended or superseded, a balancing exercise would be necessary to determine the appropriate term, if any at all, in a particular industry. This is not simply a matter of balancing economic

\footnotetext{
161 “Are Efforts to Extend Patent and Copyright Laws Good for Business or Good for Society?" (2001) Wharton <www.knowledge.wharton.upenn.edu>.

162 Rebecca Giblin "Reimagining copyright's duration" in Rebecca Giblin and Kimberlee Weatherall (eds) What if we could reimagine copyright? (ANU Press, Australia, 2017) 177 at 198.

${ }^{163}$ See TRIPS, above n 155, at art 26(3).

${ }^{164}$ For discussion of the relevant considerations in the information technology industry - see Section: 6.1.2: Protecting virtual designs.

${ }^{165}$ In the context of the current copyright law review, the Ministry of Business, Innovation and Employment, has recognised that many people see a reduction in term as being beneficial. However, it will not be considering a reduction in term, due to New Zealand's international obligations under TRIPS and the Berne Convention - see Issues Paper: Review of the Copyright Act 1994, above n 141, at 36.
} 
interests. ${ }^{166}$ Essentially it is a policy question, namely whether the type of design is, from an instrumentalist perspective, socially desirable for production and dissemination, or from a naturalist perspective, sufficiently creative so as to be worthy of reward ${ }^{167}$ Drawing on the discussion of intellectual property protection rationales discussed in Chapter $3,{ }^{168}$ arguments are made for and against the expansion of protection to designs from developing fields, such as virtual reality.

If it is determined that the protection should be extended to designs created in developing fields, then the question that naturally follows, is the current term of protection appropriate for such designs?

\subsection{Arguments against expanding the scope of protection}

It is arguable that the scope of copyright protection should not be expanded so as to extend to works created in developing fields such as virtual reality, ${ }^{169}$ as there does not appear to be a lack of creativity in such fields. Anthony Reese suggests that where there is no evidence of creative deficit, protection is unlikely to serve the public interest. ${ }^{170}$ It may in fact counteract an existing creative culture in the particular field. Some creators, such as for example, some software developers in the information technology industry and related fields, have an inherent distrust for intellectual property protection, viewing it as an impediment to creativity and

\footnotetext{
166 See Section 3.1: Rationale for Protecting Industrial Designs.

167 Anthony Reese "What should copyright protect?" in Rebecca Giblin and Kimberlee Weatherall (eds) What if we could reimagine copyright? (ANU Press, Australia, 2017) 111 at 119.

${ }^{168}$ See Section 3.1: Rationale for Protecting Intellectual Property.

${ }^{169}$ For discussion of design in developing fields see Chapter 5.

${ }^{170}$ Reese, above n 167, at 118 .
} 
innovation. ${ }^{171}$ So they often choose to licence out their intellectual property via open source, which is the notion that existing works should be freely accessible to others. ${ }^{172}$

Another argument for why protection should not be provided to designs created in developing fields too readily, is that at the early stages of development, designs are more likely to comprise very broad ideas as opposed to discernible original expressions. From an instrumentalist perspective, the investment at the early stages of development, is usually not yet substantial enough for a want of recoupment, and the design, from a naturalist perspective, is too basic to warrant reward. ${ }^{173}$ Thus, it would not be in the public interest to provide the owners with exclusive rights at this stage, as such protection would likely slow down development, by serving as a roadblock for other, perhaps more creative individuals, working in the field. ${ }^{174}$

\subsection{Arguments for expanding the scope of protection}

Although there may not appear to be any lack of creativity in developing fields, such as virtual reality, it may still be in the public interest to protect the works being created in such fields.

On the one hand, it may well be that like the fashion industry in the United States, this creative field too, does not, from an instrumentalist rationale perspective, require monetary incentives. On the other hand, from a naturalist perspective, the creativity may neverthless be worthy of

\footnotetext{
${ }^{171}$ Christophe Geiger "Copyright as an access right: Securing cultural participation through the protection of creators' interests" in Rebecca Giblin and Kimberlee Weatherall (eds) What if we could reimagine copyright? (ANU Press, Australia, 2017) 73 at 75.

172 Judith Banister "Open Government: From Crown Copyright to the Creative Commons and Culture Change" (2011) 34(3) UNSW L J 1080 at 1099.

${ }^{173}$ Reese, above n 167, at 138.

${ }^{174}$ For discussion of design in developing fields see Chapter 5.

${ }^{174}$ Reese, above n 167, at 114.
} 
reward. As such, the reward would be a reflection of society's gratitude for the creation, as well as recognition that it is deserving of protection. ${ }^{175}$

From an equal treatment perspective it would be unfair and discriminatory to not extend protection where the creation is seen as being creatively worthy of reward. ${ }^{176}$ Thus, with respect to virtual expression for senses other than auditory or visual, protection should be extended to such works, provided they comprise creativity worthy of reward.

A work will not be sufficiently creative so as to be worthy of reward however, where original creative expression is not discernible. ${ }^{177}$ The reason why protection for expression communicating to senses other than auditory or visual, is not currently demanded is that the technology for communicating such expression is still at the relatively early stages of development. As such, creative expression communicating to senses other than auditory or visual, is for now, mostly limited to very general or vague concepts. ${ }^{178}$

Currently, virtual works communicating to senses other than auditory or visual are analogous to video game in the 1970 's. The individuals working in this field now are likely to share the mind-set of pioneer game developers, who generally invested in innovation rather than litigation. ${ }^{179}$ If there is anything worth protecting during the development stages, then it is likely to be novel technology. ${ }^{180}$ That is, novel technology which enables them to experiment

\footnotetext{
175 Giblin, above n 162, at 198.

${ }^{176}$ Enrico Bonadio and Nicola Lucchi "Introduction: setting the scene for non-conventional copyright" in Enrico Bonadio and Nicola Lucchi (eds) Non-Conventional Copyright (Edward Elgar Publishing, Cheltenham, 2018) 1 at 3 .

177 Ibid, at 14

${ }^{178}$ See Section 5.1.3: Multisensory Design.

${ }^{179}$ Greg Lastowka "Copyright Law and Video Games: A Brief History of an Interactive Medium" in Matthew David and Debora Halbert (eds) The SAGE Handbook of Intellectual Property (SAGE Publications, London, 2014) 495 at 500.

${ }^{180}$ Ibid.
} 
with communicating expressions to other senses. The appropriate intellectual property mechanism for protecting novel technology is the patent. ${ }^{181}$

It is likely that as the technology improves, those creating expressions for non-visual or auditory senses in virtual reality, will become increasingly interested in protecting the expressions themselves. ${ }^{182}$ Certainly this was the case with video games. As the intricacy of video games increased, so too, did the number of copyright infringement claims. ${ }^{183}$

It is important however that copyright is not extended to expressions communicating to senses other than auditory or visual until the originality of such expression is clearly discernible. At the current stage of virtual reality development, this is unlikely. ${ }^{184}$ However, it is foreseeable that such expressions will become discernible. ${ }^{185}$

The current definition of artistic work in the Copyright Act is arguably broad enough, to extend to original designs communicating to senses other than auditory or visual, and as such amendments by the legislature to protect such works may not be necessary.

The concern that such expansion may result in creators' of such works being awarded overly broad exclusive rights, should be alleviated with the appreciation that the law has the intrinsic flexibility to accommodate greater societal interests, by means of, for example, copyright's fair dealing provisions and the idea/expression dichotomy. ${ }^{186}$ Something as vague as a design

\footnotetext{
181 Ian Finch (ed) James and Wells Intellectual Property Law in New Zealand (3 ${ }^{\text {rd }}$ ed Thomson Reuters, Wellington, 2017) at 9.

182 Ansari, above n 47, at 1.

${ }^{183}$ Lastowka, above n 179, at 500.

${ }^{184}$ For discussion of how to discern originality in non-visual/auditory expression - see Section 6.1.1: Protection of non-visual/auditory expression.

${ }^{185}$ For an example of how such expression may be experienced in the foreseeable future - see Section 6.1.2: Protecting virtual designs.

${ }^{186}$ See discussion in Section 3.1.3.2: Arguments for expanding the scope of copyright.
} 
merely pleasant to the touch will never be able to be protected, even if the scope of copyright protection were to extend to tactile expression. ${ }^{187}$ The registered design system also provides for the greater societal interest of not stifling creativity, by prohibiting the protection of anything that is dictated solely by function. ${ }^{188}$

With such provision for the greater societal interest in place, expansion of copyright and registered design scope to works such as multisensory designs, should not diminish creativity in developing fields such as virtual reality. Thus once original expression in such works is discernible, protection should be provided.

As the extension of protection to works communicating to senses other than auditory or visual is a significant expansion of existing protection however, it may well be that designs created in the information technology industry and related fields, such as virtual reality, should be provided a shorter term of protection.

The duration of exclusive rights should reflect the appropriate compromise between the interests of the design owner and the greater public interest. ${ }^{189}$ A shorter duration is appropriate for some products and markets. ${ }^{190}$ For example, "artistic work that has been applied industrially" receives a much more limited term of protection in New Zealand law than most other types of copyright protected works. ${ }^{191}$ Aside from bringing it into alignment with

\footnotetext{
${ }^{187}$ For discussion of what discernible original tactile expression is likely to feel like - see Section 6.1.1: Protection of non-visual/auditory expression.

${ }^{188}$ See Designs Act 1953 (NZ), s 2.

${ }^{189}$ Graeme Austin "Copyright's Modest Ontology - Theory and Pragmatism in Eldred v Ashcroft" (2003) 16 Can JL \& Jurisprudence 163 at 172.

190 Tim Dornis "Non-conventional copyright: an economic perspective" in Enrico Bonadio and Nicola Lucchi (eds) Non-Conventional Copyright (Edward Elgar Publishing, Cheltenham, 2018) 455 at 468.

${ }^{191}$ See Section 3.3.3.2: Applicable categories.
} 
registered design protection, ${ }^{192}$ another justification for this more limited compromise from the perspective of the public with respect to the industrial designer, is that there are typically significantly less substitutes available for the consumer for industrial designs, than there are for other copyright protected works, such as for example, books or music. ${ }^{193}$ Moreover, industrial designs typically have a relatively short product life span. ${ }^{194}$

From a naturalist perspective, the creators' of works, such as multisensory virtual designs, should be rewarded exclusory rights for their creativity. The reward is a reflection of society's gratitude for their work. ${ }^{195}$ It is also important that such works be protected from an equal treatment perspective, although the duration of exclusive rights, from an instrumentalist perspective, should not be so long so as to undermine the rapid technological development in this field. ${ }^{196}$

Further research is required to give an intimation of an appropriate term, but certainly, as Graeme Austin observes, giving in entirely to the free culture movement and surrendering too much to the public domain, is adding "Legal insult to technological injury."197

\subsubsection{Usefulness of a "spare parts exception"}

\footnotetext{
${ }^{192}$ See Industrial Property Advisory Committee The Law of Copyright as it Applies in New Zealand to Industrial Designs (Report to the Minister of Justice 1983) at [3.3].

${ }^{193}$ Graeme Austin "Property on the Line: Life on the Frontier between Copyright and the Public Domain (2013) 44 VUWLR 1 at 11.

194 This has been observed by the New Zealand Ministry of Commerce in the past. The Ministry suggested reducing the term of protection to 3 years from industrial application - see Ministry of Commerce Business Policy Division Reform of the Designs Act 1953 and Other Issues Proposed Recommendations (1992) at 19.

${ }^{195}$ Giblin, above n 162, at 198.

${ }^{196}$ Reese, above 167, at 121.

${ }^{197}$ Austin, above n 193, at 2.
} 
The "spare parts exception" has previously been considered in New Zealand. ${ }^{198}$ Informed by the consultations carried out by the Industrial Property Advisory Committee in $1984,{ }^{199}$ the New Zealand Parliament in 1985 responded to the mischief that the "spare parts exception" was introduced to prevent in the United Kingdom, ${ }^{200}$ by reducing the term of protection for “artistic work applied industrially” to 16 years. ${ }^{201}$

Although it may seem like a very substantial reduction, in the case of many industrial designs, anything beyond 16 years is outside the product's lifecycle. As such, under the present copyright system in New Zealand, many industrial designs are provided protection in two markets, namely the primary product market and the secondary replacement parts market, for essentially the duration of their natural economic life. ${ }^{202}$ Despite this being the case, several interviewees thought such a protection is consistent with the normal exploitation of one's work. Legal practitioner ' $\mathrm{O}$ ' stated: "Someone who has spent a lot of time developing a product, for example a car, should be allowed to have a degree of control of the parts that go into that car for spare parts."

This reasoning is consistent with the finding of the European Court of Justice in $A B$ Volvo $v$ Erik Veng Ltd, ${ }^{203}$ which held that a dominant position in the spare parts market by virtue of

\footnotetext{
${ }^{198}$ For an explanation of what the "spare parts exception" is and what it is an exception to, see the discussion in Section 3.3.6.1: Competition and the "spare parts exception".

${ }^{199}$ See (11 October 1984) 458 NZPD 1028.

${ }^{200}$ Namely, the copyright holder's exclusive rights extending into the secondary market of replacement parts, and thus interfering with the public's right to repair.

${ }^{201}$ Mono Pumps (New Zealand) Limited \& Anor v Karinya Industries Limited \& Ors (1986) 1 NZBLC 102, [575] at [582].

${ }^{202}$ A statutory exception for protection of spare parts was suggested as a possible option for reform - see New Zealand Ministry of Commerce Competition Policy and Business Law Division Review of Industrial Property Rights Patents, Trade Marks and Designs (1990) at [22.5].

${ }^{203}$ See $A B$ Volvo v Erik Veng Ltd, above n 91 [1989] 4 CMLR 122.
} 
intellectual property rights alone is not an abuse, but merely the legitimate consequence of exclusory rights. ${ }^{204}$

In Radio Telefis Eireann (RTE) and Independent Television Publications Ltd v Commission of the European Communities, ${ }^{205}$ the court also held that a dominant position in a secondary market by virtue of intellectual property rights alone was not abuse. ${ }^{206}$

Although prima facie this rationale for not having a "spare parts exception" appears solid, it is not without challenge. In fact, the interviewees who provided an opinion on this issue were fairly evenly split. Approximately half of the interviewees believed it was necessary to introduce a "spare parts exception" into New Zealand. It is important for the consumer, explained legal advisor 'L', stating:

If there is no competition, or reduced competition, for spare parts, consumers have to buy their products from the original manufacturer. The original manufacturer can of course charge what they like, sometimes even outside the 16-year period, because people do not realise the protection term is up. I think it stifles competition.

The major counter argument from those who were opposed to having a "spare parts exception" was that the exception would lead to reduction in the quality of spare parts. In some industries, according to those promulgating this argument, this would have catastrophic implications. Legal practitioner 'I' explained:

It is a problem when you get to things like helicopters, aircraft and motor vehicles. So the spare parts look genuine and on the outside they look fine, but, of course, they have not

\footnotetext{
${ }^{204}$ Ibid, at [130].

${ }^{205}$ Case C-241/91 P Radio Telefis Eireann (RTE) and Independent Television Publications Ltd v Commission of the European Communities [1995] FSR 530.

${ }^{206} \mathrm{Ibid}$, at [543].
} 
been made of appropriate materials that have been stress tested, $\mathrm{x}$-ray tested and this and that. There have been some terrible accidents ... in other parts of the world ... particularly with helicopters, where parts have not been made by the original manufacturer.

This is a very real concern, but, of course, this is the reason for product safety standards. If a "spare parts exception" were to be introduced into New Zealand, it would also likely be necessary to introduce additional product safety standards, as well as quality inspection entities and processes to mitigate this risk. Government expenditure on this would need not be so great, however, if instead of being applied carte blanche to everything, the "spare parts exception" was only applicable to industries in which there is an obvious need for it.

A "spare parts exception" should be introduced in New Zealand for motor vehicles, as there is an obvious need for it in this industry. The majority of interviewees that provided an opinion on the matter thought that it was necessary in the motor vehicle industry, because the price of replacement parts for vehicles is often extortionate. "If you crashed a modern car, even a craplooking car and damaged the headlight", pointed out academic 'D', "it would still have a left and right headlight worth $\$ 500$ a pop.” A “spare parts exception” for motor vehicles should therefore ensure car owners have access to affordable replacement parts.

Further investigatory research into specific industries would be useful to determine whether there are other industries in New Zealand that could benefit from a "spare parts exception".

\subsubsection{Mitigating the negative impact of 3D printing technology}

Further advances in 3D printing are likely to revolutionise the process of product development and manufacture. At the same time, however, as noted in Chapter 5, advances in the technology 
will further increase the likelihood of intellectual property infringement. ${ }^{207}$ Academic ' $\mathrm{C}$ ' explained that 3D printing will constitute infringement "if someone scans something without the owner's consent and then prints it."

Academic ' $\mathrm{C}$ ' was of the opinion that "the law would really struggle to protect against this." Legal practitioner ' $\mathrm{M}$ ' was of the opposite opinion, and thought that industrial designers are sufficiently protected "in New Zealand, because of the Copyright Act ..." Although legal practitioner ' $\mathrm{I}$ ' is not as confident that existing law is sufficient to combat the likely threat of 3D printing, they are nevertheless of the opinion that the issue will "probably be easily settled by a piece of landmark case law that will set down some rules, which will serve as a guide". Legal practitioner ' $\mathrm{K}$ ' thought that "the ability to take action for contributory infringement would help.” They explained:

If you have a registered design of a bowl ... it probably would not ... make sense to take legal action against each individual that printed that bowl ... but if someone sells a programme to make a product that is protected by a registered design owned by another party, without having the other party's consent, it would be useful to be able to take legal action against the seller for contributory infringement under the New Zealand Designs Act.

Legal advisor ' $\mathrm{V}$ ' explained that "sometimes you just have to wait for the problem to manifest itself before you actually do anything." They did, however, acknowledge the potential downside of this approach, stating:

There will of course be problems for those that find themselves stuck in the middle of the problem with no way forward. It is kind of like knowing that a particular part of the road

\footnotetext{
${ }^{207}$ See discussion in Section 5.2.3: The impact of 3D printing on the rights of design owners and competition in the market.
} 
is likely to cause accidents, but until people start regularly crashing on the corner, you are not going to do anything about it, because there are other bits of the road that need greater attention.

Although the approach described by legal advisor ' $\mathrm{V}$ ' is effectively the antithesis of proactive action, this is unfortunately the approach that the New Zealand Government is most likely to take, due to limited resources and the presence of other seemingly more imminent issues. Even if legislators are not yet willing to make amendments in response to the threat, industrial design owners may nevertheless be able to take alternative non-legal preventive measures.

To minimise the negative impact of the technology, industrial design owners can "put barriers on downloading 3D designs", a company ' $\mathrm{T}$ ' explained. However, as a legal advisor specialising in intellectual property (legal advisor ' $L$ ') pointed out:

People ... will try to get around them. Like the whole thing with DVD players and region codes ... I do not think it would take people very long to get around technological protection measures on 3D printers.

Although "it is always going to be possible" to do so, as company ' $\mathrm{T}$ ' acknowledged, it is also possible to "make it so that it takes a lot of effort to hack into the designs." In fact, a legal practitioner specialising in intellectual property (legal practitioner ' $O$ ') explained that technological protection measures (TPMs) have proved to be very efficient in preventing illegal activity where there is cooperation between the owners of the device that enables potential infringement and the content owner. So, therefore, in the same way as "they [content owners] had cooperation from the digital media owners ... you [an industrial design owner] would have to have cooperation from the manufacturers of the 3D printing machines." 
A design academic (academic 'D') could already envision the type of TPMs that would likely prove useful in combating design infringement via 3D printers, stating:

There will soon be software that, like other recognition type software, will be able to analyse designs and determine similarity. That is quite doable and probably will happen.

Another design academic (academic ' $\mathrm{C}$ ') explained how such software would potentially be utilised in the future. They stated:

Imagine cloud data files that store MRI type scans of products. So you would put your product through a scanner to get a really detailed 3D map of it and then put that on the database. A database like the big library in America which stores the ISBN book numbers of every book that is written and keeps a copy of it. The scanned product may be a chair and so when someone else uploads another chair, we can do this weird merge thing, where one is blended over top of the other, to determine how similar they are. If there is, say, $70 \%$ similarity, then "sorry, that's going to be an infringement." You then know not to waste time and money actually making the chair.

The problem with databases containing such detailed 3D depictions of industrial designs is that the databases could themselves be used improperly by infringers for the purposes of obtaining and printing the industrial designs of others. Academic ' $\mathrm{C}$ ', however, explained that this risk could be mitigated quite easily by:

Having the computer scramble the data. The scanners at airports made me think of this. The scanning used to be really invasive. You could pretty much see people with their clothes off, so they thought, "well this is probably not cool." So they scrambled it. Now you only see a morphed like figure, but things like guns stick out. So because the data is scrambled, you would not have to worry about others' downloading your design. 
Of course, where there is a will there is a way, so really dedicated hackers will most likely be able to circumvent a more sophisticated TPM, such as the above, as well. That said, the law, as legal practitioner ' $\mathrm{O}$ ' pointed out, will eventually "come into place, making such circumventing illegal."

In the meantime, there is a much simpler way of protecting one's industrial designs from being 3D printed without consent, namely by only rendering images online. Company ' $\mathrm{T}$ ' explained:

When you go on Amazon, for example, you see a screen shot. You are not able to do much with a screen shot. You can do more with a 3D object because there are a lot of gradations and fidelity in 3D objects. Although we pride ourselves on the fact that our representations are actually quite manufacturable, it exposes us to certain dangers. If our entire model is available on a person's browser, they can take that down and probably get a pretty good 3D print of that. So one way to mitigate that is by rendering images that only feel 3D.

Aside from taking basic precautions such as that suggested by company ' $\mathrm{T}$ ', it is also important to bear in mind that it often proves more worthwhile to adapt to technological developments rather than be entirely concerned with finding ways to protect oneself from potential negative ramifications of the technology. A design consultancy firm (company 'A') explained:

It is just about adapting and understanding how people are using goods. My favourite example is Sky TV. They have not adapted to the way people consume media, whereas a lot of other companies have. So they are going down the toilet in the United States and they just ... need to ... change the way that they deliver their service to their customers. Listen to what their customers want and build the technology to do it properly. You still have people downloading torrents. That is still happening, but those people are a bit geekier. All the mainstream people ... are on Netflix and stuff. 
In terms of adapting to 3D printing technology, one way, company ' $\mathrm{T}$ ' suggested, in which people can be deterred from printing industrial designs illegally, is by:

Making it easy enough and cheap enough for people not to do that. So you just need to make it convenient, by, for example, providing better fidelity, or just an easier way to print that is cheap enough.

In the absence of appropriate legal protections, there are nevertheless practical strategies that can be employed such as those suggested above with respect to 3D printing. These may often prove just as useful (if not more so) than legal protections. The aim of the suggestions and recommendations, in terms of both legal and non-legal protection that is provided in this chapter, is appropriate protection for New Zealand industrial designs in light of foreseeable advances in technology. Informed by analysis of competing interests, the recommendations in this chapter constitute original guidance for New Zealand policy and its lawmakers as well industrial design owners.

Valuable insight from designers, design oriented academics and companies, as well as legal practitioners, further contributes to the originality of these recommendations. Some of the recommendation are however, subject to further research. For example, an investigation into contributions of specific industries to public interest, factoring in considerations like speed of innovation in relevant fields, would be useful for making more informed recommendations in terms of industry specific protection terms and permitted exceptions.

The following chapter focuses on appropriate protection for New Zealand industrial designs in China and provides suggestions and recommendations as to both legal and non-legal protection strategies. 


\section{Suggestions and Recommendations in Light of Obstacles New Zealand Industrial Design Owners can Expect to Encounter in China}

Many New Zealand industrial designs are manufactured in China. There are both legal and practical obstacles that New Zealand industrial design owners can expect to encounter in the process of having their designs manufactured. These obstacles are also relevant to New Zealand industrial design owners who choose to sell their finished products in China.

To ensure that their industrial designs are appropriately protected in China it is important for New Zealand industrial design owners to understand that the copyright protection for industrial designs may not be as easily attainable in China as it is in New Zealand. As such, they should also seek to protect their designs in China with a design patent. The design patent however, may, on its own, also prove to be an inappropriate means of protection. One of the major weaknesses of a design patent is that it is granted without a substantive examination being conducted. Therefore, a design patent may later prove to be invalid when challenged. It is thus advisable that New Zealand industrial design owners also employ non-legal protection strategies in China.

One of the major practical obstacles that New Zealand industrial design owners can expect to encounter in China is connected to the difference in culture and the attitude toward copying. Traditionally, intellectual property was not perceived as being subject to individual ownership. As such, unauthorised copying and counterfeiting remains prevalent in parts of China to this day. It is therefore recommended that extra care be taken by New Zealand industrial design owners manufacturing their design in China. The risk of unauthorised copying can be mitigated significantly by having component parts of a design manufactured by different factories in 
different parts of the country. Such a strategy makes it difficult for any one factory to sell unauthorised copies of the complete product out of their backdoor.

In the event that a contracted factory or another Chinese company sell unauthorised copies of their design, New Zealand industrial design owners may find it very difficult to enforce their intellectual property rights simply by writing to the infringers and asking them to stop on the basis that their copyright or design patent rights are being infringed. This is because many Chinese companies do not value intellectual property protection that is not subject to substantive examination. For this reason, it is suggested that New Zealand industrial design owners, who have their rights infringed, utilise the very accessible judicial and administrative bodies in China to enforce their rights.

The best way to avoid the need for enforcement action, is for New Zealand industrial design owners to only go into business with local Chinese companies with whom they have a strong relationship of trust. Although such relationships usually take a long time to build, the time needed can be significantly shortened by leveraging existing relationships of experienced companies with already established operations in China.

Each of the above described legal as well as practical obstacles and the suggestions and recommendations for how they can be overcome are elaborated on further below.

\subsection{Legal Obstacles}

The two main intellectual property mechanisms likely to be utilised by New Zealand businesses for protecting their industrial designs in China are copyright and design patent. This section 
provides an overview of the obstacles likely to be encountered under each of these mechanisms and provides suggestions and recommendations for how the obstacles can be overcome.

\subsubsection{Protecting “works of applied art” under copyright}

Copyright protection may not be as easily attainable for industrial designs, as it is in New Zealand.

"Work of applied art" appears to have a substantially higher qualification threshold than other copyright works in China, ${ }^{1}$ making it analogous to New Zealand's "work of artistic craftsmanship". "It has a similar objective", commented a legal practitioner specialising in intellectual property (legal practitioner ' $\mathrm{M}$ ').

"Works of applied art" in China must contain a substantial degree of artistic merit. ${ }^{3}$ Determining whether or not something has a substantial degree of artistic merit, however, can be somewhat problematic, a legal advisor specialising in intellectual property (legal advisor 'L') pointed out:

I do not think courts and judges are really used to making that sort of call. What exactly is a substantial degree of artistic merit? I think it is really difficult to make a call about whether something has a substantial degree of artistic merit. Art is one of those things that people have different opinions on since it is so subjective. I mean what you think has artistic merit might be completely different to what I think has artistic merit.

\footnotetext{
${ }^{1}$ For discussion of the required threshold - see Section: 4.1.3: Requirements.

${ }^{2}$ For discussion re "work of artistic craftsmanship" - see Section 3.3.3.2.1; and Section 6.1.4.

${ }^{3}$ See discussion in Section 4.1.3: Requirements.
} 
Another legal practitioner specialising in intellectual property (legal practitioner ' $K$ ') was of a similar opinion:

I think it is too subjective with regard to what is considered to be "artistic merit". I think that some modern designs may be viewed by some people as being very artistic and by others as being of no artistic quality at all.

As explained in chapter $4,{ }^{4}$ the reason for the higher threshold for "works of applied art", ${ }^{5}$ can be attributed to the general consensus amongst Chinese courts that a design patent is the appropriate intellectual property mechanism for protecting industrial design in China.

Due to the seemingly higher threshold, copyright protection for industrial designs may be harder to attain in China than it is in New Zealand. As such, New Zealand industrial design owners should also seek to protect their designs in China with a design patent.

\subsubsection{Acquiring a design patent}

Although a design patent is the appropriate mechanism for protecting most industrial designs, New Zealand businesses seeking such protection in China, will find that the Chinese definition of "design" is more restrictive than the New Zealand definition provided in the Designs Act 1953. The New Zealand definition requires features to "appeal to" and be capable of being "judged solely by the eye". ${ }^{6}$ The Chinese definition takes the standard a step further by requiring a design to be "rich in aesthetic appeal". ${ }^{7}$ The restrictive nature of this definition resembles the higher threshold for "works of applied art" in China's Copyright Law. ${ }^{8}$

\footnotetext{
${ }^{4}$ See discussion in Section 4.1.3: Requirements.

${ }^{5} \mathrm{Cf}$ the threshold in New Zealand - see Section 3.3.3.2: Applicable categories.

${ }^{6}$ See Designs Act 1953 (NZ), s 2(1).

${ }^{7}$ See Patent Law of the People's Republic of China 1984 (as amended up to the decision of 27 December 2008, effective as of 1 October 2009), art 2.

${ }^{8}$ See discussion in Section 4.1.3: Requirements.
} 
On the one hand, the restrictive Chinese definition is perhaps justified by the fact that it is a requirement for patent protection, whereas the New Zealand definition of "design" is provided in the registered design system. On the other hand, it must be noted that China does not have a registered design system. The Chinese design patent is essentially the same as a New Zealand registered design. Moreover, as noted above, the high threshold for copyright protection for a "work of applied art" in China reflects the general judicial consensus that design patents are the more appropriate protection mechanism for industrial designs. The high threshold for protection for design patents is thus puzzling.

Academic 'P', however, points out that "although the law has such a requirement, the courts interpret it broadly". To infringe a design patent, the infringing design has to be of the same or similar type as the patented design. ${ }^{9}$ Although this threshold does not appear stringent, it is important to note that it is higher than New Zealand's threshold, which only deems designs to be infringing if they are the same or substantially the same as previously registered designs. ${ }^{10}$

Available statistics suggest that the threshold is also being interpreted generously at the point of registration in China, as a very high number of industrial designs are being granted. The 2016 report prepared by the State Intellectual Property Office of the People's Republic of China (SIPO) showed that a total of 650,000 design patents were granted that year, and the number had risen by $14.3 \%$ from the previous year. ${ }^{11}$ The inconsistency between the law and practice is reflective of a system without a substantive examination requirement.

\footnotetext{
${ }^{9}$ See Jinjiang Qingyang Weiduoli Food Co v Zhangzhou Yueyuan Food Co Supreme People’s Court No 1658 (2010).

${ }^{10}$ See UPL Group Limited v Dux Engineers Limited [1989] 3 NZLR 135 (CA) at 139.

${ }^{11}$ State Intellectual Property Office of the People's Republic of China Intellectual Property Rights Protection in China (2016) at 4.
} 
As such, New Zealand business can expect no great difficulty in obtaining a design patent. However due to the non-substantive nature of the examination at the point of registration, there is a risk that the patent may later prove invalid in the event that it is challenged. ${ }^{12}$

Although there is also no legal requirement for substantive examination pre-registration in New Zealand, as discussed in Chapter 4, intellectual property rights infringement by unauthorised copying is much more prevalent in China than it is in New Zealand. As such, it is advisable that New Zealand industrial design owners, manufacturing their designs and/or selling their products in China, employ non-legal protection strategies as well.

\subsection{Practical Obstacles}

The most significant obstacles for New Zealand industrial design owners in China, is not the letter of the law, but rather have to do with differences in culture with respect to intellectual property in business and among the general public. There are also ongoing issues with enforcement of intellectual property rights. Each of these obstacles is elaborated on and suggestions and recommendations for how these can be overcome are made below.

\subsubsection{Counterfeiting culture}

The most obvious obstacle that New Zealand businesses face with respect to China is the significant difference in culture. In terms of intellectual property, the traditional rationale of the two cultures is very different. New Zealand, on the one hand, has, in accordance with Western tradition, recognised the property rights of individuals ever since being colonised by

\footnotetext{
${ }^{12}$ See discussion in Section 4.2.4: Patent examination. The same observation can also be made with respect to registered designs in New Zealand.
} 
the British Empire. ${ }^{13}$ China, on the other hand, traditionally did not value the property rights of individuals. ${ }^{14}$ Traditionally in China, copying another's work was not considered an infringement of another's intellectual property rights, but, rather, quite the contrary. Precise copying was a sign of admiration and respect for the original work. ${ }^{15}$ Since 1981 , the Chinese Government has endeavoured to harmonise its intellectual property system with that of the Western world. ${ }^{16}$ Despite very substantial and continuing efforts by the central government, counterfeiting is still prevalent in China, as the country is not a homogenous nation. ${ }^{17}$ The economies of many regions have been underpinned by counterfeiting industries, made possible through the legitimate production lines of factories established by multinational companies. ${ }^{18}$ As such, New Zealand businesses seeking to utilise China's manufacturing capabilities run the risk of having their designs counterfeited.

Perhaps the most obvious way to sell in China while minimising the risk of being subject to counterfeiting is to manufacture one's industrial designs outside of China. This strategy is particularly effective if the design is quite complex. When the design is complex, counterfeited replicas are usually very obviously of a much lower quality than the original. Therefore, as a design consultancy firm (company 'A') phrased it, one need not "worry about it. Counterfeit products are just that, they are just counterfeit products." If the complex design is manufactured in a Chinese factory, however, then the owner of the design puts a lot of trust in the Chinese manufacturer. All interviewed companies that had business experience in and/or with China

\footnotetext{
${ }^{13}$ Jack Vowles "Liberal Democracy: Pakeha Political Ideology" (1987) 21(2) NZJH 215 at 219.

${ }^{14}$ Jonathan Ocko "Copying, Culture, and Control: Chinese Intellectual Property Law in Historical Context" (2013) 8(2) Yale J L \& Human 559 at 569.

${ }_{15}$ William Alford To Steal a Book Is an Elegant Offence: Intellectual Property Law in Chinese Civilization (Stanford University Press, California, 1995) at 29.

16 Jane Menzies and others "Intellectual Property, Business and China: Taking a Stand (2013) 18 Deakin L Rev 89 at 106.

17 Peter Yu "Intellectual Property, Economic Development, and the China Puzzle" in Daniel Gervais (ed) Intellectual Property, Trade and Development: Strategies to Optimise Economic Development in a TRIPS Plus Era (Oxford University Press, New York, 2007) 173 at 203.

${ }^{18}$ Gene Tyndall “Counterfeiting and Supply Chains” Supply Chain Digest (online ed, Ohio, 19 June 2007).
} 
emphasised that relationships of trust are very important in China and are generally established over long periods of time.

It may be possible to bypass the extensive period of time required for relationship building by leveraging existing relationships between New Zealand and Chinese companies. If there is no relationship of trust, however, the design owner runs the risk, as company ' $A$ ' explained, of the factories they work with "copying their products and selling them out the back door." For example, in the context of furniture, when chairs are copied, even though they usually look very similar they are not as comfortable. A furniture design company (company ' $\mathrm{H}$ ') explained that this is because "getting the perfect rake on a chair and the perfect sit takes many, many prototypes ... but persons copying ... will try to cut corners". If the designer chooses to utilise a manufacturer in China, the Chinese manufacturer will be provided with the mould for the finished design, and if a relationship of trust has not been established, the design owner runs the risk of the mould being used to make unauthorised copies of the chair, or even being sold on to counterfeiters. This would be very detrimental to the design owner, because, as company ' $\mathrm{H}$ ' pointed out, "if they were to get their hands on the mould, then a lot of that hard work is done."

The detriment would not be so substantial to an original design owner if the Chinese manufacturer handed over their design to counterfeiters in industries where the most important thing is to be first to produce. This is not the case for furniture, particularly the classical furniture industry, but in fast-moving, design-trend industries where designs tend to have much shorter lifecycles, simply being first is a viable strategy. In such industries, the risk of counterfeiting may be worth the lower production cost, because in these industries the more 
important thing is to "have good channels of publication", pointed out a design academic (academic ' $\mathrm{D}$ '), before elaborating:

People will know you did it if you put it out everywhere with your name on it. Then, by the time somebody rips it off, you have already put out the next one.

In industries where designs generally have longer lifecycles, however, the risk may not seem anywhere near as reasonable. Nevertheless, it may still be possible to manufacture in China in such instances, even when a relationship of trust has not been established. A good strategy to employ for New Zealand businesses in such a position is "to hold onto and control the supply chain of critical components", company 'A' explained. A multinational company (company 'F') employs this very strategy in China. It contracts companies in different parts of China to manufacture different parts of its industrial designs, thus making sure that "each company ... has only part of the picture ... and no one company has too many parts."

Such tactics will continue to become less and less necessary as enforcement of intellectual property rights in China improves.

\subsubsection{Enforcement of intellectual property rights}

Overall the statutory law in New Zealand and China as relevant to industrial design protection is substantially similar. ${ }^{19}$ The main differences in legal protection have to do with enforcement. Although the Chinese Government has made great strides in reducing infringement numbers, ${ }^{20}$ there nevertheless appears to be a kind of hierarchy of importance with respect to enforcement, in practice. For example, some Chinese companies do not seem to be particularly concerned

\footnotetext{
${ }^{19}$ For the relevant law in New Zealand - see Chapter 3; For China - See Chapter 4.

${ }^{20}$ See the discussion in Section 4.5: Enforcement.
} 
about respecting intellectual property that has not been subject to substantive examination. A legal practitioner specialising in intellectual property (legal practitioner ' $O$ ') provided the following example:

We wrote to Alibaba and Taobao ... when our client's registered copyright was infringed. They responded by ... effectively saying "it is nice you have copyright, but that is not relevant to the issue, because these rights ... are not valid ... as copyright ... is not subject to examination.

Similarly, utility model and design patents are also less likely to be respected by Chinese companies because, unlike invention patents, they are subject only to a preliminary examination. $^{21}$

Companies that offer similar service to Alibaba outside of China, however, are much more responsive to intellectual property rights that are not subject to substantive examination. Legal practitioner ' $\mathrm{O}$ ' explained:

If you did the same to Trade Me ... in New Zealand ... they would be all over it immediately, and I know from experience ... that the same is true for ... eBay in the United States. When we previously wrote to eBay notifying them about images infringing our client's copyright, those were taken down within 24 hours.

It is noteworthy that in 2017 Alibaba reported substantial recent improvements in its response to claims of intellectual property infringement. ${ }^{22}$ In the second half of $2017,95 \%$ of takedown requests were processed within 24 hours. This represented a $68 \%$ reduction in average processing time compared to $2016 .{ }^{23}$ Moreover, within the same time frame there was a $42 \%$

\footnotetext{
${ }^{21}$ See Patent Law of the People's Republic of China 1984, above $\mathrm{n} 7$, at art 40.

${ }^{22}$ See Alibaba Group Intellectual Property Rights Protection (Annual Report, 2017).

${ }^{23} \mathrm{Ibid}$, at 4.
} 
decline in takedown requests, ${ }^{24}$ indicating a substantial reduction in infringing products. However, this may also be a reflection of the reduction of users' faith in the efficacy of the takedown process.

Although lack of respect for intellectual property rights that have not been the subject of substantive examination can be considered an obstacle for New Zealand businesses, which they are unlikely to face domestically, there may be other ways to enforce their rights. Legal practitioner ' $\mathrm{O}$ ' acknowledged this, stating:

I think if we actually took action through a court or other form of third party intervention $\ldots$ as opposed to ... just writing to them, using their takedown process ... we may have had a better outcome for the client.

Legal enforcement is a significantly more accessible and affordable process in China than it is in New Zealand. ${ }^{25}$ Thus, although it may not be as simple as writing to a company that has facilitated the infringement, businesses have options for initiating legal action through a variety of judicial/administrative bodies. For example, there are special industrial design prosecution centres that have been set up in competitive industries specifically to reduce the duration of the dispute resolution process. ${ }^{26}$ Moreover, if the dispute is not resolvable via a quick process, China has several courts and collegial panels across the country that specialise in dealing with

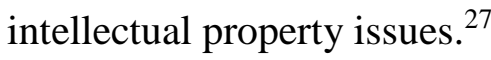

\footnotetext{
${ }^{24}$ Ibid, at 6.

${ }^{25}$ See the discussion in Section 4.5.3: Accessibility to and transparency of the intellectual property legal system. ${ }^{26}$ State Intellectual Property Office of the People's Republic of China Intellectual Property Rights Protection in China (2015) at 22.

${ }^{27}$ Gregory Kolton "Copyright Law and the People's Courts in the People's Republic of China: A Review and Critique of China's Intellectual Property Courts” (1996) 17(1) U Pa J Int'l Econ L 415 at 436.
} 
Outside the dispute resolution bodies, New Zealand industrial design owners can also employ the services of administrative bodies, such as a local Intellectual Property Office. Although it is not possible to seek damages through these administrative bodies, they do have the authority to enforce intellectual property rights. Thus, for example, if one believes their design patent is being infringed, a local Intellectual Property Office can be employed to conduct a raid. Moreover, if evidence of infringement is found in the suspected facility, the local Intellectual Property Office has the power to stop production and impose a fine. ${ }^{28}$

Despite continually improving laws as well as the affordability of and accessibility to a range of enforcement measures, what is perhaps most crucial to ensuring the protection of intellectual property is trust between the parties involved.

\subsubsection{Lasting business relationships}

Traditionally China is a collectivist society. ${ }^{29}$ As such, social networks continue to underpin business arrangements much more significantly than legal agreements. ${ }^{30}$ For this reason, the degree of risk to which New Zealand businesses are likely to be exposed is arguably most dependent on the extent of investment in the personal relationship with their Chinese counterparts.

As well as being focused on social connection, China is also at a stage of transformation from an intellectual property pirate to an intellectual property champion. ${ }^{31}$ Thus, it is foreseeable

\footnotetext{
${ }^{28}$ China IPR "Understanding and Using China's Design Patent" (2015) < www.china-iprhelpdesk.eu> at 6.

${ }^{29}$ Evert Van de Vliert and others "Climato-Economic Imprints on Chinese Collectivism" (2012) 44 J Cross-Cult Psychol 589 at 589.

${ }^{30}$ Thomas Gold, Doug Guthrie and David Wank (eds) Social Connections in China: Institutions Culture and the Changing Nature of Guanxi (Cambridge University Press, Cambridge, 2004) at 15.

${ }^{31} \mathrm{Yu}$, above $\mathrm{n}$ 17, at 202.
} 
that, like other countries before it, such as Singapore and Japan, it is approaching a stage in its economic development where its business focus is very likely to shift from product manufacturer to creator and inventor. ${ }^{32}$ At that stage in their economic development, it is foreseeable that they will become less reliant on foreign businesses for creativity and ingenuity purposes. Therefore, established lasting business relationships are crucial to ensuring that New Zealand businesses are not excluded from successful ventures in coming years.

Ensuring a lasting relationship is first and foremost about selecting "the right partner", company 'A' noted, and as a company that designs children's products (company 'J') pointed out, the right partner is one "who wants your continued involvement."

So, how can New Zealand companies determine which Chinese companies will want their continued involvement? It essentially comes down to two factors. First, the arrangement must be mutually beneficial, and second, it is critical to maintain a good personal relationship with the partner company.

In terms of mutual benefit, the Chinese company will have its own interests. It is important, a multinational company (company 'F') noted, for the New Zealand company to remember that, like themselves, the Chinese company "are investing their time and they want to be sure that they are investing it wisely, if they go ahead."

Aside from meeting each other's needs, the other critical component of a successful partnership with a Chinese company is “Guanxi (关系)”, noted company 'B'. Guanxi (关系) is the notion that social networks underpin Chinese society. "Handshake deals are very important. We need

\footnotetext{
${ }^{32}$ See the discussion in Section 4.5: Enforcement.
} 
to like and trust each other", pointed out company 'B', before emphasising "relationships, trust ... it is really important, it is super important."

Relationships and especially trust is something that is often established over a long period of time. So, as company ' $F$ ' pointed out, "it is very much careful steps, until you really get to know them".

Some companies (especially those in industries where products are usually not expected to have long lifecycles), however, are unlikely to have the luxury of the kind of time required to build trustworthy relationships. The best approach for such companies is to leverage existing relationships. There are three ways this can be done. One way is through government trade bodies. Another is through consultancy firms that specialise in connecting Chinese and New Zealand companies. The third way is through direct referrals/recommendations from other New Zealand companies. Although making connections on the advice of government trade bodies may prove useful, it is likely to be the least fruitful option of the three, because, as company 'B' explained, people in the government "turn over ... they are not always the same people." Thus, the people making the recommendations may not themselves have those personal relationships. Although consultants in firms specialising in connecting Chinese and New Zealand companies are also unlikely to themselves have those personal relationships, they are usually able to provide direct referrals to those that do. Company 'A' explained:

We do that all the time, even if it is just an introduction. Unless there is a conflict of interest then ... that is a lot of the value that we can offer to our clients. That is what it is about.

An introduction to a company that has experience dealing with Chinese companies is indeed very valuable to New Zealand industrial design owners. It is the knowledge of, and insight 
from such companies that informs the original suggestions and recommendations provided in this chapter for how to appropriately protect industrial designs in China.

The suggestions and recommendations in this chapter are of course subject to changes in law and although forward looking, they are nevertheless largely reflective of the existing cultural and economic environment in China.

Future research on developments in China's intellectual property system will be useful in guiding and informing New Zealand industrial owners as China proceeds further down the transformation path from intellectual property pirate, to intellectual property champion. 


\section{Bibliography}

\subsection{Cases}

Ai Lu Mu International Inc v Huizhou Xin Li Da Electronic Tools Ltd Guangzhou Higher People's Court No 45 (2006).

Altoweb Incorporated's Application [2000] IPONZ D1/2000.

AMP Inc v Utilux Pty Ltd [1972] RPC 103 (HL).

Apple Computer v Microsoft Corp 35 F 3d 1435 (9th Cir 1994).

Apple Inc v Samsung Electronics Co Ltd 678 F 3d 1314 (Fed Cir 2012).

Bonz Group (Pty) Ltd v Cooke [1994] 3 NZLR 216.

British Leyland Motor Corp Ltdv Armstrong Patents Co Ltd [1986] 1 All ER 850 (HL).

Bsiri-Barbir v Haarmann \& Reimer Cour de Cassation [2006] 28 ECDR 380.

Burge and others $v$ Swarbrick [2007] HCA 17.

Burrow-Giles Lithographic Co v Sarony 111 US 53 (1884).

Canon Kabushiki Kaisha v Green Cartridge Co Ltd [1997] 2 HKC 1 (HK).

Case 04/18300 L'Oréal SA v Bellure NV [2006] ECDR 16.

Case 237/87 AB Volvo v Erik Veng Ltd [1989] 4 CMLR 122.

Case C04/327HR Lancôme Parfums v Kecofa BV (NL HR 16 June 2006).

Case C-48/09 P Lego Juris A/S v OHIM (Mega Brands Inc intervening) [2010] ETMR 63.

Case C-241/91 P Radio Telefis Eireann (RTE) and Independent Television Publications Ltdv Commission of the European Communities [1995] FSR 530.

Case C-299/99 Philips Electronics NV v Remington Consumer Products Ltd [2002] ECR I5475. 
Case C-310/17 Levola Hengola BV v Smilde Foods BV (Levola Hengola) ECLI:EU:C:2018:899.

Case C-395/16 DOCERAM GmbH v CeramTec GmbH [2018] ECLI 172.

Colgate Palmolive Company v Beecham Group Plc [2002] IPONZ TM Nos 243835 \& 313845.

Computer Assocs Int'l v Altai 982 F 2d 693 (2d Cir 1992).

Comshare Incorporated's Applications 23 IPR 145.

Conrol Pty Ltd v Meco McCallum Pty Ltd, (1996) 34 IPR 157 (FCA).

Coogi Australia Pty Ltd v Hysport International Pty Ltd (1998) 86 FCR 154.

Crocodile International Pte Ltd v Lacoste CIV-2014-485-9300 [2015] NZHC 2432.

DC Comics v Towle 802 F 3d 1012 (9th Cir 2015).

Dreamtech Designs \& Productions Pty Limited v Clownfish Entertainment Limited [2015] NZHC 1143.

Feist Publications Inc v Rural Telephone Service Co Inc 499 US 340 (1991).

Fredco Trading Ltd v Miller (2006) 11 TCLR 751.

George Hensher Limited v Restawile Upholstery (Lancs) Limited [1974] FSR 173.

Godfrey Hirst NZ Ltd v Cavalier Bremworth Ltd [2014] NZCA 418.

Henkel KgaA v Holdfast New Zealand Ltd [2007] 1 NZLR 577.

Huawei v InterDigital Guangdong High People’s Court No 306 (2013).

Hu Sansan v Qiu Haisuo and National Art Museum of China Beijing Higher People's Court No 18 (2001).

Hyde Park Residence Ltd v Yelland News Group Newspapers Ltd [2001] 2 Ch 143 (CA).

Inter IKEA Systems B.V v Taizhou Zhongtian Plastic Co Ltd Shanghai Intermediate People's Court No 187 (2008).

Interlego AGv Keago Company Beijing Higher People's Court No 279 (2002).

Jeanswest Corporation (New Zealand) Limited v G-Star Raw C.V [2015] NZCA 14. 
Jinjiang Qingyang Weiduoli Food Co v Zhangzhou Yueyuan Food Co Supreme People's Court No 1658 (2010).

Meshwerks Inc v Toyota Motor Sales USA Inc 1258 F 3d 1265 (10th Cir 2008).

Mono Pumps (New Zealand) Limited \& Anor v Karinya Industries Limited \& Ors (1986) 1 NZBLC 102.

Muzz Buzz Franchising Pty Ltd v JB Holdings [2013] NZHC 1599.

Navitaire Inc v EasyJet Airline Co Ltd [2004] EWHC 1725.

Nova Productions Ltd v Mazooma Games Ltd \& others and Bell Fruit Games Ltd [2007] EWCA Civ.

OddzOn Products Inc v Oman 924 F 2d 346 (DC Cir 1991).

OKBaby Ltd v Cixi Jiabao Child Product Ltd Beijing Intermediate People's Court No 12293 (2008).

PS Johnson \& Associates Ltd v Bucko Enterprises Ltd [1975] 1 NZLR 311 (SC).

Qualitex Co v Jacobson Prods Co 515 US 159 (1995).

Re Bayer's Design (1907) 24 RPC 65.

Real View LLC v 20-20 Techs Inc 683 F Supp 2d 147 (D Mass 2010).

Reckitt \& Colman Products Ltd v Borden Inc [1990] 1 All ER 873 (HL).

Rice v Fox Broad Co 330 F 3d 1170 (9th Cir 2003).

Salinger v Colting 641 F Supp 2d 250 (SD NY 2009).

Star Athletica LLC v Varsity Brands Inc 137 (S Ct 2017).

Sutton v Bay Masonry Limited unreported, High Court, Tauranga CIV 2003-470-260, 28 May 2004.

Suwa Seikosha’s Design Application [1982] RPC 166.

Taylor Textile Services Auckland Ltd v Taylor [1988] 2 NZLR 1.

The Coca-Cola Company v Frucor Soft Drinks Limited [2013] NZHC 3282. 
Thornton Hall Manufacturing Ltd v Shanton Apparel Ltd (No 2) [1989] 1 NZLR 234.

TrafFix Devices Inc v Marketing Displays Inc 532 US 23 (2001).

Two Pesos v Taco Cabana 505 US 763 (1992).

University of Waikato v Benchmarking Services Ltd (2004) 8 NZBLC 101 (CA).

UPL Group Limited v Dux Engineers Limited [1989] 3 NZLR 135 (CA).

Wal-Mart Stores v Samara Bros 529 US 205 (2000).

Walt Disney Prods v Air Pirates 581 F 2d 751 (9th Cir 1978).

Wham-O MFG Co v Lincoln Industries Ltd [1984] 1 NZLR 641.

Whelan Assocs Inc v Jaslow Dental Lab Inc 797 F 2d 1222 (3d Cir 1986).

Yakult Honsha KK's Trade Mark Application [2001] RPC 39.

Zahn's Application 617 F 2d 261 (CCPA 1980).

\subsection{Legislation}

Anti-monopoly Law of the People's Republic of China 2008 (promulgated by Order No 68).

Commerce Act 1986 (NZ).

Competition Act RSC C 1985 c C-34 (CA).

Copyright Act of 1909 Pub L No 60-349 (US).

Copyright Act 1911 (Imp) 1 \& 2 Geo V c 46.

Copyright Act 1913 (NZ).

Copyright Act 1994 (NZ).

Copyright Amendment Act 1985 (NZ).

Copyright, Designs and Patents Act 1988 (UK).

Copyright Law 17 USC.

Designs Act 1953 (NZ). 
Design Copyright Act 1968 (UK).

Design Regulations 1954 (NZ).

Engraving Copyright Act 1734 (GB) 8 Geo II c 13.

Income Tax Act 2007 (NZ).

Industrial Designs Act 1966 (NZ).

International Copyright Treaties Implementing Rules 1992 (promulgated by Order No 105 of the State Council of People's Republic of China).

Interpretation Act 1999 (NZ).

Models and Busts Act 1798 (GB) 38 Geo III c 71.

Ornamental Designs Act 1842 (UK) 5 \& 6 Vict c 100.

Patents Act 2013 (NZ).

Patents, Designs, and Trade-marks Act 1921 (NZ).

Patent Law 35 USC.

Patent Law of the People's Republic of China 1984 (as amended up to the decision of 27 December 2008, effective as of 1 October 2009).

Patent Law of the People's Republic of China, 1984 (4th draft revision, released on 10 August 2012).

Registered Designs Act 1949 (UK).

Regulation 6/2002 on Community Designs [2002] OJL3/1.

Sculpture Copyright Act 1814 (UK) 54 Geo III c 56.

Testing Laboratory Registration Amendment Act 1988 (NZ).

The Comprehensive and Progressive Agreement for Trans-Pacific Partnership Amendment Act 2018 (NZ).

The Copyright Law of the People's Republic of China 1991 (as amended up to the decision of 26 February 2010, effective as of 1 April 2010). 
The Copyright Law of the People's Republic of China 1991 (3rd draft revision, released on 1 October 2012).

The Major Events Management Act 2007 (NZ).

The People's Republic of China Anti-Unfair Competition Law 2017 (promulgated by Order No 77).

Trade Marks Act 2002 (NZ).

Trans-Pacific Partnership Agreement (CPTPP) Amendment Act 2018 (NZ)

Utility Designs Act 1843 (UK) 6 \& 7 Vict c 65.

\subsection{Treaties}

Agreement on Trade-Related Aspects of Intellectual Property Rights (15 April 1994, entered into force 1 January 1995).

The Berne Convention for the Protection of Literary and Artistic Works (9 September 1886, completed at Paris 1986, as revised at Berlin 1908, Rome 1928, Brussels 1948, Stockholm 1967, Paris 1971, amended 28 September 1979).

Comprehensive and Progressive Agreement for Trans-Pacific Partnership (signed 8 March 2018, entered into force 30 December 2018).

Hague Agreement Concerning the International Deposit of Industrial Designs (6 November 1925, entered into force 1 June 1928, as revised at London 1934, The Hague 1960, Monaco 1961, Stockholm 1967, amended 28 September 1979, revised in Geneva 1999). 
Locarno Agreement Establishing an International Classification for Industrial Designs (as amended on 28 September 1979).

Paris Convention for the Protection of Industrial Property (20 March 1883, as revised at Brussels 1990, Washington 1911, The Hague 1925, London 1934, Lisbon 1958, Stockholm 1967, amended 28 September 1979).

Trans-Pacific Partnership Agreement (signed 4 February 2016, not in force).

\subsection{Reports}

\subsubsection{Parliamentary reports}

(11 October 1984) 458 NZPD 1028.

(23 February 1998) 493 GBPD HL 1057.

\subsubsection{New Zealand Government reports}

Copyright Committee Report Presented to the House of Representatives (NZ, 1959).

Industrial Property Advisory Committee The Law of Copyright as it Applies in New Zealand to Industrial Designs (Report to the Minister of Justice 1983).

Neil Kidd Enterprise and Productivity: Harnessing Competitive Forces (New Zealand Treasury Productivity Paper, 2008). 
Ministry of Business, Innovation \& Employment Copyright and the Creative Sector (2016).

Ministry of Business, Innovation \& Employment Discussion Paper: Review of Section 36 of the Commerce Act and other matters (2019).

Ministry of Business, Innovation and Employment Issues Paper: Review of the Copyright Act 1994 (2018).

Ministry of Business, Innovation and Employment Small Business (2014).

Ministry of Commerce Business Policy Division Reform of the Designs Act 1953 and Other Issues Proposed Recommendations (1992).

Ministry of Foreign Affairs and Trade Comprehensive and Progressive Agreement for TransPacific Partnership: National Interest Analysis (2018).

New Zealand Ministry of Commerce Competition Policy and Business Law Division Review of Industrial Property Rights Patents, Trade Marks and Designs (1990).

\subsubsection{Chinese Government reports}

Guiding Principles and Objectives for Negotiating the Regional Comprehensive Economic Partnership (endorsed by Regional Comprehensive Economic Partnership Ministers 30 August 2012, Negotiations launched 20 November 2012). 
State Council of the People's Republic of China Outline of the National Intellectual Property Strategy (2008).

State Intellectual Property Office of the People's Republic of China Guidelines for Patent Examination (2010).

State Intellectual Property Office of the People's Republic of China Intellectual Property Rights Protection in China (2015).

State Intellectual Property Office of the People's Republic of China Intellectual Property Rights Protection in China (2016).

White Paper on the Status of the Judicial Protection of Intellectual Property Rights in Chinese Courts in 2014 (released by the Supreme People's Court of the People's Republic of China, 2015).

Zhengzhi Wang (ed) China Intellectual Property Index Report (prepared by the China Intellectual Property Index Research Group, 2014).

\subsubsection{Other Reports}

The Advisory Council on Intellectual Property Review of the Designs System (AU, 2015).

Alibaba Group Intellectual Property Rights Protection (Annual Report, 2017). 
Intellectual Property Office Call for evidence: Transitional provisions for repeal of section 52 of the Copyright, Designs and Patents Act 1988 (UK, 2013).

Intellectual Property Office Repeal of Section 52 of the Copyright, Designs and Patents Act 1988: Guidance for affected individuals, organisations and businesses (UK, 2017).

IP Australia The Hague Agreement Concerning the International Registration of Industrial Designs: A cost-benefit analysis for Australia (2018).

Ministry of Law and the Intellectual Property Office of Singapore Final Report Review of Singapore's Registered Designs Regime (2016).

Ministry of Law and the Intellectual Property Office of Singapore Public Consultation on Proposed Changes to Singapore's Registered Designs Regime (2015).

Wijaya Ng and others Opportunities and Challenges in China's 3D Printing Market (prepared by Ipsos Business Consulting 2015).

Special 301 Report (Office of the United States Trade Representative, 2017).

The Hague System for the International Registration of Industrial Designs: Main Features and Advantages (WIPO, Geneva, 2017).

Waitangi Tribunal Ko Aotearoa Tènei: A Report into Claims Concerning New Zealand Law and Policy Affecting Māori Culture and Identity (Wai 262, 2011) vol 1. 
World Intellectual Property Indicators (prepared by World Intellectual Property Organization, 2012).

World Intellectual Property Indicators (prepared by World Intellectual Property Organization, 2017).

World Intellectual Property Organization What is Intellectual Property? (2016).

\subsection{Books and Chapters in Books}

William Alford To Steal a Book Is an Elegant Offence: Intellectual Property Law in Chinese Civilization (Stanford University Press, California, 1995).

Philippe Baechtold, Tomoko Miyamoto and Thomas Henninger "International patent law: Principles, major instruments and institutional aspects" in Daniel Gervais (ed) International Intellectual Property: A Handbook of Contemporary Research (Edward Elgar Publishing Ltd, Cheltenham, 2015) 37.

Vivienne Bath "One Belt, One Road and Chinese Investment" in Lutz-Christian Wolff and Chao Xi (eds) Legal Dimensions of China's Belt and Road Initiative (Wolters Kluwer, Hong Kong, 2016) 165.

Enrico Bonadio and Nicola Lucchi (eds) Non-Conventional Copyright (Edward Elgar Publishing, Cheltenham, 2018). 
Robert Caldini Influence: Science and Practice (5th ed, Pearson Education, New York, 2009).

William Cottrell Furniture of the New Zealand Colonial Era: An Illustrated History 1830 1900 (Reed, Auckland, 2006).

Gerald Cupchik and Michelle Hilscher "Holistic Perspectives on the Design of Experience" in Hendrik Schifferstein and Paul Hekker (eds) Product Experience (Elsevier Ltd, Amsterdam, 2008).

Ian Finch (ed) James and Wells Intellectual Property Law in New Zealand ( $^{\text {rd }}$ ed Thomson Reuters, Wellington, 2017).

Mads Folkmann The Aesthetics of Imagination in Design (MIT Press, Massachusetts, 2013).

Adrian Forty Objects of Desire: Design and Society since 1750 (Thames and Hudson, London, 1986).

Susy Frankel Intellectual Property in New Zealand (2nd ed, Lexis Nexis, Wellington, 2011).

Joep Frens Designing for Rich Interaction: Integrating Form, Interaction, and Function (JFS, Eindhoven, 2006).

Kevin Garnett, Gillian Davies and Gwilym Harbottle Copinger and Skone James on Copyright (16th ed, Sweet \& Maxwell, London, 2011). 
Oliver Gassmann, Angela Beckenbauer and Sascha Friesike Profiting from Innovation in China (Springer-Verlag, Berlin, 2012).

Daniel Gervais The TRIPS Agreement: Drafting History and Analysis (3rd ed, Thomson Reuters, London, 2008).

Rebecca Giblin and Kimberlee Weatherall (eds) What if we could reimagine copyright? (ANU Press, Australia, 2017).

Thomas Gold, Doug Guthrie and David Wank (eds) Social Connections in China: Institutions Culture and the Changing Nature of Guanxi (Cambridge University Press, Cambridge, 2004) at 15 .

Paul Hekkert and Helmut Leder "Product Aesthetics" in Hendrik Schifferstein and Paul Hekker (eds) Product Experience (Elsevier Ltd, Amsterdam, 2008).

Martin Howe, James St Ville and Ashton Chantrielle Russell-Clarke and Howe on Industrial Designs (9th ed, Sweet \& Maxwell, London, 2016).

Tim Ingold The Perception of the Environment: Essays on Livelihood, Dwelling and Skill (Routledge, Abingdon, 2000).

Anna Kingsbury Intellectual Property Law in New Zealand (Wolters Kluwer, The Netherlands, 2017) at 23. 
Carolyn Korsmeyer Making Sense of Taste: Food and Philosophy (Cornell University Press, New York, 1999).

Hugh Laddie, Peter Prescott and Mary Vitoria The Modern Law of Copyright and Designs (3rd ed, Butterworths, London, 2000) vol 1.

Jessica Lai Indigenous Cultural Heritage and Intellectual Property Rights: Learning from the New Zealand Experience (Springer, London, 2014).

Greg Lastowka "Copyright Law and Video Games: A Brief History of an Interactive Medium" in Matthew David and Debora Halbert (eds) The SAGE Handbook of Intellectual Property (SAGE Publications, London, 2014) 495.

Stephen LaValle Virtual Reality (Cambridge University Press, Cambridge, 2019).

Jyh-An Lee "The New Silk Road to Global IP Landscape" in Lutz-Christian Wolff and Chao Xi (eds) Legal Dimensions of China's Belt and Road Initiative (Wolters Kluwer, Hong Kong, 2016) 417.

Guangjie Li Revisiting China's Competition Law and its Interaction with Intellectual Property Rights (Nomos Verlag, Germany, 2018).

Pamela Maykut and Richard Morehouse Beginning Qualitative Research: A Philosophical and Practical Guide (RoutledgeFalmer, London, 1994). 
Craig Mende and Belinda Isaac "When Copyright and Trademark Rights Overlap" in Neil Wilkof and Shamnad Basheer (eds) Overlapping Intellectual Property Rights (Oxford University Press, Oxford, 2012) 137.

David Musker "The Overlap between Patent and Design Protection" in Neil Wilkof and Shamnad Basheer (eds) Overlapping Intellectual Property Rights (Oxford University Press, Oxford, 2012) 23.

Alan Nemes and Anna Carboni “Overlapping Rights in Designs, Trademarks and Trade Dress" in Neil Wilkof and Shamnad Basheer (eds) Overlapping Intellectual Property Rights (Oxford University Press, Oxford, 2012) 251.

Robert Nisbett The geography of thought: How Asians and Westerners think differently... and why (The Free Press, New York, 2003).

Plato Phaedo (385 BCE) (translated ed: H Tredennick (translator) in H Tarrant (ed) The Last Days of Socrates (Penguin Classics, Harmondsworth (Middlesex, 1954)).

Kanwal Puri Industrial Design Law in Australia and New Zealand (Butterworths, Melbourne, 1986).

Sam Ricketson and Jane Ginsburg "The Berne Convention: Historical and institutional aspects" in Daniel Gervais (ed) International Intellectual Property: A Handbook of Contemporary Research (Edward Elgar Publishing Ltd, Cheltenham, 2015). 
Sam Ricketson and Uma Suthersanen "The Design/Copyright Overlap: Is There a Resolution?” in Neil Wilkof and Shamnad Basheer (eds) Overlapping Intellectual Property Rights (Oxford University Press, Oxford, 2012) 159 at 160.

Hendrik Schifferstein and Charles Spence "Multisensory Product Experience" in Hendrik Schifferstein and Paul Hekker (eds) Product Experience (Elsevier Ltd, Amsterdam, 2008) 133.

Brad Sherman and Lionel Bently The Making of Modern Intellectual Property Law: The British Experience, 1760 - 1911 (Cambridge University Press, Cambridge, 1999).

Michael Smythe New Zealand by Design: A History of New Zealand Product Design (Godwit, Auckland, 2011).

Marieke Sonneveld and Hendrik Schifferstein "The Tactual Experience of Objects" in Hendrik Schifferstein and Paul Hekker (eds) Product Experience (Elsevier Ltd, Amsterdam, 2008) 41.

Jörg Strübing "Research as Pragmatic Problem-solving: The Pragmatist Roots of Empiricallygrounded Theorizing" in Anthony Bryant and Kathy Charmaz (eds) The Sage Handbook of Grounded Theory (Sage Publications, London, 2007).

Paul Sumpter Intellectual Property Law: Principles in Practice (2nd ed, CCH New Zealand Limited, Auckland, 2013).

Barbara Thayer-Bacon "Pragmatism" in Penelope Peterson, Eva Baker and Barry McGaw (eds) International Encyclopaedia of Education (3rd ed, Elsevier Ltd, Philadelphia, 2010) 86. 
Thorstein Veblen The Theory of the Leisure Class: An Economic Study of Institutions (Unwin, London, 1970).

Alfred Whitehead The Interpretation of Science (Bobbs-Merrill, Indiana, 1961).

Kim Williams, Jennifer Laing and Warwick (eds) Fashion, Design and Events (Routledge, Oxfordshire, 2014).

Peter Yu "Intellectual Property, Economic Development, and the China Puzzle" in Daniel Gervais (ed) Intellectual Property, Trade and Development: Strategies to Optimise Economic Development in a TRIPS Plus Era (Oxford University Press, New York, 2007) 173.

\subsection{Journal Articles}

Orit Afori "Reconceptualising Property in Designs" (2008) 25 Cardozo Arts \& Ent L J 1105.

John Allison and Lianlian Lin "The Evolution of Chinese Attitudes toward Property Rights in Invention and Discovery” (1999) 20 U Pa J Int'l Econ L 735.

Graeme Austin "Copyright's Modest Ontology - Theory and Pragmatism in Eldred v Ashcroft" (2003) 16 Can JL \& Jurisprudence 163.

Graeme Austin "Property on the Line: Life on the Frontier between Copyright and the Public Domain (2013) 44 VUWLR 1. 
Lloyd Austin “Accounting for intangible assets" (2007) 9 University of Auckland Business Review 63.

Shyamkrishna Balganesh "The Pragmatic Incrementalism of Common Law Intellectual Property" (2010) 63 Vand L Rev 1543.

Judith Banister "Open Government: From Crown Copyright to the Creative Commons and Culture Change” (2011) 34(3) UNSW L J 1080.

Paula Baron "Where art meets science beauty meets utility: the strange world of industrial design protection" (1999) 18 Tasm U L Rev 194.

Rob Batty "Shape trade marks" (2014) NZLJ 133.

Rob Batty "There Goes My Outfit: Copyright in the Fashion Industry in Australia and New Zealand" (2009) 15 NZBLQ 8.

Claudia Bickmann "The Idea of a Highest Divine Principle - Founding Reason and Spirituality" (2012) 3 Religions 1025.

C D Black and M J Baker "Success through Design” (1987) 8 Design Studies 207.

Peter Bloch "Seeking the Ideal Form: Product Design and Consumer Response" (1995) 59 J Mark 16. 
James Bohman "How to Make a Social Science Practical: Pragmatism, Critical Social Science and Multiperspectival Theory" (2002) 31 Millen J Int Stud 499.

F Boselie "The golden section has no special aesthetic attractivity" (1992) 10 ART 1.

Christopher Buccafusco “A Theory of Copyright Authorship” (2016) 102 Va L Rev 1129.

Christopher Buccafusco "Making Sense of Intellectual Property Law” (2012) 97 Cornell L Rev 501.

Christopher Buccafusco, Mark Lemley and Jonathan Masur "Intelligent Design" (2018) 68 Duke LJ 75.

Erin Campbell “Artisans, Artists and Intellectuals” (2000) 23 Art History 622.

Pat Chew "The Rule of Law: China's Scepticism and the Rule of People" (2005) 20 Ohio St J on Disp Resol 43.

Elli Cho "Copyright of Trade Dress toward IP Protection of Multisensory Effect Designs for Immersive Virtual Environments" (2015) 33 Cardozo Arts \& Ent L J 801.

Eugénie Coche "Heks'nkass or the "fiftyshades of taste" explained by the CJEU through EU copyright law" (2019) 41 EIPR 173.

Wayne Condon and Richard Hoad "New Design Laws” (2004) 42 J L Soc’y NSW 52. 
Thomas Cotter "Legal Pragmatism and the Law and Economics Movement" (1996) 84 Geo L J 2071.

John Cross and Peter Yu "Competition Law and Copyright Misuse" (2008) 56 Drake L Rev 427.

Jason Du Mont and Mark Janis "Virtual Designs” (2013) 17 Stan Tech L Rev 107.

R S Edwards "Social and Economic Aspects of Industrial Design” (1948) 97 JRSA 25.

Brian Fitzgerald "Theoretical Underpinning of Intellectual Property: 'I Am a Pragmatist but Theory Is My Rhetoric"” (2003) 16 Can J L \& Jurisprudence 179.

Susy Frankel “The Copyright and Privacy Nexus” (2005) 36 VUWLR 507.

William Fryer "International Industrial Design Protection Improvement: The Hague Agreement Revision” (1994) 2 U Balt Intell Prop L J 37.

Raymond Gabriel "The Patent Revolution: Proposed Reforms in Chinese Intellectual Property Law, Policy and Practice Are the Latest Step to Bolster Patent Protection in China" (2008) 9 APLPJ 323.

G Gemser and M A Leenders "How Integrating Industrial Designs in the Product Development Process Impacts Company Performance” (2001) 18 J Prod Innov Manag 28. 
Wendy Gordon “A Property Right in Self-Expression: Equality and Individualism in the Natural Law of Intellectual Property (1993) 102 Yale LJ 1533.

Karl Grammer and Randy Thornhill "Human (Homo sapiens) facial attractiveness and sexual selection: The role of symmetry and averageness" (1994) 108 J Comp Psychol 233.

Christine Greenhalgh and Mark Rogers "The value of intellectual property rights to firms and society” (2007) 23 Oxf Rev Econ Policy 541.

Thomas Grey “Freestanding Legal Pragmatism” (1997) 18 Cardozo L Rev 21.

Peter Groves “Design Protection for Spare Parts” (2005) BLR 291.

Liang Guo "Product Design and Financial Performance” (2010) 1 Design Management Journal 5 .

J H Hertenstein, M B Platt and D R Brown "Valuing Design: Enhancing Corporate Performance through Design Effectiveness" (2001) 12 Design Management Journal 10.

Rachel Herz and Jonathan Schooler "A naturalistic study of autobiographical memories evoked by olfactory and visual cues: testing the Proustian hypothesis" (2002) 115 Am J Psychol 21.

Kenneth Himma "The Justification of Intellectual Property: Contemporary Philosophical Disputes” (2008) 59 JASIST 1143. 
Justin Hughes “The Philosophy of Intellectual Property” (1988) 77 Geo L J 287.

Dan Hunter and Suzannah Wood "The Laws of Design in the Age of Mechanical Reproduction" (2016) 37 Adel L Rev 403.

T Jacobson and L Höfel "Descriptive and evaluative judgement process: Behavioral and electrophysiological indices of processing symmetry and aesthetics" (2003) 3 CABN 289.

Andrew Jamieson and Amanda Burritt "Ancient Coins: Heads and Tales from Antique Lands (2011) 46 Agora 51.

Yuran Jin and Jiangnan Yu "Research on 3D Printing in China: A Review" (2016) 3 IJRSSET 1.

Elizabeth Judge and Daniel Gervais "Of Silos and Constellations: Comparing Notions of Originality in Copyright Law” (2009) 27 Cardozo Arts \& Ent L J 375.

Shahabeddin Khalighy and others "Quantifying the qualities of aesthetics in product design using eye-tracking technology” (2015) 49 Int J Ind Ergon 31.

Sungho Kim and others "Learning from Successes and Failures of Registration of Patent Applications Based on Physical Ergonomics Research” (2015) 34 J Ergon Soc Korea 455.

Anna Kingsbury "International harmonisation of designs law: the case for diversity” (2010) 32 EIPR 382. 
Gregory Kolton “Copyright Law and the People's Courts in the People's Republic of China: A Review and Critique of China's Intellectual Property Courts" (1996) 17 U Pa J Int'1 Econ L 415.

Stan Liebowitz “A Critique of Copyright Criticisms” (2015) 22 Geo Mason L Rev 943.

Yaonan Lin and Ching Lai "A Study of the Attitudes of Chinese Consumers to Aesthetic Product Designs" (2010) 27 IJM 177.

Benjamin Liu “Chinese Patents as Copyrights” (2012) 34 Campbell L Rev 686.

Deming Liu "Now the Wolf Has Indeed Come! Perspective on the Patent Protection of Biotechnology Inventions in China (2005) 53 Am J Comp L 207.

Paul Locher, Kees Overbeeke and Pieter Stappers "Spatial balance of color triads in the abstract art of Piet Mondrian” (2005) 34 Perception 169.

Francis Maher “Common Sense and Law” (1972) 8 Melb U L Rev 587.

Matteo Mancinella “Copyright Subject Matter and a Light for Designers' Rights” (2012) 29 Santa Clara Computer \& High Tech L J 523.

Jonathan Manè-Wheoki "The Resurgence of Māori Art: Conflicts and Continuities in the Eighties" (1995) 7 Contemp Pac 1. 
S M Mead "The Origins of Maori Art: Polynesian or Chinese?” (1975) 45 Oceania 173.

Jane Menzies and others "Intellectual Property, Business and China: Taking a Stand" (2013) 18 Deakin L Rev 89.

Bryan Mercurio "The Protection and Enforcement of Intellectual Property in China since Accession to the WTO: Progress and Retreat" (2012) 1 China Perspect 23.

Mary Miller "Copyrighting the Usful Art of Couture: Expanding Intellectual Property Protection for Fashion Designs (2014) 55 Wm \& Mary L Rev 1617.

Nettie Mills "Intellectual Property for Fashion Design: An Overview of Existing Law and a Look Toward Proposed Legislative Changes” (2008) 5 Shidler J L Com \& Tech 1.

Gu Minkang “Anti-Abuse of Intellectual Property Rights under the Anti-Monopoly Law: China’s Approaches” (2015) 10 FLC 488.

Ken Moon “A Functional View of Copyright, Designs and Patents” (1975) 8 VUWLR 300.

Adam Moore "Intellectual Property: Theory, Privilege, and Pragmatism" (2003) 16 Can J L \& Jurisprudence 191 .

George Newman and Paul Bloom "Art and Authenticity: The Importance of Originals in Judgments of Value" (2012) 141 J Exp Psychol Gen 558. 
Cathy Nijman "Ascertaining the Meaning of Legislation - A Question of Context" (2007) 38 VUWLR 629.

Jonathan Ocko "Copying, Culture, and Control: Chinese Intellectual Property Law in Historical Context” (2013) 8 Yale J L \& Human 559.

Noreen O’Leary “Keeping up with the Jiangs” (2007) 48 Brandweek 14.

Richard Ormerod “The History and Ideas of Pragmatism” (2006) 57 J Oper Res Soc 892.

Richard Posner "Legal Pragmatism” (2004) 35 Metaphilosophy 147.

Veronique Pouillard “The Milton Case (1955 - 1962): Defending the Intellectual Property Rights of Haute Couture in the United States" (2017) 30 Journal of Design History 356.

Margaret Radin "Reconsidering the Rule of Law” (1989) 69 Bost U L Rev 781.

Kal Raustiala and Christopher Sprigman "The Piracy and Paradox: Innovation and Intellectual Property in Fashion Design" (2006) 92 VA L Rev 1687.

Jason Rawkins "Copyright - designs - British Leyland spare parts defence (1997) 19 EIPR 674.

R Reber, N Schwarz and P Winkielman "Processing fluency and aesthetic pleasure: Is beauty in the perceiver's processing experience?" (2004) 8 PSPR 364. 
Michael Risch "Functionality and Graphical User Interface Design Patents" (2013) 17 Stand Tech L Rev 53.

Adam Rosman "Visualising the Law: Using Charts, Diagrams, and Other Images to Improve Legal Briefs" (2013) J Legal Educ 70.

Charles Ross "Designs on China: Visions Ancient and Modern" (2008) 1 Personal View 112.

Eric Setliff “Copyright and Industrial Design: An 'Alternative Design’ Alternative” (2007) 30 Colum J L \& Arts 49.

Haien Shen and Xiaohong Wen "The Reform of the Chinese Intellectual Property Trial System" (2016) 5 GJCL 68

Wei Shi "Cultural Perplexity in Intellectual Property: Is Stealing a Book an Elegant Offence? (2006) 32 NCJ Int'l L \& Com Reg 1.

Gregory Sidak “The Meaning of FRAND, Part I: Royalties” (2013) 9 JCL \& E 931

Steven Smith “The Pursuit of Pragmatism” (1990) 100 Yale L J 409.

Rachel Stigler "Ooey GUI: The Messy Protection of Graphical User Interfaces" (2014) 12 Nw J Tech \& Intell Prop 215. 
Robert Summers "Pragmatic Instrumentalism in Twentieth Century American Legal Thought - A Synthesis and Critique of Our Dominant General Theory about Law and Its Use" (1981) 66 Cornell L Rev 861.

Matt Sumpter "IP and Competition Law: Friends or Foes?” (2010) 6 NZIPJ 702.

Chang Tan and Chengcheng Li "Influence of 3D Printing on Industrial Design" (2017) 75 ACSR 279.

Andrew Tettenborn "Copyright and Spare Parts: Judicial Legislation in a Good Cause" (1986) 45 Cambridge LJ 216.

Evert Van de Vliert and others "Climato-Economic Imprints on Chinese Collectivism” (2012) 44 J Cross-Cult Psychol 589.

Drew Voth, Brian Park and Nathan Brunette "Apportionment of Intellectual Property Value: Where Economic Theory Meets Legal Practice (2013) 71 Fed Law 73.

Jack Vowles “Liberal Democracy: Pakeha Political Ideology” (1987) 21 NZJH 215.

Pania Waaka "Hei tiki and issues of representation within contemporary Māori arts" (2007) 1 MAI Rev 156.

Mark Walker "Big and Technological Unemployment: Chicken Little Versus the Economists" (2014) 23 JET 5. 
Suzi Wereta "Engaging with Māori Art and Identity: A Conversation with Māori Artists in Otepoti” (2007) 1 MAI Rev 191.

Geoffrey Willard “An Examination of China’s Emerging Intellectual Property Regime: Historical Underpinnings, the Current System and Prospects for the Future" (1996) 6 Ind Int'1 \& Comp L Rev 411.

Jeffrey Wilson "Mega-Regional Trade Deals in the Asia-Pacific: Choosing between the TPP and RCEP?” (2015) 45 J Contemp Asia 345.

Verner Worm and Rajesh Kumar "Pragmatism versus Idealism: Understanding the Negotiating Practices in China and India” (2014) 56 TIBR 519.

Hong Xue "A User-Unfriendly Draft: 3rd Revision of the Chinese Copyright Law" (2012) 7 JICLT 350.

Wu Yao and Jae-Hwan Lee "Aesthetics Research of Chinese Traditional Lamps and Lanterns Using Product Semantics” (2011) 24 KSDS 437.

Lang Ye "Several Inspirations from Traditional Chinese Aesthetics" (2010) 2 Procedia Soc Behav Sci 7556.

Peter Yu “Five Oft-repeated Questions About China's Recent Rise as a Patent Power" (2013) Cardozo L Rev 78. 
Peter Yu "When the Chinese Intellectual Property System Hits 35" (2018) 8 QMJIP 3.

Zhou Yunchuan "Protection of Copyright in Applied Art" (2013) 4 CPT 71.

Mark Zhai "The Chinese Utility Model Patent Is Destroying Innovation in China" (2011) 39 AIPLA Q J 413 at 423.

\subsection{Conference and Seminar Papers}

Stéphanou Angélique "An integrated computational approach for the design of patient-specific virtual tumours" (paper presented to New Mathematical and Computational Problems Involved in Cell Motility, Morphogenesis and Pattern Formation Seminar, Cambridge, 7 December 2015).

Michael Berrell and Jeff Wrathall "Changing Attitudes to Intellectual Property Rights in China: The Nexus between Chinese Culture and the Rule of Law" (paper presented to the Conference of the Association for Chinese Economics Studies, Melbourne, 2003).

Jonathan Cagan and Craig Vogel "Understanding and Protecting Value in New Product

Development" (paper presented to the International Conference on Engineering Design, Stockholm, August 2003).

Darwin Caldwell, Suzanne Lawther and Andrew Wardle "Tactile perception and its application to the design of multi-modal cutaneous feedback systems" (paper presented to International Conference on Robotics and Automation, Minnesota, April 1996). 
Peter Challenor "Experimental Design for Inverse Modelling: From Real to Virtual and Back" (paper presented to UQ for Inverse Problems in Complex Systems Seminar, Cambridge, 11 April 2018).

\subsection{Internet Materials}

“Apply for a Design” New Zealand Intellectual Property Office <www.iponz.govt.nz>.

"Are Efforts to Extend Patent and Copyright Laws Good for Business or Good for Society?" (2001) Wharton <www.knowledge.wharton.upenn.edu>.

China IPR "Roadmap for Intellectual Property Protection in China" (2009) <www.chinaiprhelpdesk.eu>.

China IPR "Understanding and Using China's Design Patent" (2015) <www.chinaiprhelpdesk.eu>.

Commerce Commission New Zealand “Children's Toys: A Guide to Complying with the Product Safety Standard" (2009) <www.comcom.govt.nz>.

Paul Cozens "Designed features can make cities safer, but getting it wrong can be plain frightening" (2018) The Conversation <www.theconversation.com>. 
Collin Dunn "David Trubridge: Designing with Morality" (9 December 2005) Treehugger <www.treehugger.com>.

Charles Feng and Paul Ranjard "Final Draft of Proposed PRC Copyright Law Amendment Released by NCAC” (2013) Wan Hui Da <http://www.wanhuida.com>.

“Examination Process" New Zealand Intellectual Property Office <www.iponz.govt.nz>.

"Fact Sheet Design Searching” (2015) European IPR Helpdesk <www.iprhelpdesk.eu>.

"Hague Express” World Intellectual Property Organisation <www.wipo.int>.

Ian Hunter "Manufacturing" (11 March 2010) Te Ara the Encyclopedia of New Zealand <www.teara.govt.nz>.

Avery Mann "The Hipster Ideals: If Everyone Is a Hipster Can Anyone Be a Hipster" (31 October 2016) Odyssey <www.theodysseyonline.com>.

Gareth May "Fifth Sense: The next stage of VR is total sensory immersion: How will VR expand from audio and visual to incorporate the other senses?" (2017) Wareable <www.wareable.com>.

Lucas Osborn “Intellectual Property’s Digital Future” (2014) Social Science Research Network $<$ ssrn.com>. 
Eleonora Rosati “The AG Opinion in Levola Hengelo: more questions than answers?" (25 July 2018) The IPKat <www.ipkitten.blogspot.com>.

Te Ahukaramū Charles Royal "Māori" (8 February 2005) Te Ara the Encyclopedia of New Zealand <www.teara.govt.nz>.

Skye Rytenskild “A Sustainable Beauty: David Trubridge's Holistic Approach to Design” (14 June 2016) Decor Design <www.decordesignshow.com>.

"Search for Existing Designs" (2018) Intellectual Property of New Zealand <www.iponz.govt.nz>.

Elizabeth Segran "Your H\&M Addiction is Wreaking Havoc on the Environment. Here's how to break it" Fast Company (2019) <www.fastcompany.com>.

Nancy Swarbrick "Creative life - Design and fashion" (8 February 2005) Te Ara the Encyclopedia of New Zealand <www.teara.govt.nz>.

Bai Wei and Zhang Bo "China: Comments on Multi-Protection of Works of Applied Art" (2018) Mondaq <www.mondaq.com>.

Ding Xianjie and Steven Yao Tang Lei "Protecting of Works of Applied Art under Chinese Judicial Practice" (2012) China Law Insight <www.chinalawinsight.com>. 
Cao Yin "China negotiates to join Hague System protecting industrial design patents" (2019)

China Daily <www.chinadaily.com>.

\subsection{Other}

Rana Ansari and others Augmented and virtual reality: emerging legal implications of the “final platform” (white paper prepared by Reed Smith LLP 2017).

Compilation of the Replies to the Questionnaire on Graphical User Interface (GUI), Icon and Typeface/Type Font Designs SCT/36/2 REV 27 January 2017 (document prepared for the Standing Committee on the Law of Trademarks, Industrial Design and Geographical Indications).

"English Oxford Living Dictionaries" (2017) Oxford University Press $<$ https://en.oxforddictionaries.com>.

Betsy Mason "Virtual reality has a motion sickness problem" Science News Magazine of the Society for Science \& the Public (online ed, Washington, 7 March 2017).

Colum Murphy "European Car-Parts Makers Support China Moves on Spare Parts; Firms Approve of Efforts to Loosen Auto Makers' Grip on Spare Parts" Wall Street Journal (online ed, New York, 9 September 2014).

Alice Rawsthorn "Designers Versus Inventors" The New York Times (online ed, New York, 21 April 2013). 
Brian Solomon "Facebook Buys Oculus, Virtual Reality Gaming Startup, for \$2 Billion" Forbes (online ed, New York, 25 March 2014).

Gene Tyndall "Counterfeiting and Supply Chains" Supply Chain Digest (online ed, Ohio, 19 June 2007). 